\author{
UNIVERSIDADE DE SÃO PAULO \\ FACULDADE DE FILOSOFIA, LETRAS E CIÊNCIAS HUMANAS \\ Departamento dE GEOGRAFIA \\ Programa de Pós-GraduaçÃo em Geografia Humana
}

\title{
Representações do espaço geográfico: mapas dasimétricos, anamorfoses e modelização gráfica
}


UNIVERSIDADE DE SÃo PAULO

FACULDADE DE FILOSOFIA, LETRAS E CIÊNCIAS HUMANAS

DEPARTAMENTO DE GEOGRAFIA

Programa de Pós-Graduação em Geografia Humana

\section{Representações do espaço geográfico: mapas dasimétricos, anamorfoses e modelização gráfica}

Eduardo Dutenkefer

Dissertação apresentada ao Programa de Pós-Graduação em Geografia Humana, do Departamento de Geografia da Faculdade de Filosofia, Letras e Ciências Humanas da Universidade de São Paulo, para obtenção do título de Mestre em Geografia.

Orientador: Prof. Dr. Hervé Émilien René Théry 
Para Mari e Vini 


\section{AGRADECIMENTOS}

Ao meu orientador, Prof. Dr. Hervé Théry, pela orientação, incentivo e discussões ao longo desta jornada;

Às professoras Diana Sarita Hamburger e Fernanda Padovesi Fonseca, pelas sugestões e orientações no exame de qualificação, bem como, em discussões, indicações bibliográficas e, interlocutoras que foram desta pesquisa;

Ao professor Jaime Tadeu Oliva, pelos incentivos e discussões epistemológicas em Geografia;

À professora Eliane Kuvasney, pelo incentivo e ajuda na revisão final;

Aos amigos e mestres Arlete Ohata, Benjamin Capellari, Diana Sarita Hamburger, Eliane Kuvasney, Fernanda Padovesi Fonseca, Jaime Tadeu Oliva, José Pereira de Queiroz Neto, Ricardo Mendes Antas Júnior, que contribuíram para a minha formação de geógrafo e incentivaram o início, o durante e a conclusão deste mestrado;

Aos amigos do grupo de trabalho de mestrandos do Hervé, André Nagy, Júlio Hato, Alexandre Gori, Aniel, Daniel, Guilherme, Hilda, Mateus, Rovaine e Mitsuko (In memoriam), pelas discussões, sugestões, estudos e apoio;

Aos amigos de trabalho do LabGeo da Procuradoria Geral do Estado, Ana, Arlete, Daniela Tobias, Fausto, João, Leandro, Mario, Pablo, Rafael, Rosangela, Santiago, Vania e Vivi, pelo incentivo e apoio em todo o percurso. 


\section{SUMÁRIO}

ÍNDICE DE MAPAS

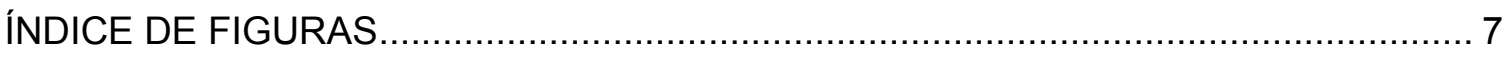

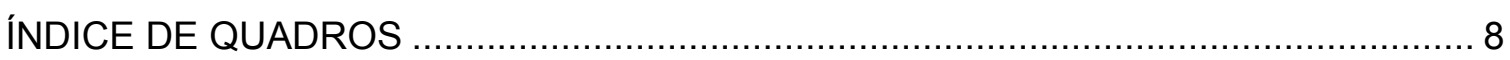

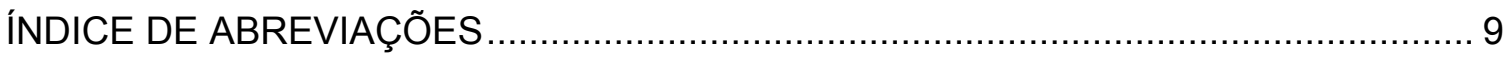

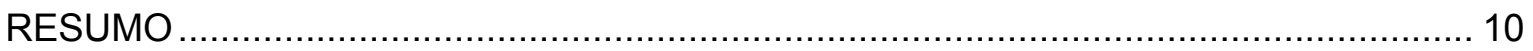

ABSTRACT

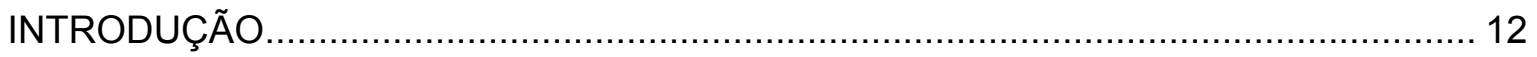

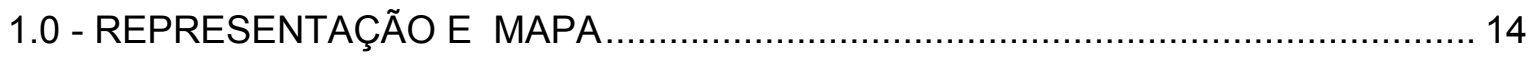

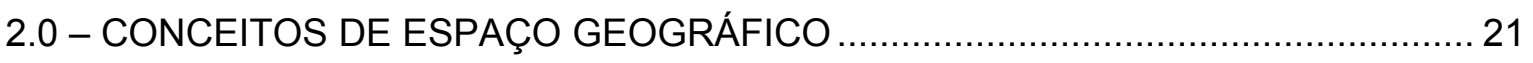

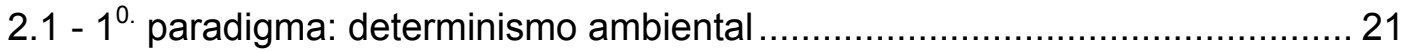

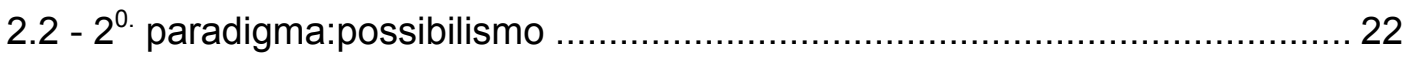

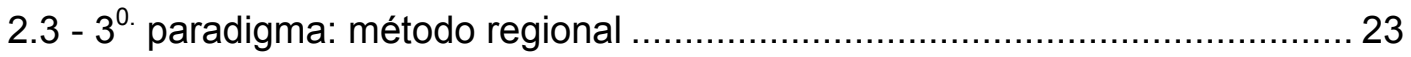

2.4 - Um quarto paradigma? A Região como classe de áreas ........................... 25

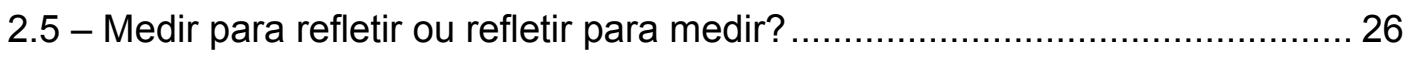

2.6 - Um quinto paradigma? Organização Espacial ........................................... 27

2.7 - Outras concepções de espaço geográfico ……………………………..... 30

3.0 - O MAPA, A COREMÁTICA, O URBANO E A DENSIDADE .................................. 34

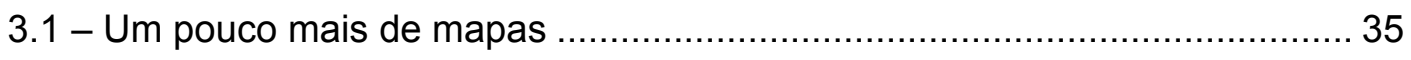

3.2 - A modelização gráfica - coremática .......................................................... 40

3.3 - O urbano e a sua densidade .................................................................. 41

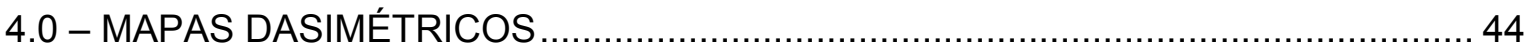

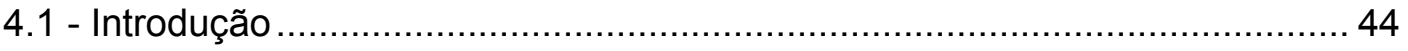

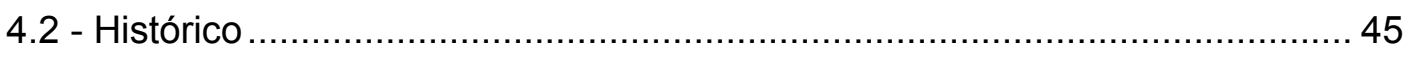

4.3 - A Técnica dasimétrica............................................................................ 50

4.4 - Aplicação da técnica dasimétrica: a densidade Urbana da RMSP .............. 52

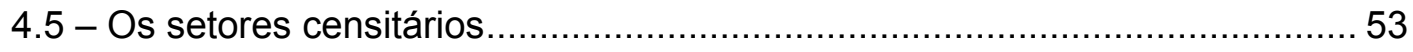


4.6 - "Mapa de Uso e Ocupação do Solo da RMSP" ........................................... 54

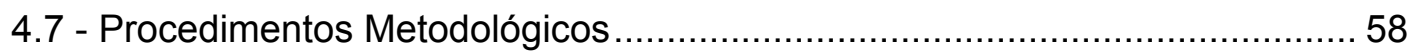

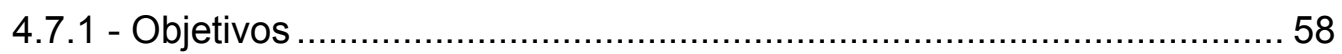

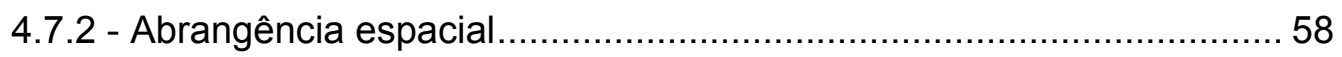

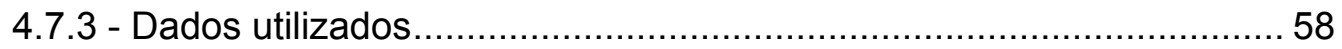

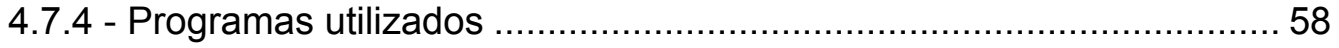

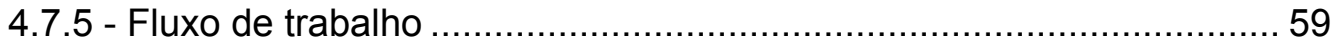

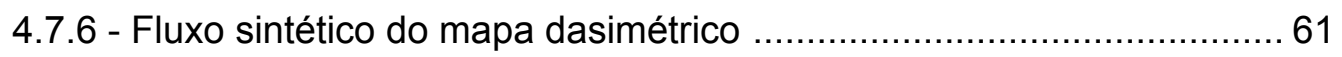

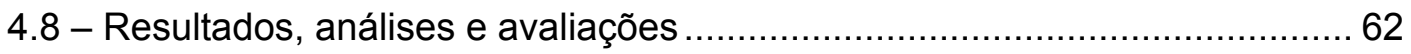

5.0 - TRANSFORMAÇÕES CARTOGRÁFICAS

ESPACIAS DE POSIÇÃO: ANAMORFOSES ….............................................. 77

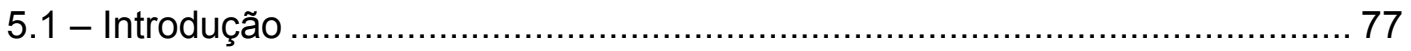

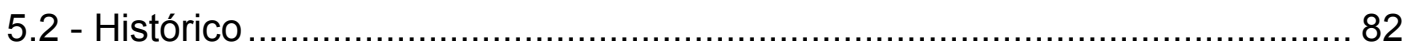

5.3 - Aplicativos, aplicações e avaliações .................................................... 90

6.0 - MODELIZAÇÃO GRÁFICA DA METRÓPOLE DE SÃO PAULO …......................... 103

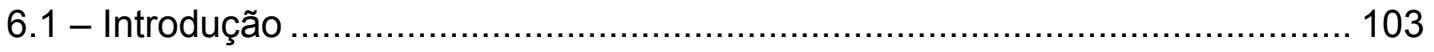

6.2 - A modelização da metrópole............................................................... 112

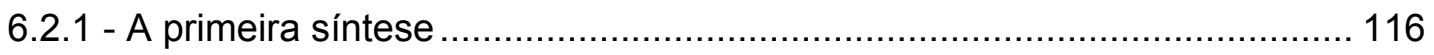

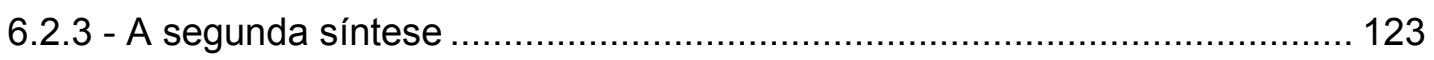

6.3 - Análises e avaliações ....................................................... 128

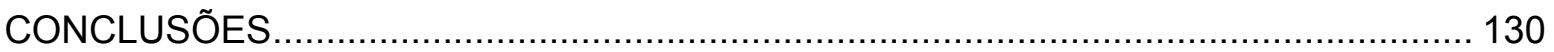

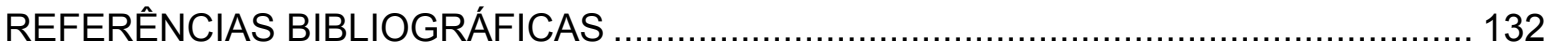

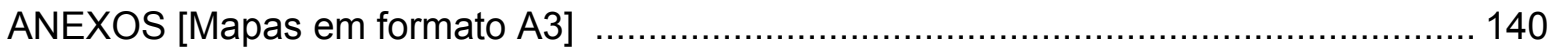




\section{ÍNDICE DE MAPAS}

Mapa 1 - Espaço geográfico produzido na metrópole de São Paulo.............................. 67

Mapa 2 - Espaço urbano da metrópole de São Paulo .................................................. 68

Mapa 3 - Espaço urbano, censitário e "virtual" da metrópole de São Paulo ..................... 69

Mapa 4 - Mapa coroplético da metrópole de São Paulo................................................. 70

Mapa 5 - Mapa dasimétrico da metrópole de São Paulo ......................................................... 71

Mapa 6 - Mapa coroplético da densidade urbana do Município de Osasco....................... 72

Mapa 7 - Mapa dasimétrico da densidade urbana do Município de Osasco ..................... 73

Mapa 8 - Mapa dasimétrico da metrópole de São Paulo

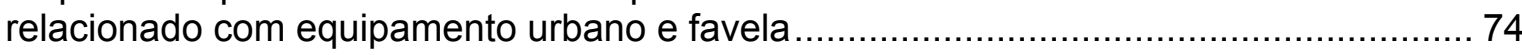

Mapa 9 - Mapa dasimétrico e coroplético da metrópole de São Paulo

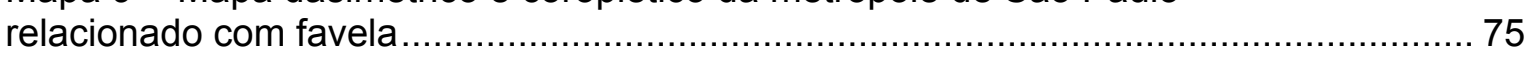

Mapa 10 - Mapa dasimétrico e rede viária e ferroviária .............................................. 76

Mapa 11: Mapa em anamorfose da população residente

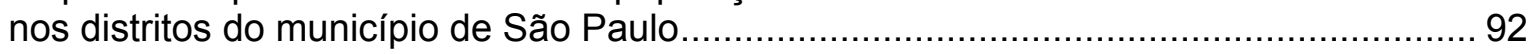

Mapa 12A: Mapa em anamorfose da população residente

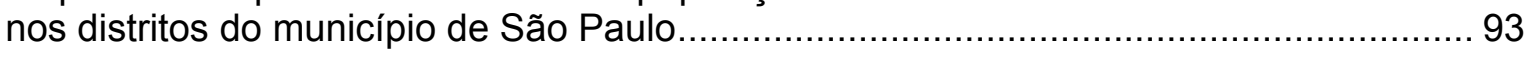

Mapa 12B: Mapa em anamorfose da renda média

nos distritos do município de São Paulo..................................................................... 93

Mapa 13 - mapa em anamorfose da metrópole paulista ............................................... 94

Mapa 14 - Mapa em anamorfose da população dos distritos do município

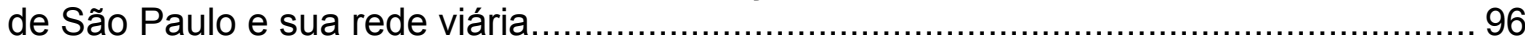

Mapa 15 - Mapa em anamorfose da População Urbana e Rural dos municípios que compõem a região Administrativa de São José dos Campos - Estado de São Paulo......................................................... 97

Mapa 16 - mapa em anamorfose do dasimétrico da metrópole de São Paulo.................. 99

Mapa 17 - mapa em anamorfose do dasimétrico do município de Osasco..................... 100

Mapa 18 - Mapa em anamorfose e Cartograma em anamorfose - PIB e IDHM 2000.

Mapa 19 - Fundo de mapa não euclidiano:

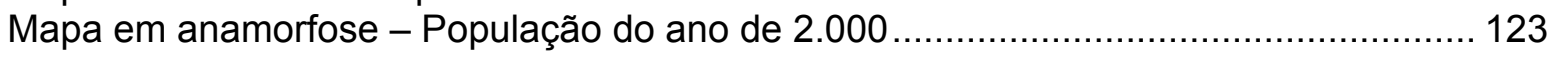




\section{ÍNDICE DE FIGURAS}

Figura 1 - Definições e componentes do mapa ........................................................ 17

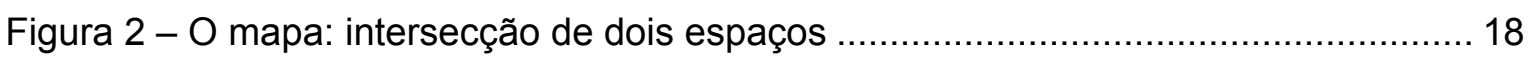

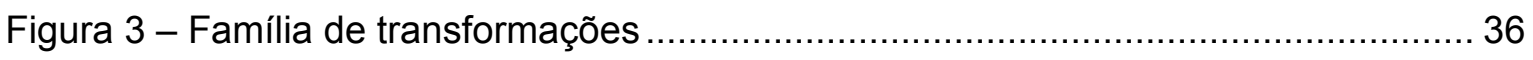

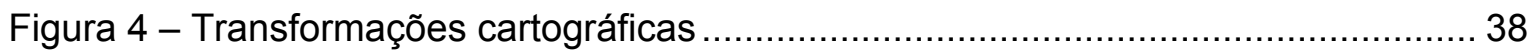

Figura 5 - Tipos de mapas privilegiando uma diferenciação

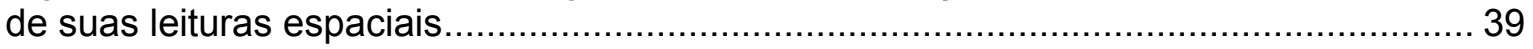

Figura 6 - Mapa de População da Irlanda de HARNESS de 1837 .................................... 46

Figura 7 - Excerto de: “Dazimetricheskaya Karta Evropeiskoi Rossii “ “.......................... 48

Figura 8 - Mapa Coroplético Cape Cod (Estado de Massachusetts) .............................. 49

Figura 9 - Mapa Dasimétrico de Cape Cod (Estado de Massachusetts) ......................... 49

Figura 10 - Exemplo de cálculo de densidade para mapas dasimétricos.......................50

Figura 11 - Fluxo de elaboração de um mapa dasimétrico ........................................... 61

Figura 12 - Anamorfose como transformação cartográfica espacial ............................... 79

Figura 13 - "Accélération des voyages em France depuis 200 ans". ............................ 80

Figura 14 - transformação morfotemática de ligação

A visão do espaço sueco que possui um emigrante na cidade de Asby ......................... 81

Figura 15 - Mapa de fluxo de exportação de carvão (Minard, 1850) ................................ 84

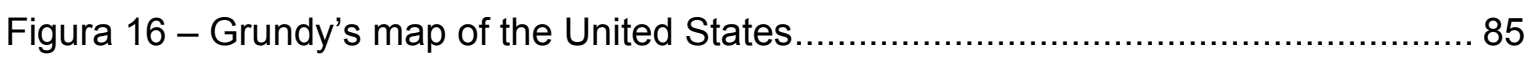

Figura 17 - Cartogramas retangulares estatísticos de Raiz ......................................... 87

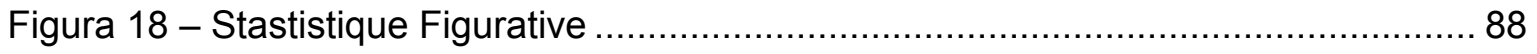

Figura 19 - Primeiros resultados de Tobler com cartogramas

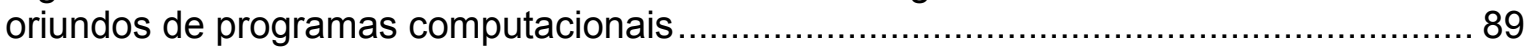

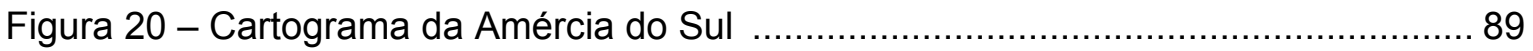

Figura 21- Sequência que o programa Scape Toad usa como princípio de seu processamento na transformação de um fundo de mapa em outro ....................... 95

Figura 22 - Cartogramas em anamorfose .................................................................... 101

Figura 23 - Esquema de ações sociais e estruturas

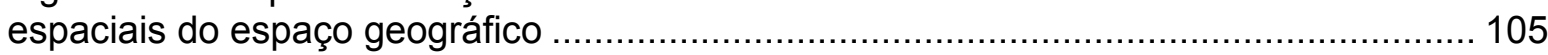

Figura 24 - Modelos elementares e síntese gráfica do território brasileiro ..................... 110

Figura 25 - Modelos elementares e síntese gráfica do território paulista ....................... 111

Figura 26 - Superposição do modelos elementares

a um novo modelo do território paulista

Figura 27 - "Geometrização" do fundo de mapa

euclidiano da metrópole paulista

Figura 28 - Sequência de generalização pelo aplicativo "MapShaper". 
Figura 29 - Modelo elementar 1 - Nosso "Maillage" - O limite metropolitano 116

Figura 30 - Modelo elementar 2 - O centro histórico da metrópole 116

Figura 31 - Modelo elementar 3 - Treillage => a densidade de rede de comunicação $\ldots 117$

Figura 32 - Modelo elementar 4 - Área de serviço de água e drenagem 117

Figura 33 - Modelo elementar 5 - Áreas de indústria 118

Figura 34 - Modelo elementar 6 - Centros de população residente - a densidade populacional.

Figura 35 - Modelo elementar 7 - Densidade de equipamentos urbanos. 119

Figura 36 - Modelo elementar 8 - A extensão urbana 119

Figura 37 - Modelo elementar 9 - A extensão hortifrutigranngeiro 120

Figura 38 - Modelo elementar 10 - A extensão de chácaras para lazer/moradia 120

Figura 39 - Modelo elementar 11 - A extensão da vegetação

Figura 40 - A síntese 1- a modelização gráfica da metrópole 121

Figura 41 - A geometrização da síntese 2 .

Figura 42 - Modelo elementar 12 - Nosso "Maillage" - O limite metropolitano 124

Figura 43 - Modelo elementar 13 - "Gravitation" - [gravitação]

A força de atração do centro da metrópole

Figura 44 - Modelo elementar 14 - "Hiérarquie" - [hierarquia]

Centros secundários da metrópole.

Figura 45 - Modelo elementar 15 - "Hiérarquie" e "Dynamique territoriale" [hierarquia, dinâmica territorial]: área do centro principal e secundário da metrópole => o "file"; área de extensão, expansão

Figura 46 - Modelo elementar 16 - "Treillage" - [ligação]: rede principal de vias de comunicação - as rodovias

Figura 47 - Modelo elementar 17 - "contact" - [contato]: interface urbano

e áreas de proteção ambiental - limites da expansão urbana

Figura 48 - Modelo elementar 18 - "Dynamique territoriale"-

área de "regressão" => área "problema"

Figura 49 - A segunda síntese

\section{ÍNDICE DE QUADROS}

Quadro 1 - Quadro comparativo dos critérios de avaliação para os cinco mapas 63

Quadro 2 - Quadro comparativo dos critérios de avaliação para o mapa e os cartogramas em anamorfose 102

Quadro 3 - Coremas propostos por Brunet 107 


\section{ÍNDICE DE ABREVIAÇÕES}

EMPLASA - Empresa Paulista de Planejamento Metropolitano

ESRI - Environmental Systems Research Institute

ha - Hectare

IBGE - Instituo Brasileiro de Geografia e Estatística

IGC - Instituto Geográfico e Cartográfico

ONU - Organização das Nações Unidas

RMSP - Região Metropolitana de São Paulo

SAD - South American Datum

SEADE - Sistema Estadual de Análise de Dados

SENAC - Serviço Nacional de Aprendizagem Comercial

SIG - Sistemas de Informações Geográficas

TCP - Transformações Cartográficas de Posição

UNESCO - United Nations Educational, Scientific and Cultural Organization VBA - Visual Basic for Applications 


\section{RESUMO}

Esta pesquisa trabalha com dois instrumentos importantes que representam o espaço geográfico, bem como, permitem perceber, conhecer, apreender e atuar sobre a realidade: os mapas e a modelização gráfica. O mapa como uma abstração da realidade espacial, que é modelizado e codificado com o propósito de ser apreendido. Mais que representar fenômenos espaciais, o mapa espacializa os fenômenos que representa, sejam eles espaciais ou não, materiais ou ideais. Todo mapa é fruto de transformações cartográficas espaciais. Transformação no sentido de que vai além da forma original que deveria representar, dando outra forma ao espaço geográfico analisado. Cartográfica, porque o objeto que é transformado é o mapa. Espacial, pois se refere às localizações, direções, distâncias e áreas. A modelização gráfica, por sua vez, é apoiada nos elementos estruturantes primordiais do espaço geográfico: os coremas [chorème]. Sob forma de figuras geométricas simples, os coremas escrituram modelos geográficos e estão estreitamente relacionados e próximos da cartografia, mas não se confundem. A modelização gráfica é geográfica, pois se refere às formas espaciais produzidas na apropriação do espaço pela sociedade. Mapas e modelização gráfica têm a função primordial de comunicar e de serem instrumentos de análise do espaço geográfico. Espaço geográfico compreendido aqui como dimensão da sociedade. Dimensão estabelecida pelo conjunto de relações sociais que se dão simultaneamente e mediadas pela(s) distância(s) que aproximam ou afastam realidade(s) diferentes ou "iguais". Para dimensionar esta sociedade usando o mapa e a modelização gráfica, o recorte espacial foi a metrópole de São Paulo. Metrópole como lugar de concentração humana, de equipamentos culturais, sociais, de densidades e diversidades de um modo de vida típico de nosso mundo atual - o urbano. Espaço representado em mapas e modelos coremáticos por meio de uma característica fundamental que evidencia seu caráter urbano: a densidade. Densidade expressa em mapa dasimétrico - literalmente métrica da densidade - evidenciando particularmente a densidade de população da metrópole e os mapas em anamorfose e cartogramas em anamorfose, que alterando o fundo de mapa tradicional, criam imagens de densidades. Estes mapas revelam estruturas e organizações que ajudam a compor uma síntese gráfica final da metrópole de São Paulo.

Palavras-chave: anamorfose, coremas, espaço geográfico, mapa dasimétrico, modelização gráfica, transformação cartográfica espacial.

e-mail: dutenkefer@gmail.com 


\section{ABSTRACT}

This research discuss two important ways to represent geographical space. Those representation techniques allow us to notice, know, apprehend and face reality: they are maps and graphic modelization. Map as an abstraction of spatial reality modelized and codified to be apprehended. More than represent spatial phenomena, the map turn visible the element that represent. The spatial distribution element might be spatial or not and might be material and ideal or not. Every map results from a spatial cartographic transformation. Transformation considered in a sense that goes beyond the original form that should be represented, giving another form to the analyzed geographical space. Cartographic, since the map is the object to be transformed. Spatial, since it refers to locations, directions, distances and areas. Graphic modelization, is based in the components that express geographic space: the choremes [chorème]. The choremes describe geographical models in graphical forms and are deeply related to cartography, but are not the same. Graphic modelization is geographical, because it refers to the social appropriation of space. Both, maps and graphic modelization aim to analyze and present the geographical space. To analyze the society spatial dimension through graphic modelization, the São Paulo Metropolitan Area was defined. Metropolis characterized by the concentration of people, cultural equipment, densities and diversities of urban life. Space that is represented in maps and with chorematic models that make evident their urban character: density. Density presented in dasymetric maps showing the metropolis population density and the cartogram. Those cartograms presenting the transformed map background generates an image of the densities. Those maps present structure and organization that contribute in the comprehension of the Sao Paulo Metropolis.

Palavras-chave: cartogram, choremes, geographical space, dasymetric map, graphic modelization, spatial cartographic transformation. 


\section{INTRODUÇÃO}

Esta pesquisa teve como origem a possibilidade de realizarmos representações cartográficas não usuais em comparação a uma distribuição espacial tipicamente apresentada pela Geografia por meio de mapas coropléticos. O fio condutor foi então pesquisar as representações temáticas da densidade urbana do município de São Paulo [densidade populacional] utilizando e comparando a técnica coroplética $^{1}$ e dasimétrica ${ }^{2}$ por meio de Sistemas de Informações Geográficas [SIG]. Tínhamos iniciado estas pesquisas em mapas dasimétricos no curso de especialização em Geotecnologias do Centro Universitário SENAC de São Paulo. Aplicamos então, na época, um teste dessa técnica em um recorte espacial que foi a Subprefeitura de Santo Amaro - São Paulo - Capital. Na pesquisa de mestrado ampliamos nosso recorte para a Região Metropolitana de São Paulo [RMSP].

No decorrer das pesquisas alteramos um pouco nosso rumo. Estávamos trabalhando com mapas representativos de densidade - o dasimétrico - do espaço urbano da metrópole. Mas, essa técnica dasimétrica, aprimoraria e permitiria um maior detalhamento na espacialização do fenômeno a ser cartografado que a técnica coroplética? Ela seria representativa do espaço da cidade? Seria interessante fazer outras propostas de representação para que a expressão da densidade pudesse ser mais comunicativa? Densidade de população, concentrações diversas, fundamentais para caracterizar o espaço urbano. Se o mapa é uma representação do espaço geográfico, qual ou quais conceitos a Geografia oferece para refletir? Existiriam outras propostas de representação do espaço geográfico?

Ampliamos assim nosso escopo de pesquisa e incluímos, além do mapa dasimétrico, as anamorfoses e a modelização gráfica como propostas para testar e tentar responder estas indagações.

\footnotetext{
${ }^{1}$ Coroplético: do grego: choros - significa lugar e plethos, quantidade.(MARTINELLI. 1991, p.120)

2 da.si.mé.tri.co: adj (dasi+metro+ico) Pertencente ou relativo à dasimetria. Dasi: elemento composto ( $g r$ dasýs) Exprime a idéia de: 1) Peludo, felpudo: dasianto, 2) Densidade, denso: dasimetria, dasifilo. (Dicionário Babylon - Michaeles eletrônico). Dasimétrico, em inglês dasymetric, literalmente é a métrica da densidade. 3) Fr. Dasymétric "vient de - dasus - em grec, que signifie velu [peludo], touffu [volumoso], épais [espesso], serré[apertado], compact, non clairsemé [não disperso], donc ce qui traduit une densité, une concentration." (CAUVIN, Colette. ESCOBAR, F., SERRADJ, A. Cartographie Thématique 2. Lavoisier, 2007, p.142).
} 
Para responder aos questionamentos teríamos como objetivos principais:

- Produção de mapas de densidade urbana [em particular densidade de população] da metrópole de São Paulo aplicando as técnicas coroplética e dasimétrica;

- Analisar e comparar os resultados das duas técnicas aplicadas à análise da densidade urbana;

- Apresentar e elaborar alternativas de representação do espaço geográfico utilizando transformações cartográficas espaciais que alteram o fundo de referência, o fundo de mapa - a anamorfose;

- Apresentar e elaborar alternativas de representação do espaço geográfico utilizando uma "pós cartografia": a modelização gráfica.

Outra preocupação que amadureceu nesta jornada é que esta pesquisa deveria contribuir para uma prática geográfica mais renovada da Geografia brasileira. Buscamos estas renovações em autores como Milton Santos e Jacques Lévy - o conceito de espaço geográfico; Colette Cauvin e Waldo Tobler Anamorfose, Cartograma; em Roger Brunet e Hérve Théry - a modelização gráfica. Acreditamos que estes autores contribuíram e contribuem para nossas reflexões e temos o dever, como geógrafos, de apresentar alternativas significativas dos modos como representamos o espaço geográfico para nossos alunos, profissionais técnicos e pesquisadores da Ciência Geográfica. Estas reflexões também se enquadram em um saber e um fazer mais ligado a uma Cartografia Geográfica, isto é, a elaborações/reflexões teóricas de uma Geografia mais renovada que orientam práticas cartográficas inovadoras que, em conjunto, contribuem para o fortalecimento da Geografia como ciência.

Os capítulos a seguir indicam a trajetória desta pesquisa com suas reflexões, questionamentos, dúvidas e propostas. 


\section{0 - REPRESENTAÇÃO E MAPA}

Representação é um vocábulo de origem medieval e indica imagem ou idéia de algo. São Tomás de Aquino dizia que representar "significa conter a semelhança da coisa" (ABBAGNANO, 2003, p.853).

Carlo Ginzburg em seu livro, "Olhos de Madeira", nos oferece um ensaio sobre a origem da palavra representação. O termo remonta ao século XIII "représentation" - referindo-se a manequins de cera utilizados junto ao cadáver dos reis franceses e ingleses durante cerimoniais funerários:

Enquanto o soberano era velado, a presença do manequim era um testemunho à transcendência do rei e a sua presença futura no mundo dos mortos. O manequim tinha a função de lembrar aos presentes que o rei havia assumido uma outra forma e que uma nova vida se iniciava para o morto. Nesta nova forma, apesar de morto o rei continuaria presente para seus súditos ("re + présentation"). (GINZBURG, 2001 apud CÂMARA, 2005, p.1)

O significado da palavra "representação" está ligado a uma forma material e imaterial do que conhecemos, percebemos e descrevemos como realidade. A nossa relação com a realidade, por sua vez, está vinculada a um conjunto de manifestações aparentes - os fenômenos - e a um conjunto de instrumentos que permitem o perceber, o conhecer, o apreender e atuar sobre o real. A representação concebida como uma entidade material ou ideal, que estabelece uma forma e um conteúdo de uma entidade postulada do real, responde a esta necessidade. É pertinente o seu uso quando é capaz de constituir um modelo eficiente do real que ele representa (DEBARBIEUX, 2003 e 2009).

As representações espaciais são singulares no sentido de que os objetos e processos que eles expressam, ou seja, a localização, as diferenciações e os limites ou contínuos espaciais, as distâncias e conexões, as interações localizadas e a qualificação de cada tipo de fenômeno são fundamentais para a Geografia. Podem ser do tipo imaterial - uma imagem mental, por exemplo, ou material - um mapa, uma fotografia, etc. (DEBARBIEUX, 2003).

Refletindo com Palsky (2006), um dos instrumentos que permitem perceber, conhecer, apreender e atuar sobre a realidade e que representa o espaço geográfico, é sem dúvida o mapa. O cuidado em utilizar o mapa como representação é salientar que representação pode designar tanto uma figura, uma imagem mental 
que se refira a algo como também expressar o processo pelo qual esta "figura", esta "imagem" foi criada. É bom assinalar o mapa como uma categoria de imagem concreta e como um produto de uma representação. O mapa é uma abstração da realidade espacial que é modelizado e codificado com o propósito de ser apreendido. Mais que representar fenômenos espaciais, o mapa espacializa os fenômenos que representa, sejam eles espaciais ou não, materiais ou ideais!

O processo básico na confecção de um mapa é substituir o espaço real por um espaço analógico. Ele precedeu a escritura e a matemática e só no século XIX foi associado a uma disciplina moderna que se forjou como cartografia (HARLEY, 1991).

Existe uma grande diversidade de formas de representações espaciais em nossa cultura. "Cada sociedade tem ou teve sua própria forma de perceber e de produzir imagens espaciais" (HARLEY, 1991, p.5). Para Harley, o mapa é uma linguagem visual universal e antiga e como um "saber" das diferentes culturas humanas e não como um mero produto técnico. "Os mapas sempre mostram mais que a soma inalterada de um conjunto de técnicas" (HARLEY, 2005, p. 61 tradução nossa). Com esta convicção este autor elabora uma definição ampla do mapa para contemplar as diversas culturas humanas em diferentes épocas:

Representação gráfica que facilita a compreensão espacial de objetos, conceitos, condições, processos e fatos do mundo humano. (HARLEY, 1991, p.5)

...são textos no mesmo sentido que o são outros sistemas de signos não verbais como os quadros, o teatro, o cinema, a música, a televisão... são uma linguagem gráfica que se deve codificar. São uma construção da realidade, imagens carregadas de intenções e conseqüências que se podem estudar nas sociedades de seu tempo. (HARLEY, 2005, p. 62 - tradução nossa)

Na mesma linha de Harley - o mapa como linguagem - Lévy (2003b e 2008) situa o mapa como meio termo entre uma linguagem simbólica - pintura abstrata, uma expressão matemática, por exemplo - e o "figurativo" - a fotografia, o cinema; por outro lado é oposto às linguagens seqüenciais. O mapa é simultaneamente analógico e simbólico, não verbal e não seqüencial. Sendo uma linguagem não sequencial, o mapa está alinhado às figuras - que são opostas aos discursos - e pertencem ao mundo das imagens com uma leitura global e instantânea. Ele tem a possibilidade de apresentar simultaneamente ao "leitor"/visualizador o conjunto da informação representada. 
Baseado em uma linguagem construída a partir de uma imagem analógica do espaço, esta representação - o mapa - deveria comportar:

1. Instrumentos para identificação do espaço-referente;

2. uma ou várias escalas cartográficas;

3. um princípio de transposição analógico de localizações de algum espaço para o mapa;

4. uma ou várias métricas;

5. um ou vários "temas", quer dizer: uma substância ${ }^{3}$

6. uma semiologia de representação gráfica ("legenda") dos objetos que correspondem a esses temas e das relações entre esses objetos. (LÉVY, 2003b, p.128)

Na obra coletiva de Cauvin, Escobar e Serradj - Cartographie Thématique os autores tentam sintetizar as várias conceituações que o mapa recebeu e recebe como um dos principais representantes instrumentais e analíticos do labor geográfico:

Um mapa é uma representação geométrica, convencional de uma parte da superfície terrestre ou qualquer outro planeta, ou seja, uma representação em posições relativas, de fenômenos concretos ou abstratos, localizáveis no espaço, caracterizado por atributos espaciais e não espaciais; é um modelo conceitual de um espaço dado, implicando uma redução (expresso por uma escala), uma simplificação, uma generalização deste espaço. É igualmente um modelo icônico, recorrendo a sinais, códigos numéricos, visuais, sonoros, táteis. Esta representação se efetua sobre um apoio, frequentemente plano, permanente (sobre papel por exemplo), temporário ou mesmo virtual (ecrã), sob uma forma ou outra (planos, modelos tridimensionais, globos...), concebido em um momento dado do tempo, num contexto histórico, societal. É estabelecido por um (ou dois) objetivo(s) preciso(s), a fim de apresentar ou transmitir informações em função do utilizador, exprimindo (explicitamente ou não), revelando as relações espaciais entre os elementos, as variações dos fenômenos no tempo bem como os seus movimentos, os seus deslocamentos. Necessita de escolhas que implicam necessariamente a integração consciente ou não da subjetividade do seu autor, o mapa é, em seu processo assim como no seu resultado, a projeção, a materialização de um esquema mental sobre um apoio qualquer que seja. (CAUVIN et all, 2007, p.58, tradução nossa)

Elaboramos um pequeno quadro - figura 1 - com as principais reflexões de Harley, Palsky, Lévy e Cauvin, sintetizando sobre o que o mapa é.

\footnotetext{
${ }^{3}$ Segundo Lévy - componente não espacial de uma configuração espacial.
} 


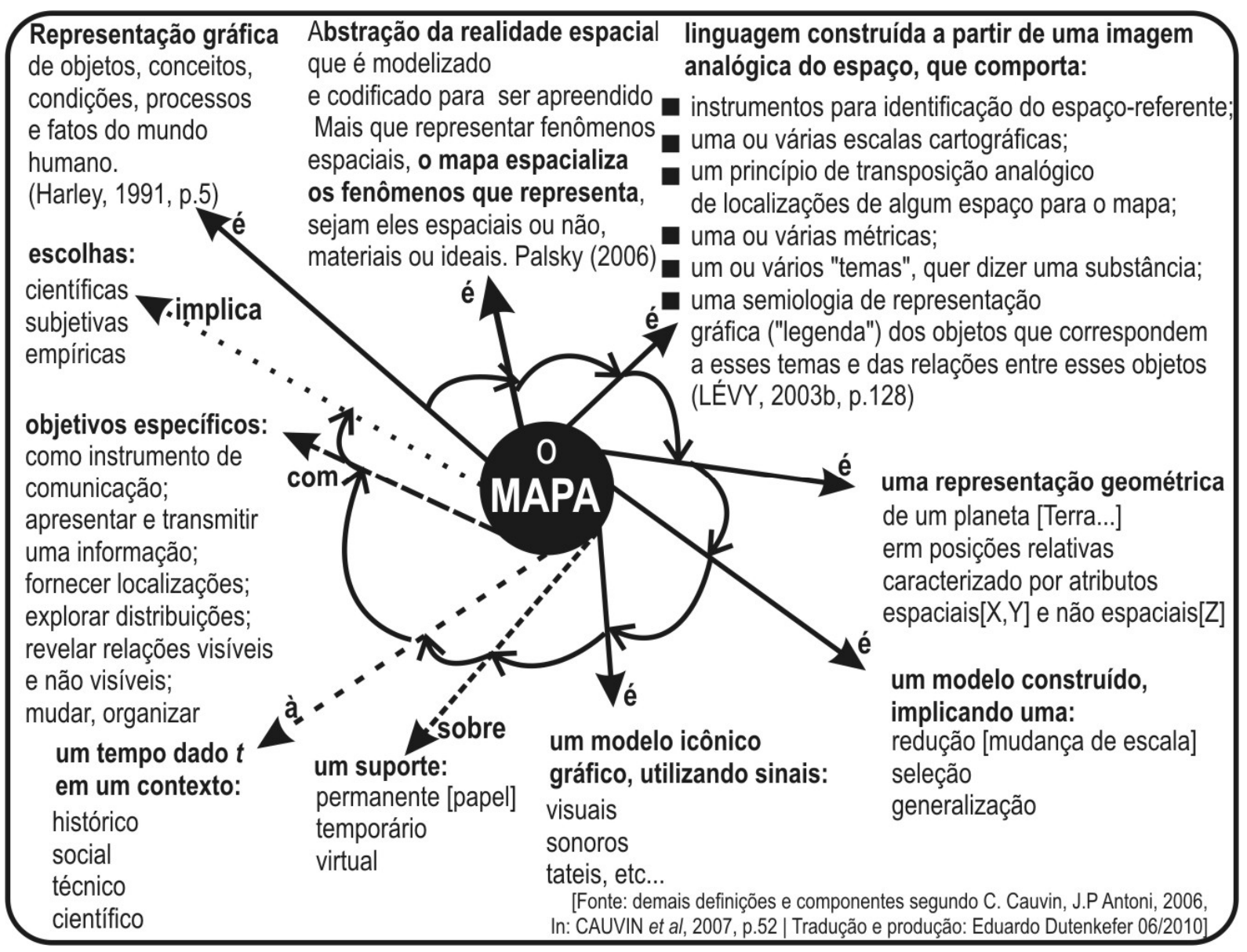

Figura 1: Definições e componentes do mapa

O mapa tenta reproduzir o espaço geográfico "graças ao princípio de analogia, e visa a (re)apresentar" ("re + présentation") "os objetos segundo as mesmas disposições, relações e dimensões pelas quais elas são percebidas na realidade" (CASTI, 2003, p.134).

Cauvin et al, (2007, p. 69) nos apresenta uma imagem [a partir de Sylvie Rimbert ${ }^{4}$ ] onde o mapa é a intersecção de dois espaços - figura 2 - do espaço matemático/geométrico que contém os localizantes espaciais [XY] - o suporte, o fundo de referência, o fundo de mapa e o espaço temático, que contém os "atributos", a(s) variável(is) temática(s), o fenômeno que queremos representar, a substância segundo Lévy. Nesta intersecção teremos o espaço cartográfico. Para Lévy (2003b e 2008) este espaço - o mapa - possui dupla espacialidade - o de referência e o da linguagem. Uma analogia com o esquema de Rimbert \& Cauvin seria que o espaço de referência é o espaço dos localizantes espaciais; o espaço da linguagem seria o espaço "temático", aquele onde os fenômenos são espacializados

\footnotetext{
${ }^{4}$ RIMBERT, S. et al., Cartographie informatisée et géographique humaine. ATP 3457 CNRS-LCT, tome 2, fascicule A: Expérimentations em cartographie transformationnelle, 76 . + annexes, 1979.
} 
segundo uma "gramática" que toda linguagem possui. O mapa não é o espaço geográfico, mas ele é um espaço que permite uma leitura espacial, instantânea e global do fenômeno que representa. Ele é um - entre outros - instrumento para a Geografia apreender a dimensão espacial das sociedades, ele "se apresenta como uma manifestação concreta do objeto da geografia" (LÉVY, 2004, p.4 - tradução nossa).

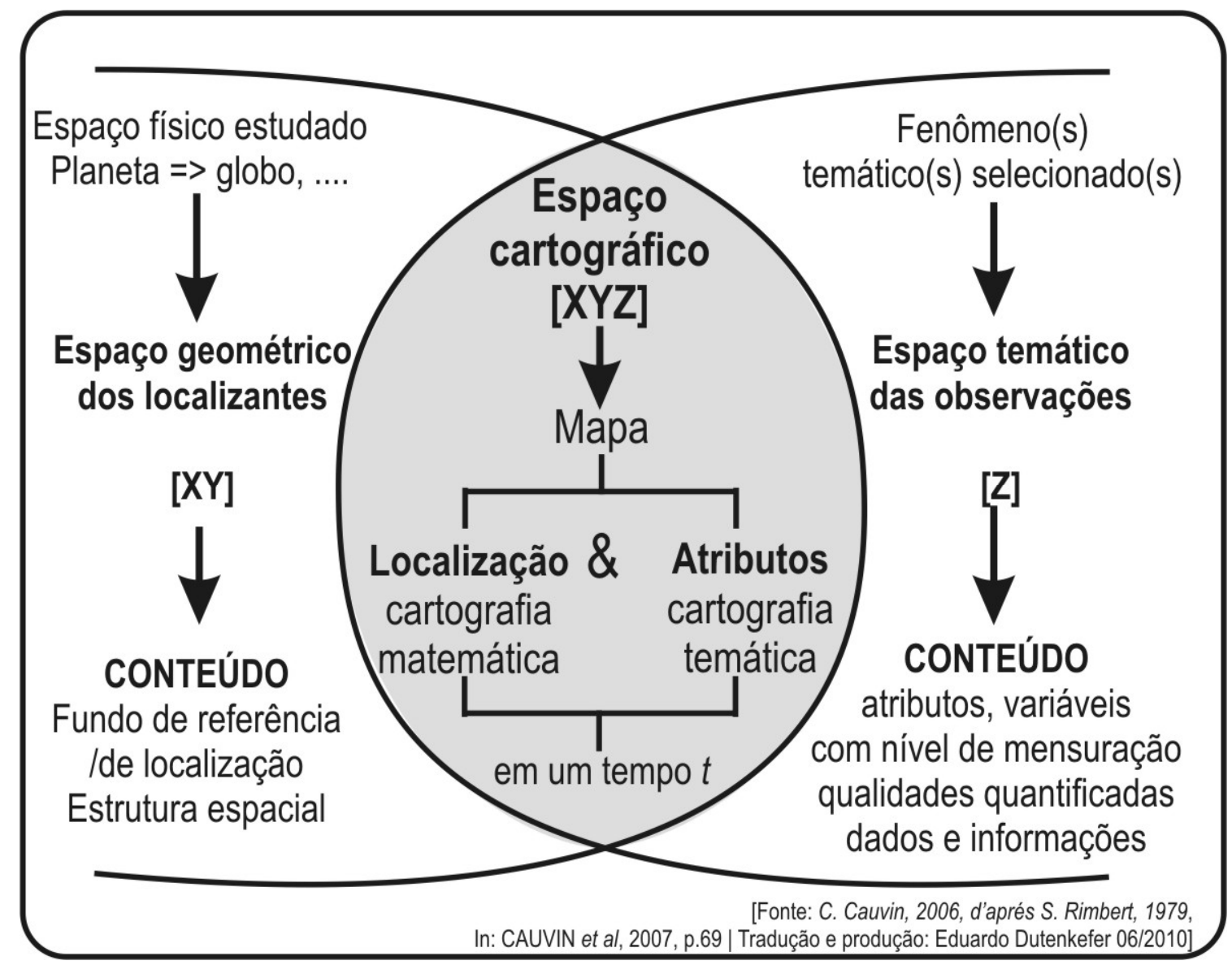

Figura 2 - 0 mapa: intersecção de dois espaços

O mapa, apresentando-se assim como candidato a representar o espaço geográfico, foi tradicionalmente classificado, separado em dois mundos. $O$ mundo da cartografia sistemática - a cartografia matemática - e o mundo da cartografia temática. Para Archela (2.000, p.1), a cartografia sistemática tem como preocupação central a localização precisa dos fatos na implantação e manutenção das redes de apoio geodésico, na execução dos recobrimentos aerofotogramétricos e na elaboração e atualização dos mapeamentos básicos, enquanto que a temática tem como preocupação básica a elaboração e o uso dos mapeamentos temáticos, abrangendo a coleta, a análise, a interpretação e a representação das informações 
sobre uma carta base [um fundo de carta - fundo este representativo de uma realidade que foi construída com instrumentos matemáticos]. A temática Importar-seia mais com o conteúdo que vai ser representado no mapa do que com a "precisão" dos contornos ou da rede de paralelos e meridianos. Não temos motivos para duvidar que os "dois mundos" tradicionalmente classificados como cartografia sistemática e cartografia temática podem ser sintetizados em apenas uma única expressão fundamental para a Cartografia-Geográfica: todo mapa é temático. Mesmo a tradicional carta topográfica - representante principal da cartografia matemática - o que nos revela? Revela os elementos planimétricos e altimétricos fundamentais para apreensão do espaço físico, focado em localizações, toponímias, contigüidades, modelado do relevo, com métricas obviamente euclidianas para mensurar tais temas.

Nestas tentativas de representações da realidade dos mais diferentes fenômenos naturais e humanos, em particular para a nossa reflexão, o espaço geográfico - o computador atualmente tem um papel de peso. Com o "advento da revolução quantitativa" - introdução de métodos quantitativos para as ciências humanas - Geografia, História, Ciências Sociais - ganha destaque nos fins de 1950 e início de 1960. As primeiras representações computacionais não eram visualizadas espacialmente. A partir da década de 1970 - sistemas de informações geográficas são desenvolvidos e no final da década de oitenta, com o desenvolvimento e implementação de interfaces gráficas no universo dos computadores, bem como o surgimento dos PCs (personal cumputers), permitem que as representações espaciais sejam incorporadas e visualizadas cartograficamente (ALMEIDA, 2007, p.19).

Estes novos instrumentos são aglutinados no que denominamos de Geoprocessamento ou Geotecnologias, isto é, tecnologias que "abrangem o conjunto de procedimentos de entrada, manipulação, armazenamento e análise de dados espacialmente referenciados". Seus pilares são: o Sensoriamento Remoto, Cartografia Digital, os Sistemas de Informações Geográficas e os Sistemas Globais de Navegação por Satélite. Sistemas de Cartografia Digital originalmente conhecidos como CAD (Computer Aided Design) transformam a cartografia analógica em digital e impulsionam os Sistemas de Informações Geográficas (SIG). Estes são sistemas baseados em computador que permitem ao pesquisador/usuário coletar, manusear e 
analisar dados georeferenciados (georeferenciados - isto é, entidades geográficas referenciadas espacialmente ao terreno por meio de sua localização, utilizando um sistema de coordenadas conhecido). "Estes sistemas são combinações de hardware, software, dados, metodologias e recursos humanos que produzem e analisam informações geográficas" (CHRISTOFOLETTI\&TEIXEIRA, 1997, p.119 e 121) e que podem ou não ter como produto final um ou vários mapas.

É importante salientar que autores fora da ciência geográfica buscam conceitos e diálogo com a Geografia. Criam conceitos e representações como, por exemplo, Monteiro, Câmara e Ramos em "Territórios Digitais Urbanos" que desenvolvem o que denominam de "territórios digitais" como sendo

as diferentes representações da realidade geográfica em um ambiente computacional. A noção de territórios digitais pretende ser mais abrangente que o simples conceito de criação de mapas por meio de sistemas de informação. A idéia-chave é o conceito de representação computacional, que implica o uso de modelos lógicos, estruturas de dados, algoritmos e linguagens para capturar as diferentes dimensões do espaço geográfico. (MONTEIRO, CÂMARA, ALMEIDA, 2007, p. 35)

Com este conceito - Territórios Digitais - estes pesquisadores brasileiros lançam um projeto de diálogo ou lançam uma questão, uma provocação, um desafio aos geógrafos? "Território digital" é um conceito de representação da realidade geográfica mais abrangente que o "simples" elaborar/criar mapas por meio analógico e/ou digital? "Capturar as diferentes dimensões do espaço geográfico" - é este o desafio para a Geografia e ciências afins, preocupados com a dimensão espacial da sociedade humana.

Mas qual o conceito - ou conceitos - de espaço geográfico que iremos trabalhar? 


\section{0 - CONCEITOS DE ESPAÇO GEOGRÁFICO}

Segundo Moraes, (2000, p.18) o que conhecemos como geografia remonta à antiguidade clássica e diferentes povos forjaram "conjuntos de conhecimentos e indagações, geralmente referidos à superfície da Terra e à descrição dos lugares terrestres". Ainda segundo Moraes o temário geográfico atual é herdeiro destas tradições e '"objetiva-se pela aplicação de orientações metodológicas que selecionam, articulam e definem procedimentos para a análise dos fenômenos e processos ali indicados." Assim cada método organiza o temário e organiza teoricamente o objeto da Geografia.

Os fundamentos das ciências são baseados, ou pelo menos deveriam ser, em como conceituar os vários fenômenos de estudo de forma a criar uma unanimidade em uma comunidade científica, ou seja, um paradigma. São criados modelos que tentam explicar o maior número possível de experimentos ou investigações científicas. Mesmo que não sejam unanimes, sempre ocorrem dissidências, são dominantes em certo período histórico.

As várias formas de abordar o espaço geográfico criaram diversos paradigmas na história do pensamento geográfico desde que a geografia se tornou ciência no final do século XIX. Como abordar este espaço na Geografia deu origem à Geografia Regional com seus conceitos de região natural, baseado no paradigma do determinismo ambiental, e de região geográfica como segundo paradigma, baseado no possibilismo.

\section{$2.1-1^{0}$. paradigma: determinismo ambiental}

Uma das primeiras formulações, a da região natural, se deve à corrente geográfica denominada de "determinismo ambiental" (ou seria melhor chamá-la de "determinismo natural"?). Sua origem remete-se a Lamarck e Darwin e na Geografia seu expoente foi Frederic Ratzel e seus discípulos. Para esta corrente, as condições naturais (o meio físico) determinam o comportamento, a evolução e o desenvolvimento dos homens. Portanto, o estudo das relações homem-meio, com base no método positivista, vai afirmar que as condições naturais é que determinam o comportamento humano. Assim, o conceito de região natural

é entendido segundo escalas territoriais diversificadas, e caracterizado pela uniformidade resultante da combinação ou integração em áreas dos elementos da natureza: o clima, a 
vegetação, o relevo, a geologia e outros adicionais que diferenciariam ainda mais cada uma dessas partes. Em outras palavras, uma região natural é um ecossistema onde seus elementos acham-se integrados e são interagentes". (CORRÊA, 2002, p. 23 e 24).

É interessante notar que nesta concepção de região natural os elementos da natureza são na verdade os meios físico e biológico característicos da região em questão.

Uma região natural é uma parte da superfície da terra no interior da qual os diferentes elementos físicos e biológicos, em ação recíproca e inseparáveis, constituem uma unidade. (MONBEIG, 1957, p. 127)

O homem está fora deste quadro, como se o homem não fizesse parte integrante da natureza. Além disso, dizer que região natural é um "ecossistema onde seus elementos acham-se integrados e são interagentes "é redundante, pois, a noção de ecossistema já contempla esta interação e integração, passando a idéia de "harmonia"”e "equilíbrio" desta região.

\section{2 - $2^{0}$ paradigma: possibilismo}

Contrapondo-se a corrente determinista, um segundo paradigma - a corrente Possibilista ou Lablachiana (Vidal de La Blache), também no século XIX - na França e com o mesmo método positivista, afirma o não determinismo das condições naturais sobre o homem. Inclui a ação do homem como um fator a ser considerado no estudo da relação homem-meio. A natureza forneceria possibilidades para que o homem a modificasse. $O$ homem de posse de técnicas, hábitos, usos e costumes (os gêneros de vida segundo La Blache) utilizaria os recursos que a natureza oferece. Nesta concepção o conceito de região vai configurar como uma região humana e a região estudada será a região geográfica. Esta região na concepção Lablachiana

abrange uma paisagem e sua extensão territorial, onde se entrelaçam de modo harmonioso, os componentes humanos $\mathrm{e}$ natureza.(CORRÊA, 2002, p. 28)

Nesta concepção região e paisagem se confundem. A Geografia Regional Possibilista se torna um estudo da paisagem. O geógrafo deverá delimitar, descrever e explicar esta região, deixando claros seus limites e seus elementos constituintes.

Para Pierre Monbeig:

A região geográfica é uma unidade regional onde se processou a síntese entre as condições físicas e os fenômenos humanos. Num quadro natural bem determinado, desenvolve-se um complexo de 
atividades humanas que apresenta uma certa harmonia com as condições do meio físico-biológico. Somente após uma necessária e longa experiência do meio se chegou a esta espécie de equilíbrio perfeito. (MONBEIG, 1957, p. 142)

"Entrelaçam de modo harmonioso os componentes humanos e natureza" e "desenvolve-se um complexo de atividades humanas que apresenta uma certa harmonia com as condições do meio físico-biológico"... lembra o ecossistema da região natural.

\section{$2.3-3^{0 .}$ paradigma: método regional}

Um terceiro paradigma é o método regional, desenvolvido por Hartshorne (1899-1992) que elaborou seu modelo (o conceito de diferenciação espacial ou de áreas) baseado em estudos do geógrafo alemão Alfred Hettner (1859-1914). Nas palavras de Hartshorne o seu modelo

decorre da síntese, efetuada por Richthofen, dos pontos de vista de
Humbold e Ritter, e foi exposto da maneira mais completa nos
escritos de Hettner... em 1898, ele verificou que "a matéria
específica da Geografia, desde os tempos mais remotos... consiste
no conhecimento das áreas da terra na medida em que diferem umas
das outras; o homem está incluído como parte integante da natureza
de uma áreas e que, dado o avanço geral da ciência, "a mera
descrição foi substituída, em todos os ramos da Geografia, pela
busca das causas". (HARTSHORNE,1978, p.13)

Hettner faz da geografia regional ou especial uma ciência idiográfica (idio, do grego idios, próprio), onde as regiões seriam únicas e integrariam diversos elementos neste mesmo espaço. Para Hettner a Geografia tem um caráter corológico (coro - do grego Khoros, país, região) isto é, um caráter de conhecer países ou regiões compreendendo os seus diferentes fenômenos, coexistindo em uma mesma região. Assim, a Geografia estudaria a diferenciação de áreas, onde procuraria explicar o por quê e em que as regiões da superfície da terra se diferenciam. Hettner queria combater o dualismo entre geografia física e humana. Ela seria ao mesmo tempo uma ciência física e humana. A Geografia Geral, enquanto estudo da descrição da terra, não teria sentido, pois a terra, enquanto sujeito, não é homogênea. A Geografia seria corológica onde deveria descrever, definir e comparar as suas unidades particulares - as regiões - integrando seus variados fenômenos heterogêneos.

Harthshorne vai centrar e valorizar seus estudos na Geografia Regional onde a região não é o objeto da Geografia. Ela é um método capaz de identificar 
diferentes áreas, onde é analisada não como relações do homem-natureza e sim como resultante dos diferentes fenômenos heterogêneos integrados (caráter corológico).

A Região, para Harthshorne, é uma área, um espaço que mostra a sua unidade resultante da integração única de vários fenômenos heterogêneos. Esta área não existe como realidade concreta, ela é abstrata, construída racionalmente, mentalmente pelo pesquisador.

A área é construída idealmente pelo pesquisador, a partir da
observação dos dados escolhidos. Desta forma, a área seria um
instrumento de análise, ao contrário da região ou território, que eram
vistos como realidades objetivas exteriores ao observador. A área
seria construída no processo de investigação. (MORAES, 2002, p.
88).

Assim Harthshorne cria um método, o regional, onde estuda a integração de diferentes fenômenos heterogêneos em áreas, em espaços específicos. Este estudo contribui assim para analisar as diferenciações de áreas. Integrando estes estudos teremos a Geografia como uma Ciência de síntese.

Estudando um só lugar, uma área especifica e tentando apreender os múltiplos fenômenos presentes nesta área teríamos uma Geografia Idiográfica e, como produto deste estudo, um conhecimento profundo deste lugar.

Com seu método da Geografia Regional, Harthshorne representa uma tentativa de dar sobre-vida à Geografia Tradicional e dá sinais claros com seu método abstrato e quase matemático - com os conceitos de "áreas" e "integração" de contribuir para um novo paradigma - o da Geografia Pragmática.

No século $\mathrm{XX}$ o positivismo ganharia ares matemáticos, lógicos - 0 positivismo-lógico. A observação, o empirismo, característico do positivismo tradicional, perderá a sua força e em seu lugar a matemática será eleita como único método capaz de formular leis, gerar modelos e a prever os comportamentos futuros dos fenômenos estudados. Defenderá uma única linguagem - a matemática - para todas as ciências. A Geografia irá sofrer uma "revolução quantitativa". Incorporam-se métodos estatísticos, geométricos, probabilísticos e de sistemas ao seu objeto de estudo. 


\section{4 - Um quarto paradigma? A Região como classe de áreas}

De posse desta "nova" linguagem - a matemática - a Geografia transforma a Região em um conceito abstrato. Para satisfazer aos critérios impostos pelo positivismo lógico e tornar-se um conceito científico, a região terá que ter "uma formulação clara de seu sentido, de seus critérios e de sua natureza. Estabelecer uma região passa a ser uma técnica da Geografia, um meio para demonstração de uma hipótese e não mais um produto final do trabalho de pesquisa" (GOMES, 1995. p. 63). A região, assim, deixa de ser concreta e será definida por procedimentos classificatórios. Será uma classe de área, definida matematicamente como sendo

Um conjunto de lugares onde as diferenças internas entre esses lugares são menores que as existentes entre eles e qualquer elemento de outro conjunto de lugares. (CORRÊA, 2002, p.32)

O que é igual ou diferente entre lugares é medido via técnicas estatísticas. Se estas técnicas forem eficientes poderemos definir as regiões e estudar uma divisão regional com precisão. Teremos assim, os mesmos resultados, independentemente de serem realizados por diferentes pesquisadores. Não necessitamos de nenhuma base empírica (a observação) prévia para o seu estudo. O pesquisador, segundo o seu propósito, irá estabelecer quais critérios serão selecionados para o estudo de uma divisão regional. Por exemplo, para definirmos uma região climática utilizaremos informações, dados exclusivos do clima daquele lugar.

Apesar de depender do propósito do pesquisador - poderíamos ter " $n$ " propósitos diferentes para definir uma região - o que se verificou na perspectiva da "Nova Geografia" é que a análise regional ficou pautada - segundo CORRÊA (2002) - a dois enfoques: as regiões simples ou complexas e as regiões homogêneas ou funcionais.

A região simples seria definida como sendo aquela caracterizada por apenas um dado, uma única variável ou critério de análise. Por exemplo, o da população, o dos tipos de solos, etc.

A região complexa seria definida por vários critérios, variáveis, que geralmente seriam reduzidos a poucas, via técnicas estatísticas. Por exemplo, ao definirmos uma região econômica de um país utilizaremos vários critérios para sua composição - renda da população, a produção industrial, a agrícola, etc. 
A região homogênea seria definida como uma unidade agregada de áreas. Esta unidade teria suas características medidas estatisticamente e se seus valores não se alterariam substancialmente em relação ao espaço e tempo, definindo assim espaços relativamente homogêneos. Fazendo uma analogia com a Física, estas unidades poderiam ser o que conceitualmente denominamos de espaço absoluto. (o espaço e o tempo não variam). Resumindo: unidades que apresentem características estatísticas semelhantes são regiões homogêneas. Por exemplo, a densidade demográfica, a porcentagem de população urbana e rural, a produção agropecuária, etc.

As regiões funcionais são unidades onde suas características mensuradas estatisticamente variam em relação ao espaço e ao tempo. De novo, fazendo uma analogia conceitual em Física, teríamos a noção de espaço relativo onde localizar um ponto depende da posição em relação a outros e que pode variar com o tempo e com a abordagem utilizada. Elas indicam movimento, fluxo dos fenômenos considerados - por exemplo, movimento de pessoas, mercadorias, informações, etc. Estes movimentos, estes fluxos influenciam espaços vizinhos configurando o que ficou conhecido como "regiões polarizadas". Por exemplo, as cidades organizariam sua hinterlândia - ou seja, seu espaço de influência - e que por sua vez organizariam outros centros urbanos menores. "Esta concepção leva Pierre George a afirmar ironicamente que antes, ou seja, na geografia clássica, a região fazia a cidade e agora, na geografia moderna, a cidade faz a região."(GOMES,1995. p 64)

\section{5 - "Medir para refletir ou refletir para medir?"5 *}

A Geografia Tradicional é criticada pela "Nova Geografia" por não ter formulado teorias consistentes que tornassem a Geografia uma verdadeira Ciência. Para formular, então, um novo paradigma, a "Nova Geografia" vai se candidatar a ser a possuidora de um método (o positivismo lógico ou "método científico") capaz de "estimular o desenvolvimento de teorias relacionadas com as características da distribuição e arranjo espaciais dos fenômenos." (CRISTOFOLETTI). Nesta direção teremos o desenvolvimento de várias teorias de localização, como a Teoria dos Lugares Centrais, de Christaller (1933), a de localização industrial, de Weber (1909), entre outros.

${ }^{5}$ SANTOS, 2002a, p.69 
Apesar de vários estudos sobre distribuições espaciais a "Nova Geografia" não conseguiu de fato estabelecer teorias significativas que levassem a estabelecer um novo paradigma. Na verdade ela desenvolve novos ferramentais - com o uso da matemática - para estabelecer diretrizes para que na mão dos órgãos de planejamento do estado, ou privado, mantivessem a realidade existente. Orientou "a alocação de capital no espaço, propondo reformas, atenuando contradições ambientais e gerando informações para a expansão das relações capitalistas de produção" (MORAES, 2002. p 108)

Criticar o caráter "quantitativo", matemático da "Nova Geografia" não significa que devemos extirpar da Geografia tais métodos. Na verdade devemos encará-los como instrumentos de trabalho de qualquer pesquisador.

A quantificação representa apenas um instrumento ou, no máximo, o instrumento. Seria melhor chamar a atenção sobre os aspectos mais teóricos ou conceituais, quer dizer, sobre os próprios paradigmas. $\mathrm{O}$ que continua fundamental é a construção teórica. (SANTOS, 2002a, p.73)

Quando o geógrafo determina quais variáveis serão analisadas no estudo regional devemos questionar os critérios que o levaram a selecionar esta ou aquela variável. Definir estes critérios reservará o sucesso ou fracasso de sua análise.

É dá maior ou menor capacidade de separar as variáveis de uma dada situação que depende o sucesso da análise qualitativa e das tentativas de uma análise quantitativa. A análise das realidades geográficas não pode ser válida sem a possessão de um armamento teórico susceptível de reconhecer em cada variável seu valor respectivo. (SANTOS, 2002a, p.73)

\section{6 - Um quinto paradigma? Organização Espacial}

Em todo seu desenvolvimento histórico a Geografia sempre debateu o seu objeto de estudo. Seria a paisagem, a região, o espaço? Para Corrêa (2002), a Geografia é uma Ciência Social e como tal seu objeto de estudo é a sociedade.

O objetivar a sociedade é viabilizado pelo estudo da sua organização espacial. É este o modo particular da Geografia de estudar a sociedade.

A objetivação do estudo da sociedade pela Geografia faz-se através de sua organização espacial, enquanto as outras ciências sociais concretas estudam-na através de outras objetivações. (CORRÊA, 2002, p.52) 
Esta organização espacial, segundo CORRÊA, também expressa um fenômeno da sociedade e, portanto é também um objeto de estudo, pois materializa o social.

Partindo da necessidade de sobrevivência da humanidade o homem transforma, por meio de seu trabalho, a natureza. Assim a natureza primitiva, a primeira natureza, é transformada em segunda natureza. Esta segunda natureza é a organização espacial transformada pelo trabalho social realizado pela sociedade. Para Corrêa a organização espacial tem vários sinônimos: estrutura territorial, configuração espacial, espaço geográfico, espaço social, etc.

A sociedade produz o seu espaço social, ela organiza este espaço, ela transforma este espaço segundo suas necessidades e ao mesmo tempo esta organização espacial condiciona a sua reprodução, a sua manutenção futura.

A organização espacial, ou seja, o conjunto de objetos criados pelo homem e dispostos sobre a superfície da Terra, é assim um meio de vida no presente (produção), mas também uma condição para o futuro (reprodução). (CORRÊA, 2002, 55)

A organização espacial será reflexo de determinado grupo social que a criou. Assim, refletirá o seu caráter de classe - como produtor e como consumidor - além de estabelecer as relações de controle e de domínio entre as classes sociais envolvidas nesta construção e organização espacial. A organização espacial sobre o capitalismo vai ser um espelho do desenvolvimento das forças produtivas e das relações de produção que estabelecem as relações entre as classes sociais assim constituídas e seus conflitos.

Sobre o capitalismo, a organização espacial fixa espaços para os meios de produção, de circulação, de consumo, de controle e de decisões. Para operacionalizar estes espaços o capital necessita de fluxos de força de trabalho e de matérias primas, fluxos de bens para os espaços de consumo e realimenta estes fluxos para os espaços de decisão e controle.

Ao criar tais espaços o capitalismo organiza o espaço constituindo "inúmeras cristalizações" e, segundo Corrêa:

a sociedade concreta cria seu espaço geográfico para nele se realizar e reproduzir, para ela própria se repetir. Para isto, cria formas duradouras que se cristalizam, sobre a superfície da Terra (CORRÊA, 2002, 57). 
Estas organizações espaciais específicas criam uma organização espacial global, a organização do espaço capitalista. Esta organização global é o resultado da "superposição de diferentes organizações espaciais específicas".

Para controlar e regular esta organização espacial global o Estado se faz necessário, via planejamento territorial ou via alianças com grandes corporações capitalistas para normalizarem e regularem os múltiplos interesses do capital, possibilitando que as diversas organizações espaciais específicas utilizem as diversas formas espaciais já cristalizadas.

Para analisar a organização espacial e sua evolução, Corrêa utiliza 4 categorias analíticas desenvolvidas por Milton Santos; a forma, a função, a estrutura e processo que permitem "a compreensão da totalidade social em sua espacialização".

Forma, função, estrutura e processo são quatro termos disjuntivos, mas associados, a empregar segundo um contexto do mundo de todo dia. Tomados individualmente apresentam apenas realidades, limitadas do mundo. Considerados em conjunto, porém, e relacionados entre $\mathrm{si}$, eles constroem uma base teórica e metodológica a partir da qual podemos discutir os fenômenos espaciais em totalidade (SANTOS, 2008, p.71).

Segundo Corrêa (2002) e Santos (2008) a forma "é o aspecto visível, exterior, de um objeto", além dos diversos arranjos que pode tomar, constituindo assim um padrão espacial. São exemplos de formas; as casas, as cidades, etc.

Ao criarmos um objeto, uma forma, a atividade ou a tarefa que desempenhará, constituirá a sua função. São exemplos de funções; o habitar, o viver, o trabalho, etc. Criada uma forma ela desempenhará uma ou várias determinadas funções - que na configuração da organização espacial serão indissociáveis.

Tendo um objeto, uma forma - o seu modo de organização, a relação entre estes - determinarão uma estrutura.

Estrutura é a natureza social e econômica de uma sociedade em um dado momento do tempo (CORRÊA, 2002, 77).

Por último o processo

é definido como uma ação que se realiza continuamente, visando um resultado qualquer, implicando tempo e mudança. Os processos acontecem dentro de uma da estrutura social e econômica e 
resultam das contradições internas da mesma... Processo é uma estrutura em seu movimento de transformação (CORRÊA, 2002, 77).

Para analisarmos uma organização espacial estas quatro categorias analíticas são indissociáveis, trabalham sempre juntas.

Uma dada estrutura social e econômica possui seus processos intrínsecos que demandam funções a serem cristalizadas em formas espaciais (CORRÊA, 2002, 77).

Um exemplo desta análise pode ser compreendido quando vemos alguns centros urbanos, outrora residência de uma elite, transformados em habitações para uma classe de baixa renda. Esta elite se retira do centro (por conflitos sociais - a violência, por exemplo) e vai para bairros ou cidades mais distantes. Esta velha forma espacial vai ganhar novas funções - de fornecer habitação mais barata para a classe trabalhadora e ainda fornecer remuneração para esta classe possuidora desta formas já deterioradas. Estas novas funções resultam de um processo, que é o centro da estrutura sócio-econômica capitalista, ou seja, o de acumular mais capital via construção de novos bairros para a morada de sua elite; a de extrair uma renda de suas antigas moradas; a de baratear o custo da força de trabalho via construções precárias e próximas aos centros produtivos e ainda a de garantir a reprodução das classes dominante e trabalhadora.

\section{7 - Outras concepções de espaço geográfico}

O espaço geográfico pode ser entendido como um conjunto de elementos naturais e de objetos humanos construídos e distribuídos pela superfície de nosso planeta. Este espaço não é uma extensão preexistente, mas sim constituído pelas coisas que se transformam pela ação humana em objetos geográficos:

...os objetos tomam o lugar das coisas. No princípio, tudo eram coisas, dádivas da natureza, quando utilizadas pelos homens a partir de um conjunto de intenções sociais, passam, também, a ser objetos. Assim a natureza se transforma em um verdadeiro sistema de objetos e não mais de coisas (SANTOS, 2002b, p.65).

Os objetos geográficos são os componentes fundamentais do espaço geográfico e tem uma finalidade. São coisas construídas pelo ser humano, que tem objetivos e são produzidos com intenções predeterminadas. Os elementos da natureza (em uso, humanizados, como um rio que vira meio de transporte) e os objetos sociais são os constitutivos do espaço geográfico (OLIVA, 1999). O espaço geográfico é um espaço produzido, construído pela sociedade humana - um espaço social. 
Para SANTOS (2002b, p. 63) "o espaço é formado por um conjunto indissociável, solidário e também contraditório, de sistemas de objetos e sistemas de ações".

A representação da organização dos objetos geográficos sempre esteve presa a métricas "rígidas", tradicionalmente relacionadas ao espaço absoluto, isto é, ao espaço preexistente, que contém as coisas, que ocupam e estão no espaço. Já nos referimos ao espaço absoluto em página anterior, onde este conceito tem origens na Física de Isaac Newton (1642-1727)

O espaço absoluto, por sua natureza, sem nenhuma relação com algo externo, permanece sempre semelhante e imóvel (NEWTON, 1979, p. 8).

ou

Espaço absoluto, também chamado cartesiano, é um contêiner de coisas e eventos, uma estrutura para localizar pontos, trajetórias e objetos (CONCLELIS apud MONTEIRO, CÂMARA. ALMEIDA, 2007, p. 44).

ou

Espaço euclidiano é aquele construído segundo uma métrica euclidiana...Esse espaço supõe a continuidade (nada de lacuna) e a contigüidade (nada de ruptura), mas também a uniformidade (métrica constante em todo ponto). É um caso particular do que em matemática denomina-se como "espaço métrico" (LÉVY, 2003e. p.351).

Usar o conceito de espaço geográfico em Geografia leva a identificar o espaço como "palco dos acontecimentos e das intervenções humanas e também, da dinâmica natural. Como palco ele é externo à sociedade e da própria natureza e, portanto, dentro dessa lógica fica difícil falar em espaço produzido, espaço humano" (FONSECA, 2004, p.36).

Esta concepção predominou na geografia tradicional, na regional, desenvolvida por Hartshorne, na "Nova Geografia" e permanece como conceito dominante utilizado pela Geografia.

Outra concepção de espaço - o espaço relativo - irá surgir com o que podemos chamar de renovação da Geografia, em autores como David Harvey, Milton Santos e Jacques Lévy. Tem sua origem no pensamento de Gottfried Wilhelm Leibniz (1646-1716):

Quanto a mim, deixei assentado mais de uma vez que, a meu ver, o espaço é algo puramente relativo, como o tempo; a saber, na ordem das coexistências, como o tempo na ordem das sucessões. De fato, 
o espaço assinala em termos de possibilidade uma ordem das coisas que existem ao mesmo tempo, enquanto existem junto, sem entrar em seu modo de existir. E quando se vêem muitas coisas junto, percebe-se essa ordem das coisas entre si (LEIBNIZ, 1979. p.177 - grifos nossos).

Com esta concepção de espaço - relações entre coisas coexistentes formando uma rede - Leibniz rejeita a concepção de espaço absoluto e trava com Samuel Clarke - discípulo de Newton - um intenso debate. Na quinta carta enviada a Clarke, Leibniz resume a sua posição:

Mostrarei aqui como os homens vieram a formar a idéia de espaço. Eles consideram que existem muitas coisas ao mesmo tempo e observam nelas uma certa ordem de coexistência, segundo a qual a relação de uma coisa com outra é mais ou menos simples. Essa ordem é a situação ou distância delas. Quando sucede a uma dessas coisas coexistentes modificar sua relação entre si, e quando uma coisa recém-chegada adquire com as outras a mesma relação que a primeira tinha com elas, dizemos que ela entrou no lugar da primeira; a essa mudança damos o nome de movimento daquele corpo, sendo o movimento a causa imediata da mudança. E embora muitas, ou até todas as coisas coexistentes, devam mudar de acordo com certas regras conhecidas de direção e velocidade, é sempre possível determinar a relação de situação que cada coexistente adquire com respeito a todos os outros coexistentes e determinar, até mesmo, a relação que qualquer outro coexistente teria com este, ou que este teria com qualquer outro, se não se houvesse modificado, ou caso se houvesse modificado de outra maneira. E, supondo ou imaginando que entre esses coexistentes haja um número suficiente que não tenha passado por mudanças, podemos dizer que os que têm com esses existentes fixos a relação que antes os outros tinham com eles ocupam agora o lugar antes ocupado por esses outros. Espaço é aquilo que abarca todos esses lugares. (LEIBNIZ6 apud JAMMER, 2010, p.153-154 - grifos nossos)

Leibniz concebe o mundo como dinâmico, oposta à formulada por Descartes que tinha uma concepção geométrica e mecânica. (CHAUí, 1979).

Para o físico brasileiro Mário Schenberg, Leibniz introduz a

idéia do espaço e do tempo como estruturas de ordem, o que é importante para entendermos relatividade...Para Leibniz, o espaço é uma estrutura de ordem de simultaneidade e o tempo é uma estrutura de ordem de sucessão. (SCHENBERG, 1984, p. 84 - grifos nossos)

O espaço assim não é um vazio que preexiste, mas sim constituído pelas coisas em relação, "uma estrutura de ordem de simultaneidade". Na geografia o seu

\footnotetext{
${ }^{6}$ A Collection of Papers which Passed between the Late Learned Mr. Leibniz and Dr. Clarke . Londres, 1717, p. 213. Esta mesma citação encontra-se também em LEIBNIZ, 1979. p.201-202, com pequenas diferenças de tradução.
} 
uso leva "a entender os objetos geográficos em relação como constitutivos do espaço geográfico. Portanto, uma cidade não está no espaço, ela é espaço geográfico" (FONSECA, 2004, p.36)

Para Lévy, o espaço geográfico é:

A.Uma das dimensões da sociedade, correspondendo ao conjunto das relações que a distância estabelece entre diferentes realidades.

B. Objeto social definido pela sua dimensão espacial. Um espaço é caracterizado no mínimo por três atributos: a métrica, a escala e a substância. Uma realidade espacial é frequentemente híbrida, ao mesmo tempo material, imaterial e ideal. (LÉVY, 2003d, p. 325)

O espaço geográfico é, portanto, a dimensão estabelecida pelo conjunto de relações sociais que ocorrem simultaneamente e mediadas pela(s) distância(s) que aproximam ou afastam realidade(s) diferentes ou "iguais" (LÉVY, 2003d). O espaço como objeto social é definido por sua dimensão espacial caracterizada por três componentes: a métrica - que é o "modo de medir e de tratar a distância" (LÉVY, 2003g, p. 607), a escala - que define o tamanho do espaço ["define limiares de descontinuidades na medida das distâncias" (PONCET, 2008, p.8 - tradução nossa)] e a substância - "componente não espacial de uma configuração espacial" (LÉVY, 2003h, p.880 - tradução nossa). A substância é "que decide o tipo de distância que corresponde a tal fenômeno" (PONCET, 2008, p.8 - tradução nossa) e que "pode ser os homens, os agricultores, as vacas, as televisões ou qualquer outra realidade." (BEAUDE, 2008, p.19 - tradução nossa).

Nesta concepção a métrica é um modo social de medir as distâncias. Na concepção de espaço absoluto a métrica é euclidiana e aqui o espaço não é geométrico euclidiano, pois sendo "uma das dimensões da sociedade", ou como "elemento transversal das relações sociais, cria distâncias cujas métricas não correspondem às métricas euclidianas" (FONSECA, 2004, p.40)

As distâncias geográficas estão presas às métricas do tipo metros, quilômetros (FONSECA; OLIVA, 1999) - utilizadas principalmente nas representações cartográficas - o mapa. Representações outras que não as métricas euclidianas são o grande desafio para a cartografia-geográfica. 


\section{3 - O MAPA, A COREMÁTICA, O URBANO E A DENSIDADE}

Nos capítulos anteriores trabalhamos o mapa como representação do espaço geográfico e, posteriormente, fizemos uma breve revisão bibliográfica sobre qual(is) tipo(s) de espaço geográfico a Geografia teorizou.

O propósito agora é relacionar estas discussões com o recorte espacial que assumimos como representativo para testar nossas representações: o mapa dasimétrico, as anamorfoses e a coremática.

O recorte espacial é a metrópole paulistana, portanto o espaço urbano deverá ser contemplado em nossas representações. O fio condutor como fenômeno a ser trabalhado será a densidade.

Como exposto no capitulo anterior, a concepção de qual espaço geográfico a geografia trabalhou e trabalha [ou simplesmente não trabalha(ou)] é diversa. A nossa postura é de que o espaço geográfico é compreendido, genericamente, como uma dimensão da sociedade. Foi este entendimento que norteou as nossas reflexões e será com esta postura que pretendemos avançar. É a dimensão estabelecida pelo conjunto de relações sociais que ocorrem simultaneamente e mediadas pela(s) distância(s) que aproximam ou afastam realidade(s) (LÉVY, 2003d) diferentes ou "iguais".

Estas novas reflexões sobre o espaço geográfico começam a influenciar a cartografia. Lévy (2004 e 2008) nos aponta que depois dos trabalhos inovadores sobre as linguagens gráficas - a semiologia gráfica - estreitam-se atualmente as teorias sobre o espaço e o fazer cartográfico. Novas ferramentas matemáticas e estatísticas, as anamorfoses, recursos novos em SIGs, a modelização gráfica - a coremática - são esforços para tentarmos sair do esquema euclidiano. É nessa renovação e estreitamento do espaço geográfico e cartográfico que construiremos uma Cartografia-Geográfica, isto é, em novas bases conceituais e com novas relações e funções que o mapa tem para a Geografia. Bertin já colocava que o mapeamento das "referências naturais... úteis aos homens acaba de ser terminado.... Não temos mais uma "Terra Incógnita"” (BERTIN, 1988, p. 45). Essa função inicial dos mapas está cumprida. O desafio atual é buscar representações cartográficas ou pós-cartográficas que sejam possíveis de apreender os espaços cada vez mais complexos, diversos e velozes da sociedade humana atual. 


\section{1 - Um pouco mais de mapas}

Adotamos como método, como orientador de nossas reflexões, construções e análises cartográficas e pós-cartográficas - a coremática - um entendimento de que o mapa é uma linguagem construída a partir de uma imagem analógica do espaço geográfico. Baseado em Lévy (2003b, p.128), conforme apresentado anteriormente, os mapas devem, ou deveriam contemplar pelos menos alguns desses elementos:

1.Qual o espaço de referência?

2.Qual a(s) escala(s) cartográficas?

3.Qual o princípio que norteou a transposição analógica do espaço referente para o espaço no mapa?

4.Qual, ou quais métricas foram utilizadas?

5.Quais "temas", qual ou quais substâncias foram contempladas?

6.Qual semiologia de representação gráfica foi empregada?

Outra orientação de nossas reflexões foi o entendimento de que o mapa passa por uma sequência lógica de transformações. Transformação, palavra de origem latina, que significa ação de transformar, mudança de forma (CAUVIN et al, 2007). É uma mudança de forma pela qual o mapa passa, desde a primeira representação do terreno até o mapa final em seus mais variados formatos. É uma sucessão de transformações, de famílias de transformações. Chamada de cartografia transformacional, segundo Cauvin (2007), foi iniciada por Waldo Tobler em 1961 e desenvolvida por Clarke (1990) nos EUA. Na França, por Sylvie Rimbert e a própria Cauvin. Na figura 3 mostramos a família de transformações segundo Cauvin (2007).

A primeira transformação [T1] é a primeira etapa, a primeira tentativa de espacializar um fenômeno que queremos representar, por exemplo, um fenômeno bem "simples" - o planeta Terra! Ele não está em uma métrica euclidiana - ele é transformado para uma métrica bidimensional, coerente com a geometria euclidiana. É um campo, uma especialização profissional atual da cartografia matemática, dos engenheiros cartógrafos, topógrafos, agrimensores... É uma especialidade que os 
geógrafos perderam já faz algum tempo [não significa que não devam conhecê-la e mesmo a dominarem atualmente].

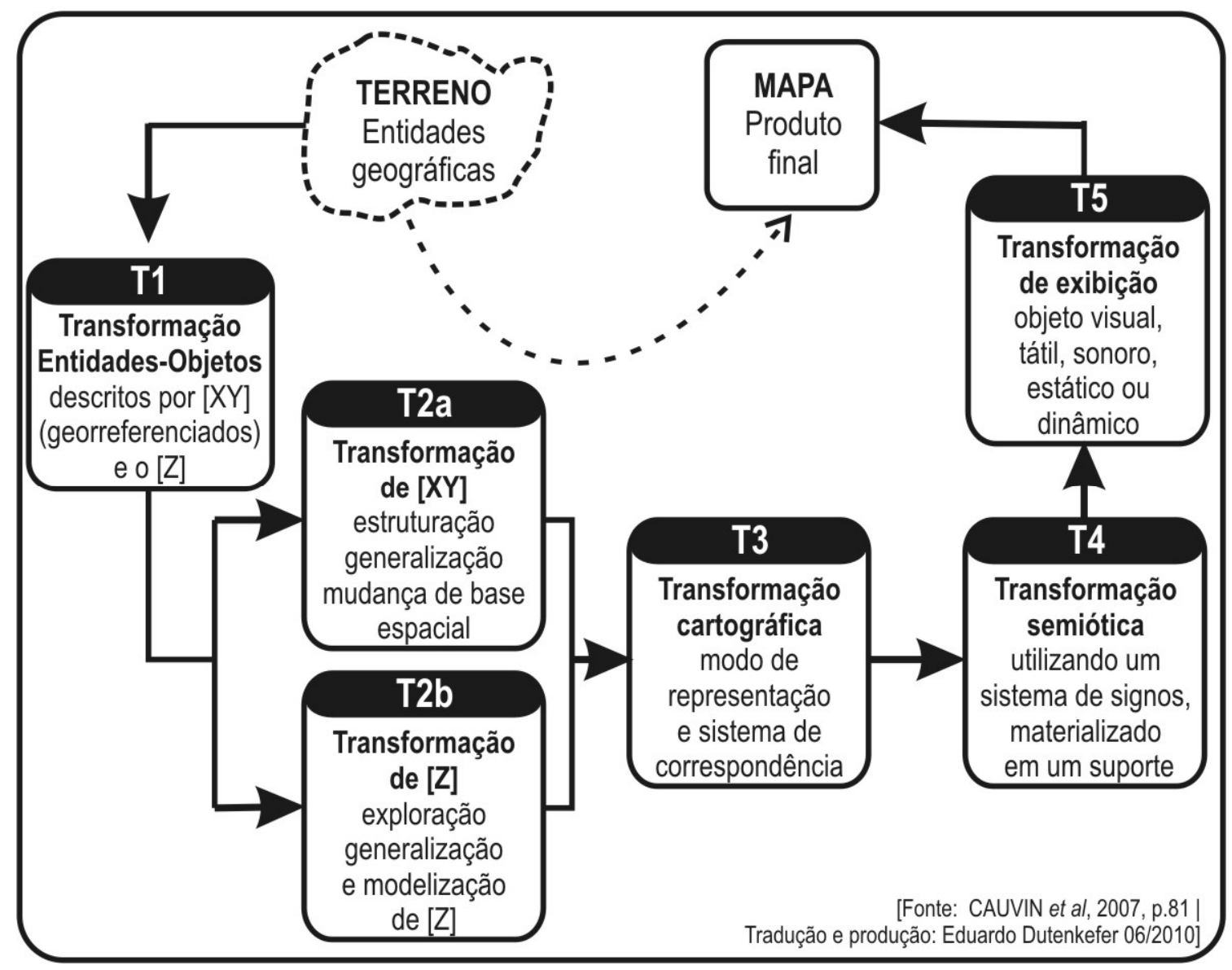

Figura 3 - Família de transformações

Um pequeno parênteses...

[Paul Claval (2002) descreve como perdemos esta competência. Foi a partir da metade do século XVIII que a Geografia, como a conhecemos, começou a existir. Foi com os avanços de procedimentos astronômicos para determinar a longitude e com a invenção do cronômetro marítimo que a Geografia de Erastóstenes e de Ptolomeu, que tinham como objetivo a determinação de coordenadas dos lugares na superfície de nosso planeta, para elaborar representações cartográficas, deixou de existir. Os geógrafos desta época ficaram sem emprego! Não foi suficiente serem eruditos na descrição astronômica do mundo - a cosmografia [do grego kosmos+graphein] e trabalharem em bibliotecas. O levantamento de mapas, o trabalho em campo tornou-se campo da engenharia. Perdemos $50 \%$ de nossas competências. O que fazer? Adotar a perspectiva do cientista natural - dedicar-se a descrição do mundo. Alexandre Von Humboldt é o nosso expoente dessa 
reorientação. Preocupar-se com o espaço - mesmo que seja no sentido geométrico, matemático deixa de fazer sentido. Deixaremos esta primeira etapa de transformação [T1] nas mãos de "competentes". Assumiremos este padrão como a "verdadeira" representação(?) de nossa Terra. A reflexão epistemológica nesta época não é a preocupação de futuros desempregados. Compartilhar o pensamento, os modelos de especialistas das ciências físicas ou naturais é a saída. Tornamo-nos cientistas naturalistas!] - fim do colchetes!

A segunda transformação [T2] compreende duas transformações [T2a e T2b] paralelas ou sucessivas que irão concretizar materialmente os objetos geográficos em objetos cartográficos e teremos um mapa de base, o nosso fundo de mapa. A primeira [T2a] é feita em duas fases. A primeira corresponde a uma transformação de escala dos localizantes espaciais [XY] necessária para uma redução de seu tamanho, implicando uma generalização dos diversos traçados, a sua estruturação. A segunda fase é reservada a uma mudança eventualmente de base espacial em função dos localizantes espaciais [XY] e dos objetivos do mapa alteração de uma projeção cartográfica, por exemplo.

O segundo conjunto de transformações [T2b] é reservado aos atributos, aos temas, ao [Z] - a nossa substância - que orientará e revelará os traços essenciais do fenômeno que queremos representar. É uma etapa importante, pois é nessa fase que iremos estruturar, organizar, classificar, modelizar os dados temáticos para construirmos mapas compreensivos. É uma etapa demorada, pois temos que encontrar os dados, avaliá-los, analisar se são relevantes para o nosso estudo, eventualmente tratá-los estatisticamente e por fim deixá-los os mais claros possíveis para o nosso leitor/visualizador final do mapa não ser ludibriado/enganado.

A terceira e a quarta família de transformações [T3 e T4] constitui o centro, o coração da elaboração cartográfica, pois implica uma etapa em que estaremos concebendo, formulando e visualizando o mapa criado. A transformação [T3] estabelece o modo que iremos representar o produto final e [T4] - a transformação semiótica - que propõe um sistema de signos que materializam o mapa e oferecem as chaves de leitura do mesmo. Ainda segundo Cauvin (2007) podemos desmembrar [T3] em duas grandes transformações cartográficas, a de estado e a de posição - ver figura 4. São duas diferentes formas de trabalhar com os localizantes espaciais [X, Y] e o "atributo" [Z]. Basicamente a transformação de estado, altera o 
"estado" do mapa, isto é, dependendo do [X,Y,Z] trabalhado, alteraremos a sua mensagem, o seu significado. Aplicando por exemplo [Z] nos localizantes [X,Y] teremos mapas do tipo coropléticos e dasimétricos que fazem parte de nossos interesses. Se, ao contrário o "atributo" [Z] for o "determinante" sobre os localizantes $[X, Y]$ ou em termos da linguagem matemática $x=f[Z]$ e $y=g[Z]$ - os localizantes serem função de [Z], teremos o que Cauvin nomeia de "transformação cartográfica de posição", a nossa Anamorfose.

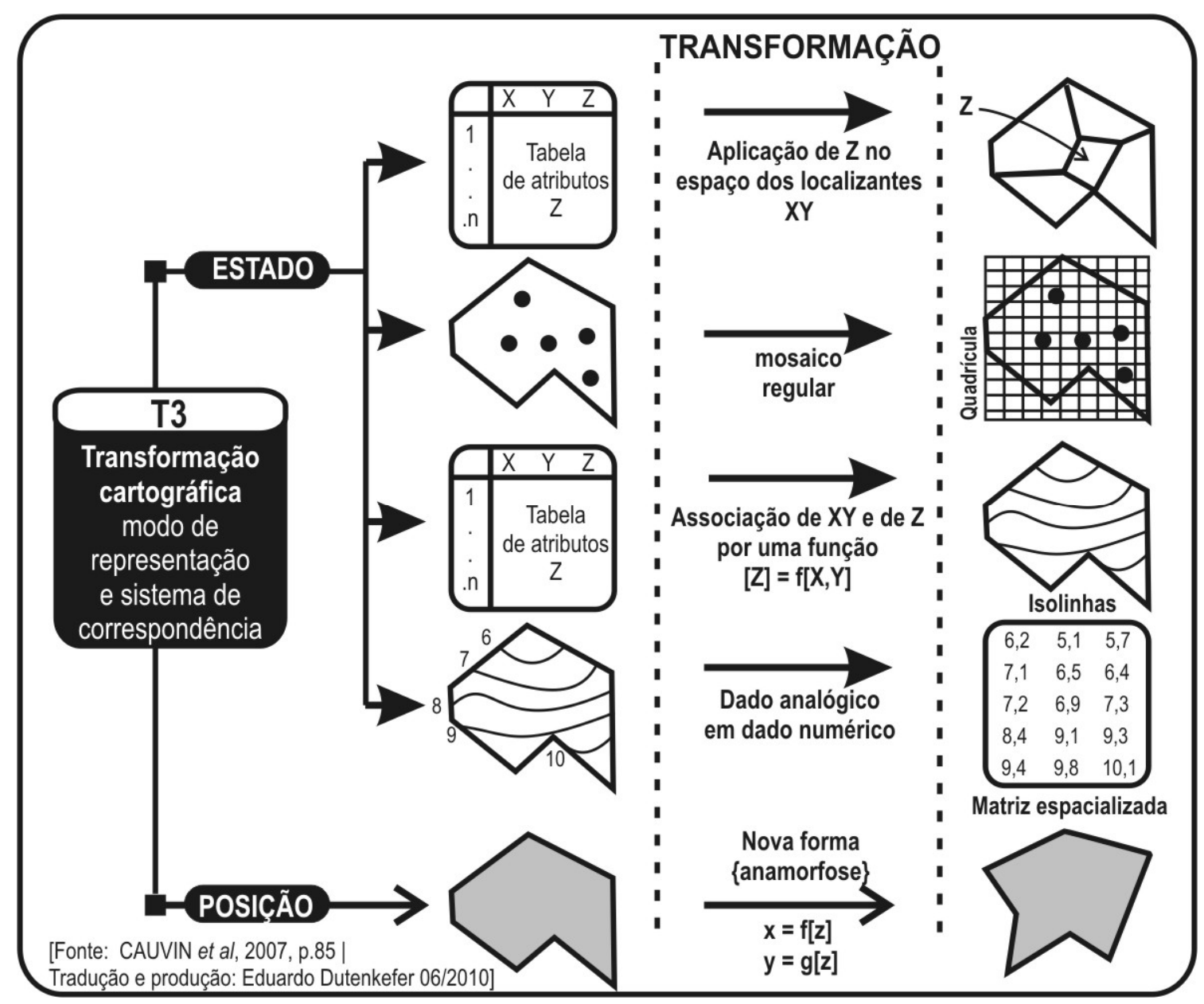

Figura 4 - Transformações cartográficas

Finalmente na etapa T5 o produto mapa é materializado para exibição, visualização, reprodução e difusão em diferentes meios.

Pensando no mapa como linguagem, podemos também utilizá-la como norteadora de nosso método. Lévy (2004) diferencia dois conjuntos de mapas (figura 5). Os "mapas à leitura não espacial" e os "mapas à leitura espacial". Os mapas que não são adequados a uma leitura espacial, podemos tratá-los como uma simples tabela de dados ou como um simples cruzamento de duas coordenadas com uma 
outra informação - topônimos, cotas hipsométricas, etc. Se o mapa privilegia uma leitura espacial, instantânea e global teremos de fato um modelo gráfico propício às análises da dimensão da sociedade. Neste sentido o mapa coroplético e dasimétrico que iremos apresentar se enquadrariam nesta vertente, isto é, são mapas que nos remetem a uma leitura espacial, possuem um fundo convencional, utilizam métricas euclidianas, portanto representativos do espaço geográfico absoluto, euclidiano. Já a anamorfose, que também é um mapa para uma leitura espacial, tem um fundo de mapa mais significativo, não convencional, com métricas outras que não a euclidiana, portanto representativo do espaço geográfico no sentido relativo.

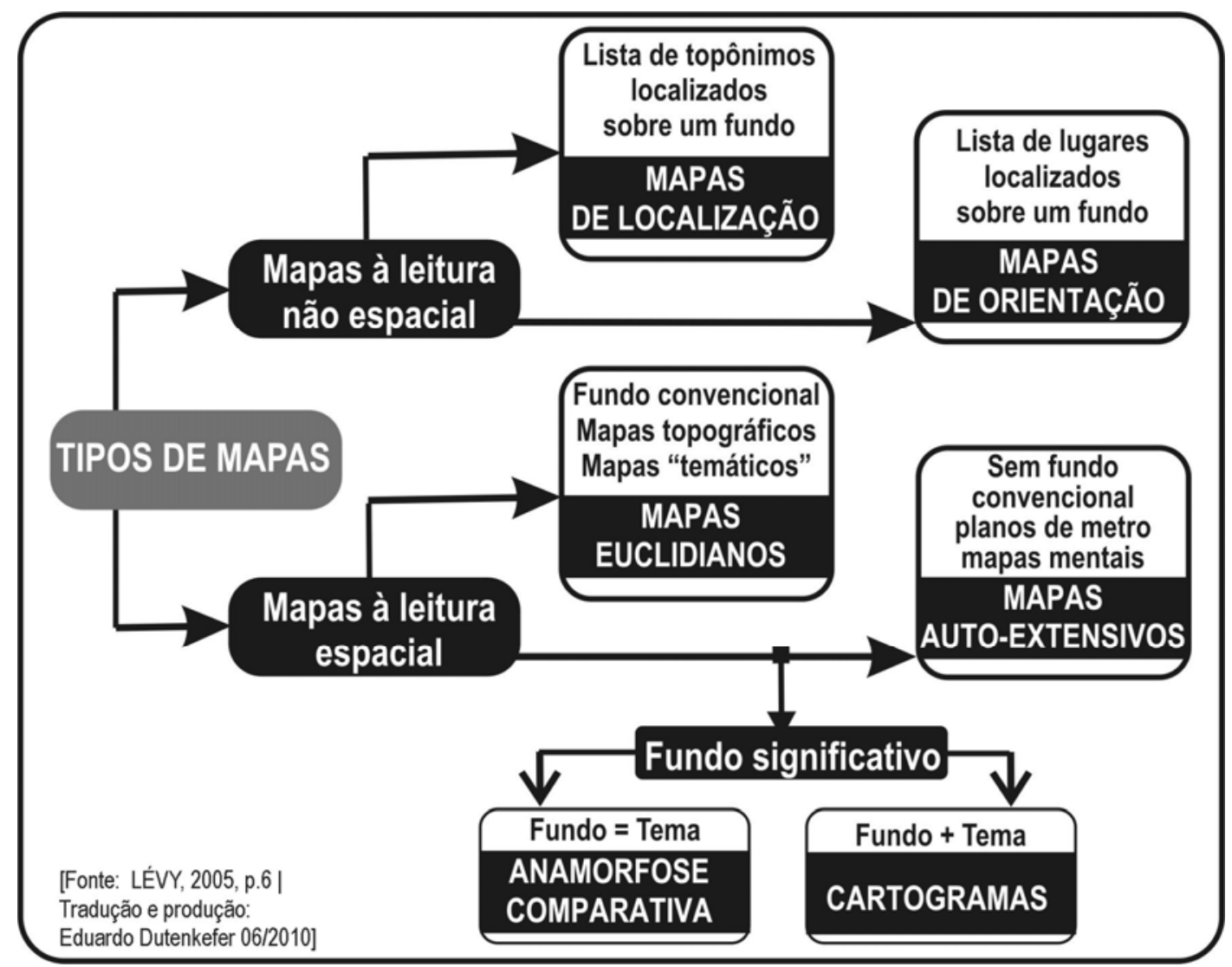

Figura 5 - Tipos de mapas privilegiando uma diferenciação de suas leituras espaciais

Temos assim 3 [três] reflexões, três eixos que auxiliam na avaliação e análise do mapa dasimétrico [capítulo 4], do mapa em anamorfose [capítulo 5] e da modelização gráfica [capítulo 6]:

Eixo 1 [um] => Os 6 [seis] elementos que o mapa deveria contemplar. [pg. 35]

Eixo 2 [dois] => Tratar o mapa e a modelização gráfica como uma sequência lógica de transformação; [pg. 36,37 e 38] 
Eixo 3 [três] => "Mapas à leitura não espacial" e os "mapas à leitura espacial". [pg. 39 e 40].

\section{2 - A modelização gráfica - coremática}

No capítulo 6 iremos trabalhar com mais detalhes a modelização gráfica apoiada em reflexões da coremática desenvolvida por Roger Brunet. Na década de 1980, Brunet cria o neologismo corema [chorème] e o define como o elemento estruturante primordial do espaço geográfico. Coremática, por sua vez, será a "gramática" dos Coremas, a ciência interpretativa das estruturas espaciais elementares (BRUNET, 1987, 1993).

Neste tópico é importante salientar que a modelização gráfica a partir de Coremas é "uma escritura de modelos geográficos sob forma de figuras" estreitamente relacionada e próxima com a cartografia, mas que não se confundem. Ela é geográfica, pois se refere às formas espaciais produzidas na apropriação do espaço pela sociedade. Brunet oferece com a coremática a possibilidade da representação gráfica de uma análise espacial. "Ele conseguiu descolar do simples mapa de ilustração para levar o mapa em direção a uma síntese reflexiva" (FONSECA, 2004, p.17)

A modelização gráfica trabalhada aqui vai no sentido de uma póscartografia. Ela será um método que utilizará os diversos mapas produzidos nesta pesquisa - o dasimétrico com métricas euclidianas - e as anamorfoses - com outras métricas - para compor uma síntese gráfica final que expresse as estruturas e dinâmicas da metrópole paulista. É o mapa revelando estruturas, organizações de um território. Na lógica das transformações espaciais seria mais uma etapa após os diversos mapas serem concluídos, sofrerem novas transformações espaciais.

A modelização gráfica reforça os esforços de renovação das bases conceituais para uma Cartografia-Geográfica. Mesmo não sendo um mapa no sentido apontado por nós na página 18 - Figura 2 - o mapa como uma intersecção de dois espaços - é uma alternativa de representação do espaço geográfico que pode ser produto de mapas com fundo euclidiano ou não. Poderíamos talvez caminhar no sentido de uma carta-coremática ou um mapa-coremático? Os coremas exprimem lógicas de base que estruturam os espaços das sociedades (GRATALOUP, 2003a), ou seja, lógicas que a distância entre objetos geográficos 
podem proporcionar mais ou menos interações sociais; coexistência com diversidades ou não de vitalidades urbanas; divisões, fragmentações e oposições espaciais; revelam hierarquias e dissimetrias sociais, econômicas; políticas e culturais; exprimem também expansões, retrações, tempos passados e perspectivas futuras de dinâmicas espaciais. Fortes candidatos para tornarem-se "mapas" à leitura espacial [mapas-coremáticos ou mapas modelos?] sem um fundo de referência convencional - mapas auto-extensivos segundo o nosso esquema apresentado na figura $5-$ pg. $39 ?$

\section{3 - O urbano e a sua densidade}

Outra reflexão necessária nesta pesquisa é sobre o recorte espacial escolhido, o fenômeno a revelar, qual(is) substância(s), nosso "fio condutor", queremos representar em mapas e em modelizações gráficas.

Nossas argumentações são orientadas no sentido de que o espaço geográfico é uma dimensão da sociedade. Dimensionar esta sociedade usando o mapa e/ou uma síntese gráfica - coremática - como um dos principais instrumentos do cientista espacial social - o geógrafo - pode ser ao mesmo tempo amplo e restrito, em escala global, regional e/ou local. Realizamos aqui, nesta pesquisa, um recorte, um ajuste de escala, uma incisão cirúrgica, nesta dimensão social e focamos nosso olhar "cartogeográfico" no território da metrópole paulista. Uma metrópole que revela o fenômeno urbano, evidenciando a cidade em particular. Um lugar, um espaço [no seu mais amplo sentido] que fascina e que pode oferecer fenômenos da simultaneidade, [lembram do espaço de Leibniz?] da acessibilidade, da mobilidade e fundamentalmente da densidade, que caracterizam uma cidade, um 'locus' urbano.

Lévy (2004) alerta que fenômenos densos foram e são mal representados em mapas. A cidade como o lugar de concentração de humanos, de equipamentos culturais, sociais, de densidades e diversidades de um modo de vida típico de nosso mundo social - o urbano. Densidades geralmente "submersas pelas extensões vazias" representadas em mapas topográficos. Cidades representadas como pontos,

como círculos. Apenas localizações de um fenômeno extremamente rico e complexo. Mesmo mapas topográficos em grandes detalhes - (escalas cartográficas na ordem de 1:5000 a 1:2000) representam fundamentalmente localizações de 
objetos geográficos que não revelam "a complexidade e a interpenetração dos espaços, subjetivos e objetivos, materiais e ideais" (LÉVY, 2004, p. 158).

Representar este espaço urbano é um desafio que a Cartografia-Geográfica tem como tarefa contemporânea. Escolhemos este espaço para ser representado em mapas e modelos coremáticos por meio de uma característica fundamental que evidencia seu caráter urbano: a densidade.

A definição de densidade em nossa língua deriva do latim - densitas - e como substantivo feminino dá o sentido da qualidade do que é denso, que por sua vez vem do latim densus - compacto, espesso - e também a idéia de "grau de concentração de pessoas num determinado espaço"7, conteúdo intenso, profundo São sentidos, reflexões que nos remetem à cidade, ao lugar candidato das concentrações do gênero humano e de suas realizações, façanhas e desilusões. É um espaço qualificado como urbano que possibilita intensas relações sociais. Cidade como "conjunto de máxima concentração e de máxima diversidade de objetos geográficos que favorece e acomoda grandes contingentes populacionais em distância mínima e atua como estimuladora de relações societais" (OLIVA, 2003, p. 73).

$\mathrm{Na}$ Geografia, a noção de densidade tradicionalmente sempre esteve associada à ideia de densidade de população, ou seja, como um cálculo de número de habitantes por unidade de superfície (LÉVY, 2003c). Segundo Beaude (2008) dois importantes dicionários de Geografia francesa - de Pierre George \& Fernand Verger, de 1996 e de Yves Lacoste, de 2003 - remetem o vocábulo a definição de densidade como sendo referente à densidade de população. É em um terceiro, de Roger Brunet e outros, que a densidade para a Geografia é definida como sendo "a razão de um número de objetos a uma superfície definida: habitantes por quilômetro quadrado, vacas por hectare" (BRUNET et all, 1993, p.148, tradução nossa). É um valor relativo em algum espaço considerado. É uma noção, um conceito que depende da superfície relacionada. Portanto, podemos ampliar o leque de objetos geográficos no numerador e no denominador desta relação.

Densidade é a "razão entre a massa de uma substância localizada num espaço e a dimensão deste espaço" (LÉVY, 2003c, p.237, tradução nossa). Mais

\footnotetext{
${ }^{7}$ iDicionário Aulete da língua portuguesa. Disponível em:

http://aulete.uol.com.br/site.php?mdl=aulete_digital - acesso: 28/06/2010
} 
que uma simples razão aritmética de divisão de um numerador, com um número de habitantes, por um denominador, com um número, uma unidade de superfície, devemos apreendê-la como uma relação entre um componente não espacial de um espaço - uma substância - com uma extensão de um espaço considerado, isto é, com alguma referência que podemos qualificar e quantificar, portanto que possui uma escala geográfica e seja possivelmente representável em uma escala cartográfica. Temos que estabelecer formas de dimensionar a sua métrica e criar possibilidades de representar esta densidade em um mapa ou em uma modelização gráfica. É o que tentaremos refletir, produzir e testar com os mapas dasimétricos, mapas em anamorfose, cartogramas em anamorfose e modelização gráfica nos próximos capítulos. 


\section{0 - MAPAS DASIMÉTRICOS}

\section{1 - Introdução}

A representação da organização dos objetos geográficos sempre esteve presa a métricas "rígidas", tradicionalmente relacionadas ao espaço absoluto, isto é, ao espaço preexistente, que contém as coisas, que ocupam e estão no espaço. As distâncias geográficas estão presas às métricas do tipo metros, quilômetros (FONSECA; OLIVA, 1999) - utilizadas principalmente em representações da cartografia sistemática. Representações outras que não as métricas euclidianas e mais focadas no conteúdo que vai ser representado são possibilidades mais ligadas ao que tradicionalmente chamamos de cartografia temática. Cartografia esta que é:

"a ciência da representação e do estudo da distribuição espacial dos fenômenos naturais e sociais, suas relações e suas transformações ao longo do tempo, por meio de representações cartográficas modelos icônicos - que reproduzem este ou aquele aspecto da realidade de forma gráfica e generalizada." (SALICHTCHEV, 1973 apud MARTINELLI, 1991, p.35)

E que:

... não é simplesmente uma técnica, indiferente ao conteúdo que está sendo veiculado. Se ela pretende representar e investigar conteúdos espaciais por meio dos citados modelos não poderá fazêlo sem o conhecimento da essência dos fenômenos que estão sendo representados (MARTINELLI, 1991, p.35, grifos nossos).

Utilizar a técnica dasimétrica na elaboração e confecção de mapas temáticos é uma tentativa de superar esta "rigidez", mesmo não superando as métricas tipicamente euclidianas. A técnica dasimétrica aperfeiçoa, aprimora os chamados mapas coropléticos. A representação de uma distribuição espacial por meio de um mapa coroplético é feita assumindo que o valor do dado que queremos representar é constante dentro de cada corograma, isto é, dentro de áreas pré-definidas, geralmente baseadas em divisões territoriais do tipo política ou administrativa.

Para tentarmos uma representação cartográfica mais "realista", que supere os limites mais "rígidos" da técnica coroplética, a técnica dasimétrica nos oferece a oportunidade de estabelecer relações outras que não estejam confinadas somente à contornos pré-estabelecidos. Na técnica dasimétrica as áreas onde temos dados quantitativos estatísticos são subdivididas em áreas de homogeneidade relativa, baseando-se em informações complementares. Está técnica permite desagregar e posteriormente agregar dados/informações espaciais. 


\section{2 - Histórico}

Segundo MACEACHREN (1979), ROBINSON (1955), MAANTAY, MAROKO \& HERRMANN (2007) e PETROV (2008), em 1833, George Poulett Scrope ${ }^{8}$ geólogo e economista político britânico - utiliza uma técnica dasimétrica rudimentar em um mapa da população do mundo, distinguindo e traçando com linhas, com espessuras variáveis, extensões completamente povoadas, sub-povoadas e ainda não povoadas da Terra. Em 1837 Henry Drury Harness, (1804-1883) - engenheiro ferroviário britânico - publica no "Atlas to Accompany the Second Report of the Railway Commissioners, Ireland. Dublin:", o primeiro mapa de densidade populacional da Irlanda considerando os dados do censo de 1831 e os fatores naturais do país, conforme observam ROBINSON (1955), MACEACHREN (1979), PALSKY(1998) e citados por CAUVIN (2007) e PETROV (2008) (figura 6). Neste mapa, em algumas áreas os limites da classe da densidade não carregam nenhuma relação com os limites administrativos, que deve ser esperado quando a técnica dasimétrica é utilizada. Em outros lugares, entretanto, os limites da classe coincidem claramente com os limites administrativos, como é usual quando a técnica coroplética é usada. Além disso, em determinados exemplos, os limites são irregulares e parecem não seguir limites administrativos. (ROBINSON, 1955, p.444).

Harness, em seu relatório à comissão ferroviária da Irlanda, escreve que a "sua intenção era produzir um mapa das densidades da população limitadas aos limites das unidades administrativas irlandesas, mas que os comissários da companhia solicitaram um maior detalhe suprimindo as áreas montanhosas e pantanosas", i é, não habitadas (ROBINSON, 1955, p.444 - tradução nossa). Isto mostra claramente um método dasimétrico empregado.

\footnotetext{
${ }^{8}$ Anteriormente George Julius Thomson (1797-1876). Oxford Dictionary of National Biography. Disponível em: http://www.oxforddnb.com/index/101024956/. Acesso: 10/09/2008
} 


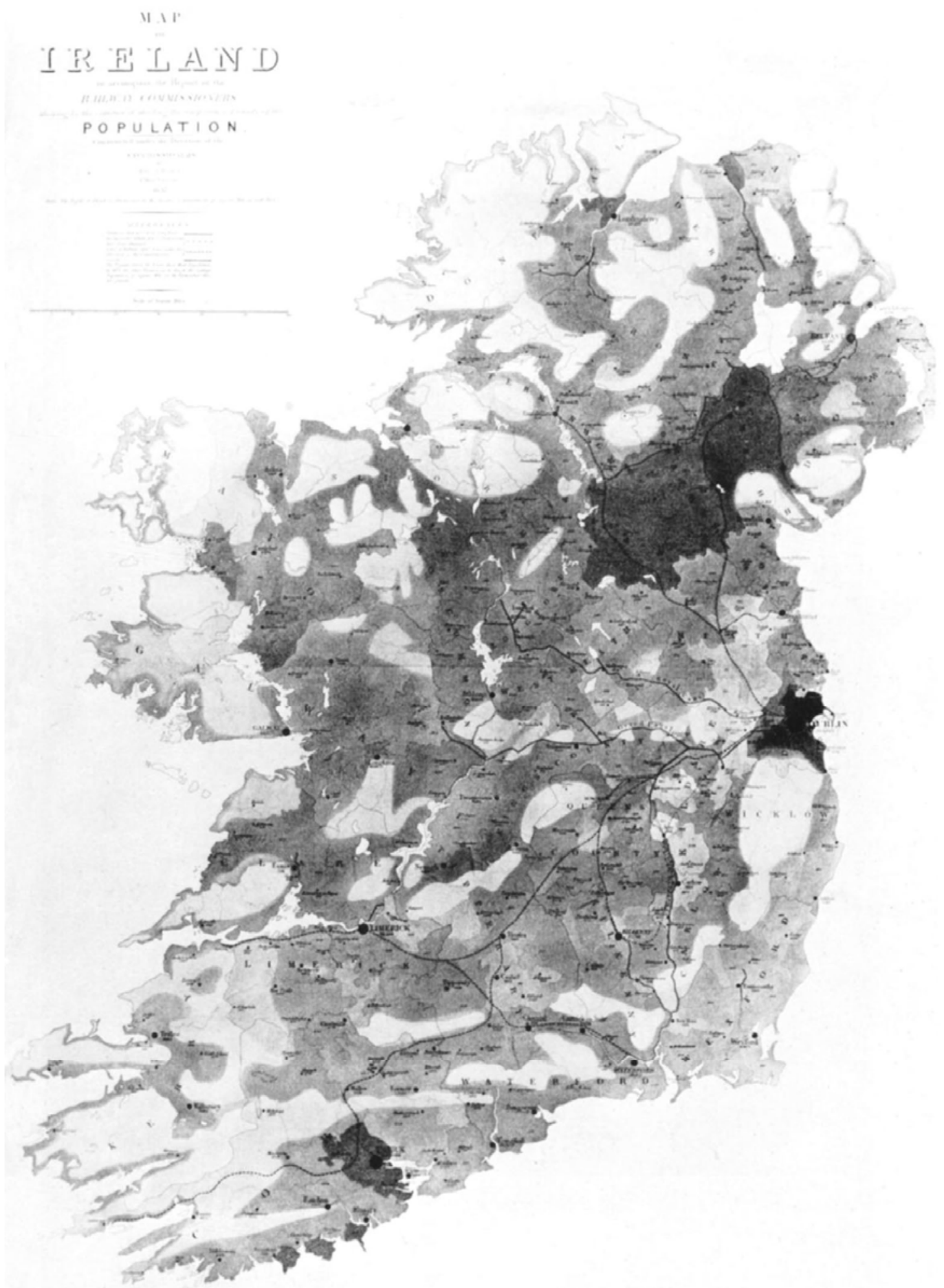

Harness' Population Map, I837. Original, I inch to Io miles. Brit. Mus.

Figura 6 - Mapa de População da Irlanda de HARNESS de 1837 (ROBINSON. 1955, p. 449)

Vários autores [BIELECKA (2005); FABRIKANT (2003); MAANTAY, MAROKO \& HERRMANN (2007); MENNIS e HULTGREN (2006)] apontam que o 
termo dasymetric e a técnica foram primeiramente utilizados pelo geógrafo e estatístico russo Peter (Petr Petrovich) Semenov-Tyan-Shansky (1827-1914), contudo, o artigo de Andrey N. Petrov (PETROV, 2008) parece esclarecer esta pequena confusão: Kamenetsky ${ }^{9}$, (1930 apud Petrov, 2008) escreve que foi Benjamin (Veniamin Petrovich) Semenov-Tian-Shansky - filho de Peter SemenovTyan-Shansky - quem primeiro introduziu o conceito de dasimétrico em seu texto de 1911 à "Russian Geographic Society". Ele traduziu para o russo as palavras "medida" e "densidade" do grego, efetuando uma transliteração resultando - na Rússia - o termo "dazimetrichesky" e definindo o mapa dasimétrico como aquele em que a densidade de população, independentemente dos limites administrativos, é mostrada porque é distribuída na "realidade", isto é, por pontos naturais de concentração e de rarefação. Petrov (2008) ainda coloca que a popularização do termo é devida à publicação, em 1923, da obra "Dasymetric Map of European Rússia" [BENJAMIN SEMENOV-TIAN-SHANSKY, edit. Dazimetricheskaya Karta Evropeiskoi Rossii (Carte dasymétrique de la Russie d'Europe), 1:420.000. Inst. d'Ittudes "Le Sol et le Sous-Sol," Leningrad, 1923.] - figura 7. Segundo ainda Petrov (2008), de 1920 a 1930 os cartógrafos russos utilizaram este termo como sinônimo de mapas de densidade populacionais. Na década posterior o uso deste termo desaparece rapidamente devido ao cancelamento do projeto "Dasymetric Map of European Rússia" e da repressão a Benjamin Semenov-Tian-Shanski e sua escola, pelo regime stalinista em 1936.

O trabalho de Benjamin (Veniamin Petrovich) Semenov-Tian-Shansky foi resenhado por Sten de Geer (GEER, 1926) na revista "Geographical Review" em 1926 e, em 1928, o próprio Benjamin publica, na mesma revista, um artigo onde introduz o termo e faz uma breve discussão de seu mapa dasimétrico. (SEMENOVTIAN-SHANSKY, B, 1928).

Petrov (2008) argumenta ainda que normalmente é creditado ao geógrafo americano John Kirtland Wright (1891-1969) a introdução do termo e do método dasimétrico, mas seu artigo só aparece em 1936 na revista "Geographical Review". Wright indica que o termo é de origem russa, mas não menciona Benjamin Semenov-Tian-Shansky.

\footnotetext{
${ }^{9}$ KAMENETSKY, V. Dazimetricheskiye karty. In Bol' shaia Sovetskai Entsiklopedia, vol. 20, ed. O. Yu. Shmidit. MoscoW: Dasymetric Maps. 176-78.
} 


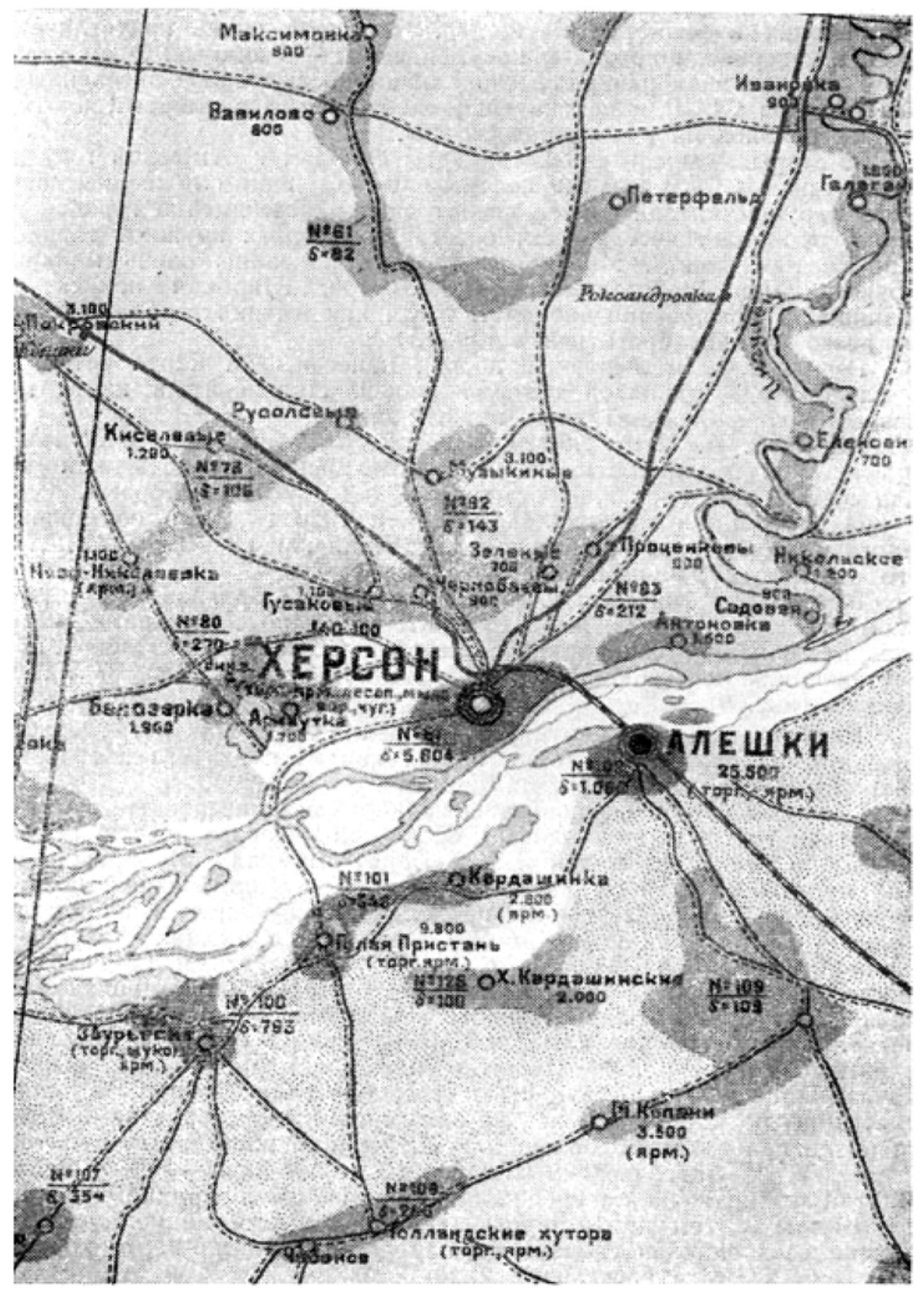

Figura 7 - Excerto de: "Dazimetricheskaya Karta Evropeiskoi Rossii (Carte dasymétrique de la Russie d'Europe), 1:420.000. Inst. d'Ittudes "Le Sol et le Sous-Sol," Leningrad, 1923.) Fonte: PREOBRAZHENSKY ${ }^{10}, 1954$, p.143. apud PETROV, 2008]

O geógrafo americano John Kirtland Wright, em 1936, apresentou mapas de densidades populacionais de áreas administrativas associadas a diferentes informações geográficas do meio natural de Cape Cod - estado de Massachusetts figuras 8 e 9 (WRIGHT, 1936).

\footnotetext{
${ }^{10}$ Preobrazhensky, A.J. "Dorevolutsionnye i Sovietskie Karty Razmescheniya Nasieleniya [Prerevolutionary and Soviet Maps of Population Density]." Voprosy Geografii: Kartografia 34: 134-49, 1954.
} 


\section{CAPE COD: POPULATION MAPS}

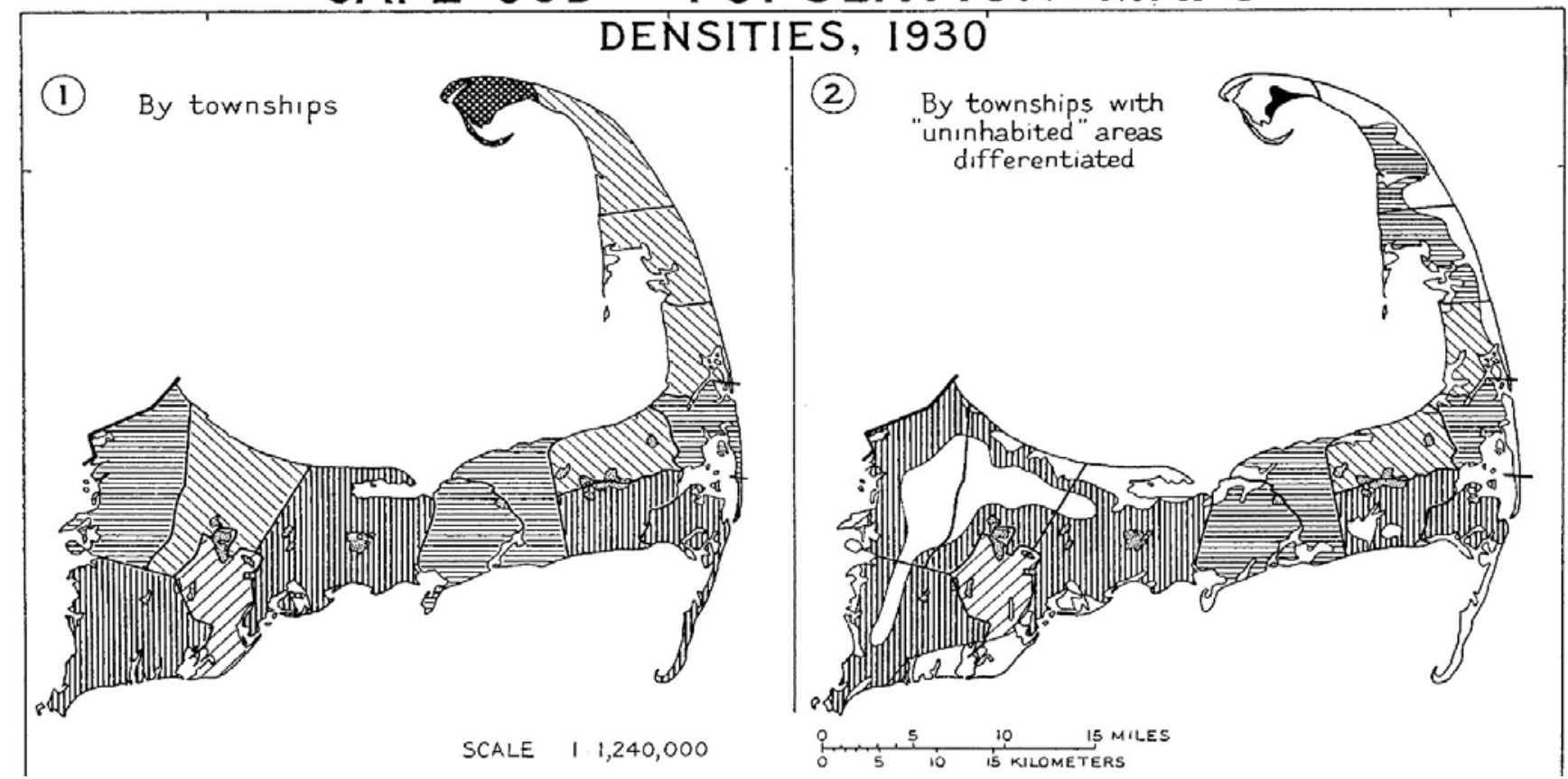

Figura 8

Mapa Coroplético Cape Cod

Diferenciação de áreas habitadas

(Estado de Massachusetts) e não habitadas

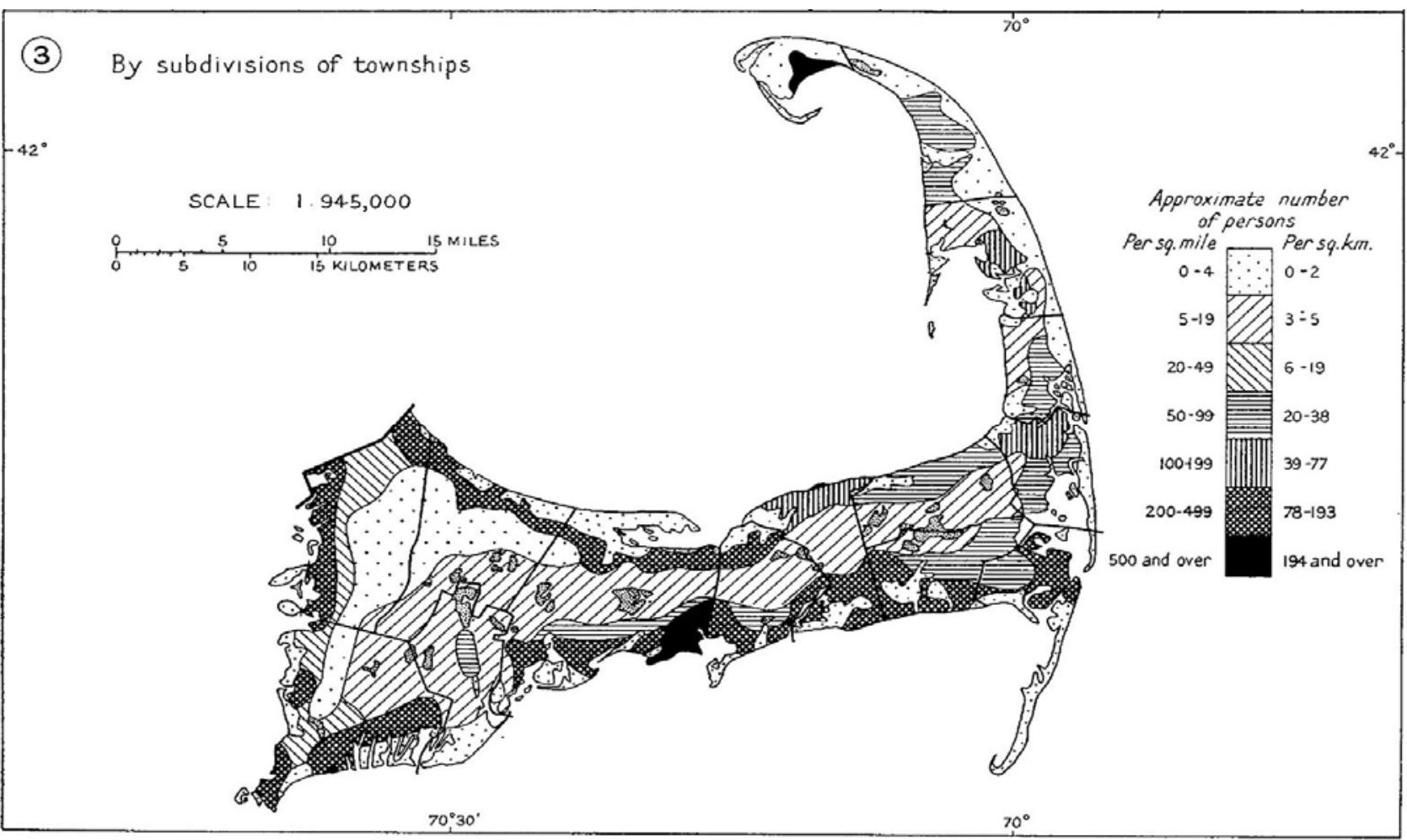

Figura 9 - Mapa Dasimétrico de Cape Cod (Estado de Massachusetts) 


\section{3 - A Técnica dasimétrica}

A técnica dasimétrica parte dos mesmos dados que são usados para realizar um mapa coroplético. Esses dados são divididos segundo outros fatores relacionados com a variável que se quer mapear. Os próprios dados não indicam em que zonas eles sofrem uma mudança brusca ou suave, necessitando, para tanto, buscar informações em outros dados que tenham relação estreita com a distribuição representada ou em outras variáveis geográficas.

Os fenômenos associados nesta técnica são de dois tipos: as chamadas variáveis limitativas e as variáveis relacionadas. As limitativas estabelecem um limite absoluto sobre a quantidade do fenômeno a ser cartografado e as relacionadas são aqueles fenômenos geográficos que mostram variações espaciais possíveis sobre a variável que se queira mapear, mas não são consideradas limitativas.

Para obter um mapa dasimétrico, primeiramente são delimitadas as áreas em que é seguro assegurar que a variável é nula - chamado de fatores de localização negativa, em seguida, delimita-se o restante das áreas em função de outras variáveis.

Como exemplo, suponhamos que se queira mapear por meio da técnica dasimétrica a porcentagem de terra agrícola em uma determinada região; primeiramente representam-se os dados por um mapa coroplético em que a porcentagem do corograma é conhecida, digamos que a superfície desta área representa $30 \%$ de terras agrícolas - fig. 10a. Em seguida estudamos outras distribuições na mesma área, por exemplo, a presença de áreas urbanas - variável limitativa - sendo de $10 \%$ - fig.10b. Desta maneira os $30 \%$ inicialmente admitidos à área agrícola aumentam na zona não urbana. Nesta área de estudo eliminamos a área urbana e associamos a um valor zero (localização negativa). Portanto, a densidade de terra agrícola para o resto da área aumenta para $33,33 \%$.

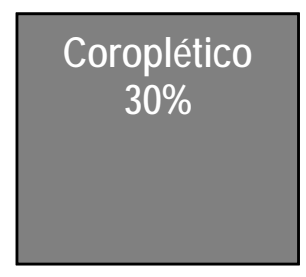

Figura 10a

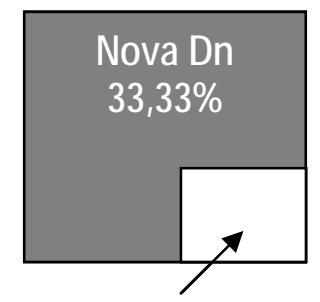

Área urbana (10\%)

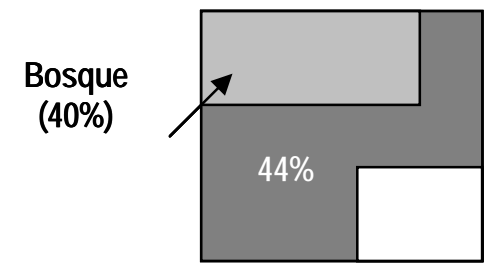

Figura 10c

Figura 10 - Exemplo de cálculo de densidade para mapas dasimétricos 
$\mathrm{Dn}=30 / 0,9=>\mathrm{Dn}=33,33 \%$

onde 0,9 veio de:

$30 \%$ corresponde ao $100 \%$ de toda a área;

De $10 \%$ da área urbana $=>$ sobrou $90 \%$ para a área agrícola $=>$ na porcentagem da nova superfície $(\mathrm{Sn})=0,9$

onde:

$$
\mathrm{Dn}=\mathrm{D} / \mathrm{Sn}(1)
$$

Dn é a nova densidade;

$\mathrm{D}$ a densidade conhecida;

Sn a porcentagem da nova superfície (de 0,1 a 0,9).

Podemos ainda dispor de outras informações, como exemplo, admitindo que haja uma área de bosque em torno de $40 \%$ da região (fig.10c). Teremos então uma nova densidade de terras agrícolas em torno de $44 \%$.

De um modo geral, teremos como cálculo da nova densidade de terras agrícolas:

$$
\mathrm{Dn}=\mathrm{D} /(\mathbf{1}-\mathrm{Sm})-\mathrm{DmSm}(1-\mathrm{Sm})(2)
$$

Sendo Dm a densidade estimada da nova variável limitante;

Sm a fração da superfície da nova variável limitante (de 0,1 a 0,9)

Dm e Sm são estimativas aproximadas, onde não é necessário medir Sm exatamente, já que o erro cometido será menor que a estimativa de Dm.

Desta forma podemos calcular ou estimar as novas densidades e observar que serão mais altas que em um mapa coroplético. Podemos ainda dispor também de outras informações dos tipos de variáveis relacionadas, como por exemplo, a morfologia do terreno ou as características do solo e estabelecer relações com a área ocupada com atividades agrícolas.
A técnica dasimétrica proporciona uma cartografia mais detalhada que a técnica coroplética e organiza as magnitudes trabalhadas dentro de uma visão mais geográfica, implicando em um conhecimento mais profundo do que se queira representar em mapas temáticos. Tradicionalmente essa técnica está ligada às representações de densidades de população e, apesar das vantagens que ela oferece, não tem sido muito utilizada para outros temas. (POVEDA, M e AGUIRRE,T. 1994, p71-73 - tradução nossa, grifos nossos).

Como o grau de dificuldade em elaborar mapas temáticos utilizando esta técnica é maior que com a técnica coroplética, ela foi pouco utilizada em trabalhos cartográficos. Com o desenvolvimento de Sistemas de Informações Geográficas que possibilitam sobrepor camadas de vários temas (variáveis limitantes ou relacionais) associadas com o fenômeno que queremos cartografar, juntamente com novas 
técnicas geoestatísticas, bases cartográficas auxiliares - fruto de sensoriamento remoto - a técnica dasimétrica é uma ferramenta que permite maior detalhamento do fenômeno a ser cartografado, é menos limitante a contornos preestabelecidos e, como resultado final, proporciona um mapa que apresenta informações de localizações e distribuições de densidades mais relevantes que o coroplético.

\section{4 - Aplicação da técnica dasimétrica: densidade Urbana da Metrópole de São Paulo}

Segundo ACIOLY e DAVIDSON (1998) a densidade urbana é o indicador e o parâmetro mais utilizado em processos de planejamento e gestão urbana. Ela representa uma dimensão relativa, expressando o número total da população de uma área urbana específica por unidade de terra ou solo urbano, ou o total de habitações de uma determinada área por unidade de terra. Utiliza-se o hectare [símbolo - ha - ] $\left(1\right.$ ha $\left.=10.000 \mathrm{~m}^{2}\right)$ como unidade de referência quando se trabalha com áreas urbanas. Utilizaremos o valor habitante por hectare (hab/ha) em nosso exemplo de aplicação da técnica dasimétrica.

A densidade urbana é um instrumento de apoio aos planejadores urbanos na hora de formalizar e decidir sobre a forma e extensão de áreas urbanas, bem como um indicador para avaliar a eficiência e o desempenho das propostas e/ou projetos de parcelamento do solo. A densidade urbana tornou-se um referencial para avaliar técnica e financeiramente a distribuição e consumo de terra urbana, infra-estrutura e serviços públicos em áreas residenciais. Qualquer que seja o modelo de nossas cidades: compactas, densamente ocupadas e verticalizadas ou cidades lineares, menos ou mais densas, todas significam qualidades distintas na qualidade, na intensidade, na singularidade do convívio urbano.

Escolhemos como exemplo de aplicação da técnica dasimétrica o espaço da metrópole paulista, composta por 39 municípios. Utilizaremos os dados censitários do IBGE e como variável auxiliar da técnica dasimétrica o "Mapa de Uso e Ocupação do Solo da RMSP" - EMPLASA - 2005.

A Região Metropolitana de São Paulo, criada pela Lei complementar número 14, de 08 de junho de 1973, é constituída pelo município de São Paulo e mais 38 municípios que se agrupam em torno da Capital do Estado e são diretamente por ela polarizados.

Os critérios que orientaram sua divisão regional foram, principalmente, a utilidade para racionalização da Administração 
Pública Estadual; os limites físicos das Regiões, a polarização urbana e as áreas de influência; além de critérios especiais ligados às atividades de planejamento e execução governamentais.

O Estado de São Paulo é composto atualmente por 15 Regiões Administrativas, incluindo a Região Metropolitana de São Paulo e as Regiões Metropolitanas de Campinas e da Baixada Santista, criadas após a promulgação da Constituição Federal de 1988, que autorizava os estados federados a instituírem regiões metropolitanas, aglomerações urbanas e microrregiões constituídas por conjuntos de municípios limítrofes. As unidades territoriais polarizadas (Regiões Administrativas) envolvem vários municípios interdependentes social e economicamente e associados a um pólo urbano principal.

Os 39 Municípios que integram a Região Metropolitana de São Paulo ocupam a área de $8.051 \mathrm{~km} 2$ e concentravam em 2000 cerca de $48 \%$ da população de todo o Estado, reunindo um total de 17.878.703 habitantes.(BÓGUS e PASTERNAK, 2009, P. 7-8)

\section{5 - Os setores censitários}

Em 4.4 afirmamos que a densidade urbana seria expressa pelo número total da população de uma área urbana específica por unidade de terra ou solo urbano. Os dados que utilizaremos para tal expressão são a "população residente formada pelos moradores em domicílios, na data de referência" (INSTITUTO BRASILEIRO DE GEOGRAFIA E ESTATÍSTICA - IBGE, 2003 p.251) - no caso o censo de 2000 computados nos setores censitários utilizados pelo Instituto Brasileiro de Geografia e Estatística (IBGE), como expressão espacial, que delimitam os setores administrativos dos municípios que compõem a Região Metropolitana de São Paulo.

A palavra censo vem do latim census e quer dizer "conjunto dos dados estatísticos dos habitantes de uma cidade, província, estado, nação". O Censo Demográfico, que acontece no Brasil de dez em dez anos, realizado pelo IBGE, tem por objetivo contar os habitantes do território nacional, identificar suas características e revelar como vivem os brasileiros (IBGE, 2003 p.9).

A promulgação da Constituição Federal de 1988 redefiniu o papel da União, dos Estados e dos Municípios, levando estes dois últimos a assumirem responsabilidades quanto aos planos de ordenamento e gestão do território. Inseriu-se neste contexto uma crescente demanda por informações em recortes territoriais mais desagregados, a fim de que as estatísticas atendam às exigências do planejamento local. Assim, a unidade mínima de coleta - setor censitário - passou a ser demandada não apenas para cumprir seu papel original de suporte à coleta, mas também como unidade de construção de áreas para o planejamento de ações, tanto do setor público quanto do privado (IBGE, 2003, p.273).

O setor censitário de 2000 teve por princípio básico a manutenção das áreas dos setores censitários de 1996, desde que esta situação 
não provocasse problemas na coleta, permitindo-se nesses casos a subdivisão ou agregação de setores de 1996, inteiros ou em parte, com base nos critérios estabelecidos e indicados a seguir:

- Setor de Área Urbana, Urbanizada - mínimo de 250 e máximo de 350 domicílios, de forma a propiciar a coleta do Censo Demográfico em até 30 dias;

- Setor de Área Urbana, Não-Urbanizada - mínimo de 150 e máximo de 250 domicílios ou, mínimo de 100 e máximo de 200 estabelecimentos agropecuários, com até 45 dias para coleta do Censo Demográfico;

- Setor de Área Rural - mínimo de 150 e máximo de 250 domicílios ou, mínimo de 100 e máximo de 200 estabelecimentos agropecuários ou área máxima de $500 \mathrm{~km} 2$; para coleta do Censo Demográfico em até 45 dias e, em até 60 dias, para coleta do Censo Agropecuário;

- Setor Aglomerado Rural - mínimo de 51 e máximo de 200 domicílios;

- Setor de Especial Aglomerado Subnormal (favelas e similares) mínimo de 51 e máximo de 350 domicílios;

- Setor Especial de Aldeia Indígena - mínimo de 20 habitantes indígenas em uma ou mais moradias;

- Setor Especial de Quartéis, Bases Militares etc. - mínimo de 50 moradores;

- Setor Especial de Alojamentos, Acampamentos etc. - mínimo de 50 moradores;

- Setor Especial de Penitenciárias, Colônias Penais, Presídios, Cadeias etc.- mínimo de 50 moradores; e

- Setor Especial de Asilos, Orfanatos, Conventos, Hospitais etc. mínimo de 50 moradores (IBGE, 2003, p.279).

\section{6 - "Mapa de Uso e Ocupação do Solo da RMSP" - EMPLASA}

Para o presente trabalho foram utilizados como dados auxiliares aqueles do "Mapa de Uso e Ocupação do Solo da Região Metropolitana de São Paulo" da Empresa Paulista de Planejamento Metropolitano - EMPLASA. Adotamos neste trabalho, nos títulos dos mapas e algumas partes do texto, a expressão espaço geográfico produzido na metrópole de São Paulo, mais de acordo com postura de que o espaço geográfico é produzido e não usado e ocupado ${ }^{11}$.

Segundo a EMPLASA as informações do "uso e ocupação do Solo" da RMSP foram obtidas através de interpretação de imagens do satélite Ikonos e fotografias aéreas na escala de 1:15.000. Para os municípios fora da RMSP, foram

\footnotetext{
${ }^{11}$ Quando estiver entre aspas refere-se ao nome do produto da EMPLASA.
} 
utilizadas fotografias aéreas disponíveis em diferentes escalas (Empresa Paulista de Planejamento Metropolitano - EMPLASA - 2005).

Para a região metropolitana - onde se encontra nosso recorte espacial foram utilizadas:

- Imagem Ikonos (Copyright Space Imaging), 2002/2003;

- Recobrimento Aerofotogramétrico na escala 1:15.000 - Multispectral Sistemas e Serviços Ltda, 2001/2003;

- Os limites municipais foram vetorizados a partir das cartas na escala de 1:10 000 do SCM, com os limites municipais autenticados pelo Instituto Geográfico e Cartográfico - IGC (EMPLASA, 2005, p7).

Para o mapeamento temático do Uso e Ocupação do Solo foi considerada, como menor unidade de referência a ser representada cartograficamente, na área de 4X4 mm na escala 1:25.000 (1 hectare) para os seguintes tipos de ocupação: Área Urbanizada, Mata, Capoeira, Campo, Vegetação de Várzea, Reflorestamento, Hortifrutigranjeiro, Movimento de Terra, Loteamento Desocupado e Chácaras. Os temas foram mapeados nas dimensões constantes das aerofotos e imagens de satélite (EMPLASA, 2005, p.10).

A interpretação das imagens Ikonos para a confecção do mapeamento temático de Uso e Ocupação do Solo foi fundamentada no mapeamento de Uso e Ocupação do Solo-Emplasa 1986, onde se pode estabelecer critérios e conceitos que subsidiaram a interpretação para a atual legenda. Além destes critérios, características como textura, cor, homogeneidade de elementos, formas regulares e irregulares de objetos foram analisadas para a definição de limites dos polígonos temáticos.

Para a delimitação dos diferentes usos foram utilizados os seguintes conceitos:

Mata - "Vegetação constituída por árvores de porte superior a 5 metros, cujas copas se toquem (no tipo mais denso) ou que propiciem uma cobertura de pelo menos $40 \%$ (nos tipos mais abertos)" (UNESCO, 1973). No caso de formações secundárias, não completamente evoluídas, o porte das árvores pode ser inferior a 5 metros, tendo, porém, esses elementos apenas um tronco (são árvores e não arbustos).

Capoeira - "Vegetação secundária que sucede à derrubada das florestas, constituída principalmente por indivíduos lenhosos de segundo crescimento, na maioria, da floresta anterior e por espécies espontâneas que invadem as áreas devastadas, apresentando porte desde arbustivo até arbóreo, porém com árvores finas e compactamente dispostas" (SERRA F. ${ }^{\circ}$ et al, 1975). 
Campo - Vegetação caracterizada, principalmente, pela presença de gramíneas, cuja altura, geralmente, varia de 10 a $15 \mathrm{~cm}$ aproximadamente, constituindo uma cobertura que pode ser quase contínua ou apresentar-se sob a forma de tufos deixando, nesse caso, alguns trechos de solo a descoberto. Espaçadamente poderão ocorrer pequenos subarbustos e, raramente, arbustos. (ROMARIZ, 1974).

Vegetação de várzea - "Vegetação de composição variável que sofre influência dos rios, estando sujeita inundações periódicas, na época das chuvas (UNESCO, 1973). As vegetações arbóreas de Mata e Capoeira, localizadas nas áreas de várzea, foram classificadas como Mata e Capoeira".

Reflorestamento - Formações arbóreas e homogêneas, cultivadas pelo homem com fim econômico (há predominância de eucalipto e pinus na RMSP).

Hortifrutigranjeiro - Áreas de cultura perene ou anual, horticultura, granja e psicultura definidas abaixo:

Culturas - Áreas ocupadas por espécies frutíferas (árvores ou arbustos) e culturas como: arroz, trigo, milho, forragens, cana-deaçúcar etc.

Horticultura - "Áreas de cultivo intensivo de hortaliças e flores, plantadas continuamente nos mesmos terrenos" (KELLER, 1969).

Granja - Engloba todas as instalações para criação de frangos e produção de ovos.

Piscicultura/Pesqueiro - Engloba todas as instalações visíveis para criação de peixes.

Movimento de Terra - Áreas que sofreram terraplanagem, apresentando solo exposto pela remoção da cobertura vegetal.

Solo Exposto - Solo preparado para cultivo e áreas que se encontram sem cobertura vegetal, devido à ação de processos erosivos.

Mineração - Áreas de extração mineral e seu entorno (movimento de terra, cavas, edificações) que sofreram efeito desta atividade. $\mathrm{Na}$ RMSP é realizada a céu aberto para praticamente todos os minérios e seu desenvolvimento. Caracteriza-se pela remoção da cobertura vegetal e corte de relevo. Foram incluídas no mapeamento das áreas de mineração desativadas que ainda apresentam característica de mineração.

Área urbanizada - Constituída por áreas arruadas e efetivamente ocupadas por uso residencial, comercial e de serviços, além disso, é caracterizada por ruas e edificações. Foram mapeadas como área urbanizada as quadras e partes de quadras vagas e condomínios de prédios em construção, garagem de ônibus, supermercados, postos de gasolina, shopping centers, etc.

Chácara - Foram mapeados como chácaras os loteamentos de chácaras de lazer ou de uso residencial e as sedes de sítios que se encontram, sobretudo, ao longo das estradas vicinais. Formam um conjunto de propriedades menores, com certa regularidade no terreno e são identificadas pela presença de pomares, hortas, solo preparado para plantio, lagoas, bosques, quadras de esportes, 
piscinas etc. As áreas de horta e pomar foram englobadas nesta categoria quando apresentavam características de subsistência.

Loteamento desocupado - Áreas arruadas com até $10 \%$ de ocupação, podendo estar localizadas dentro da área urbanizada, na periferia ou isoladas. É caracterizado necessariamente por um conjunto de arruamentos, podendo ser geométrico ou irregular, sobre solo com ou sem cobertura vegetal.

Favela - Conjunto de unidades habitacionais (barracos, casas de madeira ou alvenaria) dispostas, em geral, de forma desordenada e densa. O sistema viário é constituído por vias de circulação estreita e de alinhamento irregular. As favelas que sofreram processo de urbanização foram incluídas no uso urbano.

Indústria - Área caracterizada pela presença de grandes edificações, pátios de estacionamento, localizados dentro ou fora de área urbanizada. Foram mapeadas como indústria as olarias, que são pequenas áreas destinadas à produção de tijolos, telhas etc.

Equipamento urbano - Área ocupada por estabelecimentos, espaços ou instalações destinadas à educação, saúde, lazer, cultura, assistência social, culto religioso ou administração pública, que tenham ligação direta, funcional ou espacial com uso residencial. A Vegetação foi identificada pelo tipo, não sendo quantificada como área no Equipamento Urbano.

Aterro sanitário - Área de "disposição final de resíduos sólidos urbanos no solo, através de confinamento em camadas cobertas com material inerte, geralmente solo, segundo normas específicas, de modo a evitar danos ou riscos à saúde e à segurança, minimizando os impactos ambientais" (ABNT, 1989).

Lixão - Áreas de depósitos de resíduos sólidos a céu aberto, sem nenhum tratamento.

Reservatório de retenção - Reservatório de controle de cheias com saídas não reguláveis (ANEEL \& OMM, 1999).

Rodovia - Áreas ocupadas por rodovias com largura acima de 25 metros.

Outro uso - Áreas que não se enquadram nos padrões definidos, tais como: comércio e serviço ao longo das estradas ou isolados (Ex: Rancho da Pamonha, Posto de Gasolina, Churrascaria, Revenda de Automóveis, Motel, Hotel, Haras, Laboratório da Dersa, Estação Experimental, Cooperativa Agrícola de Cotia, etc). Foram também incluídos os Movimentos de Terra, com construções em andamento sem identificação de uso, localizado dentro ou fora da área urbanizada.

Na execução do projeto foi acrescido "Reservatório de Retenção" na legenda proposta pelo Termo de Referência, e foram eliminadas da legenda "Áreas de Proteção Legal" e "Áreas Verdes Urbanas". As informações referentes às "Áreas de Proteção Legal" foram levantadas pela Emplasa, mas a fonte da escala da informação não era compatível com a representação na escala de 1:25 000. As "Áreas Verdes Urbanas" passíveis de representação foram mapeadas no item "Vegetação" e as demais, incluídas na "Área Urbanizada". (EMPLASA, 2005. p.10-13) 


\section{7 - Procedimentos Metodológicos}

\subsection{1 - Objetivos:}

Produção de mapas de densidade urbana na escala de 1:400.000 ${ }^{12}$.

1. Coroplético $\rightarrow>$ representando a densidade populacional dos setores censitários - IBGE 2000;

2. Dasimétrico -> representando a densidade populacional dos setores censitários - IBGE 2000 "cruzados" com o "uso e ocupação do solo" - variáveis limitantes e relacionadas.

\subsection{2 - Abrangência espacial:}

- Metrópole de São Paulo [RMSP]

\subsection{3 - Bases cartográficas e dados estatísticos utilizados:}

- Setores Censitários: Base digital em formato vetorial - shape file com dados do censo do IBGE de 2000. Projeção: Universal Transversa de Mercator - Datum: SAD69 - fuso $23 S$.

- Uso e ocupação do solo: Mapa de Uso e Ocupação do Solo da RMSP - EMPLASA - 2005 - 1:25.000 - Projeção: Universal Transversa de Mercator - Datum: SAD69 - fuso 23S. Formato original dos arquivos: shape - compatível com o programa ARCGIS;

- Base cartográfica: Base digital em formato vetorial - shape file dos municípios da Região Metropolitana de São Paulo - IBGE 2000 - Projeção: Universal Transversa de Mercator - Datum: SAD69 fuso 235 .

\subsection{4 - Programa utilizado:}

- ARCGIS 9.1 - da ENVIRONMENTAL SYSTEMS RESEARCH INSTITUTE (ESRI) => espacialização/cálculos estatísticos/layout final do mapa coroplético e dasimétrico.

\footnotetext{
${ }^{12}$ Mapa nesta escala encontra-se em anexo no formato A3.
} 
4.7.5 - Fluxo de trabalho:

1. FORMATO DE DADOS 1:

1.1 - BASE CARTOGRÁFICA - RMSP - IBGE

- SHAPE(ARCGIS)

1.2 - SETORES CENSITÁRIOS - RMSP

- $\operatorname{SHAPE}(A R C G I S)$

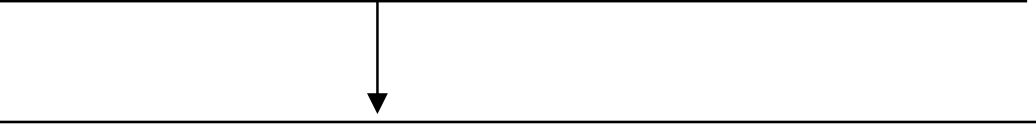

2. FORMATO DE DADOS 2:

- "Mapa de Uso e Ocupação do Solo da RMSP" EMPLASA - 2005.

SHAPE $(A R C G I S)$ => mapa 1 pg. 67

3. CONFECÇÃO DO MAPA

COROPLÉTICO (ARCGIS):

DENSIDADE URBANA USANDO SETORES

\section{CENSITÁRIOS}

3.1 - Criação do campo área em hectare;

3.2-Conversão da área dos polígonos dos

setores censitários de $\mathrm{m}^{2}$ para hectare (ha)

$\left(\mathrm{m}^{2} / 10.000\right)$;

3.3 - Criação do campo densidade no banco de dados do setor censitário;

3.4 - Cálculo da densidade de cada setor censitário.

3.5- Confecção do mapa. => mapa4, pg. 70 


\section{CONFECÇÃO DO MAPA DASIMÉTRICO (ARCGIS):}

4.1 Seleção dos tipos de ocupação no mapa de uso e ocupação que indicam a maior probabilidade da população residente formada pelos moradores em domicílios (variáveis relacionadas): área urbanizada e favela (ferramenta "clip" do ARCGIS). Os demais usos foram considerados como variáveis limitativas e asseguramos que a variável é nula (0 zero) - chamados de fatores de localização negativa - onde não é ocupado por população residente; => mapa 2 , pg. 68

4.2 Cruzamento (ferramenta "overlay intersect" do ARCGIS) dos polígonos dos setores censitários dos distritos com os polígonos de ocupação selecionados no item 4.1; => mapa 3, pg. 69

4.3 Conversão do cruzamento do item 4.2 em arquivo de formato linha (polyline);

4.4 Conversão do item 4.3 em formato polígono;

4.5 Cruzamento do arquivo do item 4.4 com os setores censitários;

4.6 Novo cruzamento com a seleção de polígonos do item 4.1;

4.7 Criação de novos campos no arquivo resultante do item 4.6:

4.7.1.1 Área em hectare (para conversão de $\mathrm{m}^{2} \mathrm{em} \mathrm{ha);}$

4.7.1.2 Áreas do cruzamento - São as novas áreas que efetivamente se encontram população residente;

4.7.1.3 Áreas do cruzamento em hectare (para conversão de $\mathrm{m}^{2} \mathrm{em}$ ha);

4.7.1.4 Proporção das novas áreas em relação a área total do setor censitário;

4.7.1.5 Nova densidade (para cálculo conforme eq. (1) da p. 51).

4.8 Cálculos dos itens de 4.7;

4.9 Confecção do mapa dasimétrico. =>mapa 5, pg. 72

\section{Obervação:}

Os itens 4.3, 4.4, 4.5 e 4.6 foram necessários porque os polígonos associados às áreas urbanas+favela - itens selecionados - estão associados ao banco de dados do arquivo "shape" do ARCGIS e estes não desagregam espacialmente quando executamos o primeiro cruzamento. Ao transformamos em linhas (polyline) 
desassociamos o banco de dados com seu respectivo campo: área urbanizada e favela e criamos espacialmente as áreas realmente intersectadas pelos polígonos do setor censitário. É necessário, então, transformá-los em polígonos, associarmos novamente os dados dos setores censitários e finalmente cruzá-los com as áreas urbanizadas e favelas.

\subsection{6 - Fluxo sintético do mapa dasimétrico}

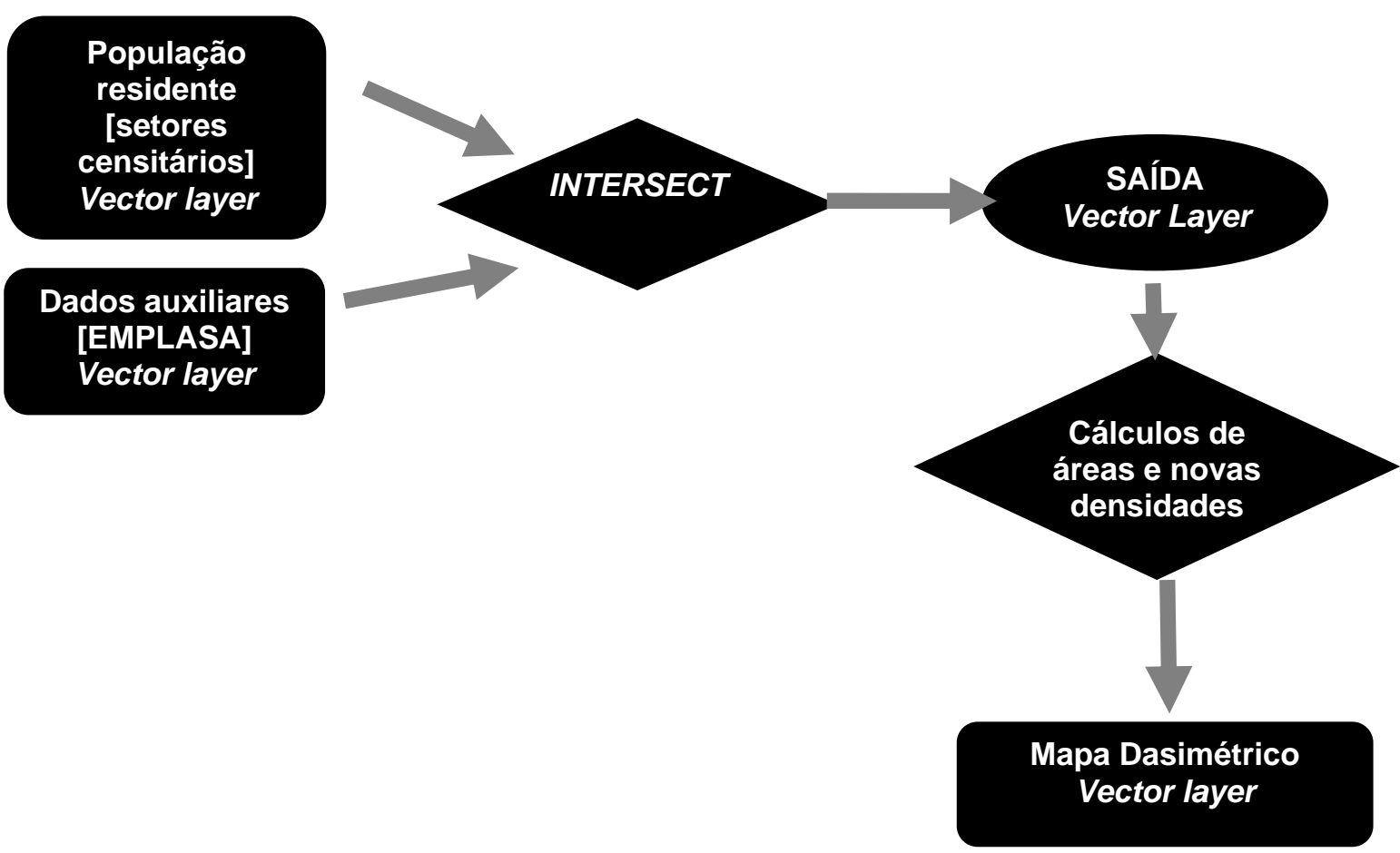

Figura 11 - Fluxo de elaboração de um mapa dasimétrico 


\section{8 - Resultados e análises}

Produzimos 5 mapas que demonstram as fases de elaboração do mapa dasimétrico da metrópole paulista, conforme detalhado tecnicamente no item $4.7 .5 \mathrm{e}$ 4.7.6:

Mapa 1 => Espaço geográfico produzido na metrópole de São Paulo. [instantâneo de uma produção empreendida pela sociedade até os anos 2.000]. Fruto das classificações realizadas e segundo os métodos da EMPLASA [ver páginas 55 a 57] que culminou no produto: "Mapa de uso e ocupação do solo da Região Metropolitana de São Paulo" finalizado em 2005;

Mapa 2 => Espaço urbano da metrópole de São Paulo. Representação do espaço - segundo classificação da EMPLASA como “Área urbanizada - Constituída por áreas arruadas e efetivamente ocupadas por uso residencial, comercial e de serviços" - e que adotamos aqui como a área com maior probabilidade de existência de população residente. Objetos geográficos fundamentais para serem relacionados com os setores censitários;

Mapa 3 => Espaço urbano, censitário e "virtual" da metrópole de São

Paulo. Fruto de uma intersecção matemática/geométrica de três [3] representações:

espaço urbano - já visualizado pelo mapa 2;

espaço censitário - unidades básicas operacionais utilizadas pelo IBGE para realizar os censo demográfico de 2.000;

espaço da "intersecção" matemático/geométrica em ambiente virtual [aplicativo SIG] do espaço urbano e censitário. São as áreas onde efetivamente se encontra população residente É este espaço que será representado pelo mapa dasimétrico;

Mapa 4 => Mapa coroplético da metrópole de São Paulo. Mapa utilizando o espaço censitário do IBGE para representar a densidade de população residente;

Mapa 5 => Mapa dasimétrico da metrópole de São Paulo. Representação fruto dos três mapas anteriores que contribuem para formar uma imagem do urbano - no caso a cidade de São Paulo. 


\section{Resgatando os três eixos apresentados no Capítulo 3 como}

subsídios/métodos para avaliar e analisar as representações do espaço geográfico no caso o espaço urbano de São Paulo - temos:

\begin{tabular}{|c|c|c|c|}
\hline EIXO/MÉTODO & $\begin{array}{l}\text { MAPA } 1 \\
\text { Espaço geográfico produzido } \\
\text { na metrópole de São Paulo }\end{array}$ & $\begin{array}{l}\text { MAPA } 2 \\
\text { Espaço urbano } \\
\text { da metrópole de São Paulo }\end{array}$ & $\begin{array}{l}\text { MAPA } 3 \\
\text { Espaço urbano, censitário e } \\
\text { "virtual" da metrópole e São Paulo }\end{array}$ \\
\hline 1/1 - Espaço de referência & metrópole de São Paulo & metrópole de São Paulo & metrópole de São Paulo \\
\hline 1/2 - Escala(s) cartográficas? & $\begin{array}{l}\text { sim - "válido" apenas para o } \\
\text { fundo de mapa }\end{array}$ & $\begin{array}{l}\text { sim - "válido" apenas para o } \\
\text { fundo de mapa }\end{array}$ & $\begin{array}{l}\text { sim - "válido" apenas para o fundo de } \\
\text { mapa }\end{array}$ \\
\hline $\begin{array}{l}\text { 1/3 - Princípio que norteou a } \\
\text { transposição analógica do } \\
\text { espaço referente para o espaço } \\
\text { no mapa. }\end{array}$ & $\begin{array}{l}\text { Limites observados: } \\
\text { espaço produzido pelo seu uso: } \\
\text { urbano, favela, industrial, } \\
\text { sistema viário, vegetação, } \\
\text { reservatório de água, etc }\end{array}$ & $\begin{array}{l}\text { Limites observados: } \\
\text { espaço produzido pelo seu } \\
\text { uso: urbano }\end{array}$ & $\begin{array}{l}\text { Limites observados: espaço } \\
\text { produzido pelo seu uso: urbano } \\
\text { Limite operacional: unidades } \\
\text { censitárias segundo IBGE } \\
\text { Limite calculado: intersecção dos } \\
\text { dois espaços acima } \\
\end{array}$ \\
\hline 1/4 - Métrica(s) utilizada(s) & $\begin{array}{l}\text { Euclidiana, para fundo de mapa } \\
{[\mathrm{km}]}\end{array}$ & $\begin{array}{l}\text { Euclidiana, para fundo de } \\
\text { mapa }[\mathrm{km}]\end{array}$ & Euclidiana, para fundo de mapa $[\mathrm{km}]$ \\
\hline $\begin{array}{l}\text { 1/5 - "Temas", qual ou quais } \\
\text { substâncias contempladas? }\end{array}$ & $\begin{array}{l}\text { urbano, favela, indústria, vias, } \\
\text { vegetação, água, etc }\end{array}$ & urbano e favela & urbano e humanos \\
\hline $\begin{array}{l}\text { 1/6 - Semiologia de representação } \\
\text { gráfica empregada } \\
\text { [T4 - transformação semiótica] }\end{array}$ & $\begin{array}{l}\text { modo de implantação: zonal } \\
\text { nominal/qualitativa } \\
\text { corocromática }\end{array}$ & $\begin{array}{l}\text { modo de implantação: zonal } \\
\text { nominal/qualitativa } \\
\text { corocromática }\end{array}$ & $\begin{array}{l}\text { modo de implantação: zonal } \\
\text { nominal/qualitativa } \\
\text { corocromática }\end{array}$ \\
\hline 2 - Transformação cartográfica & $\begin{array}{l}\text { T3 - TRANSFORMAÇÃO DE } \\
\text { ESTADO } \\
\text { Aplicação de Z no espaço dos } \\
\text { localizantes XY }\end{array}$ & $\begin{array}{l}\text { T3 - TRANSFORMAÇÃO DE } \\
\text { ESTADO } \\
\text { Aplicação de Z no espaço } \\
\text { dos localizantes XY }\end{array}$ & $\begin{array}{l}\text { T3 - TRANSFORMAÇÃO DE } \\
\text { ESTADO } \\
\text { Aplicação de Z no espaço dos } \\
\text { localizantes XY }\end{array}$ \\
\hline 3 - Tipo de mapa & $\begin{array}{l}\text { "À leitura espacial", fundo de } \\
\text { mapa convencional, } \\
\text { mapa euclidiano }\end{array}$ & $\begin{array}{l}\text { "À leitura espacial", fundo de } \\
\text { mapa convencional, } \\
\text { mapa euclidiano }\end{array}$ & $\begin{array}{l}\text { "À leitura espacial", fundo de mapa } \\
\text { convencional, mapa euclidiano }\end{array}$ \\
\hline
\end{tabular}

\begin{tabular}{|l|l|l|}
\hline EIXO/MÉTODo & $\begin{array}{l}\text { MAPA 4 } \\
\text { Mapa coroplético da densidade } \\
\text { de população da metrópole de São Paulo }\end{array}$ & $\begin{array}{l}\text { MAPA 5 } \\
\text { Mapa dasimétrico da densidade } \\
\text { de população da metrópole de São Paulo }\end{array}$ \\
\hline 1/1 - Espaço de referência & metrópole de São Paulo & metrópole de São Paulo \\
\hline 1/2 - Escala(s) cartográficas? & sim - "válido" apenas para o fundo de mapa & sim - "válido" apenas para o fundo de mapa \\
\hline $\begin{array}{l}\text { 1/3 - Princípio que norteou a } \\
\text { transposição analógica do } \\
\text { espaço referente para o espaço } \\
\text { no mapa. }\end{array}$ & $\begin{array}{l}\text { Limites "abstratos": Resultado do cálculo de } \\
\text { número de habitantes por área censitária. }\end{array}$ & $\begin{array}{l}\text { Limites espaciais calculados pelo tratamento de } \\
\text { espacial calculadas em função/ em relação a } \\
\text { áreas de espaço produzido pelo urbano }\end{array}$ \\
\hline $\begin{array}{l}\text { 1/4 - Métrica(s) utilizada(s) } \\
\text { 1/5 - "Temas", qual ou quais } \\
\text { substâncias contempladas? }\end{array}$ & Euclidiana, para fundo de mapa [km] & Euclidiana, para fundo de mapa [km] \\
\hline $\begin{array}{l}\text { 1/6 - Semiologia de representação } \\
\text { gráfica empregada } \\
\text { [T4 - transformação semiótica] }\end{array}$ & $\begin{array}{l}\text { modo de implantação: zonal } \\
\text { quantitativo relativo ordenado } \\
\text { variável visual: cor/valor } \\
\text { coroplético }\end{array}$ & concentração de humanos \\
\hline 2 - Transformação cartográfica & $\begin{array}{l}\text { T3 - TRANSFORMAÇÃO DE ESTADO } \\
\text { Aplicação de Z no espaço dos localizantes XY }\end{array}$ & $\begin{array}{l}\text { modo de implantação: zonal } \\
\text { quantitativo relativo ordenado } \\
\text { variável visual: cor/valor } \\
\text { coroplético }\end{array}$ \\
\hline 3 - Tipo de maño de Z no espaço dos localizantes XY \\
\hline
\end{tabular}


Baseado no quadro 1, página anterior, qual a diferença de um mapa coroplético - mapa 4 - e o dasimétrico - mapa 5 ? O método revela que a única diferença foi o princípio que norteou a transposição analógica do espaço referente para o espaço no mapa. Os setores censitários, ou seja, as unidades espaciais do mapa coroplético foram estabelecidas por necessidades operacionais do IBGE. Para o mapa dasimétrico são novas unidades espaciais. Utilizamos as unidades espaciais operacionais do IBGE e que foram relacionadas com uma fração do espaço produzido pela sociedade humana - espaço urbano. Os novos limites espaciais terão então a sua população residente - a variável não espacial "Z" recalculada em função das novas áreas.

Esta transformação, este tratamento de "Z" forneceu o diferencial entre as duas imagens que os mapas revelam - a metrópole de São Paulo. O mapa dasimétrico melhor espacializou o fenômeno que estamos trabalhando. Como instrumento de comunicação ele apresentou e transmitiu informações de localizações e distribuições de densidades populacionais mais relevantes que o coroplético. O dasimétrico deu um "peso" maior para as periferias e realçou também os espaços não habitados da metrópole. Mesmo sendo os dois mapas - coroplético e dasimétrico - "mapas à leitura espacial" pelo critério 3 - tipo de mapa - o dasimétrico poderia ganhar alguns "pontos" extras.

Realizamos um "zoom" para uma escala cartográfica de mais detalhes - para o município de Osasco: o mapa 6, o coroplético e o mapa 7, o dasimétrico. Comparando-os fica evidente o realce de mais áreas com índices de densidade mais altos no dasimétrico.

Para estabelecer as classes de densidades deparamos com a reflexão de Jacobs:

Quais são as densidades apropriadas a áreas residências em cidades? A resposta para isso é algo como a resposta que Abraham Lincoln deu à questão. 'Qual deve ser o comprimento das pernas de um homem? Longas o suficiente para alcançarem o chão, disse Lincoln'. Assim é, densidades apropriadas a áreas residências em cidades são uma questão de performance. Elas não podem estar baseadas em abstrações sobre as quantidades de solo urbano que idealísticamente devem ser alocadas para tal ou tal número de pessoas (vivendo em alguma sociedade dócil e imaginária). Densidades são muito baixas, ou muito altas, quando frustram a diversidade da cidade ao invés de estimulá-la. Nós temos que olhar para densidades da mesma maneira como olhamos para calorias e vitaminas. Quantidades certas são quantidades certas por causa de 
como se comportam. E o que é correto difere em instâncias específicas (JACOBS, 2000, p.230-231, grifos nossos).

"Quais são as densidades apropriadas a áreas residenciais em cidades?" Quais classes de densidade populacional residente expressariam no mapa densidades ideais? Seriam representações de densidades baixas, médias ou altas, que intensificam ou frustram a diversidade urbana? São indagações que este trabalho não ousou responder. Densidade urbana ideal é difícil de ser quantificado, já que fatores culturais, econômicos, legais, estruturais, etc, influenciam em seu cálculo.

Optamos em adotar classes de densidade urbana que expressassem:

- um limiar de alerta - que segundo a ONU seria de - 450 hab/ha ou segundo a Associação Americana de Saúde Pública em torno de 680 hab/ha;

- acima de 1.500 hab/ha como uma densidade elevada (RODRIGUES, apud BORTOLUZZI e HOCHHEIM, 2004, p.6).

Observamos nos mapas realizados até agora, que a técnica dasimétrica aperfeiçoou, aprimorou o mapa coroplético da densidade urbana da metrópole paulista. O mapa coroplético mostra certa homogeneidade de densidade em áreas onde predominam índices menores que o limiar de 450 hab/ha. No dasimétrico, pelo contrário, realça áreas de densidades superiores ao 450hab/ha e aponta áreas com índices acima de 1500 hab/ha.

A técnica dasimétrica proporcionou uma cartografia mais detalhada, que a habilita a ser um instrumento mais refinado e preciso na análise da densidade urbana para planejadores urbanos e técnicos que avaliam e analisam a distribuição e utilização de áreas urbanas, infra-estrutura e serviços públicos necessários a áreas residenciais.

Permite ainda estabelecer relações outras como a distribuição espacial de equipamentos educacionais, culturais, de saúde, riscos ambientais, indicadores socioeconômicos, etc, em relação a estes espaços representados e realçados pela técnica dasimétrica. Mesmo não sendo objetivo principal deste trabalho, resolvemos dar dois exemplos destas relações. Com o material da EMPLASA elaboramos o mapa 8 , que mostra a relação do dasimétrico com os equipamentos urbanos e favela 
e o mapa 9, onde realçamos a favela no dasimétrico e comparamos com o coroplético.

Segundo a classificação da EMPLASA (2005, p.10-13) o equipamento urbano é uma "área ocupada por estabelecimentos, espaços ou instalações destinadas à educação, saúde, lazer, cultura, assistência social, culto religioso ou administração pública, que tenham ligação direta, funcional ou espacial com uso residencial". Por sua vez a favela é o "conjunto de unidades habitacionais (barracos, casas de madeira ou alvenaria) dispostas, em geral, de forma desordenada e densa".

Transformamos estas áreas - equipamento urbano e favela - que estavam no formato de polígonos em pontos no aplicativo ARCGIS e relacionamos com a camada das áreas densas da metrópole. Pela imagem formada, - mapa 8 - em grande parte da metrópole há uma correspondência de densidade de equipamentos com a densidade de população. No caso da favela, separamos entre duas classes de densidades; uma abaixo e outra acima do limiar indicado pela ONU - 450 hab/ha. É visível a correlação entre altas densidades populacionais e as localizações de favelas - realçadas no mapa 9 . Tendo a densidade de população destas áreas pode-se estimar o número de habitantes que seriam beneficiados pelo uso dos equipamentos urbanos existentes e a quantidade de pessoas residentes em favelas.

Para concluir, incluímos no mapa 10 a rede viária com o dasimétrico. Não foi tão significativo, mas útil para comprovar a baixa densidade viária em áreas mais densas de população - a periferia da metrópole. O sistema ferroviário, que representaria um sistema de transporte público mais adequado, possui uma malha ínfima em áreas de densidades mais elevadas. 


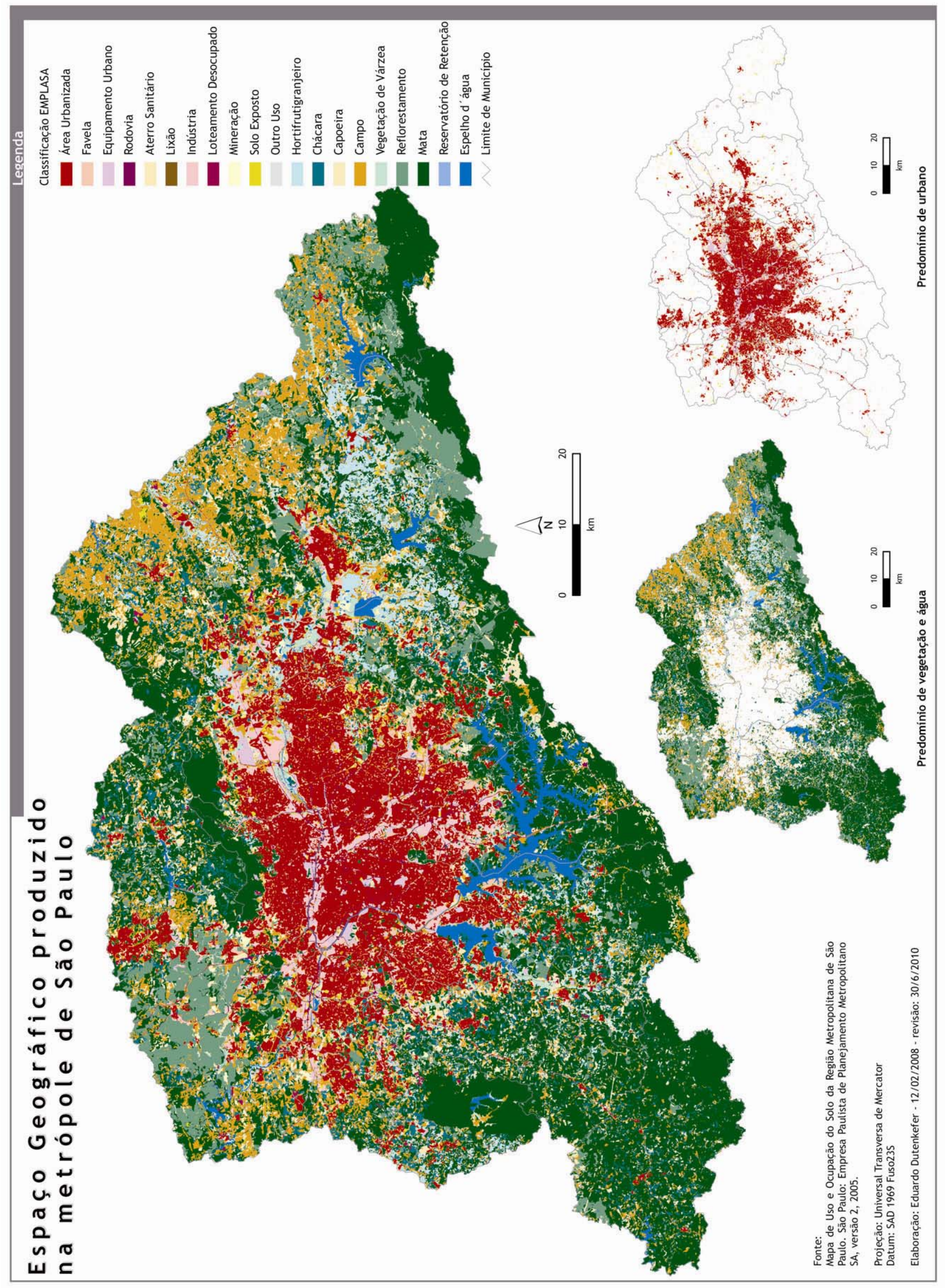

Mapa 1 - Espaço geográfico produzido na metrópole de São Paulo 


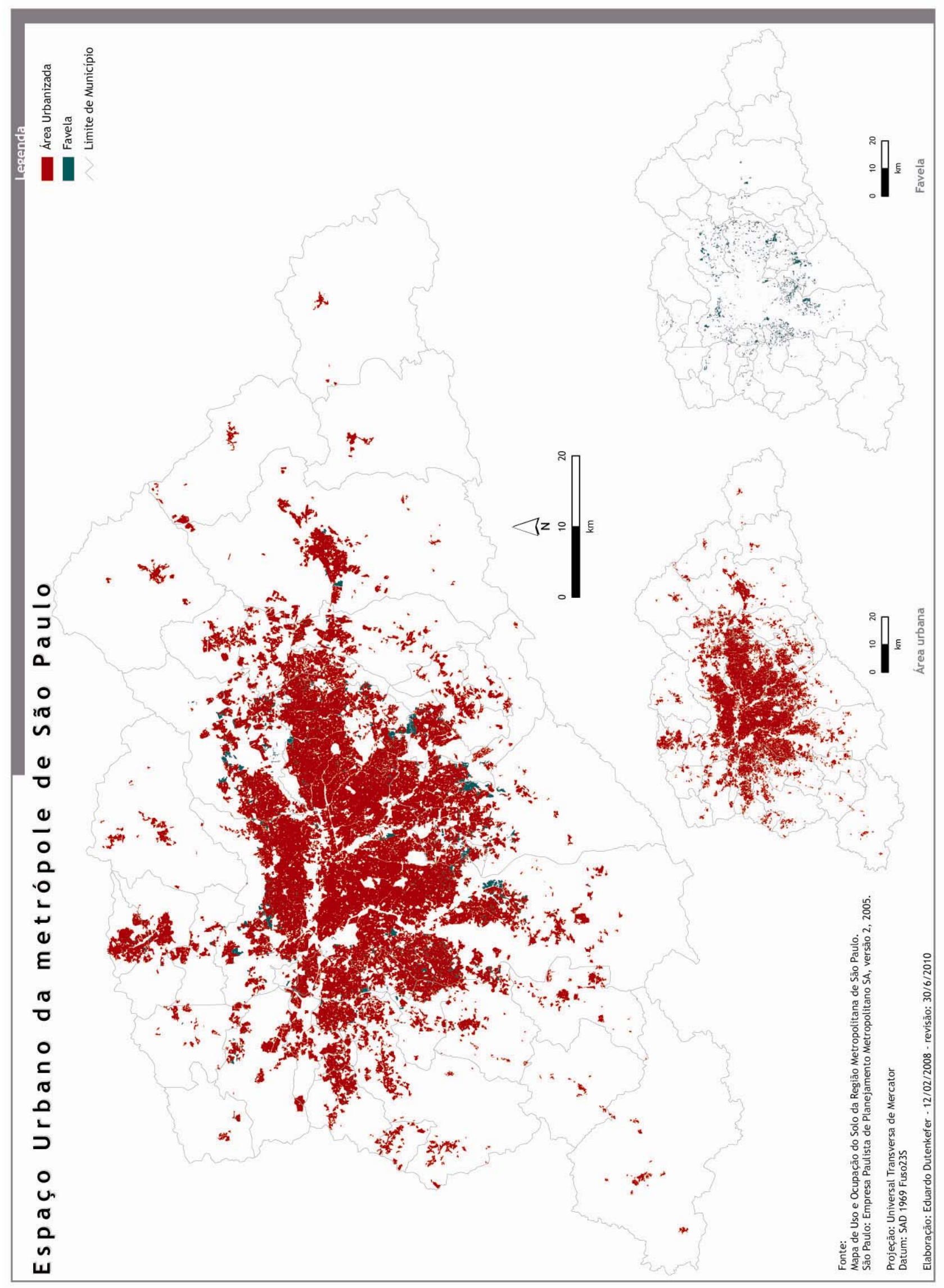

Mapa 2 - Espaço urbano da metrópole de São Paulo 


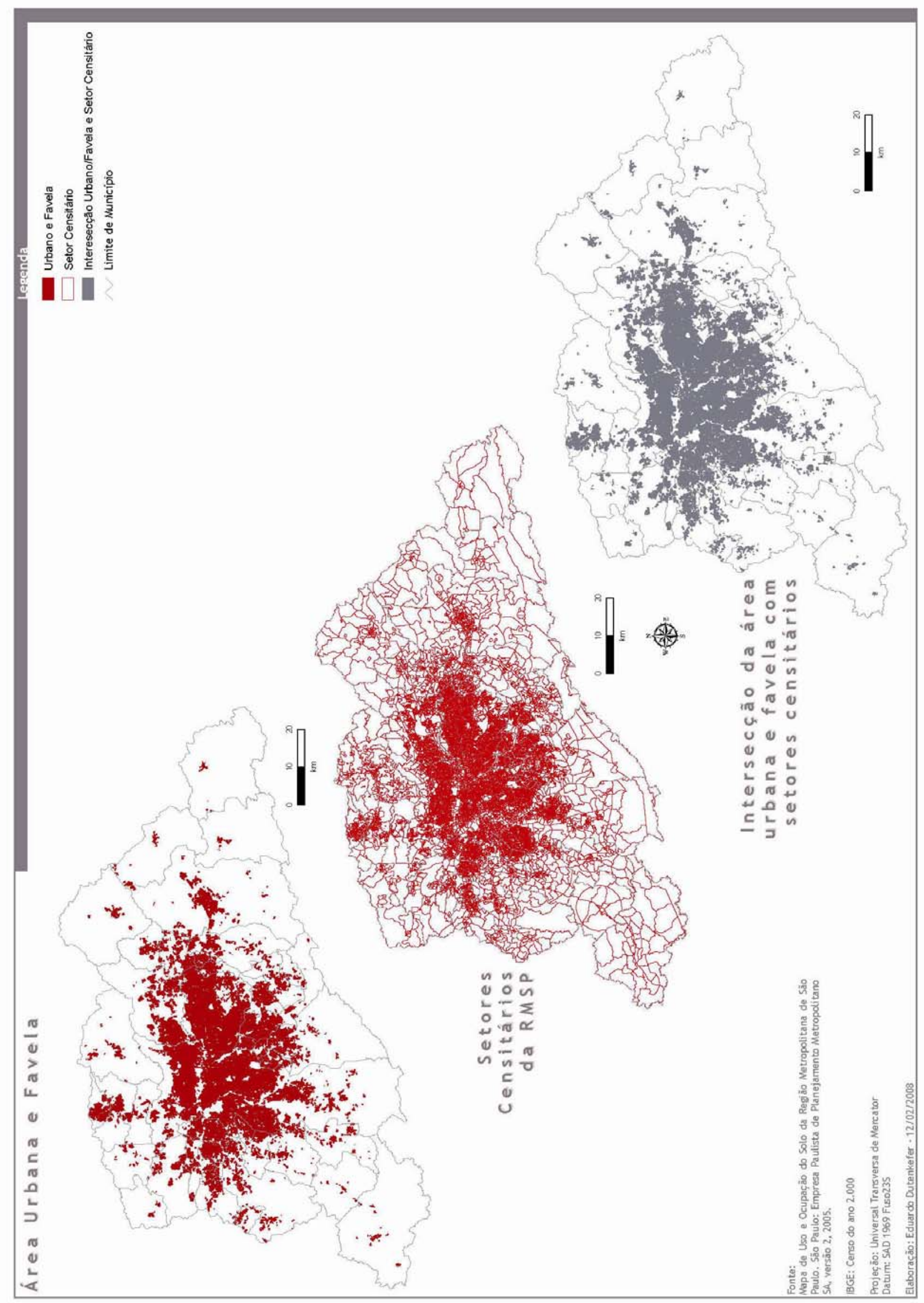

Mapa 3 - Espaço urbano, censitário e "virtual" da metrópole de São Paulo 


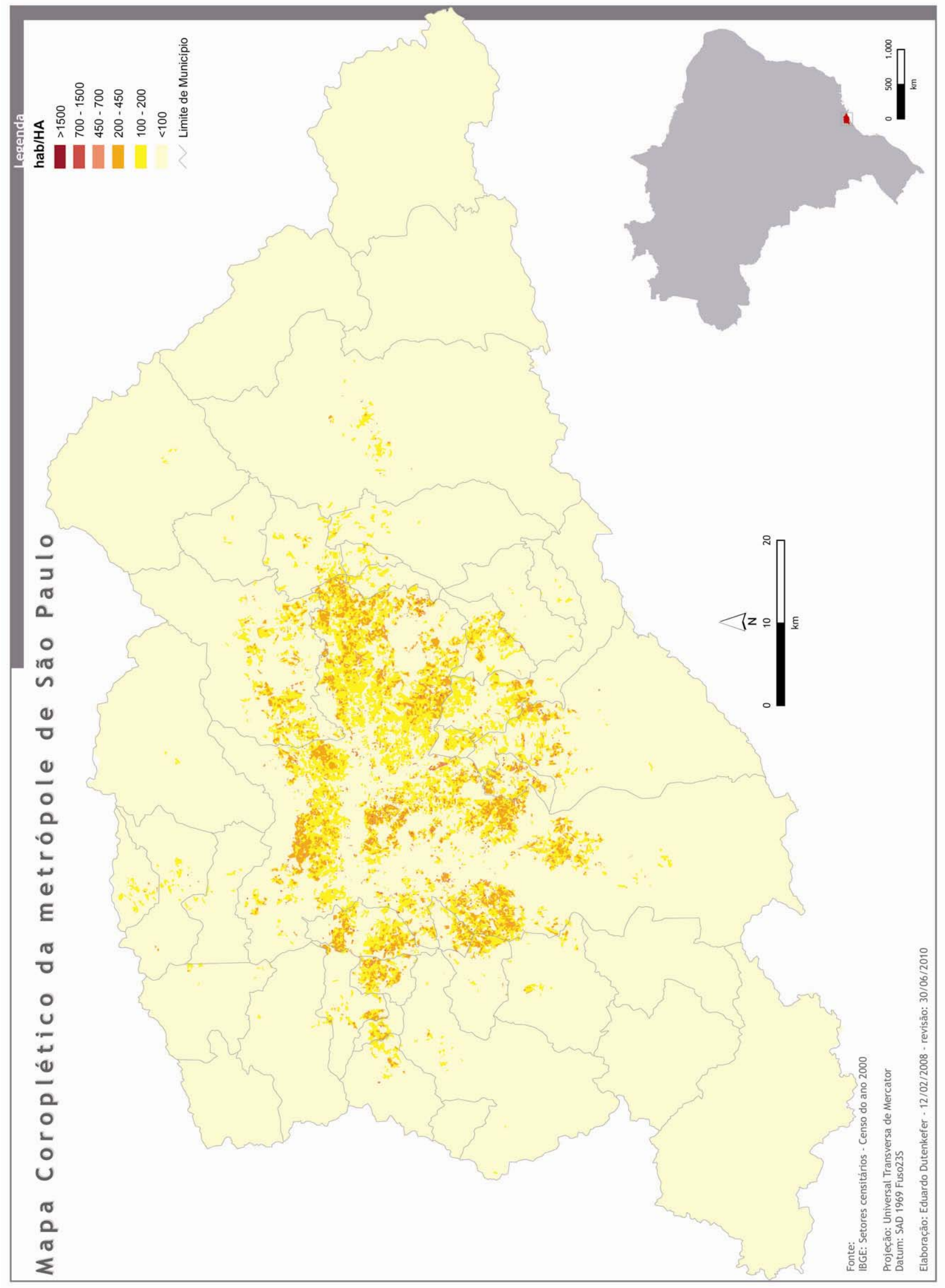

Mapa 4 - Mapa coroplético da metrópole de São Paulo 


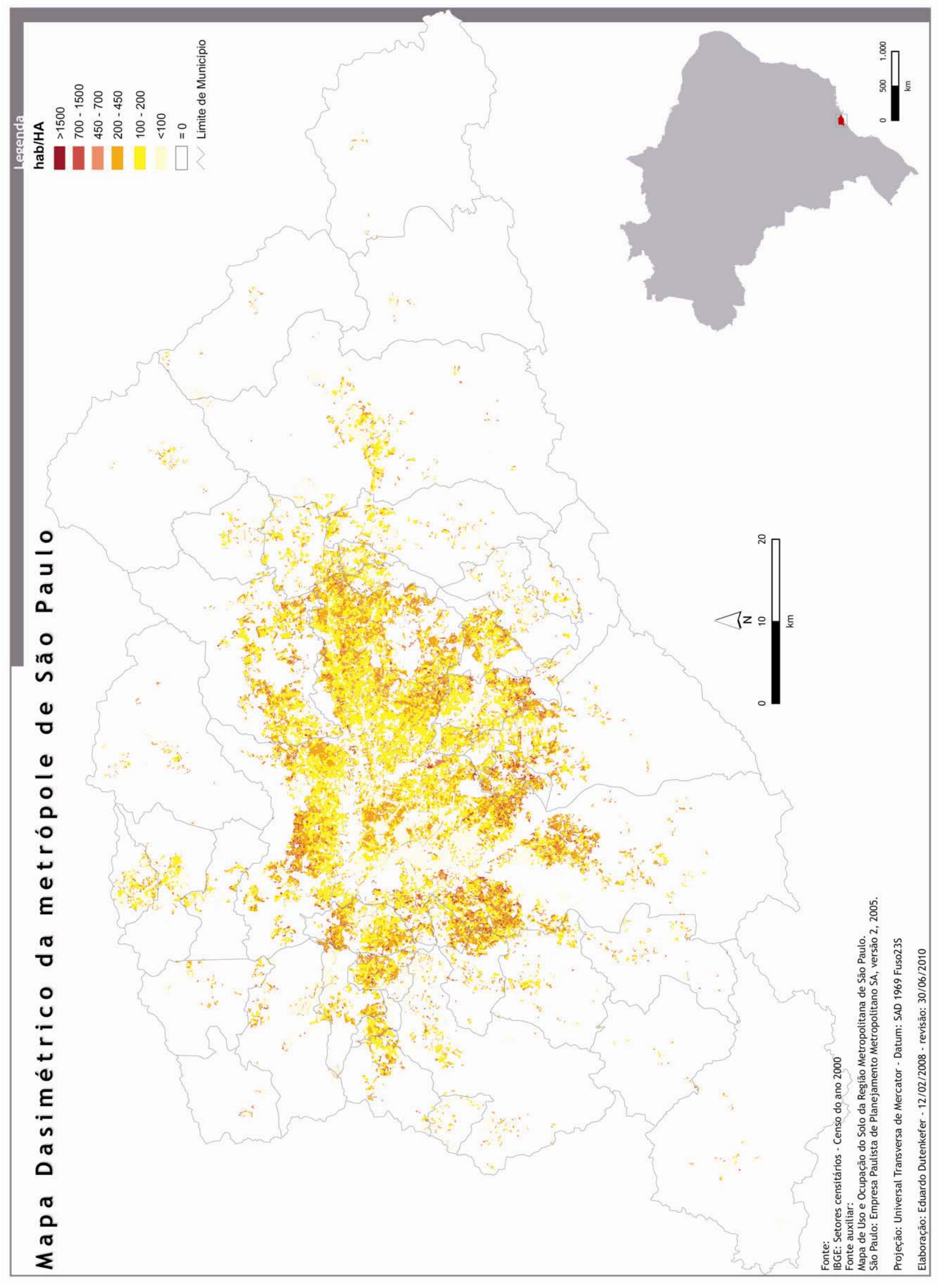

Mapa 5 - Mapa dasimétrico da metrópole de São Paulo 
Mapa Coroplético da Densidade Urbana do Municipio de Osasco

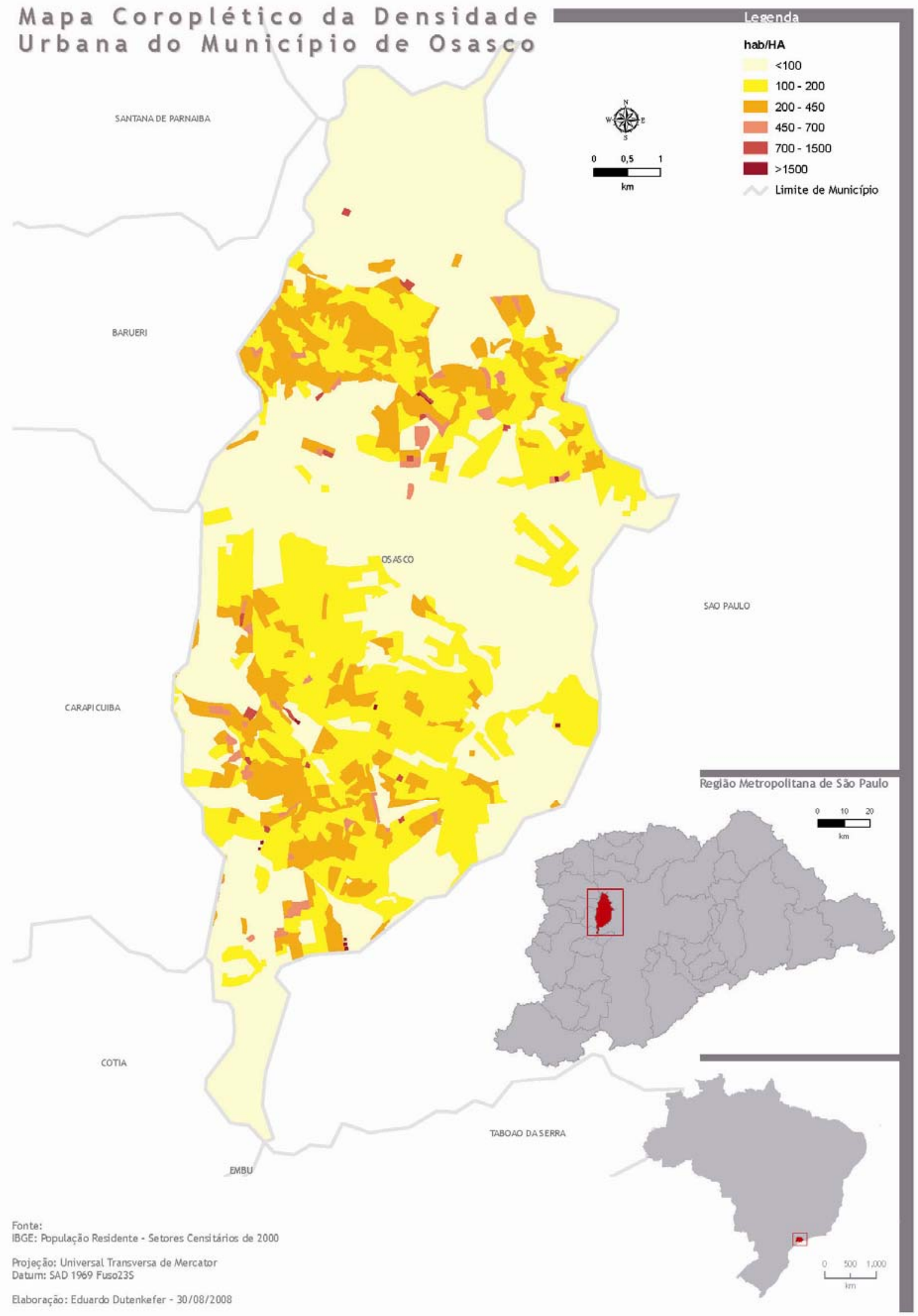

Mapa 6 - Mapa coroplético da densidade urbana do Município de Osasco 


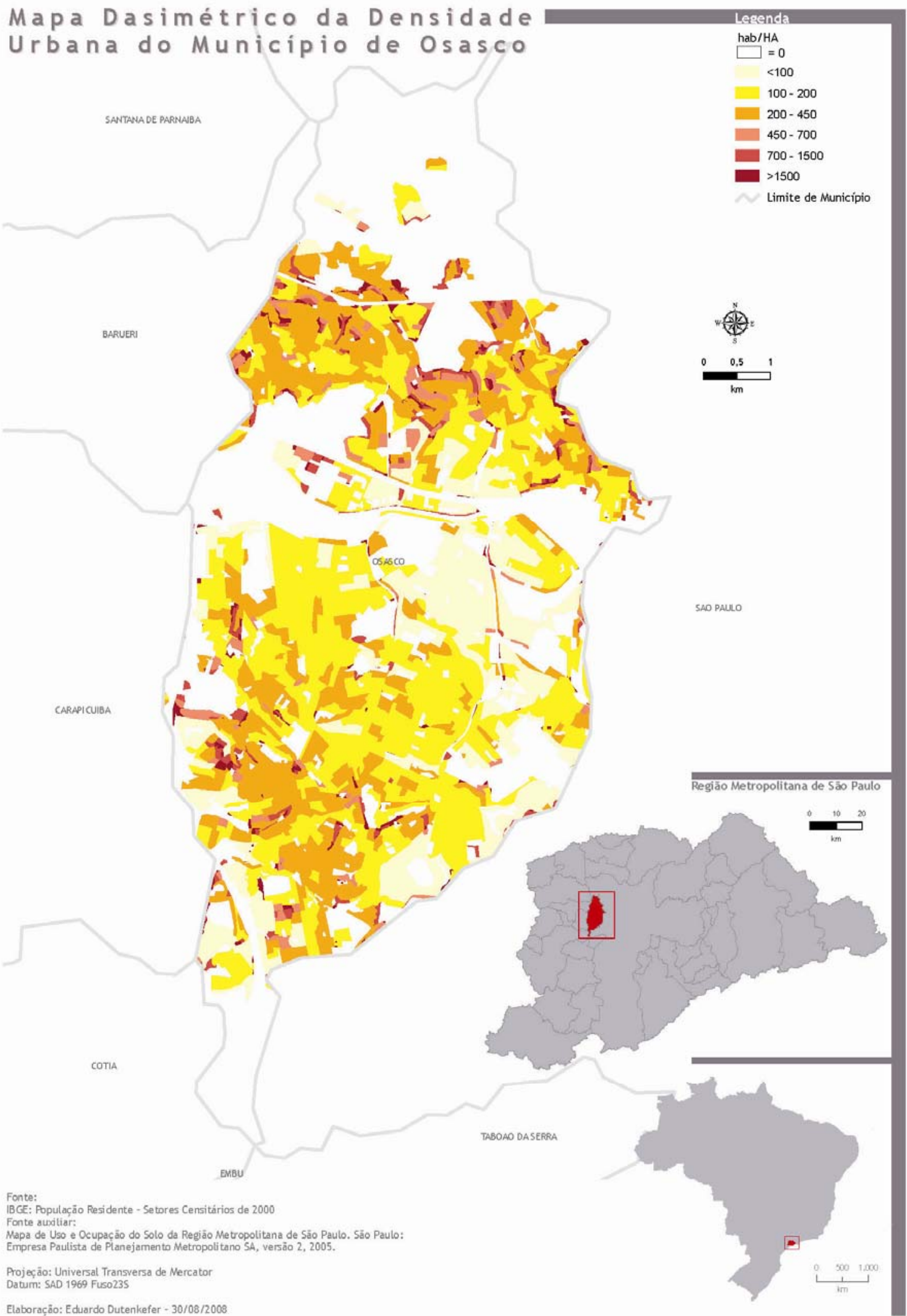

Elaboração: Eduardo Dutenkefer - 30/08/2000

Mapa 7 - Mapa dasimétrico da densidade urbana do Município de Osasco 


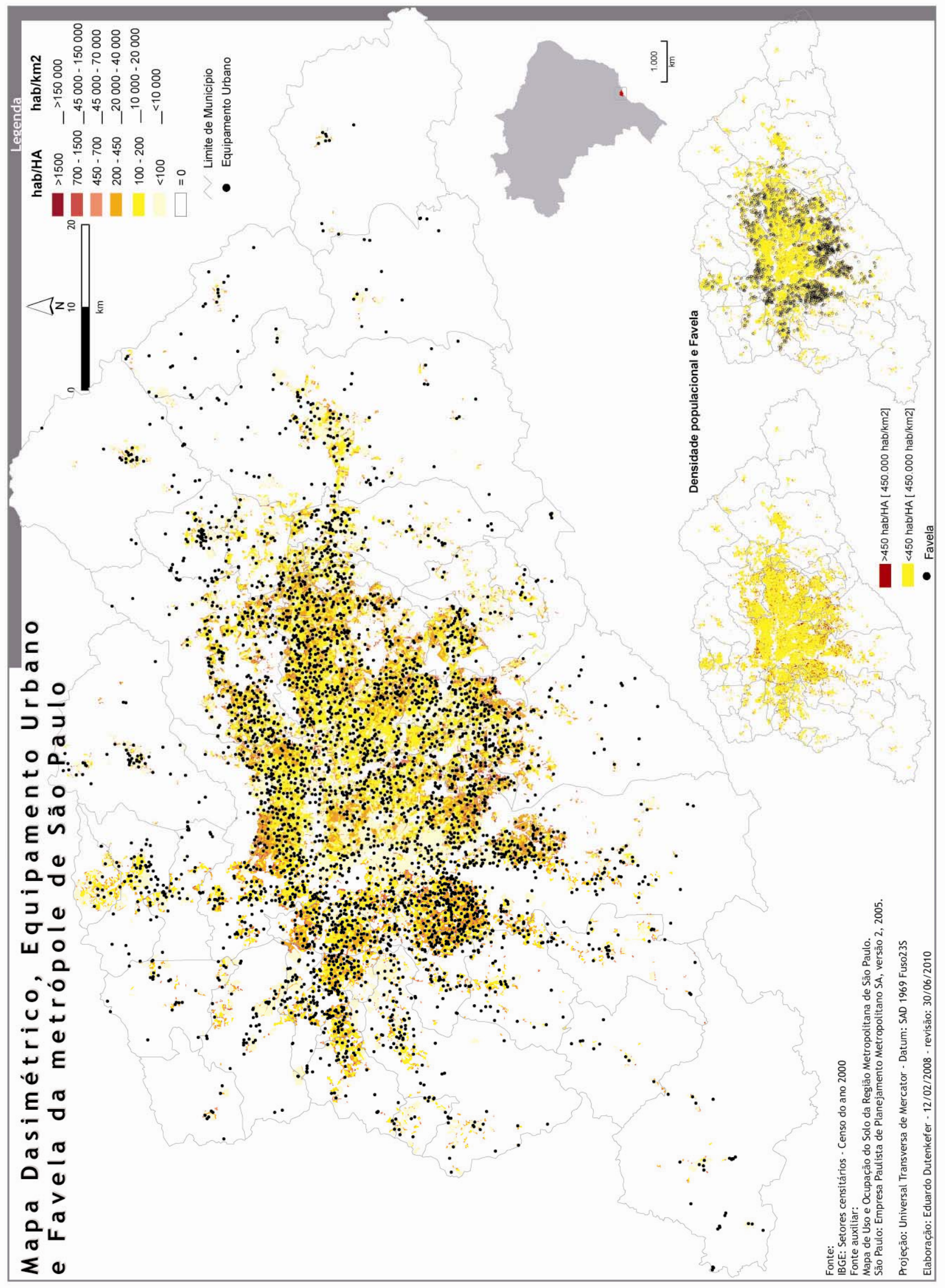

Mapa 8 - Mapa dasimétrico da metrópole de São Paulo relacionado com equipamento urbano e favela 


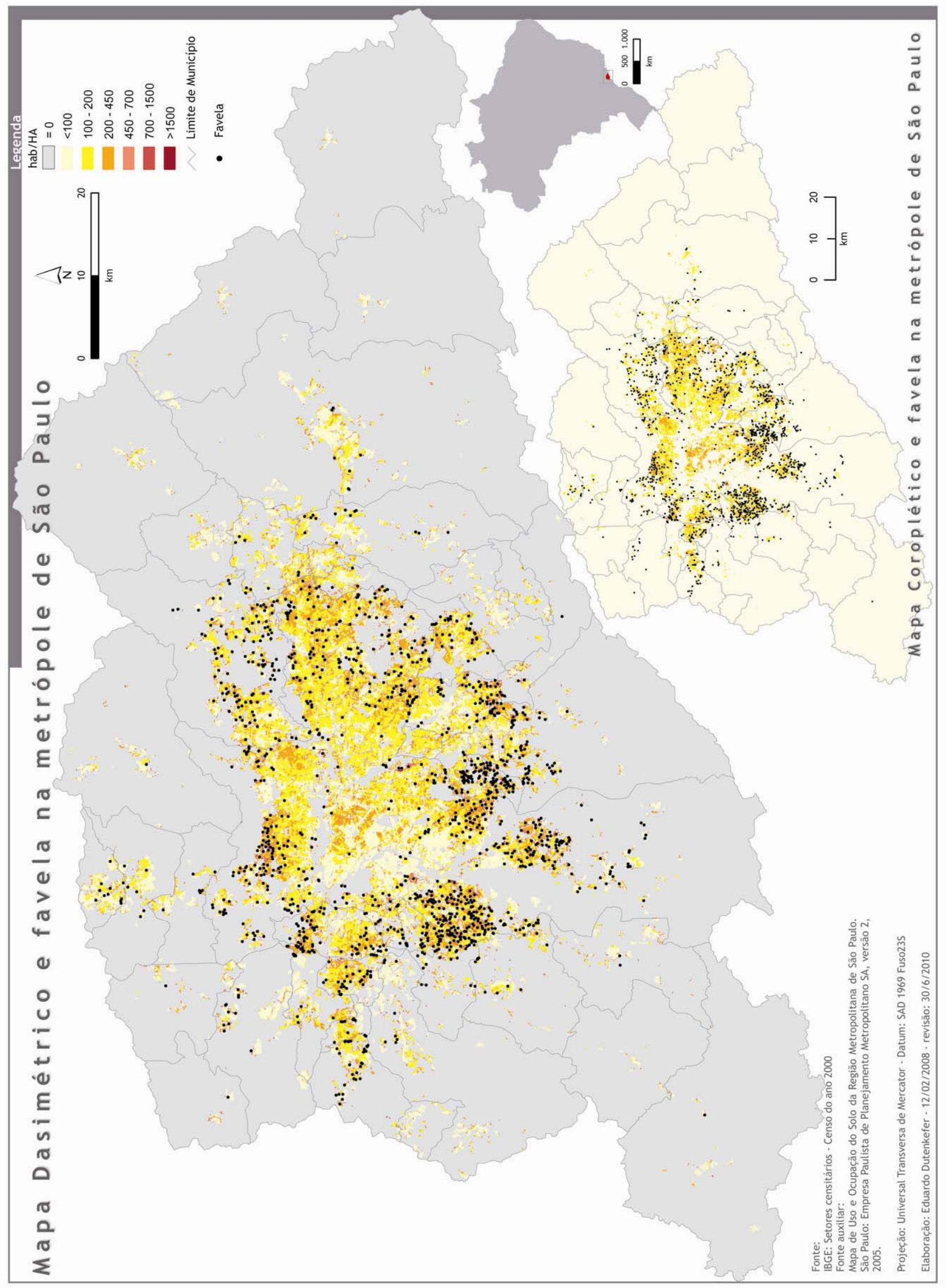

Mapa 9 - Mapa dasimétrico e coroplético da metrópole de São Paulo relacionado com favela 


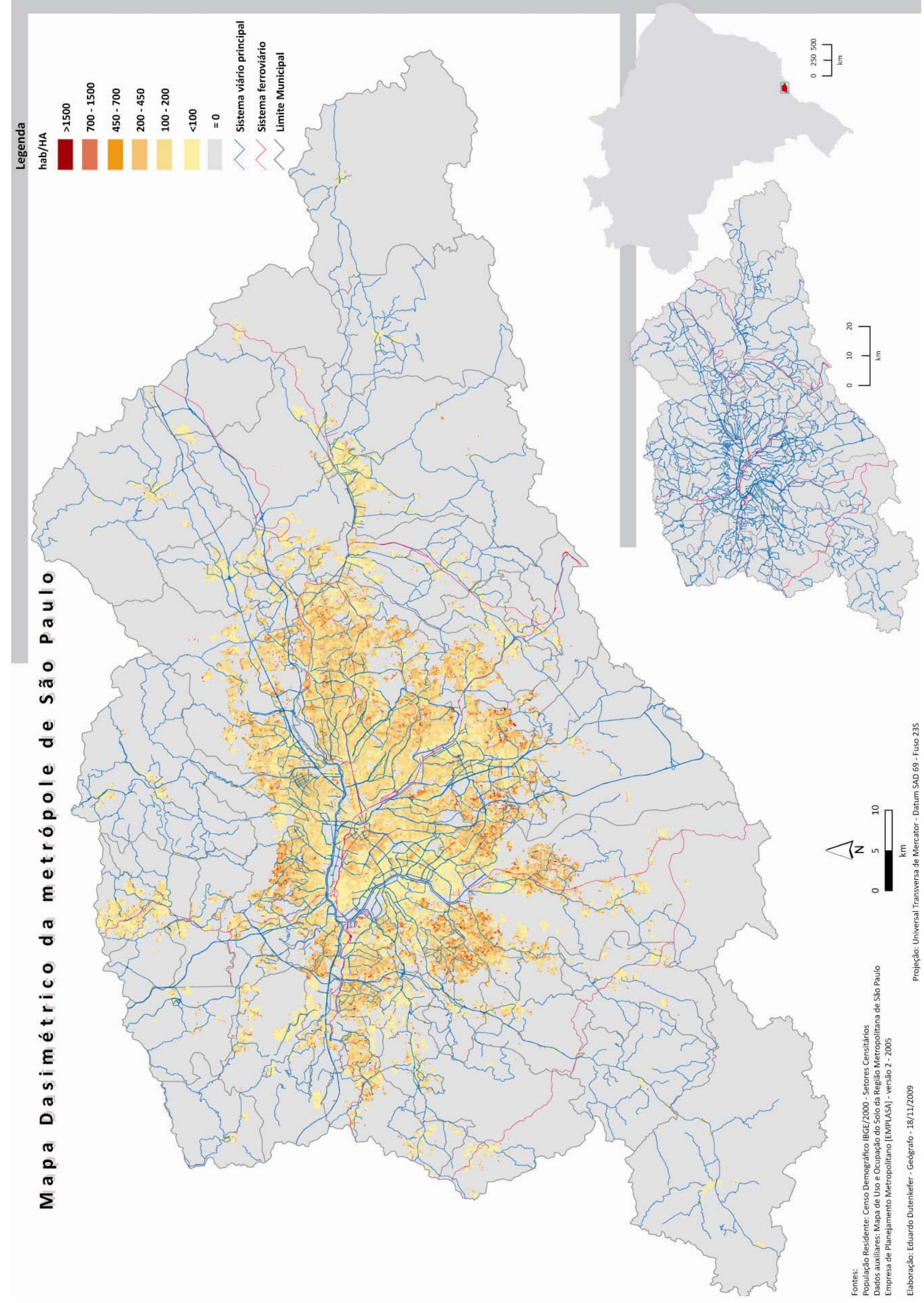

Mapa 10 - Mapa dasimétrico e rede viária e ferroviária 


\title{
5.0 - TRANSFORMAÇÕES CARTOGRÁFICAS ESPACIAS DE POSIÇÃO: ANAMORFOSES
}

\begin{abstract}
...após séculos de busca da fidelidade e do rigor na representação da Terra, o computador invade as atividades cartográficas e facilita a "deformação", das suas imagens convencionais e a criação de novas, ao sabor da nossa percepção do Mundo. Mas quando o geógrafo procede a estas alterações profundas na representação do globo, muitos dizem tratar-se de traição à verdade (DIAS, Maria Helena. 1991, p.52).

Tobler considera que é necessário ser sempre aberto as novidades e testá-las, porque permitem frequentemente renovar a disciplina e assim apreender a uma melhor compreensão dos fenômenos distribuídos sobre a superfície da Terra (CAUVIN et al, 2007, p.49, tradução nossa).
\end{abstract}

\section{1 - Introdução}

Os mapas em anamorfose chocam o nosso olhar adestrado, familiarizado a representações "naturalizadas", com o fundo de mapa convencional, euclidiano, onde as métricas são expressas em metros, quilômetros, hectares; onde a extensão do espaço geográfico representado limita a comunicação visual que todo mapa deveria proporcionar. Limita tendências espaciais relevantes, de fenômenos como o urbano, por exemplo, que sobre um fundo euclidiano nada evidenciam ou, quando evidenciam, é a extensão territorial pouco densa, rarefeita de objetos geográficos que dão sentido ao fenômeno urbano. Evidenciar fenômenos onde a densidade é de fundamental importância, pelos mapas, é criar uma imagem onde a "razão entre a massa de uma substância localizada num espaço e a dimensão deste espaço" (LÉVY, 2003c, p.237) seja revelado.

É justamente este o sentido da anamorfose. Ela cria imagens de densidades. É "uma relação entre uma substância e uma extensão, está dotada de uma escala e de uma métrica" (LÉVY, 2003c, p.237). Variando o numerador e o denominador desta relação, estaremos variando a massa da substância que queremos revelar e a sua escala e métrica.

A anamorfose permite sair da ditadura da "superfície vazia". Essa ditadura faz dos objetos geográficos mais importantes, entre os quais as cidades, ocuparem freqüentemente um lugar muito limitado na carta por causa de sua densidade, que é justamente uma de suas características significativas. Tratando as superfícies de fundo de carta como entidades sensíveis às realidades a serem representadas, sai-se de um impasse. A extensão deixa de ser um 
componente intangível da carta e em entra em diálogo com a temática escolhida. (LÉVY, 2003a, p.74)

Anamorfose $^{13}$ vem do grego anamórphosis - transformação - imagem disforme. Em francês, "anamorphose" [anamorfose]; em inglês: Cartogram [cartograma], "variable scale maps" [mapas com escala varáveis] ou "value-by-area" cartograms [cartogramas de valores de áreas] e em alemão: "verzerrte Karte" [carta distorcida, disforme] (TOBLER, 2004, p.59-60).

Para Jacques Lévy (2003a, p.74 e 2005, p.6) anamorfose [anamorphose] é um procedimento efetuado sobre uma base cartográfica - fundo de carta permitindo estabelecer uma métrica diferente da euclidiana. Tal carta é denominada cartograma [cartogramme]. Sendo um procedimento, uma técnica, Lévy distingue dois tipos de procedimento: a anamorfose temática ou anamorfose comparativa: quando o tema e o fundo se confundem e é impossível introduzir um novo tema [Fundo = Tema]; e a anamorfose de fundo ou cartograma: quando este fundo é passível de ser explorado [Fundo + Tema]. São mapas "à leitura espacial" com um fundo de mapa significativo, conforme apresentado neste trabalho na figura 5 , pg. 39.

Devido ao uso polissêmico, em português e em outras línguas, do termo "cartograma"14 (como veremos na sequencia [Histórico]), adotaremos neste trabalho o termo mapa em anamorfose quando expressar fundo=tema e cartograma em anamorfose quando for fundo+tema.

Para Colette Cauvin (1995, p.269) anamorfose [anamorphose] é um caso particular de "transformação cartográfica espacial" [figura 12]:

A transformação cartográfica espacial é a passagem, graças a uma operação matemática (ou eventualmente gráfica), de uma forma do mapa a outra forma do mesmo espaço, privilegiando as mudanças dos "Iocalizantes" espaciais ${ }^{15}$. Desde que estas modificações originem "deformações" dos contornos, fala-se em anamorfose (CAUVIN, 1995, p.270).

\footnotetext{
13 Dicionário da Língua Portuguesa on-line da Porto Editora:<http://www.infopedia.pt> acesso: 10/9/2008

${ }^{14}$ Em seu Dicionário Cartográfico, Cêurio de Oliveira define "cartograma" como sendo um "mapa temático em qualquer escala, em que as intensidades de um fenômeno quantitativo nas diversas áreas são representadas mediante a intensidade do traço ou da cor" (OLIVEIRA, 1993, p.86). Brunet et al, (1993, p.91) adverte em seu dicionário que o termo "cartogramme" deve ser evitado pela sua ambiguidade que designa tanto uma carta estatística, ou que possui uma série de diagramas e anamorfoses do tipo que Cauvin irá chamar de transformações morfotemáticas.

${ }^{15}$ Localizantes espacias: Terminologia sugerida por S. Rimbert - suporte, fundo de referência, fundo de mapa/carta, descritos pelas letras XY, e, do outro, os "atributos" - variável temática, conteúdo ou dado temático - caracterizado pela letra Z (CAUVIN, 1995, p.306).
} 


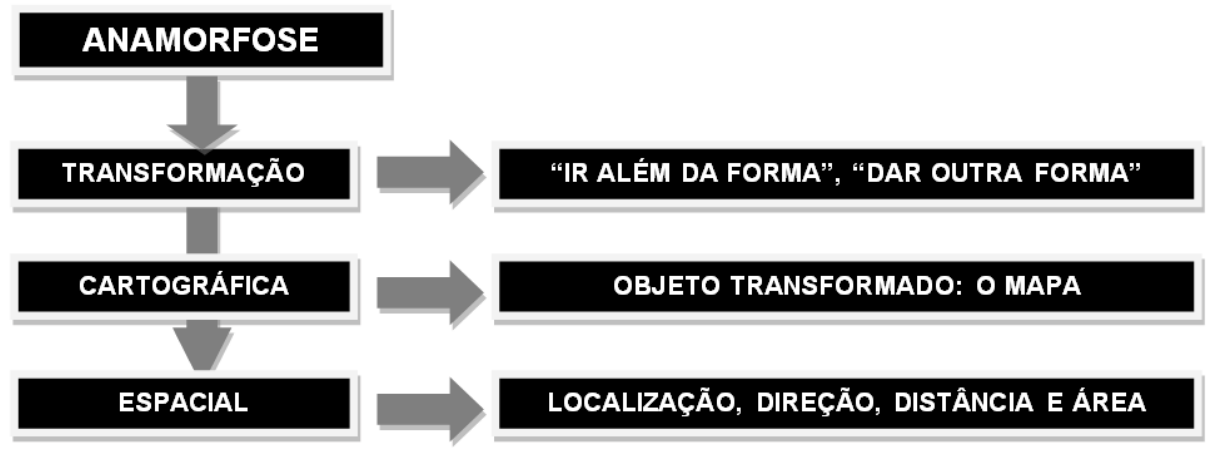

Figura 12 - - Anamorfose como transformação cartográfica espacial

Operar estas transformações espaciais em uma carta é privilegiar, primeiro, a função primordial de um mapa, que é a sua comunicação; segundo, como "instrumento de análise do espaço" (CAUVIN, 1995, p.270).

Cauvin (1995, p.272) estabelece três tipos de transformações espaciais:

1 - As transformações geométricas, que operam somente nas coordenadas espaciais/localizantes (XY) típicas dos sistemas de projeções cartográficas;

2 - Transformações morfotemáticas, que operam quando a variável temática/atributo $(Z)$ é aplicada ou integrada a $(X Y)$. Subdividem-se em dois grupos:

2.1 - Morfotemática de peso $=>$ quando a temática $(Z)$ exerce um "peso" uma "força" sobre a superfície dilatando e/ou contraindo o espaço;

2.2 - Morfotemática de ligação $=>$ distorção ou deslocamento proveniente de variáveis associadas ao espaço. A variável temática $(Z)$ não é exterior ao espaço considerado, mas é integrado, em particular com a distância.

Esta distância, pelas suas variações, intervém, de acordo com determinados critérios, para deslocar os lugares ou deformar a área estudada... As distâncias podem ser de natureza diferente: distância quilométrica, distância-tempo (tempo de ligação de duas cidades por automóvel) ou ainda distância-custo. (CAUVIN, 1995, p.284).

3 - Transformações morfodiferenciais $=>$ mudanças espaciais que traduzem diferenças entre "imagens"

...diferenças existentes entre imagens homólogas, exprimindo as distorções entre um espaço de referência e o espaço estudado (tempo, custo, etc) (CAUVIN, 1995 p.296). 
Na figura 13 vemos um exemplo da transformação morfotemática de ligação, datada de 1888, que substitui a distância euclidiana (quilômetros, metros) pela distância tempo. Mostra a redução do tempo com o uso de transporte à época das diligências, no final do século XIX (PALSKY, 1998, p.58 e CAUVIN et al, 2008, p.1819).

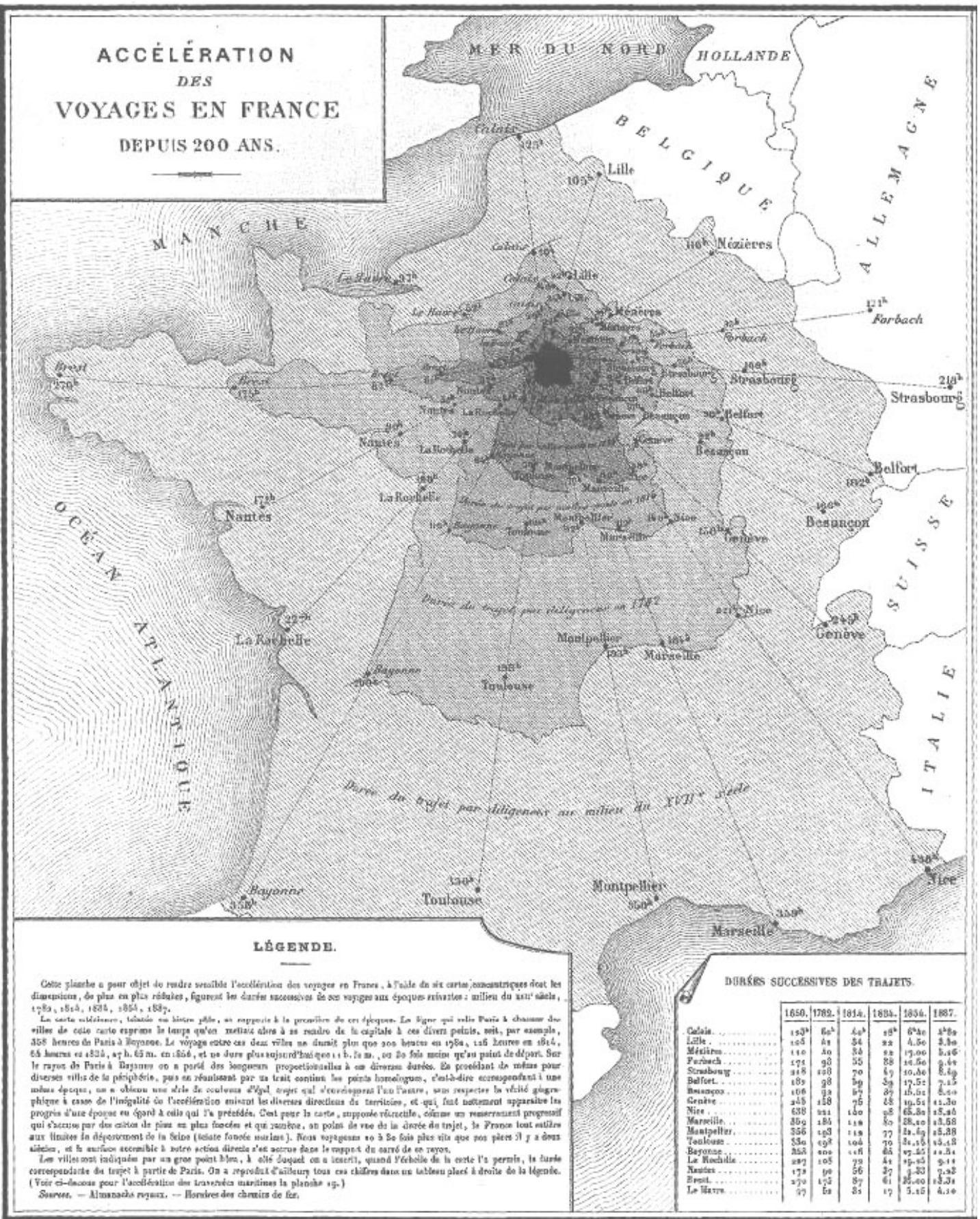

Figura 13 - "Accélération des voyages em France depuis 200 ans". Álbum de statistique graphique de 1887, Paris, 188, planche 8. Source: Bibliothèque Nationale de France, Paris. reproduzido de Palsky (1998, p.59). 
Outro exemplo clássico de transformação morfotemática de ligação é do geógrafo sueco T. Hägerstrand de 1957 - figura 14 - A visão do espaço sueco que possui um emigrante na cidade de Asby.

"Os lugares se encontram ligados à origem segundo uma função matemática " no caso a logarítmica - "que dilata o espaço em torno deste lugar e aproxima os mais afastados" (CAUVIN - 1995, p. 288)

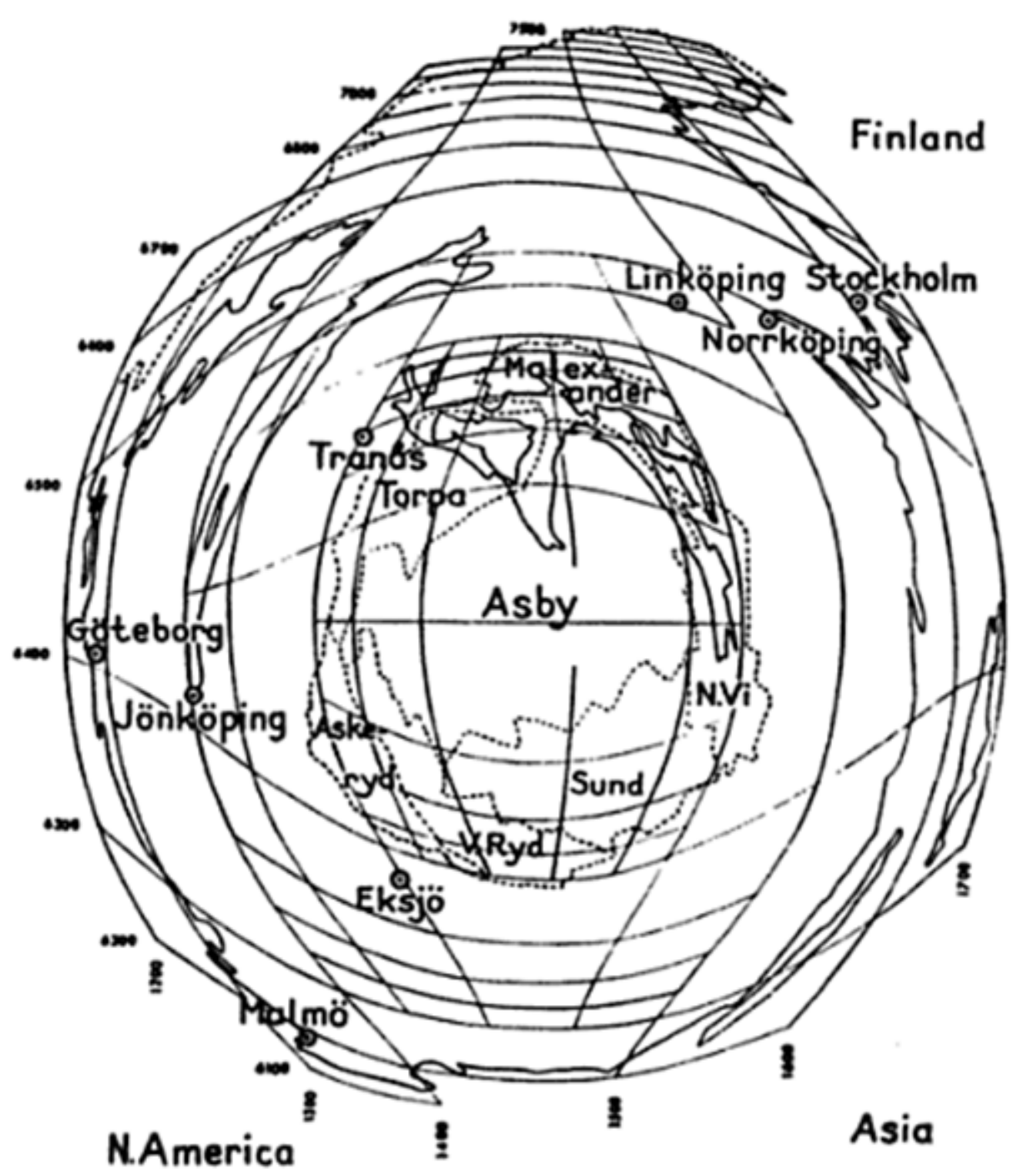

Figura 14 - transformação morfotemática de ligação - A visão do espaço sueco que possui um emigrante na cidade de Asby - reproduzido de Tobler (1963, p.92) 
No capítulo 3 já tratamos das transformações cartográficas e, segundo sua obra mais recente, Cauvin (2008) classifica a anamorfose como uma Transformação Cartográfica de Posição [TCP], onde os localizantes espaciais $[X, Y]$ serão função de [Z], isto é, $X=f[Z]$ e $Y=f[Z]$ (ver figura 4 na pg. 38).

Ainda segundo Cauvin (2008, p. 27-28) as Transformações Cartográficas de Posição [TCP] são classificadas em dois grandes grupos:

- TCP temáticas - que são subdivididas em TCP temáticas de peso e ligação e

- TCP diferenciais.

Nesse trabalho iremos apresentar/trabalhar basicamente - segundo a classificação de Collete Cauvin (1995) - com as transformações cartográficas morfotemáticas de peso ou, segundo a mesma Cauvin (2007 e 2008), com as Transformações cartográficas de posição temáticas de peso. Ambas têm o mesmo sentido.

\section{2 - Histórico}

O geógrafo norte-americano Waldo Rudolph $\operatorname{Tobler}^{16}$ foi o pioneiro ${ }^{17}$, na década de 60, ao estudar as transformações cartográficas espaciais - os cartogramas - e propor algoritmos matemáticos utilizando o computador. Usa computadores na pesquisa geográfica por mais de quarenta anos, com ênfase na modelagem matemática e em interpretações gráficas. Em sua tese de 1961 - "Map Transformations of Geographic Space" - ("Transformações cartográficas do espaço geográfico" - em tradução livre) já refletia que as representações espaciais do comportamento humano não poderiam ficar restritas a métricas euclidianas típicas dos mapas topográficos. Em suas palavras:

Muitos modelos geográficos e econômicos do comportamento humano, em um contexto espacial, indicam que a ferramenta de medição de um geodesista ou do topógrafo é menos relevante do

\footnotetext{
${ }^{16}$ Para consulta de alguns artigos de Waldo Tobler na internet: http://www.geog.ucsb.edu/ tobler/index.html Para uma pequena biografia: Em inglês: W. Toble., "Ma Vie: Growing Up in America and Europe", in Geographical Voices, W. Pitts and P. Gould, eds., University of Syracuse Press; Syracuse; 2002, pages 292-322.

Em francês : "Ma Vie: Grandir en Amerique et en Europe", dans Memoires de Géographes, P. Gould et A. Bailly, eds., Anthropos, Paris, 2000 p.209-242.

${ }^{17}$ No livro de Cauvin et al $(2007$, p.8) a influência de Tobler é evidente pelo agradecimento especial à ele dedicado: "A Waldo Tobler que abriu novos caminhos para a cartografia em seus estudos de transformações cartográficas".
} 
que um gradiente da distância em unidades temporais ou monetárias. É necessário tomar em consideração não somente a forma da terra, mas igualmente as realidades do transporte nesta superfície. Os automóveis, os trens, os aviões, e outros meios de transporte têm o poder de modificar as distâncias - medidas em unidades temporais ou monetárias - em uma maneira complicada. As relações diferentes da distância, entretanto, podem ser interpretadas como tipos diferentes de geometria. Uma aproximação geográfica natural é tentar traçar esta geometria a um plano, em uma maneira similar à preparação dos mapas da superfície terrestre. Se as transformações eram dependentes somente de um fator da proporcionalidade, como na conversão das milhas aos quilômetros, não haveria nenhuma dificuldade. Os fatos são consideravelmente mais complexos. A geometria que nós devemos tratar é raramente Euclidiana, e ela é, geralmente, impossível de preparar com um mapa plano que preserva todas as relações da distância (TOBLER, 1961, p.1, tradução nossa).

Em 2004, Tobler faz uma pequena revisão bibliográfica histórica da noção do termo "cartogram," encontrado em língua inglesa, francesa e alemã, baseada em sua apresentação do doutorado de 1961 e uma introdução do uso de algoritmos computacionais para a construção de cartogramas contíguos de valores de áreas, em seu artigo "Thirty Five Years of Computer Cartograms". Para Tobler (2004), a primeira referência ao termo "cartogram" (cartograma) se deve a Minard que "publicou em 1851 uma série de mapas chamados 'cartogrammes a foyer diagraphiques' ou mapas com diagramas" (FRISS ${ }^{18}$ apud TOBLER, 2004, p.59). termo não é citado em 1967 por Robinson ${ }^{19}$ em seu artigo sobre Minard, nem em seu livro de história da cartografia temática de $1982^{20}$. Somente menciona como mapas coropléticos, embora apresente ilustrações de diversos mapas de meados de 1800, que são cartogramas. Igualmente mostra um mapa elaborado por Minard em 1850 em que deliberadamente distorce as linhas de fluxo que representam a exportação de carvão da Inglaterra (ROBINSON, 1967, p.102) [ver figura 15].

A primeira vez que o termo "cartogram" aparece na International Cartographic Association é em Wallis e Robinson ${ }^{21}$ em 1987, mas não citam de onde o termo é derivado. O geógrafo americano John Kirtland Wright usa o termo em sua introdução ao Atlas Histórico de Paullin ${ }^{22}$ dos Estados Unidos, de 1932, e

\footnotetext{
${ }^{18}$ FRIIS, H. Statistical cartography in the United States prior to 1870 and the role of Joseph C. G. Kennedy and the U.S. Census Office. The American Cartographer 1 (2): 131-57.1974

${ }^{19}$ ROBINSON, A. The thematic maps of Charles Joseph Minard. Imago Mundi 21:95-108.1967

${ }^{20}$ ROBINSON, A. Early thematic mapping. Chicago: University of Chicago Press.1982

${ }^{21}$ WALLIS, H., and A. Robinson, eds. Cartographical innovations. Tring, Herts, U.K.: International Cartographic Association.1987

${ }^{22}$ PAULLIN, C. Atlas of the historical geography of United States. Washington, DC: Carnegie Institution and American Geographical Society.1932
} 
comenta que "um cartograma é um esquema cartográfico sobre o qual símbolos estatísticos são desenhados, mas que não se conformam estreitamente a distribuição real dos fenômenos representados". Tobler (2004) comenta que Wright "naturalmente está se referindo ao que é chamado agora de um mapa estatístico".

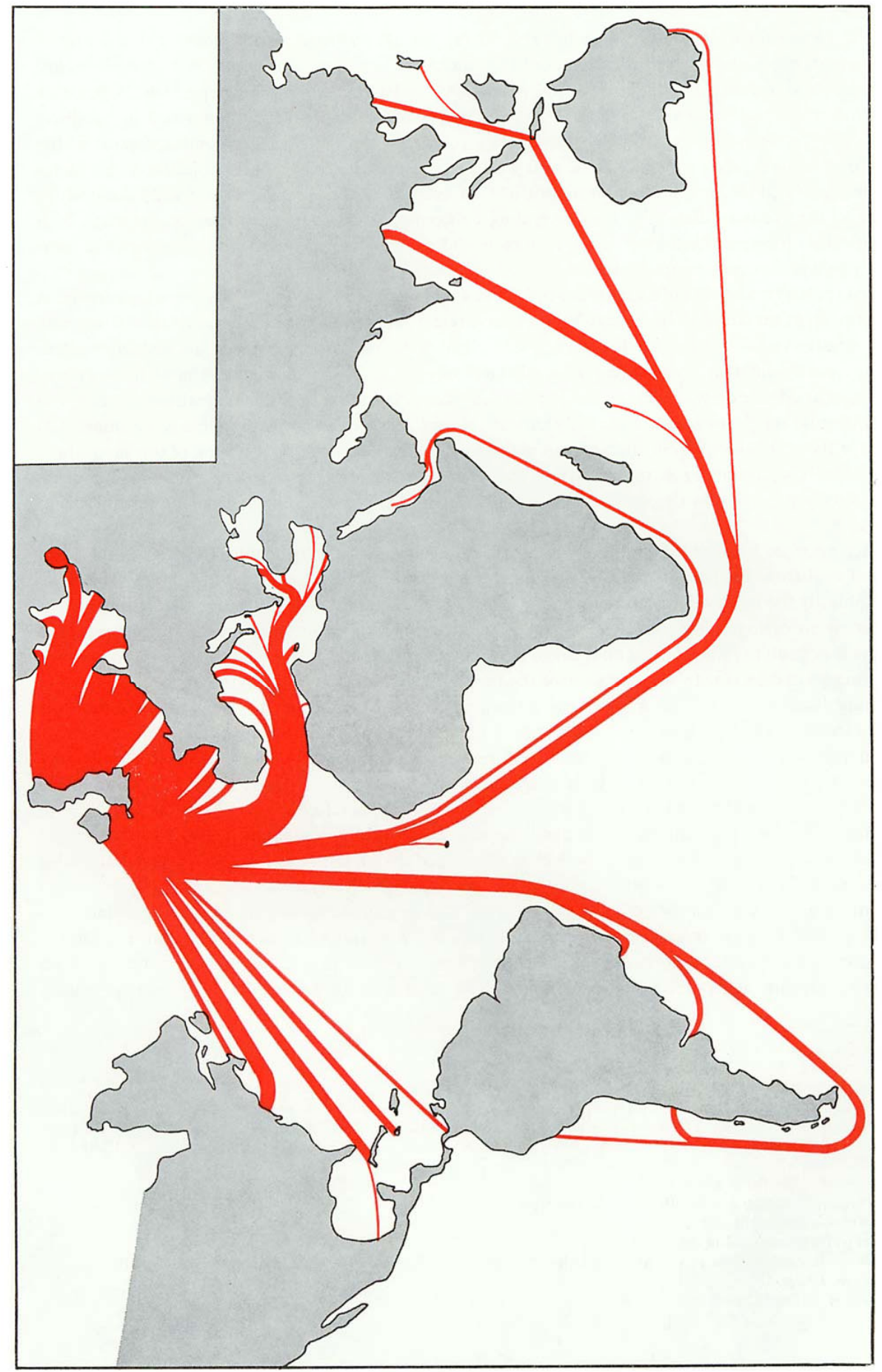

Figura 15 - Mapa de fluxo de exportação de carvão (Minard, 1850) reproduzido de Robinson (1967, p.102). 
Kretschmer e outros (1986, Vol. 1, página $396^{23}$ apud TOBLER, 2004) em sua história da cartografia, se refere ao termo "Kartogramm" como sendo um mapa coroplético ou como um mapa estatístico, mas igualmente se refere como um mapa "verzerrte" - distorcido - citado por Wiechel em 190324. Tobler (2004) faz ainda uma referência a um mapa da Alemanha de 1903 em que as estatísticas são mostradas em um mapa esquemático (Mayet ${ }^{25}$, 1905). Em 3 de novembro de 1929 o jornal norte-americano Washington Post publicou um mapa dos Estados Unidos com as áreas dos estados iguais à população e à tributação, acompanhado de uma proposta ao congresso para modificar o alocamento das tarifas [figura 16]. Este mapa agora seria chamado cartograma contíguo e mostra o estado de Pensilvânia ampliado, bem como os estados de Illinois (industrial), de Michigan, New York, New Jersey e de Ohio.

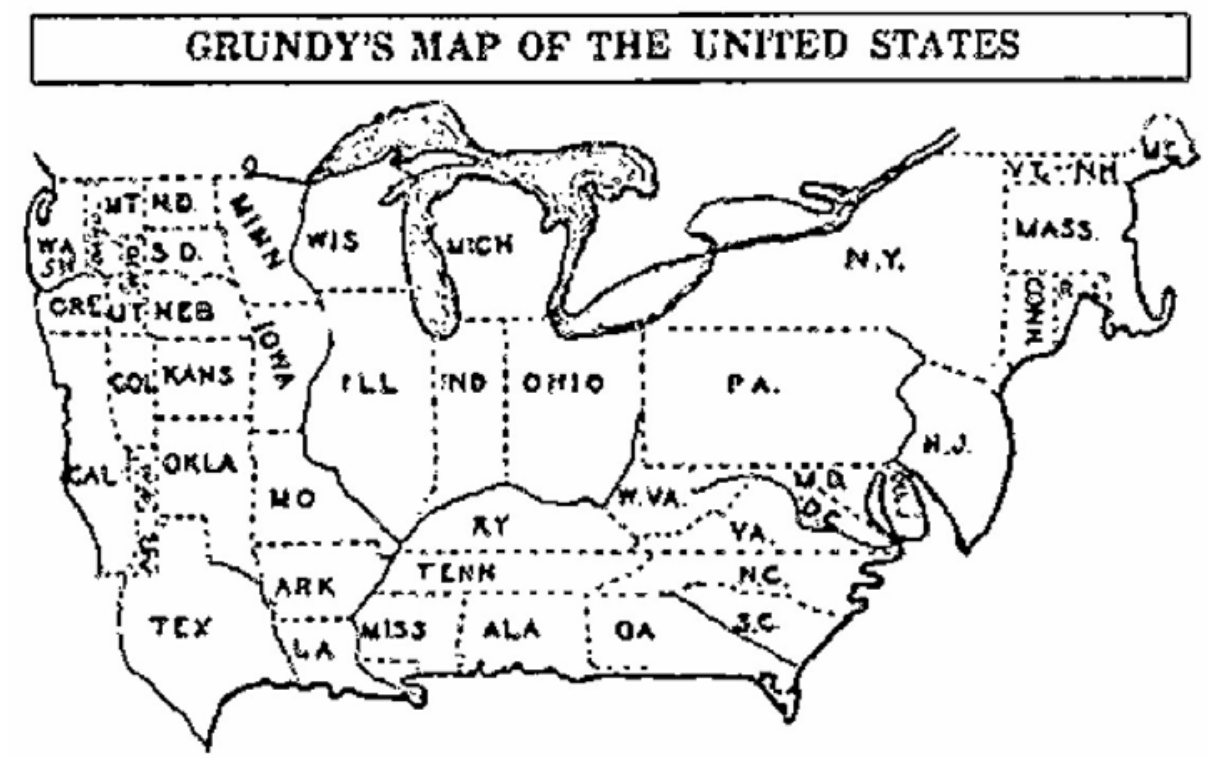

Figura 16 - Grundy's map of the United States - "Joseph R. Grundy, Pennsylvania manufacturer, suggested in the Senate lobby committee that the present equal power of States in voting on tariff bills is unfair because of differences in voting strength. Here's a map of the United States showing the size of each State on the basis of population and Federal Taxes." From the Washington Post November 3, 1929." reproduzido de Tobler (2004, p.59).

\footnotetext{
${ }^{23}$ KRETSCHMER, I., DORFLINGER, J. and WAWRIK, F. eds Lexikon zur geschichte der Kartographie. 2 vols. Wien: Deuticke. 1986

${ }^{24}$ WIECHEL, H. ZweiWahlkarten des Deutschen Reiches, Gotha. (Cited in Kretschmer et al., 1986, 397).1903.

${ }^{25}$ MAYET, P.Die schematischen-statistichen Karten des Kaiserlichen Statistischen Amtes zu Berlin. Bulletin de L'Institut International de Statistique 14, 3e liveraison: 214-22.1905
} 
Funkhouser $^{26}$ usou o termo "cartogram" repetidamente em sua história dos métodos gráficos (1937). Mas o uso que ele faz do termo "cartogram" significa o que nós chamamos agora de mapas coropléticos. (TOBLER, 2004, p.59, tradução nossa).

Erwin Raisz ${ }^{27}$, em 1938, no primeiro livro americano de cartografia, indica que o termo "cartogram é sujeito a muitas interpretações e definições":

O termo cartograma está sujeito a muitas interpretações e definições. Cada mapa tem início até um certo grau a partir da concepção original - um quadro de configuração da terra - em abstração, convencionalização e o emprego seletivo dos seus dados.

... Alguns autores, especialmente os europeus, chamam todo mapa estatístico de distribuição de cartograma, porque ele apresenta a configuração da distribuição de somente um elemento. Essa idéia, apesar de justificada, é um pouco contrária ao uso dos americanos... O uso mais conservador do termo é para aqueles mapas nos quais os contornos uniformes do terreno ou as locações exatas dos outros detalhes são alterados... As Tábuas Romanas de Peutinger são cartogramas típicos e também os mapas "T - O" da idade média. (RAIZ, 1969, p.263)

Raiz (1969) define os cartogramas de valores de áreas da seguinte forma:

Nestes cartogramas, uma região, país, ou continente está subdividido em regiões menores, cada uma das quais está representada por um retângulo. Este retângulo é proporcional em área ao valor que ele representa em certas distribuições estatísticas. As regiões são agrupadas aproximadamente nas mesmas posições como elas estão no mapa. (RAIZ, 1969, p.264)

Em seu artigo "The Rectangular Statistical Cartogram" Raiz afirma:

Deve-se enfatizar que o cartograma estatístico não é um mapa. Embora tenha aproximadamente as proporções do país e retenha, tão distante quanto possível, as posições relativas das várias regiões, o cartograma é puramente um projeto geométrico para visualizar determinados fatos estatísticos e para elaborar determinados problemas da distribuição. Os exemplos destes cartogramas são dados nas figuras de acompanhamento. (RAIZ, 1934, p.292) - [ver figura 17].

Tobler (2004) cita ainda Raisz que em sua obra de $1962^{28}$ indica que "um cartograma pode ser definido como um diagrammatic map."'Isto sugere que o termo cartogram é uma contração das duas palavras, dada a flexibilidade da língua inglesa em construir tais combinações.

\footnotetext{
${ }^{26}$ FUNKHOUSER, H. Gray. Historical Development of the Graphical Representation of Statistical Data. Osiris, Vol. 3, p.269-404.1937

${ }^{27}$ RAISZ, Erwin.General cartography. New York: McGraw Hill. 1938.

${ }^{28}$ RAISZ, Erwin.Principles of cartography. New York: McGraw Hill.1962.
} 


\section{LAND AREA}

U.S.total 2.973 .776 square miles

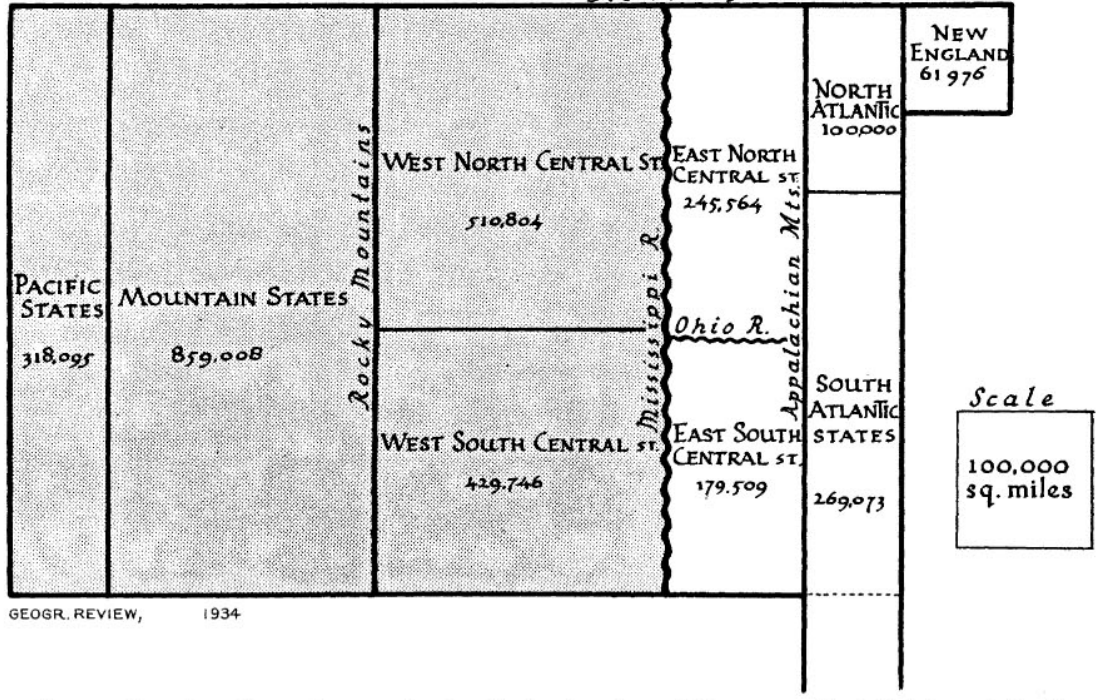

FIG. I-A rectangular cartogram showing the land surface of the geographical divisions of the Census. This figure is intended for comparison with the following cartograms.

\section{POPULATION 1930 census. U.S. total 123.6 million}

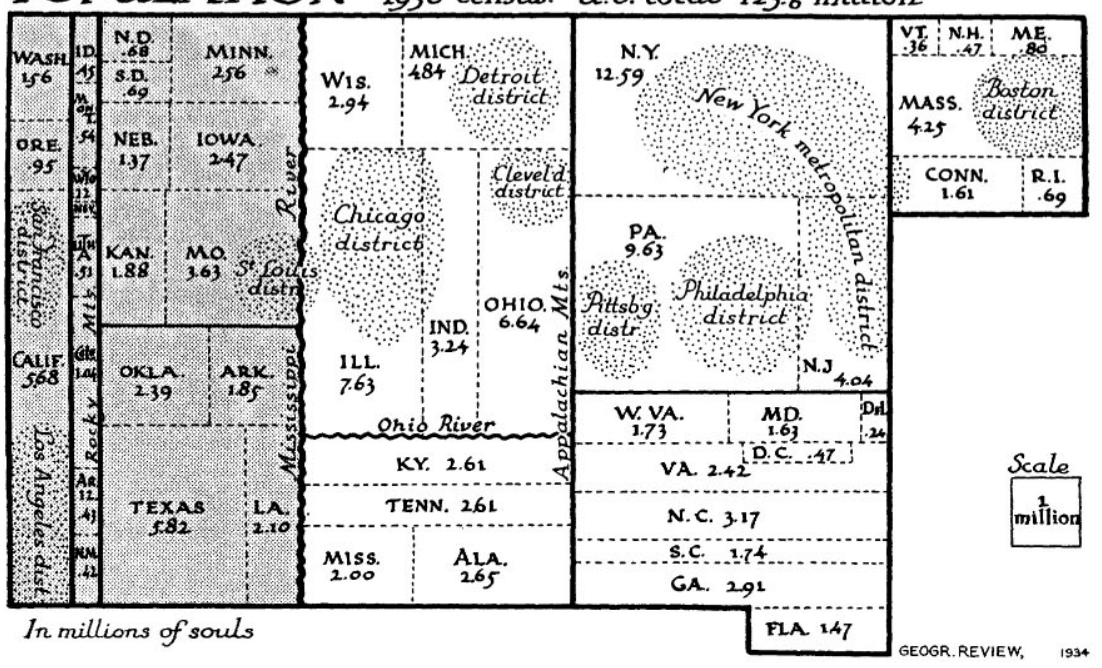

FIG. 2-Rectangular statistical cartogram with rectangles representing geographical divisions of the Census and states proportionate in size to their population. Note the position of the Mississippi River (the area west of the Mississippi is shaded in all of the cartograms).

The metropolitan districts of the largest cities (Census Bureau) are shown by a dotted area also proportionate in size to their population.

Figura 17 - Cartogramas retangulares estatísticos de Raiz (1936, p.293). Estes mapas também estão presentes no artigo de Tobler (2004, p.59).

Funkhouser (1937, p.356), citado também por Tobler (2004), apresenta realmente um mapa que agora pode ser chamado de cartograma de valores de áreas. Este é um mapa dos países da Europa em que cada país é representado por um quadrado cujo tamanho é proporcional à área do país, e com os países em suas posições e adjacências aproximadamente corretas [figura 18]. O mapa é datado de 1870 e foi usado pelo educador francês Pierre Ismile Levasseur (1828-1911) em um de seus livros texto de geografia. 


\section{STATISTIQUE FIGURATIVE}

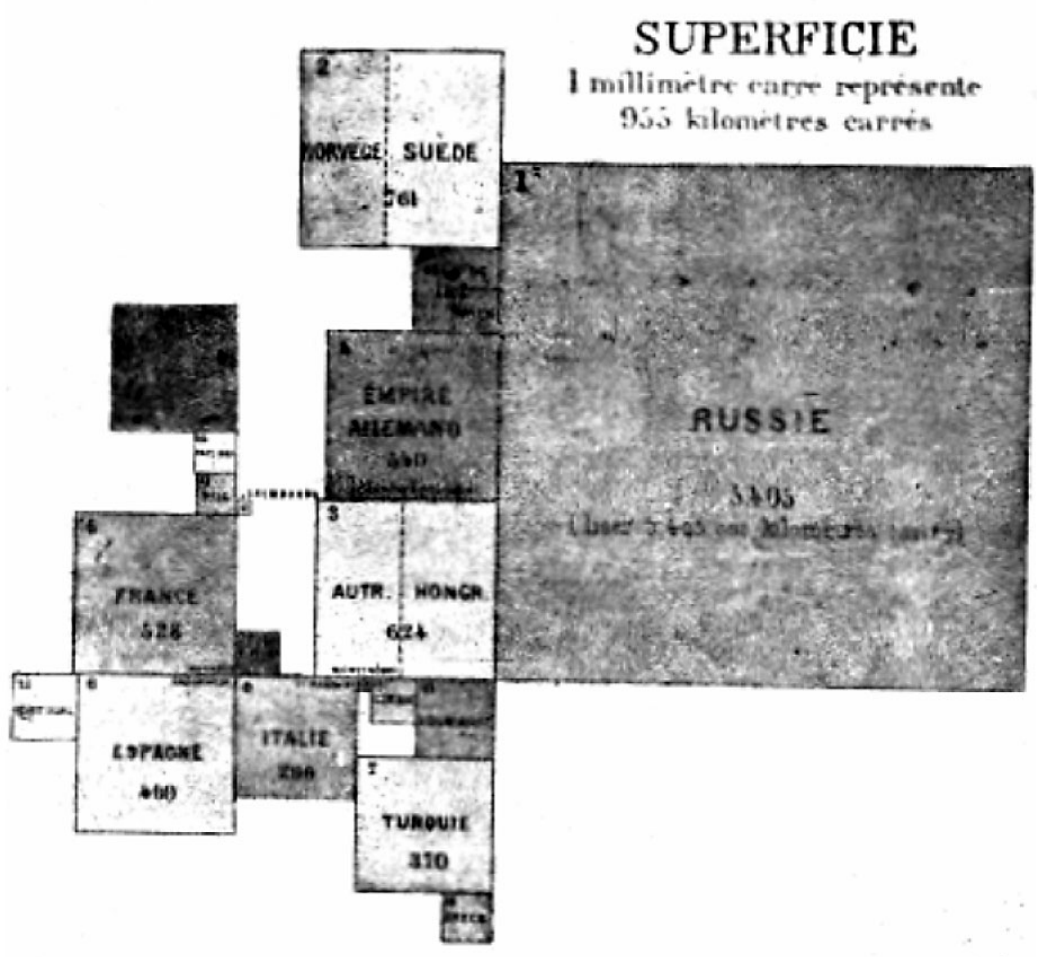

Figura 18 - Stastistique Figurative

Para Funkhouser este é um tipo de gráfico estatístico usado por Levasser em 1870, como "ilustração" em seu livro de geografia (TOBLER, 2004, p.59)

Em sua tese de 1961 Tobler dedica um pequeno capítulo aos cartogramas e o transforma em artigo em $1963^{29}$, complementando-o com os cálculos matemáticos necessários à sua implementação. Neste ano - 1961 - Tobler assume na Universidade de Michigan a cadeira de professor assistente de Geografia e transforma a suas formulações em programas computacionais para elaborar os seus cartogramas e, por volta de 1967, obtém os primeiros resultados [figura 19].

Tobler distribuiu diversos programas na linguagem FORTRAN em um relatório interno ao Departamento de Geografia da Universidade de Michigan e já na Universidade da Califórnia - Santa Barbara ${ }^{30}$ - vários destes programas foram executados em um Tektronix 4054. Os resultados foram expostos em uma conferência em $1984^{31}$. Um exemplo é mostrado na figura 20. (TOBLER, 2004, p.66)

\footnotetext{
${ }^{29}$ TOBLER, W.Geographic area and map projections. The Geographical Review 53:59-78.1963.

${ }^{30}$ Tobler foi pesquisador na Universidade de Michigan de 1961 a 1977. Em 1977 assume como pesquisador na Universidade da Califórnia - Santa Barbara onde hoje é professor emérito. Disponível em: <http://www.geog.ucsb.edu/ tobler/index.html>. Acesso: 24/09/2007

31 TOBLER, W.Interactive construction of contiguous cartograms.ComputerGraphics 84, 13 17.Anaheim,CA: National Computer Graphics Association Conference.1984.
} 


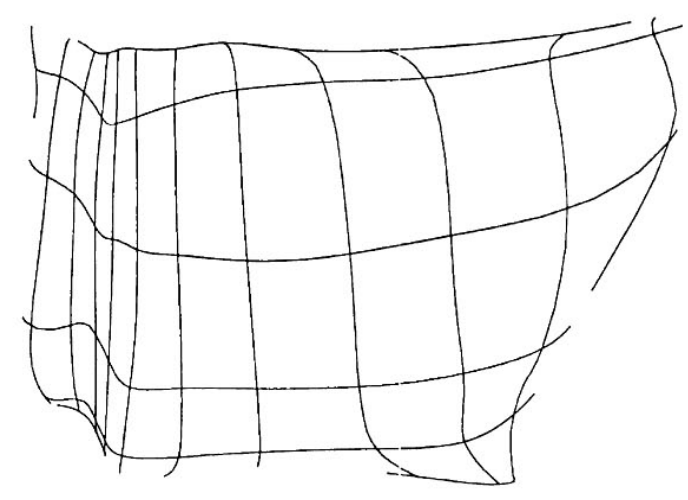

Figure 14. The latitude-longitude graticule for a cartogram of the United States. Computed by the author.

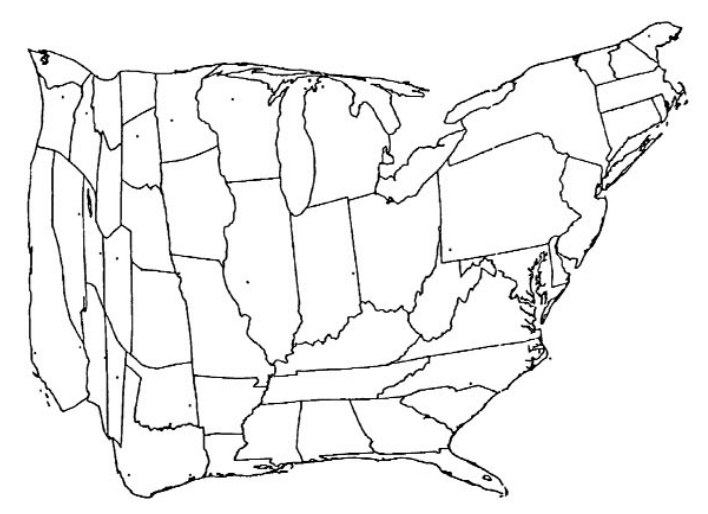

Figure 15. The United States drawn according to the projection graticule of Figure 14. Computed by the author.

Figura 19 - Primeiros resultados de Tobler com cartogramas oriundos de programas computacionais - reprodução de Tobler (2004, p.64).

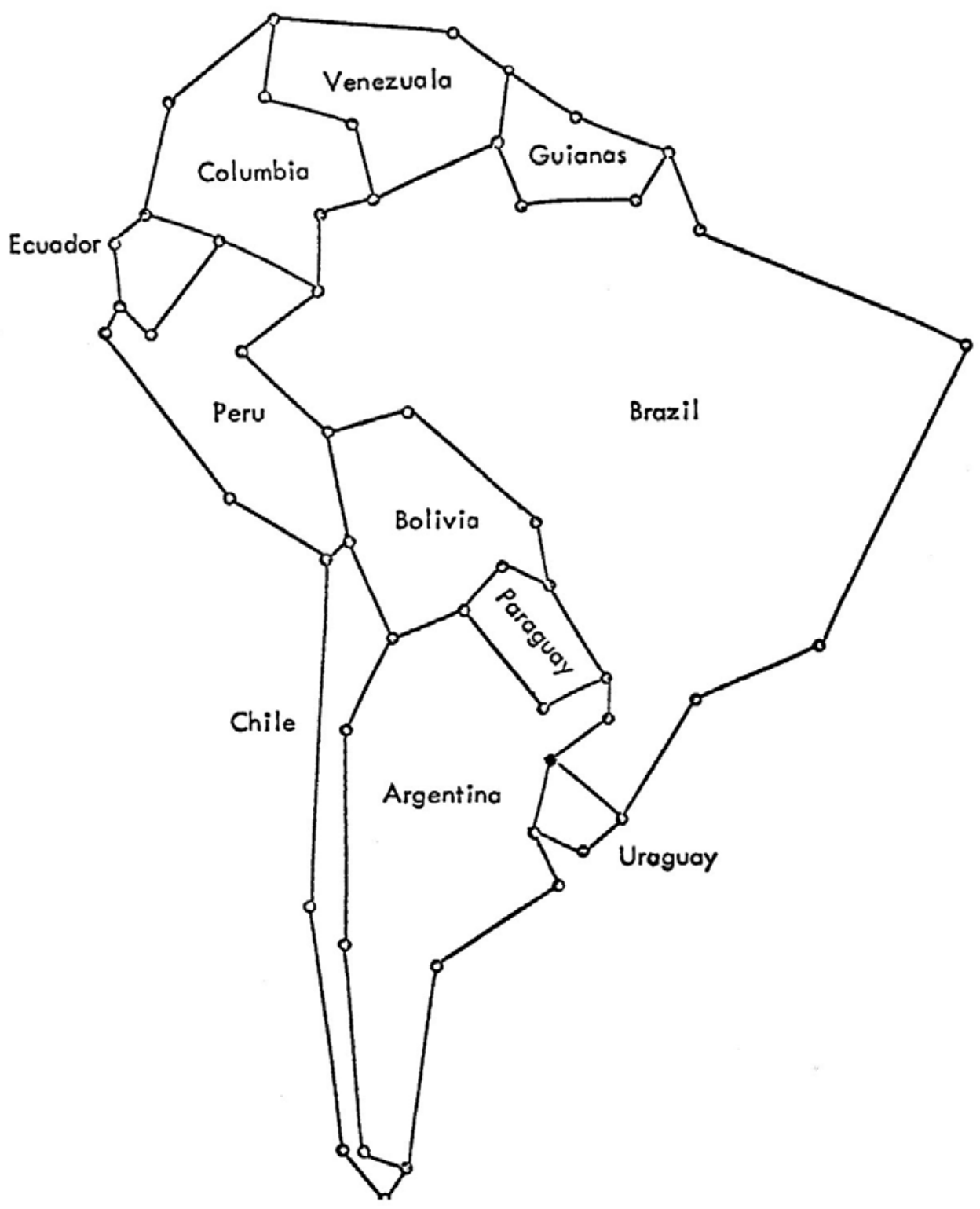

Figura 20 - Cartograma da Amércia do Sul

Exemplo de cartograma apresentado em conferência de 1984 reprodução de Tobler (1984, p.4). 
Em 1971 Ruston $^{32}$ publicou um programa de computação baseado em uma analogia da Física. Imagine uma folha fina da borracha coberta com uma distribuição desigual de pontos cobertos que representam uma distribuição do interesse. O objetivo é esticar o necessário a borracha tanto quanto até que os pontos estiverem distribuídos uniformemente na folha. Esta descrição simples é uma representação aproximada da indicação matemática usada pelo seu algoritmo. Se os pontos representam a distribuição, por exemplo, da população, o cartograma resultante é tal que as áreas do mapa são proporcionais à população, quando a folha de borracha for relaxada a sua forma volta ao original. (TOBLER, 2004, p.67, tradução nossa)

Após estes estudos iniciais realizados por Tobler na década de 80 e posteriormente, vários autores desenvolveram novos algoritmos para elaborar cartogramas. Em 1985 Dougenik (DOUGENIK et al, 1985) desenvolve o seu método baseado no conceito de campos de força da física, particularmente onde as forças são inversamente proporcionais à distância, como em campos elétricos e gravitacionais. Aplica assim um modelo de forças que são exercidas em cada centróide de um polígono de um fundo de mapa, atuando em suas coordenadas na proporção inversa à distância.

Baseado no algoritmo desenvolvido por Dougenik, Eric Bradway Wolf da University of Tennessee at Chattanooga implementa, em Visual Basic for Applications (VBA), um script para o aplicativo da Environmental Systems Research Institute (ESRI) - ARCGIS 9. Chamado de "CartogramCreator" gera cartogramas contínuos, não contínuos e cartogramas circulares (WOLF, 2007). Em 2005 Adrian Herzog, do Departamento de Geografia da Universidade de Zurich (TOBLER, 2004) desenvolve, na linguagem de programação Java (desenvolvida pela empresa Sun Microsystems), um programa interativo para a internet ${ }^{33}$.

\section{3 - Aplicativos, aplicações e resultados}

Em nossas pesquisas sobre anamorfose/cartogramas realizamos, em 2007, as primeiras experiências com o script desenvolvido por Wolf ${ }^{34}$ [Cartogram Creator] no aplicativo da ESRI [Environmental Systems Research Institute]- ArcGis 9.1. Testamos, em 2008, outro script para ArcGis desenvolvido na linguagem C++ por Tom Gross ${ }^{35}$, "Geoprocessing Tool to make Cartograms", baseado em algoritmos

\footnotetext{
${ }^{32}$ RUSTON, G. Map transformations of point patterns: Central place patterns in areas of variable population density. Papers and Proceedings of the Regional Science Association, 28:11129.1971.

${ }_{33}$ Disponível na internet em: <http://www.mapresso.com/index.html>, acesso: 9/04/2007

34 Disponível para download no site da ESRI: <http://arcscripts.esri.com>, acesso: 9/04/2007

${ }^{35}$ Disponível para download no site da ESRI: <http://arcscripts.esri.com>, acesso: 24/01/2008
} 
desenvolvidos pelos físicos Michael T. Gastner e M. E. J. Newman (2004) no artigo Diffusion-based method for producing density equalizing maps ${ }^{36}$.

Cartograma de difusão: Em um cartograma de população, esta é necessariamente uniforme, uma vez que as áreas das regiões são escaladas para serem proporcionais à sua população. Por definição, a densidade demográfica é igual em todas as partes destas áreas. Criar um cartograma dando uma densidade demográfica particular, é permitir que a população, de alguma maneira, flua das áreas de alta densidade para as de baixa densidade, pois a densidade é igual em toda parte desta área. Um processo candidato a esta analogia é o processo de difusão ${ }^{37}$ linear em Física. Dizemos que uma população [o] é função da densidade [r], onde $r$ representa a posição geográfica - permitimos então que essa densidade se difunda. No limite de um longo tempo $t[t=>\infty$ ] a densidade demográfica se torna uniforme e este deslocamento total, desde seu inicio até o seu termino, determina a projeção do mapa necessário para produzir um cartograma de densidade perfeitamente equalizado. Esta é a base para nosso método de construir um cartograma (GASTNER e NEWMAN, 2004, p.7500, tradução e adaptação nossa).

Os resultados de nossos testes são mostrados no mapa11 e provavelmente é o primeiro mapa em anamorfose elaborado no Brasil [2007], com o script desenvolvido por Wolf em ArcGis. A substância escolhida foi a população residente em cada distrito do município de São Paulo no ano de 2000. O fundo de mapa tradicional foi transformado. As áreas dos polígonos ficaram proporcionais ao "peso" [transformação cartográfica morfotemática de peso] de cada homem, mulher e criança residente nos distrito do município. A forma de medir a distância - a sua métrica - no mapa foi alterada: de $\mathrm{km}$ lineares ou $\mathrm{km}^{2}$ do mapa euclidiano representado ao lado da anamorfose, para um número proporcional aos seus habitantes residentes. No mapa 12A [em 2008] a mesma substância foi utilizada população residente - baseada no método de difusão, para testar o script de Tom

\footnotetext{
${ }^{36}$ No site de Mark Newman é disponibilizado o aplicativo desenvolvido por Newman\&Gastner - "Cart" em Visual C++: http://www-personal.umich.edu/ mejn/cart/, Acesso: 06/04/2008.

Mapas do projeto "The Worldmapper Project collection of cartograms" encontram-se diversos cartogramas baseado no método dos autores: http://www.worldmapper.org/. Acesso: 06/04/2008. Cartogramas da eleição presidencial dos EUA de 2008 são disponibilizados por Newman em: http://www.santafe.edu/ mgastner/cartogram/election08/election08.html - Acesso: 5/01/2009

${ }^{37}$ A experiência nos demonstra que quando abrimos um frasco de perfume ou de qualquer outro líquido volátil, podemos sentir rapidamente em um recinto fechado. Dizemos que as moléculas do líquido depois de evaporar-se se difundem pelo ar, distribuindo-se em todo o espaço circundante. $\mathrm{O}$ mesmo ocorre se colocarmos um pouco de açúcar em um vaso de água, as moléculas de sacarose se difundem por toda a água. Estes e outros exemplos nos mostram que para que aconteça o fenômeno da difusão, a distribuição espacial de moléculas não deve ser homogênea, deve existir uma diferença, ou gradiente de concentração entre dois pontos do meio. Lei de Fick em: <http://www.fisica.ufs.br/CorpoDocente/egsantana/transporte/difusion/difusion.htm>. Acesso: 23/01/2009.
} 
Gross. Em 12B o fundo de mapa é igual à renda média em unidades monetárias [Reais - $R \$$ ] que cada homem/mulher residente recebe pelo seu trabalho. A métrica será então renda [o tema e o fundo se confundem!].

\section{Município de São Paulo - Distritos - 2000}

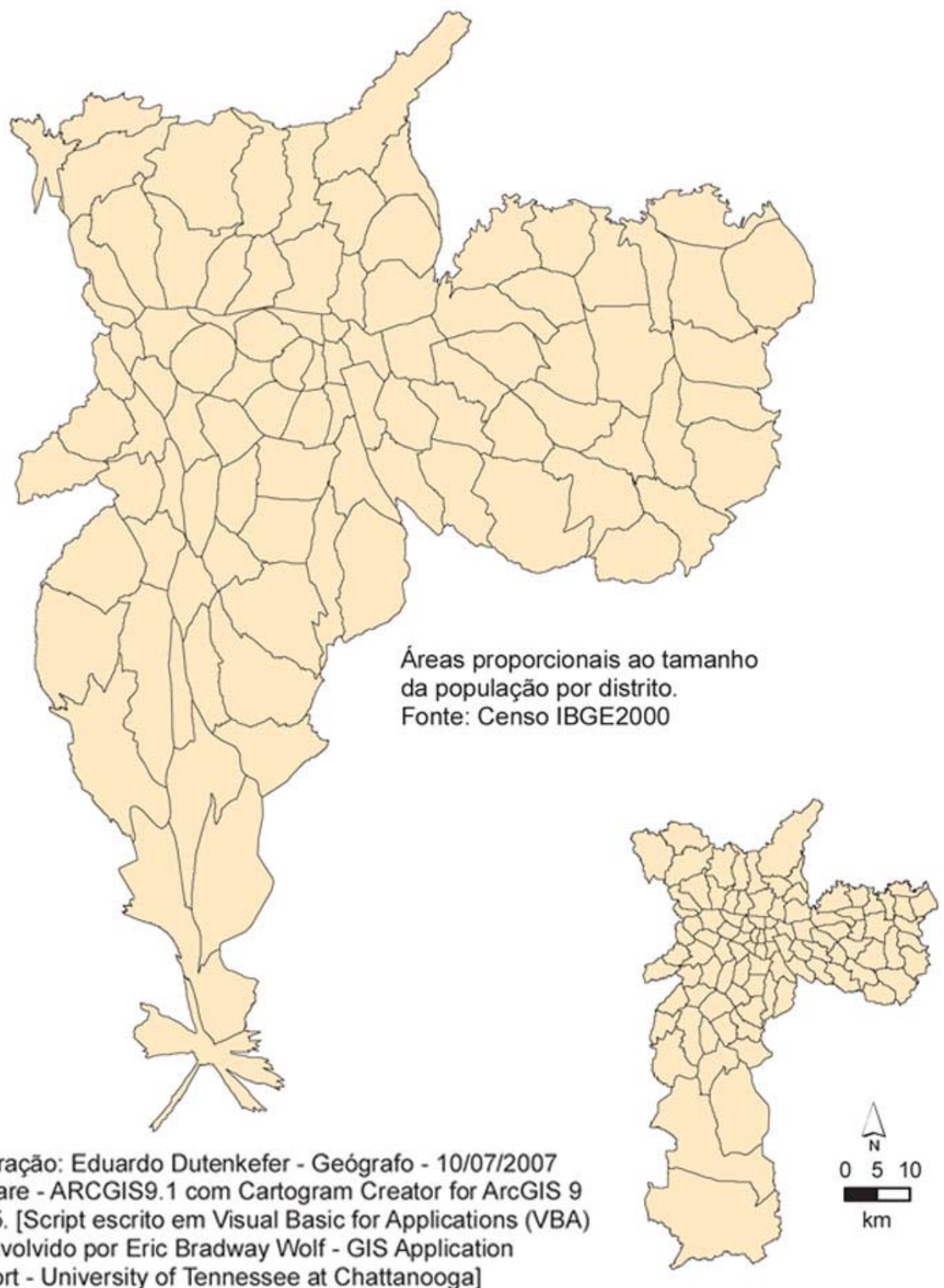

Projeçăo Universal Transversa de Mercator Datum: SAD 1969 UTM Zona 23S

Mapa 11: Mapa em anamorfose da população residente nos distritos do município de São Paulo 
No mapa 13 o mapa em anamorfose da metrópole paulista foi elaborado com o aplicativo ScapeToad ${ }^{38}$, que foi desenvolvido por Dominique Andrieu (Maison des Sciences de l'Homme, Université François-Rabelais, Tours), Christian Kaiser (91nord, Basel, Lausanne) e André Ourednik (Chôros Laboratory, EPFL-ENACINTER). Escrito em Java [código aberto] e projetado como uma aplicação independente usando o formato da ESRI - Shapefile - para a entrada e a saída de bases cartográficas em formato vetorial. Também é baseado no método de Gastner T.M. \& Newman M.E.J., "Diffusion-based method for producing density-equalizing maps" [figura 21].

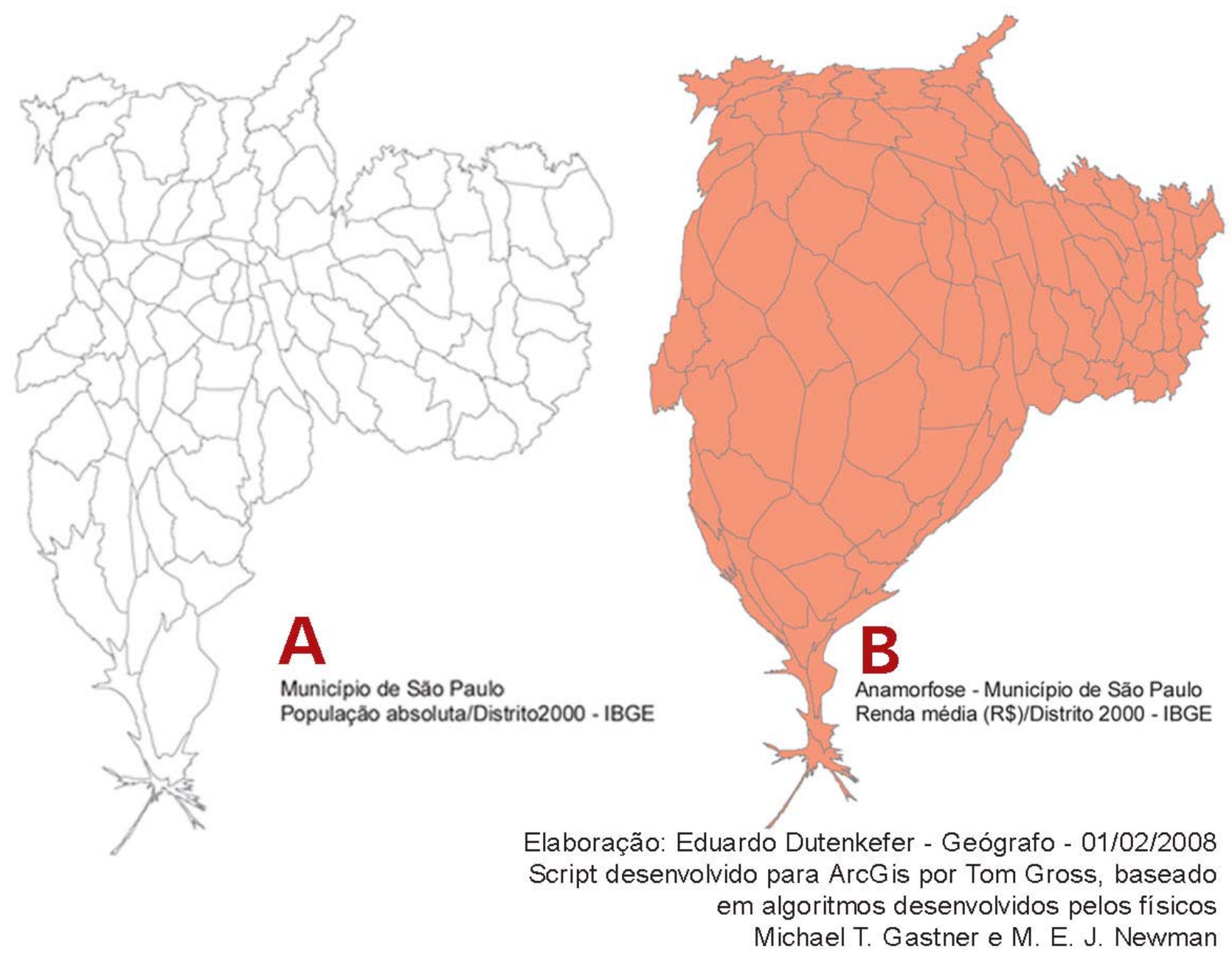

Mapa 12: A:- Mapa em anamorfose da população residente nos distritos do município de São Paulo

B: Mapa em anamorfose da renda média nos distritos do município de São Paulo

\footnotetext{
${ }^{38} \mathrm{~A}$ base de informações desta página e da imagem da página seguinte disponíveis em: <http://chorogram.choros.ch/scapetoad/index.php>. Acesso: 13/05/2008 - (tradução nossa)
} 


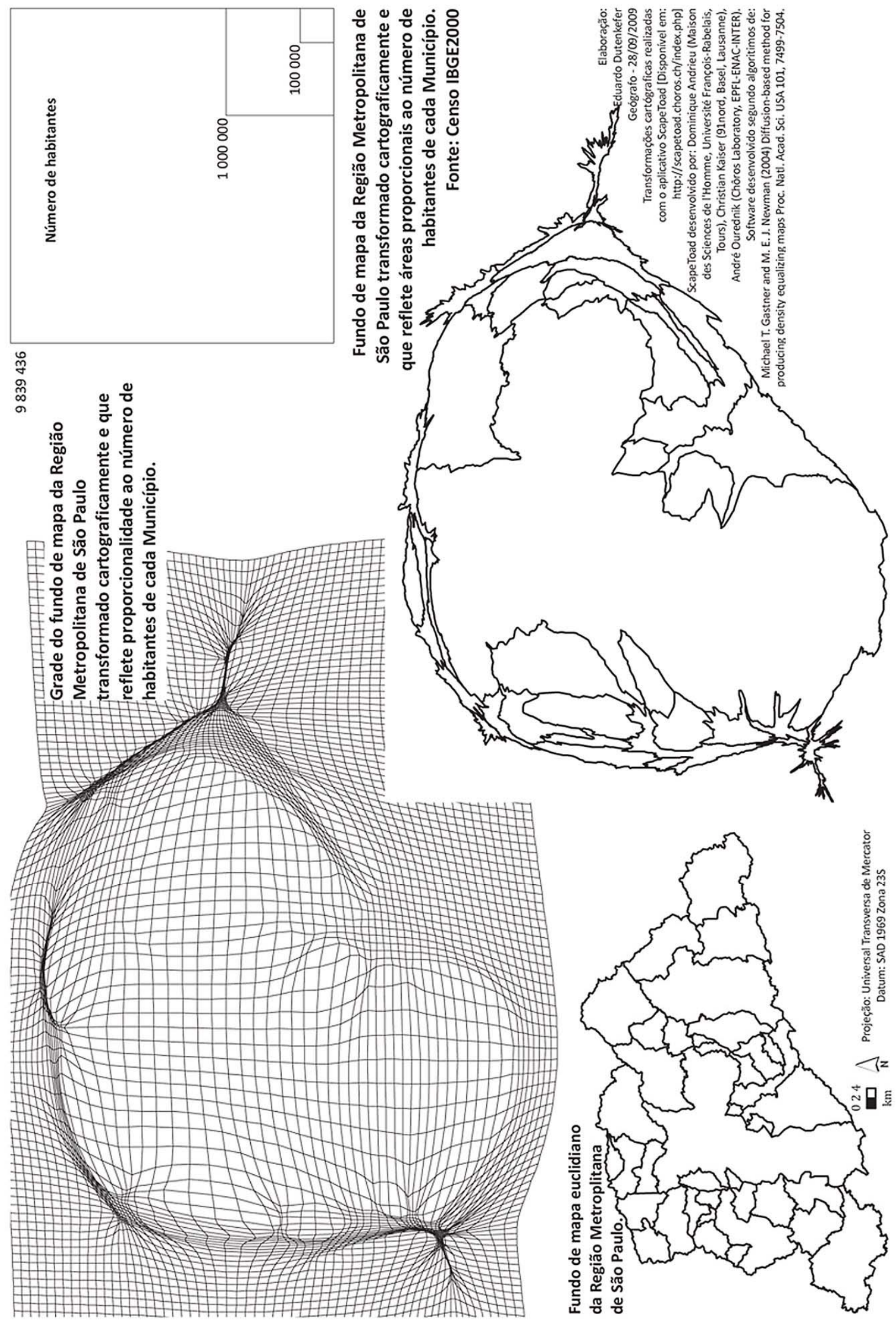

Mapa 13 - mapa em anamorfose da metrópole paulista 


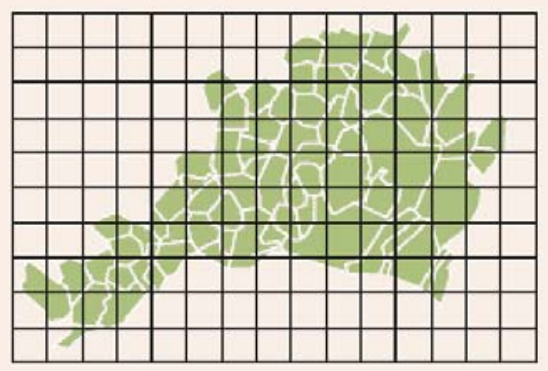

0 software coloca uma grade regular sobre todas as camadas (definidas geralmente de acordo com métricas topográficas)

... computa a densidade para cada ponto de grade...

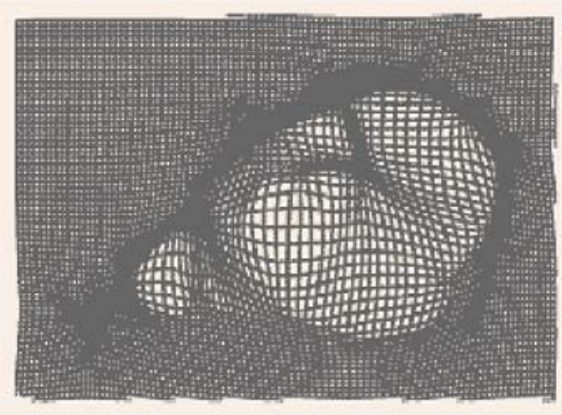

... e aplica 0 algoritmo de Gastner/Newman e

"tenta" respeitar os confinamentos da forma. [fundo de carta]

os "mapas-áreas" refletem agora variáveis definidas pelo utilizador.
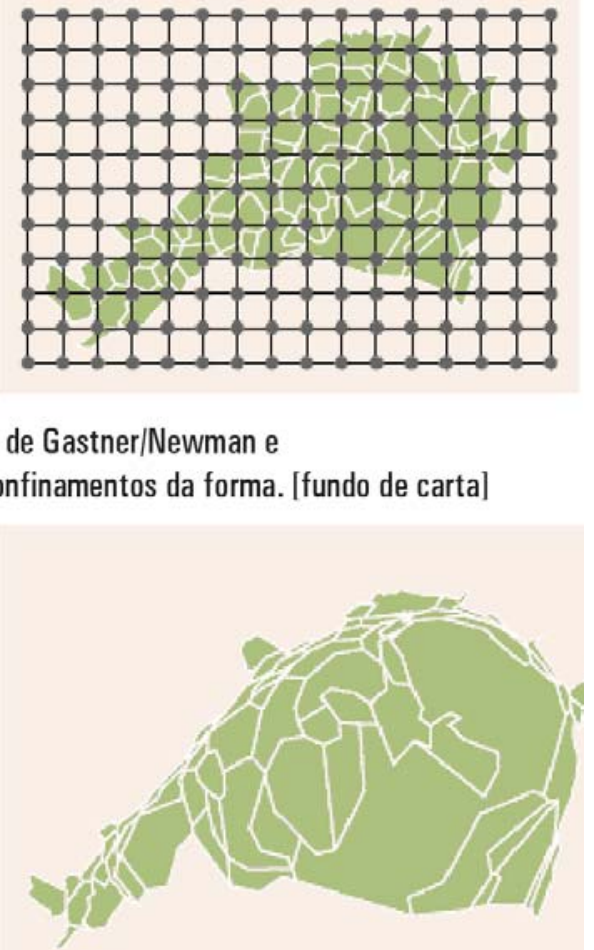

Figura 21: Sequência que o programa Scape Toad usa como princípio de seu processamento na transformação de um fundo de mapa em outro.

O diferencial deste aplicativo é que permite a introdução de uma "escala" [não em métricas euclidianas] - no exemplo representado por quadrados que são proporcionais ao número de habitantes - e um "grid" [grade] que proporciona uma imagem impactante do fenômeno cartografado.

Com este aplicativo executamos outros testes, como no mapa 14 , onde tratamos o fundo de carta com a quantidade de habitantes por distrito do município de São Paulo e agregamos, junto, uma base viária. O aplicativo processa ao mesmo tempo as duas bases indicadas. Proporciona uma imagem de densidade de população e de rede ao mesmo tempo. No mapa 15 processamos a população urbana e rural dos municípios que compõem a região Administrativa de São José dos Campos - Estado de São Paulo. 


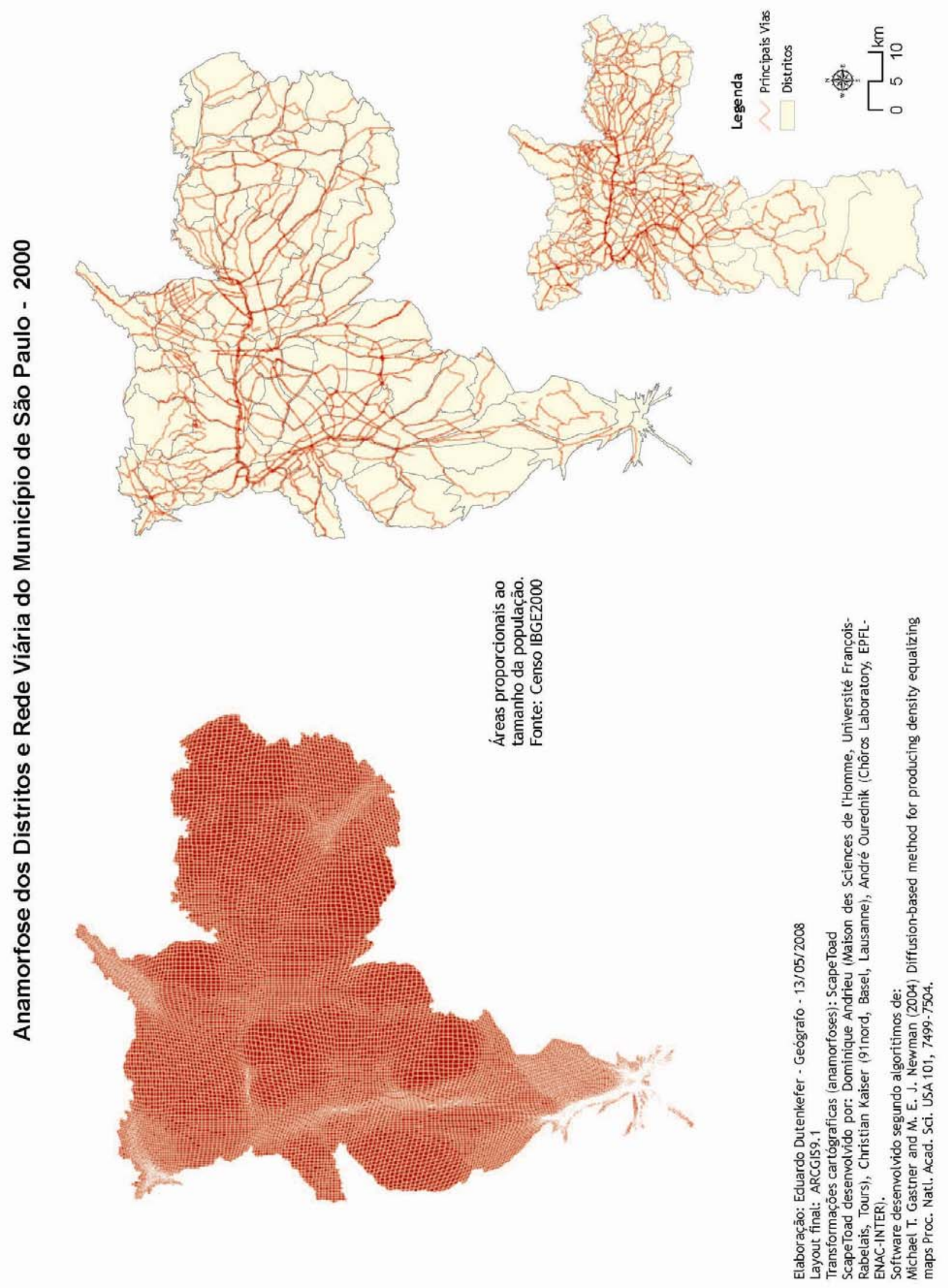

Mapa 14 - Mapa em anamorfose da população dos distritos do município de São Paulo e sua rede viária. [Processado no ScapeToad] 

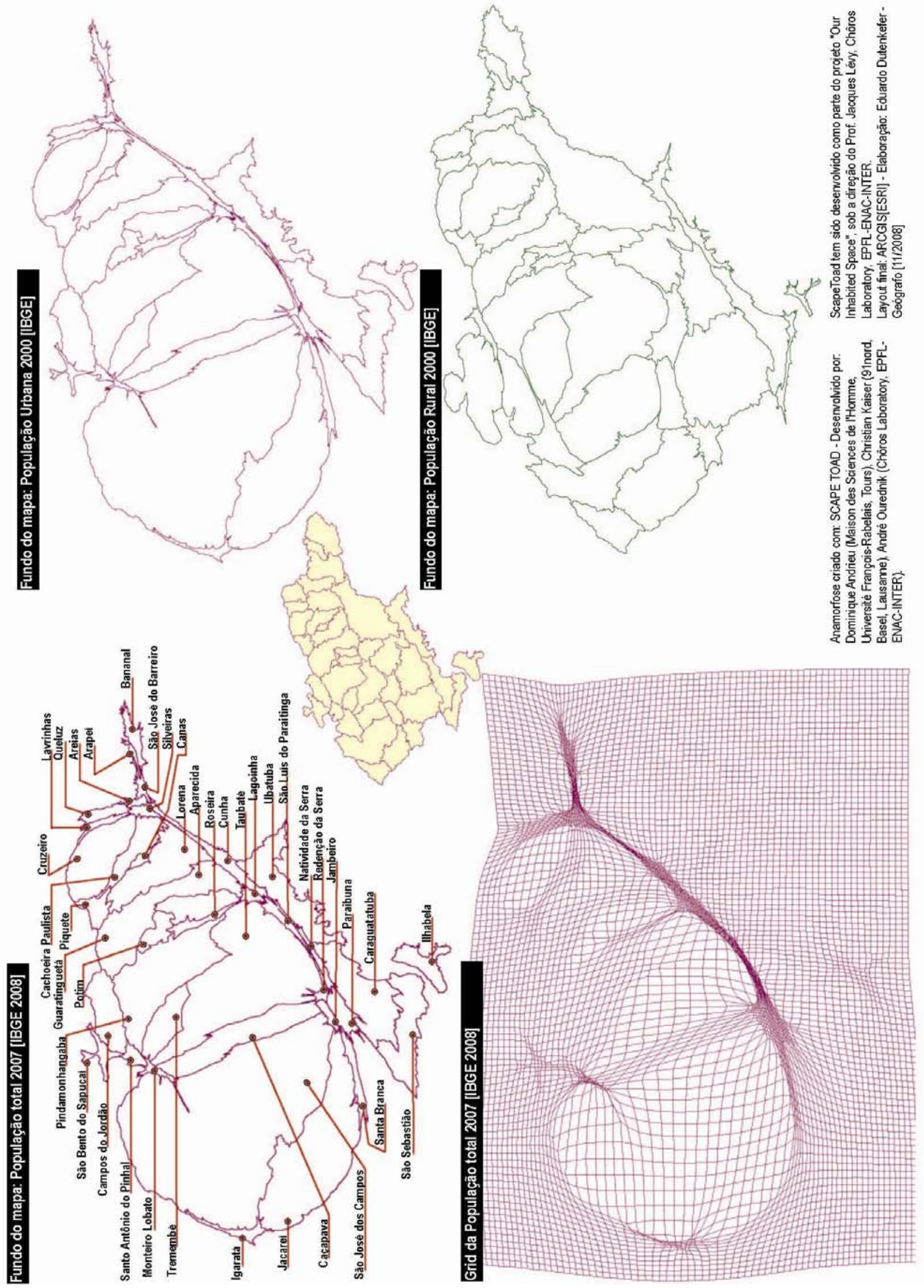

Mapa 15 - Mapa em anamorfose da População Urbana e Rural dos municípios que compõem a região Administrativa de São José dos Campos - Estado de São Paulo.

[Processado no ScapeToad] 
Fizemos um teste com os mapas dasimétricos do capítulo 4, mapas 5 e 7 . No mapa 16 temos um mapa em anamorfose do dasimétrico da metrópole de São Paulo e no mapa 17, do município de Osasco. O aplicativo "Scape Toad" permite trabalhar com variáveis relativas. É o que temos aqui, são índices de densidades hab/ha. Possibilidades de visualizarmos o "peso" destes índices. A imagem final formada pela transformação cartográfica não é significativa. Não há sentido visual, nos falta referência inicial do "espaço dasimétrico". Por outro lado a grade [grid] resultante é significativa visualmente, inclusive, foi inspiradora e decisiva para representar, em modelização gráfica - capítulo 6 - as áreas de densidades populacionais.

$\mathrm{Na}$ figura 22 temos o exemplo do que denominamos de cartograma em anamorfose - quando este fundo é possível de ser explorado [Fundo + Tema]. O fundo de mapa não é mais o euclidiano tradicional e sim a população residente na metrópole paulista em 2008. Este fundo foi processado no "ScapeToad" e adequado ao aplicativo Philcarto ${ }^{39}$ para elaboração do tema Emprego. Temos aqui a relação de duas substâncias, de dois temas a serem explorados, o fundo de mapa é a população residente em cada município em 2008 e o tema representado sobre este fundo é o emprego por setor econômico. Temos 3 relações: população - fundo de mapa, porcentagem do setor no total de emprego e o número absoluto de quantidade de mão de obra empregada em cada setor. A métrica é a população por município e sua "escala cartográfica" pode ser aferida pelo número de habitantes por município da metrópole. Forma uma imagem alternativa do urbano - no caso a metrópole. Revela o "peso" de seus habitantes e relaciona-os com quais setores econômicos que mais propiciam empregos aos seus habitantes.

\footnotetext{
${ }^{39}$ Programa de cartografia livre disponibilizado pelo prof. Philipe Waniez em: http://philcarto.free.fr/
} 
Anamorfose do Mapa Dasimétrico da Densidade Urbana da Região Metropolitana de São Paulo

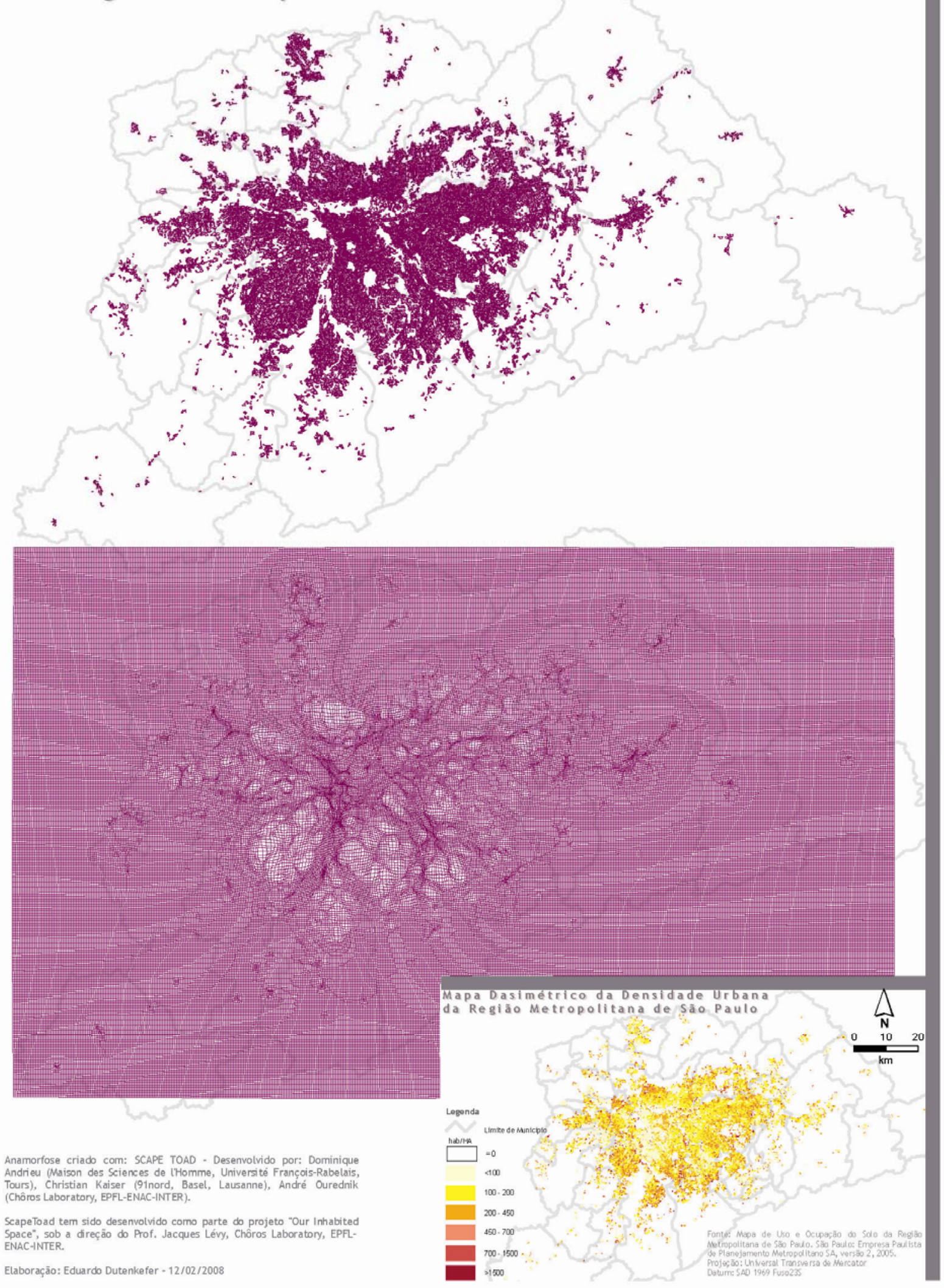

Mapa 16 - mapa em anamorfose do dasimétrico da metrópole de São Paulo 
Anamorfose do Mapa

Dasimétrico da Densidade Urbana do Municipio de

\section{Os asco}
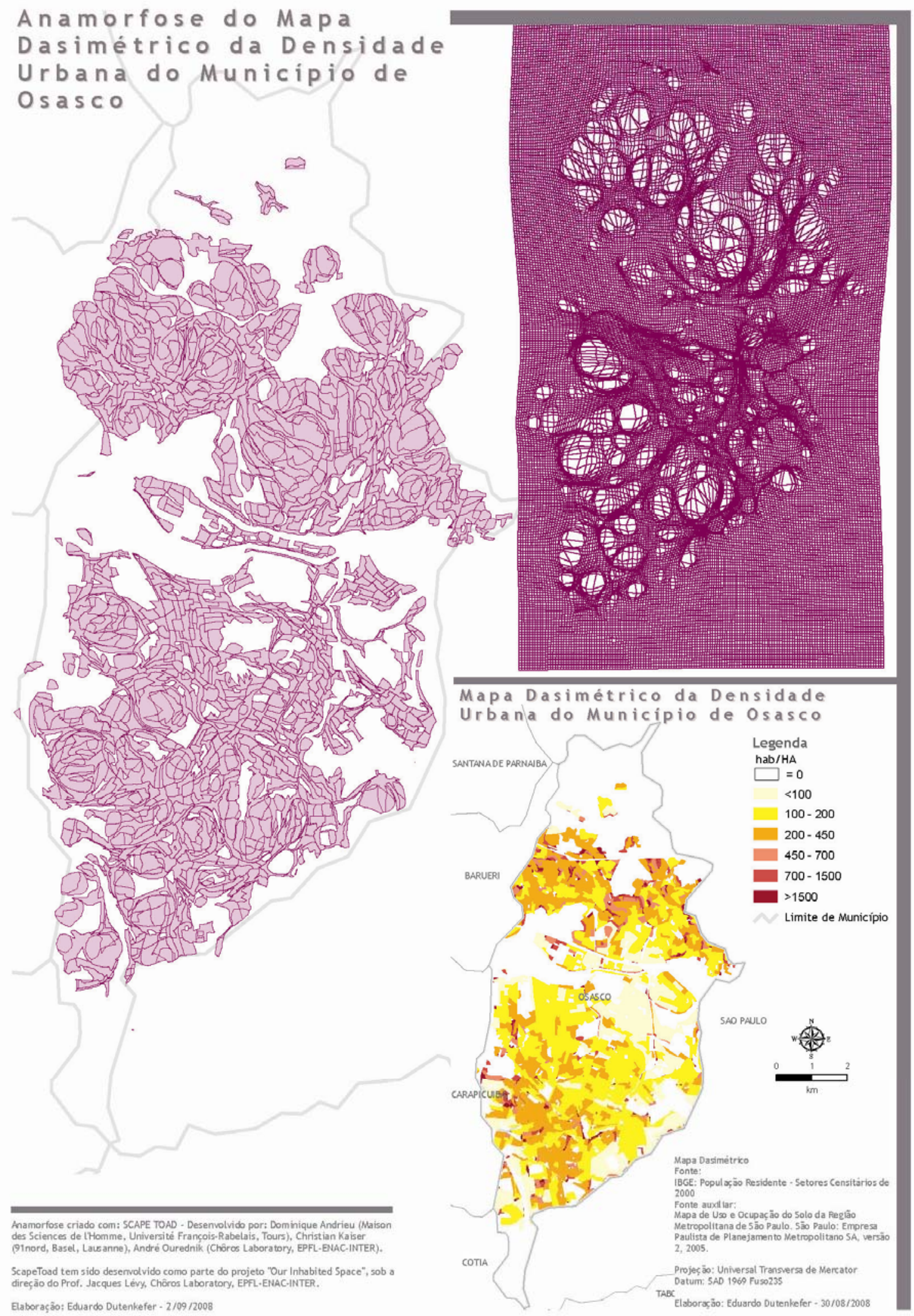

Mapa 17 - mapa em anamorfose do dasimétrico do município de Osasco 
Cartograma em anamorfose - Emprego - 2008
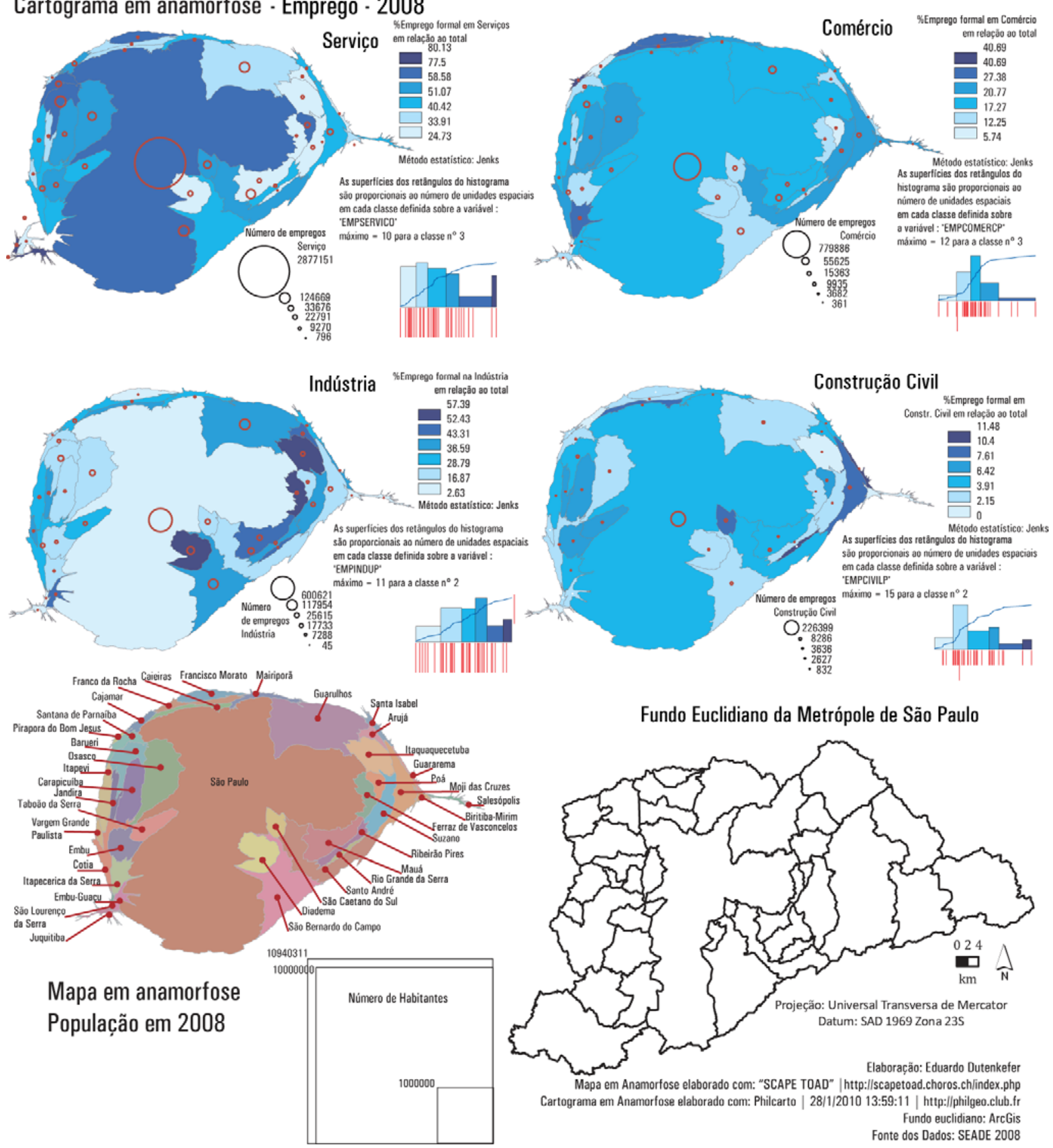

Figura 22 - Cartogramas em anamorfose 
Fazendo uma síntese de nosso método de análise para o mapa em anamorfose e cartogramas em anamorfose apenas para a metrópole de são Paulo temos:

\begin{tabular}{|c|c|c|}
\hline EIXO/MÉTODO & $\begin{array}{l}\text { MAPA } 13 \\
\text { mapa em anamorfose } \\
\text { da metrópole de São Paulo }\end{array}$ & $\begin{array}{l}\text { MAPAS da fig. } 22 \\
\text { cartogramas em anamorfose } \\
\text { da metrópole de São Paulo }\end{array}$ \\
\hline 1/1 - Espaço de referência & metrópole de São Paulo & metrópole de São Paulo \\
\hline 1/2 - Escala(s) cartográficas? & $\begin{array}{l}\text { Sem escala no sentido euclidiano. Medida } \\
\text { em números proporcionais ao número de } \\
\text { habitantes para o fundo de mapa. }\end{array}$ & $\begin{array}{l}\text { Sem escala no sentido euclidiano. Medida em } \\
\text { números proporcionais ao número de habitantes } \\
\text { para o fundo de mapa. }\end{array}$ \\
\hline $\begin{array}{l}\text { 1/3 - Princípio que norteou a } \\
\text { transposição analógica do } \\
\text { espaço referente para o espaço } \\
\text { no mapa. }\end{array}$ & $\begin{array}{l}\text { Número de habitantes. Localizantes } \\
\text { espaciais em função de [Z] }\end{array}$ & $\begin{array}{l}\text { Número de habitantes. Localizantes espaciais em } \\
\text { função de [Z] }\end{array}$ \\
\hline 1/4 - Métrica(s) utilizada(s) & número de habitantes & número de habitantes \\
\hline $\begin{array}{l}\text { 1/5 - "Temas", qual ou quais } \\
\text { substâncias contempladas? }\end{array}$ & $\begin{array}{l}\text { Homens, mulheres, crianças. [população } \\
\text { residente] }\end{array}$ & $\begin{array}{l}\text { Homens, mulheres, crianças. [população residente] } \\
\text { Emprego em serviços, comércio, indústria e } \\
\text { construção civil. }\end{array}$ \\
\hline $\begin{array}{l}\text { 1/6 - Semiologia de representação } \\
\text { gráfica empregada } \\
\text { [T4 - transformação semiótica] }\end{array}$ & $\begin{array}{l}\text { modo de implantação: zonal } \\
\text { quantitativa: forma do espaço referente } \\
\text { proporcional ao número de habitantes. }\end{array}$ & $\begin{array}{l}\text { modo de implantação: zonal; } \\
\text { quantitativa: forma do espaço referente } \\
\text { proporcional ao número de habitantes; } \\
\text { Quantitativa relativa: Porcentagem de emprego } \\
\text { formal em serviços, comércio, indústria e } \\
\text { construção civil, em relação ao total; [coroplético]; } \\
\text { Círculos proporcionais: Número de empregos. }\end{array}$ \\
\hline 2 - Transformação cartográfica & $\begin{array}{l}\text { Transformação cartográfica espacial de } \\
\text { posição temática de peso: } \\
X=f[Z] \text { e } Y=g[Z]\end{array}$ & $\begin{array}{l}\text { Transformação cartográfica espacial de posição } \\
\text { temática de peso: } \\
X=f[Z] \text { e } Y=g[Z]\end{array}$ \\
\hline 3 - Tipo de mapa & $\begin{array}{l}\text { "À leitura espacial"; } \\
\text { Fundo significativo => expressa densidade } \\
\text { fundo de mapa = tema }\end{array}$ & $\begin{array}{l}\text { "À leitura espacial"; } \\
\text { Fundo significativo => expressa densidade } \\
\text { fundo de mapa + tema => estabelece } 3 \text { relações: } \\
\text { população, porcentagem de emprego e emprego } \\
\text { total por setor econômico. }\end{array}$ \\
\hline
\end{tabular}

Quadro 2 - Quadro comparativo dos critérios de avaliação para o mapa e os cartogramas em anamorfose

Os mapas em anamorfose e os cartogramas em anamorfose formam uma imagem "estranha" ao nosso olhar acostumado com o mapa euclidiano tradicional, que evidencia a extensão do território em detrimento da dimensão da sociedade. Com esta "cultura euclidiana" é recomendável, ao elaborarmos nossos mapas em anamorfose, referenciá-los a uma imagem de fundo euclidiano. É o preço que pagamos pela nossa "traição à verdade" quando alteramos profundamente as representações do espaço geográfico. O mapa em anamorfose foca o nosso olhar em imagens de densidades. Nos exemplos apresentados, os programas em computador processam, no numerador desta relação, a "massa" de uma substância que escolhemos e, no denominador, ainda é a extensão tradicional de origem euclidiana. Mas o resultado final é a transformação da forma como representamos o espaço geográfico. 


\section{0 - Modelização Gráfica da metrópole de São Paulo}

\section{1 - Introdução}

A modelização gráfica é a "escrita de modelos geográficos sob a forma de figuras" (GRATALOUP, 2003, p.629, tradução nossa). Modelo, por sua vez, é a representação formalizada do real ou de um sistema de relações; em latim modellus "comporta a idéia de medida. Imagem da realidade, o modelo é uma construção que passa pela simplificação e pela abstração; pode ter por objetivos a ação, a previsão ou a explicação" (AURIAC, 1993, p.334 - tradução nossa).

A modelização é uma prática antiga na geografia, onde se procurava pôr em evidência os tipos de relevos, de cidades, de paisagens, etc, admitindo uma organização e a representação de suas formas elementares. Mas a idéia de modelizar as combinações das estruturas elementares recorrentes do espaço das sociedades é recente e foi proposta pelo geógrafo francês Roger Brunet (GRATALOUP, 2003, p. 629-630).

Brunet, em 1999, em palestra para a Societé de Geographie de Liège com o título de "Des modèles en géographie? Sens d'une recherche" [Modelos em geografia? Sentido de uma investigação], publicada em 2000, pondera:

O que é um modelo? Para defini-lo, os geógrafos recorrem a uma definição, que se tornou clássica de P. Haggett em 1965: "uma representação idealizada do mundo real, construída para demonstrar algumas das suas propriedades"; geralmente, infelizmente, esta fórmula é traduzida por "representação simplificada com o propósito de demonstração", o que representa um duplo e deplorável deslize. Modèle [Modelo], importado do italiano do século XV, vem de "moule": é uma figura que serve para reproduzir; a raiz é med, que encontra-se em medicina, meditar, etc., e que evoca a medida; tratase de "tomar a medida de", e idéia de modelo como sentido de avaliação e de ajustamento. Alain Rey define o modelo como "sistema que representa as estruturas essenciais de uma realidade"; observem que aqui é afastada a ideia de simplificação, mas não a ideia de essência, o que é diferentemente exigente (BRUNET, 2000, tradução nossa).

Brunet, em seu artigo publicado em 1980 na revista "L'Espace géographique" define a "estrutura elementar do espaço geográfico" de chorème [corema]. Chorème é um neologismo que se refere ao radical grego chor, que significa extensão, espaço, chôra, chôrê, pais, região e do sufixo -ême aos fonemas - unidades fonológicas de uma língua. Esta estrutura é representada por um modelo gráfico (BRUNET, 1987, p.190), (BRUNET et al., 1993, p.105), (BRUNET, 2001, 
p.196) e (GRATALOUP, 2003, p.154). Brunet ainda definiu que a Chorématique [Coremática] seria a "gramática dos Coremas; ciência (ou arte) do tratamento dos coremas e da interpretação das estruturas espaciais pelo reconhecimento e pela composição dos Coremas (BRUNET et al., 1993, p.105).

A abordagem coremática, portanto, é resultado de um conjunto de pesquisas e investigações desenvolvidas por Brunet desde os finais dos anos 60 e teve influencia da teoria dos sistemas, do estruturalismo, da semiologia gráfica de Bertin, da cartografia e da modelização gráfica. (BRUNET, 2000, 2007).

É em um artigo publicado em 1980, que propus os fundamentos de
uma abordagem "chorématique". Entretanto, tinha podido meditar
sobre as ciências humanas e notadamente nos trabalhos dos
estruturalistas, a começar por Lévi-Strauss cujo modelo de aldeias
correspondia exatamente no que tentava mostrar. A noção mesmo
de chorème é inspirada em parte pelas minhas leituras em linguística
e Sociologia. O chorème está para o espaço, assim como o fonema
está para a linguagem, como uma estrutura elementar que,
combinando-os, dá uma paisagem. (BRUNET, 2007, p.59-60,
tradução nossa)

A partir deste artigo a coremática foi desenvolvida e aplicada como instrumento de análise regional e de ordenamento/planejamento territorial a partir de um grupo de geógrafos reunidos em torno dos trabalhos do GIP-RECLUS (Groupement d'intérêt public - Réseau d'études des changements des localisations et unités spatiales), liderado por Brunet. Desse grupo surge a obra Géographie Universelle, em 10 volumes, publicada de 1990 a 1996. No primeiro volume "Mondes nouveaux," na primeira parte: "Le déchiffrement du monde" - Brunet expõe de forma mais elaborada a sua concepção de geografia. Uma versão derivada do primeiro volume é publicada em 2001 "Le déchiffrement du monde: théorie et pratique de la géographie" (BRUNET, 1990, 2001, 2007), (THÉRY, 2004).

Nesta obra, "Le déchiffrement du monde", Brunet coloca que as sociedades organizam - produzem - seu próprio espaço e que se reproduzem através do mesmo, por meio de um número de ações fundamentais, intencionais ou não. Estas ações, ou práticas sociais básicas, são classificadas em quatro: habitar, apropriar, explorar e trocar. Uma quinta - gerir/gestão - tem o papel de coordenar, governar, organizar as quatro básicas. Estas ações estão ligadas a quatro estruturas espaciais (figura 23): 
"maillage" [malhas] => conjunto de divisões territoriais definidas pelos sistemas de propriedade e gestão [estatal, público e privado];

"treillage" ou "quadrillage" [grelha, grade, treliça, rede, grid (inglês)] => rede de intercâmbio, circulação e comunicação;

"division spatiale du travail" ou "lieu de travail" =>divisão espacial do trabalho ou lugar de trabalho;

"habitat" => lugares de habitar, habitação, lar, moradia.

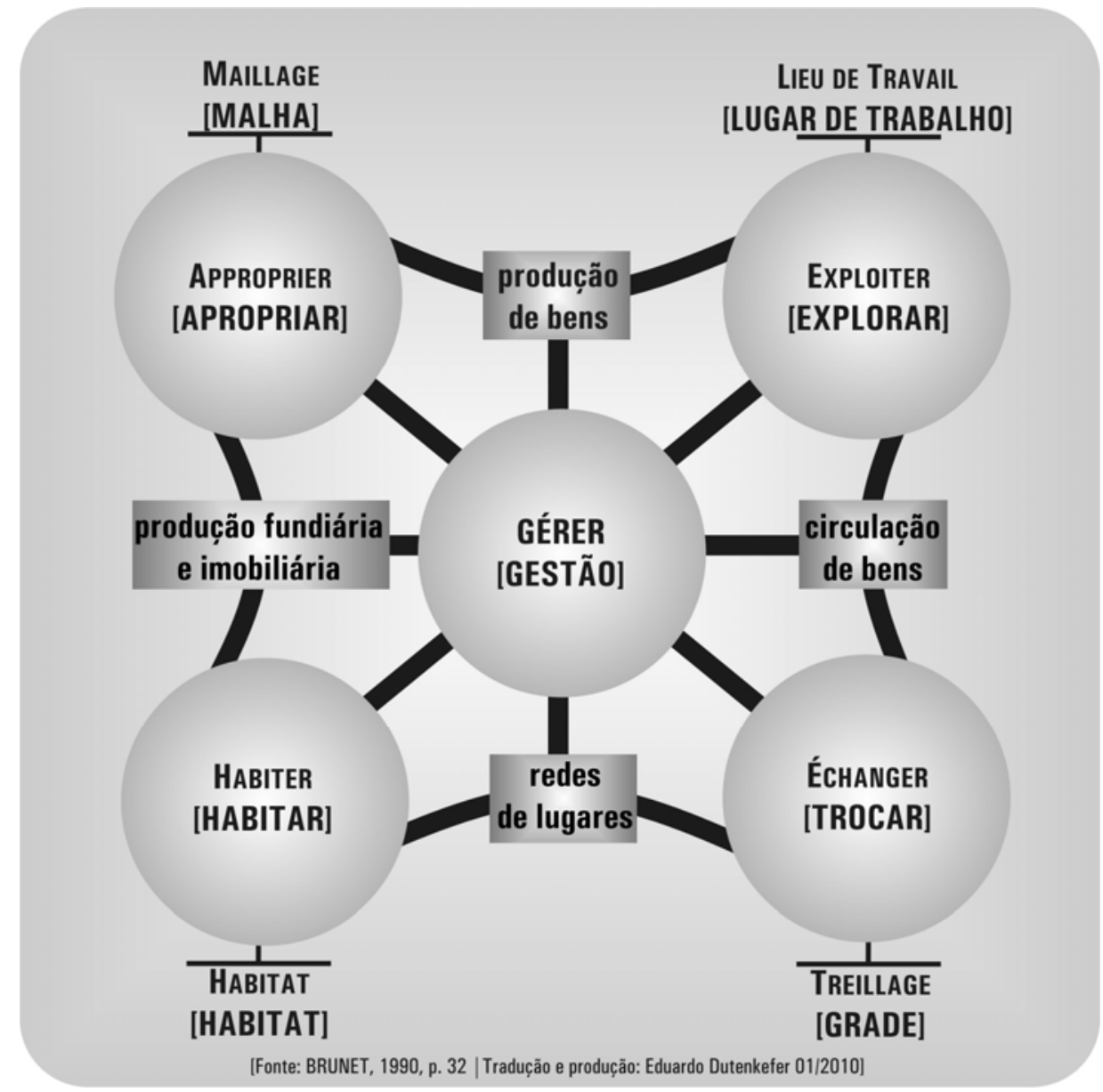

Figura 23 -Esquema de ações sociais e estruturas espaciais do espaço geográfico

As relações das ações com as estruturas espaciais estabelecem outras ações de importância geográfica: produção de bens, produção fundiária e imobiliária, redes de lugares e circulação de bens. "Toda ação de produção do espaço exercida sobre um terreno dado, um espaço prévio, torna-se um meio para uma nova ação" (BRUNET, 2001, p.139).

O espaço geográfico se organiza, têm as suas leis, as suas estruturas e as suas regras de transformação. Leis fundamentais do espaço geográfico são a distância e o espaçamento. Distância em 
relação aos centros e lugares de ação e espaçamento de pessoas e atividades. Estas leis fazem perceber princípios de uma relatividade geral do espaço geográfico, até em suas flutuações e transformações. (Brunet, 2001, p. 139, tradução nossa)

Para Brunet, estas ações ou práticas espaciais se desenvolvem de acordo com certas regras, modelos ou "leis". "Leis do espaço geográfico" quando se refere ao espaço organizado pelos homens e a "modelos de ação" quando têm uma lógica social. Brunet alerta que “'leis do espaço' só têm realidade quando expressam relações sociais, ou têm uma lógica social" (Brunet, 1990, p. 79).

A hipótese fundamental das leis do espaço é que se fundam sobre a
gravitação. Tudo ocorre "como se" Como se em todo lugar o espaço
geográfico exercesse sobre os outros uma atração em função direta
de sua massa e em função inversa de sua distância que os separa;
como se todo lugar experimentasse com relação aos outros uma
atração em função direta de sua massa e em função inversa de sua
distância; como se, entre dois lugares, a intensidade da interação
espacial são funções diretas de suas massas (mais exatamente, do
produto de suas massas) e função inversa de suas distâncias... De
uma forma geral e= M/d", onde $n$ é um coeficiente de "fricção" do
espaço, traduzido pelo fato de que a função da distância é percebida
geralmente e medida como uma exponencial (BRUNET, 2001, p.144
a 146, tradução nossa).

Em geografia a variável massa [M] pode expressar a magnitude de diversos indicadores: população, riqueza, renda, etc., e a distância, expressa como uma exponencial [função em matemática como exponencial, isto é não linear] sugere outras métricas além do metro, como a distância tempo, distância custo (BRUNET, 2001).

Para Brunet, o espaço geográfico está estruturado e diferenciado em diferentes níveis de complexidade. Suas estruturas podem ser apreendidas conceitualmente e representadas graficamente seguindo certas regras de modelização. Assim, qualquer espaço é a combinação de estruturas elementares os coremas - representados por modelos gráficos. Expressam ações, projetos e resultados. Expressam, enfim, lógicas sociais elementares de controle ou dominação do espaço. Brunet distingue e classifica estas lógicas em 7 [sete]: "maillage" e "trilagge" [malha e ligação/disposição] - indicam meios diretos dessa dominação e os 5 [cinco] restantes: gravitação, contato, tropismo, dinâmica territorial e hierarquia refletem efeitos particulares derivados dos anteriores. Combinando estas 7 lógicas e as quatro figuras geométricas, que representam graficamente a sua tradução espacial, teremos os 28 coremas de base, [quadro3] (BRUNET, 1990 e 2001). 


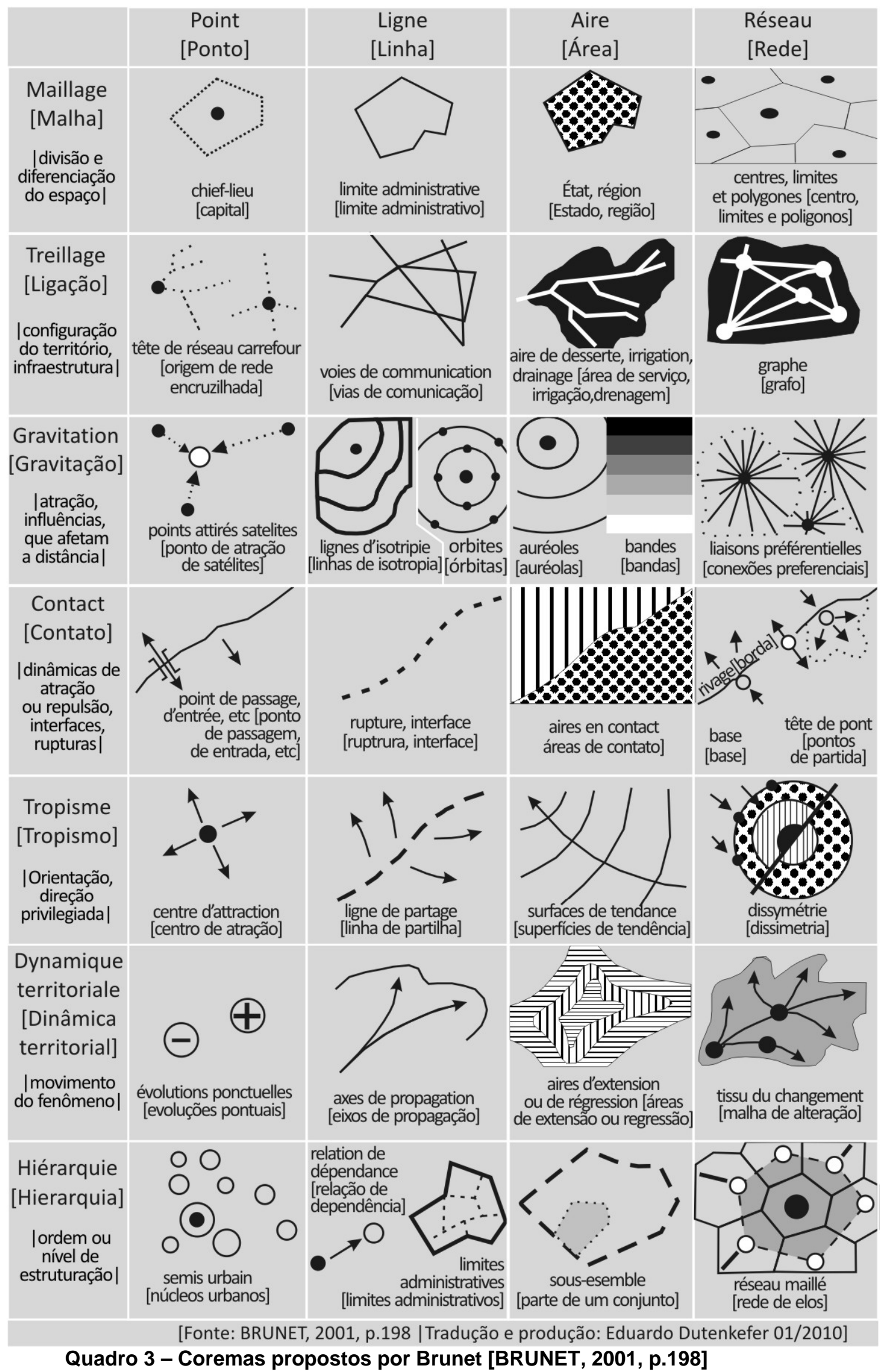


Em Brunet (1987, 1990 e 2001) temos as pistas de suas reflexões/sentidos/definições ${ }^{40}$ :

1. "Maillage" [Malha] se refere ao(s) sistema(s) de divisão e diferenciação do espaço. Maneira através da qual um território, uma área é dividida, subdividida. Atributos do território com objetivos de apropriação, exploração e/ou administração;

2. "Trillage" [Ligação] - [grelha, grade, treliça, rede, grid (inglês)] - [originalmente em BRUNET, 1990 era "quadrillage" [quadriculado]: representa a configuração do território, a sua infra-estrutura, o conjunto de redes de comunicação, circulação e outros [fluxos, por exemplo] do espaço. Ligações no território [interpretado neste trabalho como "ligação" no sentido de como está representado geometricamente a ligação, a disposição espacial da rede de infra estrutura];

3. "Gravitation" [Gravitação]: No sentido de atração, influências, que afetam a distância. Este corema pode expressar, por exemplo, distribuição e organização espacial do tipo central e periférico, hierarquias urbanas, centro(s) urbanos densos [de população, de equipamentos urbanos, etc.] ou rarefeitos, etc.

4. "Contact" [Contato]: representariam dinâmicas de atração ou repulsão, interfaces [campo-cidade, por exemplo] ou também de rupturas [terra-mar], descontinuidades;

5. "Tropisme" [Orientação] - [tropismo]: representam direções, orientações. Os fenômenos expressam a existência de orientações na organização do espaço de acordo com certas direções. São os gradientes, as dissimetrias, os fluxos dominantes em uma direção privilegiada.

\footnotetext{
${ }^{40}$ Foram utilizadas também as seguintes referências para tradução e interpretação dos termos:

ÁLVARES, Jacobo Garcia. La coremática y la nueva geografia regional francesa. Eria. Revista cuatrimestral de geografia, 45, 1998, p.8 e 9. disponível em: <http://www.revistaeria.es/index.php/eria/article/viewArticle/402> acesso: 13/01/2009.

GIRARDI, Eduardo Paulon. Proposição teórico-metodológica de uma cartografia geográfica crítica e sua aplicação no desenvolvimento do atlas da questão agrária brasileira. Tese (doutorado). Universidade Estadual Paulista, Faculdade de Ciências e Tecnologia, Presidente Prudente, 2008, p.74.

VAN ELZAKKER, Corné P. J. M. The use of maps in the exploration of geographic data. Netherlands Geographical Studies, 326, Utrecht / Enschede 2004, p. 69. Disponível em:

<www.itc.nl/library/Papers_2004/phd/vanelzakker.pdf.> Acesso: 09/01/2010

Dicionários e outros em linha:

CNRTL [Centre National de Ressources Textuelles et Lexicales] in : http://www.cnrtl.fr

http://translate.reference.com/

http://dictionnaire.sensagent.com/
} 
6. "Dynamique territoriale" [Dinâmica territorial]: representam os movimentos, fenômenos de expansão ou retração, de avanços ou retrocessos;

7. "Hiérarchie" [Hierarquia]: representa ordem ou nível de estruturação do espaço e, portanto, em diferentes subordinações (por exemplo, hierarquia das redes urbanas, funcionalidades).

Em um dos primeiros artigos no Brasil sobre modelização gráfica "Modelização Gráfica para a análise regional: um método", Hervé Théry apresenta a modelização gráfica como instrumento e como método de análise geográfica. Seus principais pressupostos incluem:

que cada lugar situa-se numa série de "campos" que estruturam o espaço, cuja interferência local forma um sistema; que cada situação define-se em relação a fluxos, por conseguinte em relação a centros, direções, limites;

que estas estruturas $e$ as suas combinações podem ser representadas por modelos. Estes, como nas ciências "duras" são simplificados, redutores provisórios, constituindo uma abordagem simplificada da complexidade, um instrumento que pode ser utilizado provisoriamente, até construir outro melhor;

que estes modelos podem ter uma expressão gráfica. A expressão gráfica tem sobre o discurso linear a superioridade de poder ser apreendida no espaço e, por conseguinte, de ser melhor adaptada para simbolizar a organização espacial, de ser mais sintética e ter neste domínio uma melhor eficácia demonstrativa;

O sucesso desse modelo é dar conta das localizações, das configurações espaciais observadas, de justificar, pelo jogo das interações, combinações e de algumas contingências locais, todas as irregularidades e deformações que aparecem;

A escala de trabalho é indiferente. É possível utilizá-lo tanto na escala do mundo como a dos quarteirões urbanos. [THÉRY, 2004 p. 179, 180 e 181]

Com estes pressupostos Théry formula sua modelização regional do Brasil em $1986^{41}$. Com seis modelos gráficos, este autor representa a síntese das estruturas essenciais que marcaram e marcam as oposições do território brasileiro (figura 24).

Com a realização de um exaustivo conjunto de mapas do território paulista a Fundação SEADE (Sistema Estadual de Análise de Dados) publica, em 2006, o seu "Atlas Seade da economia paulista" e como coroação final deste trabalho, Théry apresenta a sua modelização do território paulista (figuras 25 e 26).

\footnotetext{
${ }^{41}$ THÉRY, Hervé. Brésil / Brasil (un atlas chorématique). Fayard / Reclus, 1986. 88 p.
} 
O final do Atlas é o momento de questionar: "O que aprendemos com esses mapas? O que eles nos revelam sobre o território paulista? Quais são os pontos e eixos fortes do Estado, e as suas fraquezas? Algumas delas mostram formas semelhantes, será por casualidade ou terão alguma coisa em comum?". Ou seja, pode-se tentar neste momento uma abordagem que relacione os mapas do Atlas às estruturas profundas do território. Tal abordagem é a razão de ser da modelização gráfica...ficou conhecido como método coremático, porque se baseia nos coremas, elementos básicos da organização dos territórios, representados por modelos gráficos (THÉRY, 2006, p. 1).

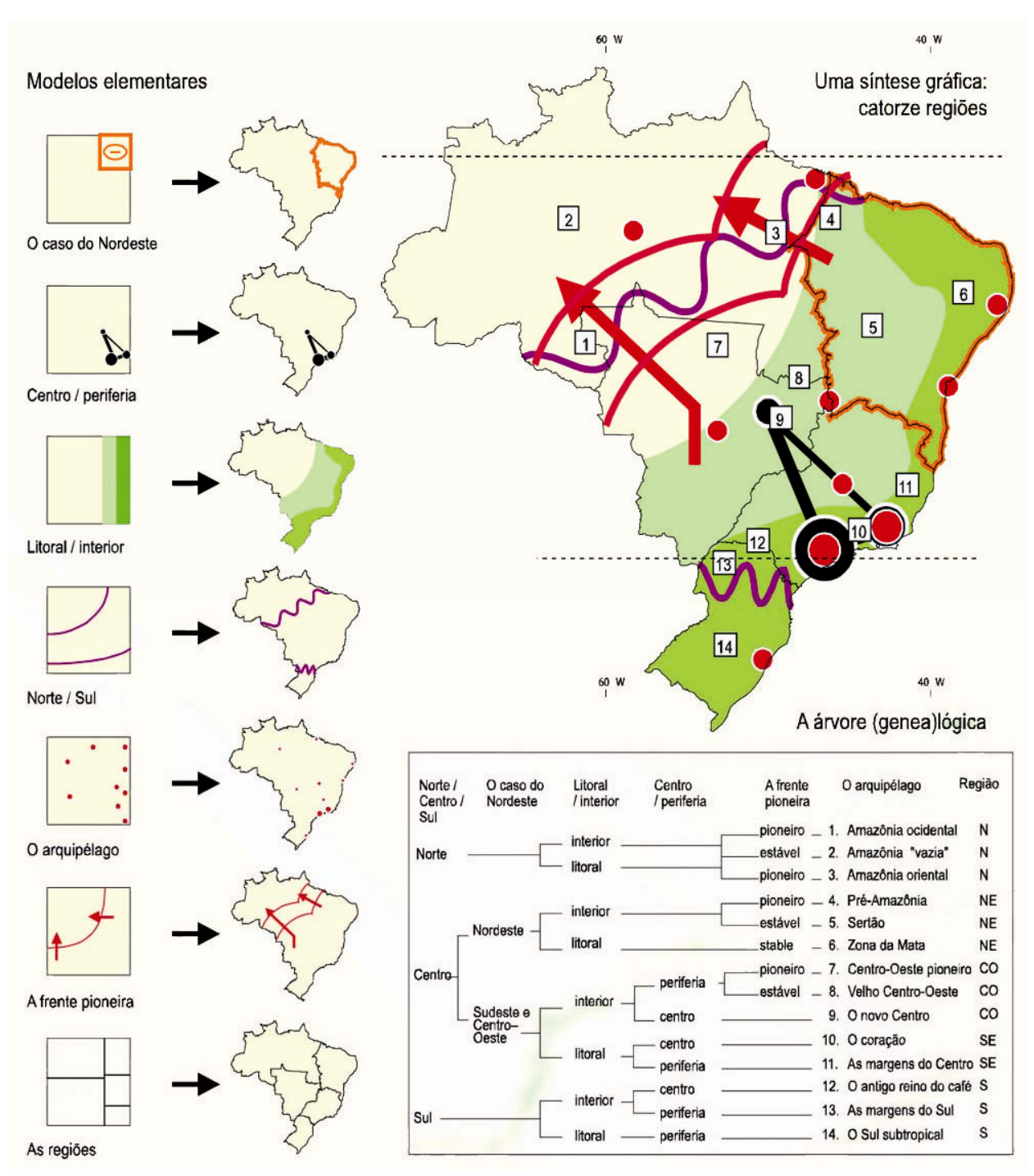

Figura 24 - Modelos elementares e síntese gráfica do território brasileiro

[THÉRY, 2006, p.2] 
Modelo teórico com imagem sintética do território paulista, baseado nos modelos elementares

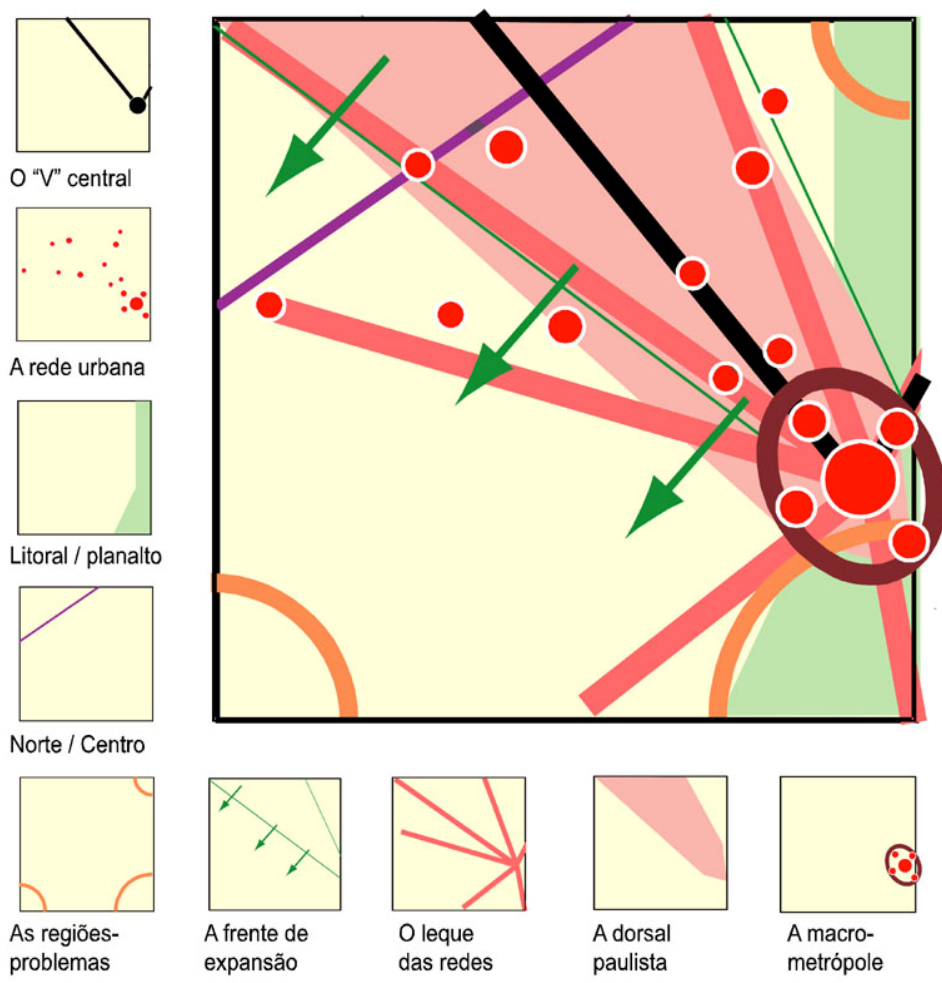

Figura 25 - Modelos elementares e síntese gráfica do território paulista [THÉRY, 2006, p.3]

Superposiçāo dos modelos elementares e novo modelo do território paulisto
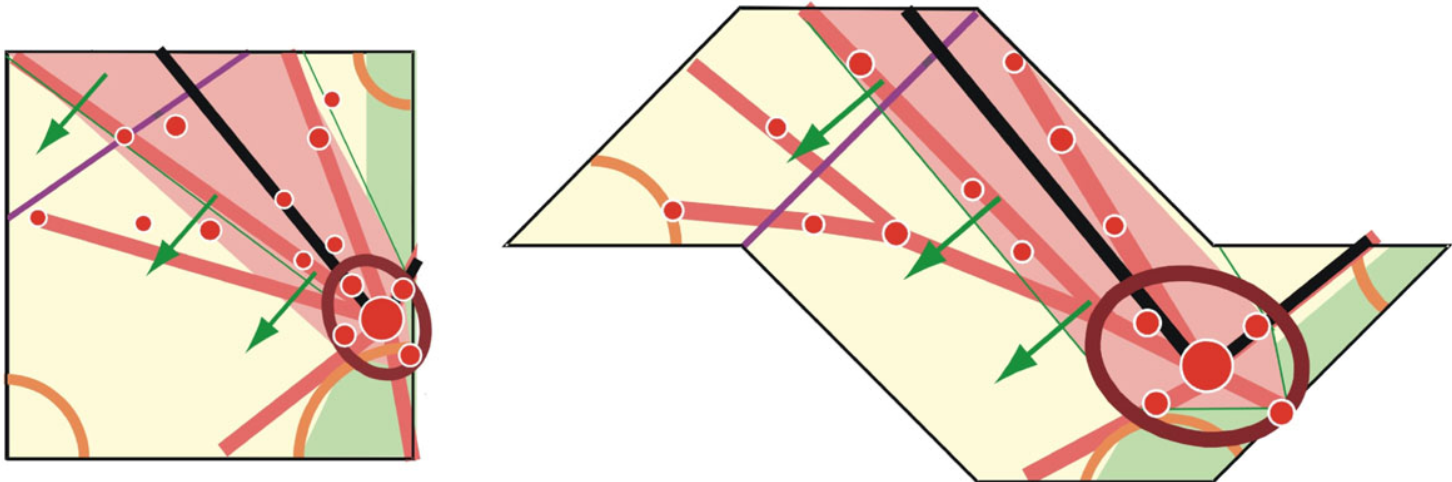

Figura 26 - Superposição do modelos elementares a um novo modelo do território paulista [THÉRY, 2006, p.3] 


\section{2 - A modelização da metrópole}

Um dos objetivos desta pesquisa é trabalhar a modelização gráfica para a metrópole de São Paulo. É obter como resultado uma expressão, uma síntese gráfica que represente, segundo o método da coremática, as principais ou, pelos menos, as mais expressivas estruturas e dinâmicas da metrópole paulista e em particular revelar as densidades urbana desta metrópole.

Este "modelizar o espaço geográfico" urbano da metrópole paulista partiu da investigação das estruturas e dinâmicas fundamentais por meio do "ver e/ou ler", da interpretação e análise dos diversos mapas que foram produzidos ao longo desta pesquisa. A questão que se levanta é que estruturas e que dinâmicas urbanas as representações dos mapas nos revelam? Correspondem a algum corema conhecido? A tabela dos 28 coremas de Brunet, considerada de forma aberta, orienta outras possibilidades de modelização.

O mapa, aqui, não é um elemento figurativo, ilustrativo, auxiliar que sintetizaria um longo texto analítico. É, antes de tudo, um instrumento de pesquisa que pode revelar as estruturas mais profundas de um território (THÉRY, 2006).

Elaboramos duas sínteses, a primeira a partir dos mapas do capítulo 4 dasimétricos, mapas da EMPLASA e da anamorfose do dasimétrico, do capítulo 5 mapa 16, pg. 990 - resultando em 11 modelos elementares. A segunda síntese foi feita a partir dos mapas em anamorfose e cartogramas em anamorfose do capítulo 5 e mais o mapa 18 da página 122.

Como a lógica da modelização e da representação coremática é geométrica e abstrata, a primeira tarefa a que nos propusemos foi eleger uma superfície de trabalho simples. Nossa solução foi geometrizar o fundo de mapa tradicional da metrópole paulista (figura 27). Como resultado final, encontramos um trapézio escaleno. Utilizando posteriormente o aplicativo "MapShaper"42 também obtivemos uma trapézio escaleno (figura 28). Nosso primeiro corema; "Maillage" - nosso recorte espacial baseado em limites administrativos/normativos.

\footnotetext{
${ }^{42}$ Aplicativo on line que por meio de 3 diferentes métodos, generaliza fundos de mapa digitais que estejam em formato shapefile. Disponível em: <http://mapshaper.org/>. Acesso: 20/02/2010.

[MapShaper is a free online editor for Polygon and Polyline Shapefiles. It has a Flash interface that runs in an ordinary web browser - The MapShaper project was conceived in 2005 by Matthew Bloch |http://maps.grammata.com/ - New York Times graphics editor| and Mark A. Harrower |Associate Professor of Geography, UW-Madison| |http://www.geography.wisc.edu/ harrower/| at the University of Wisconsin, Madison Geography Department - USA]. Detalhes do aplicativo no "paper" disponível em: http://maps.grammata.com/autocarto2006_paper.pdf
} 
Um fundo de mapa para a metrópole

O fundo euclidiano

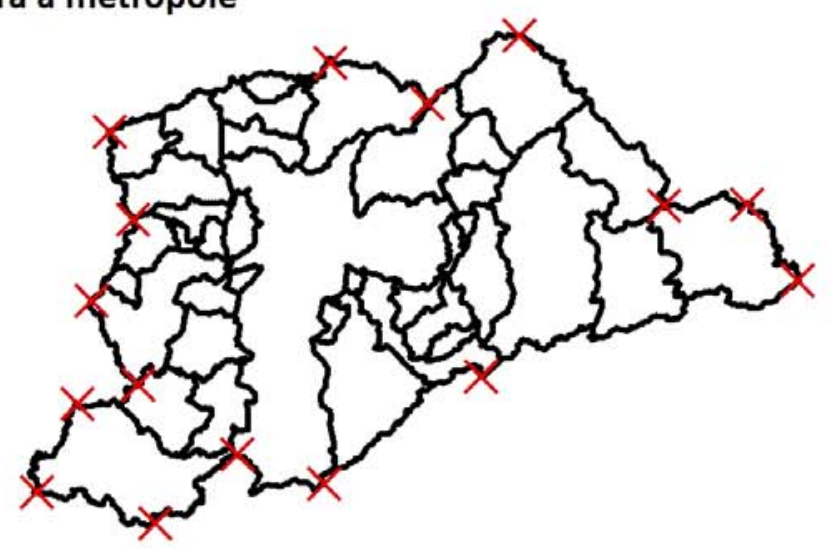

A simplificação
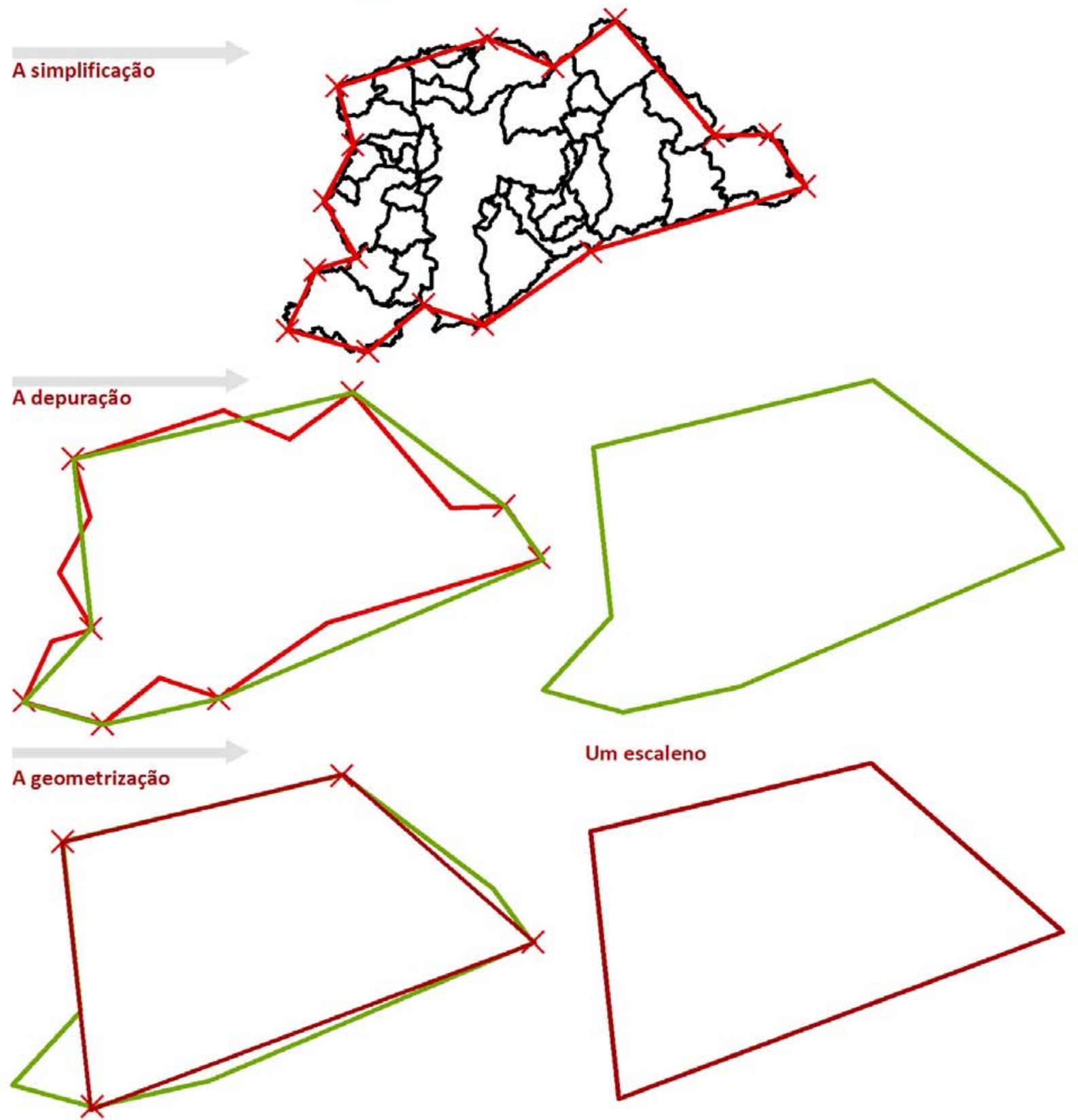

Figura 27 - "Geometrização" do fundo de mapa euclidiano da metrópole paulista 
Figura 28 - Sequência de generalização pelo aplicativo "MapShaper"

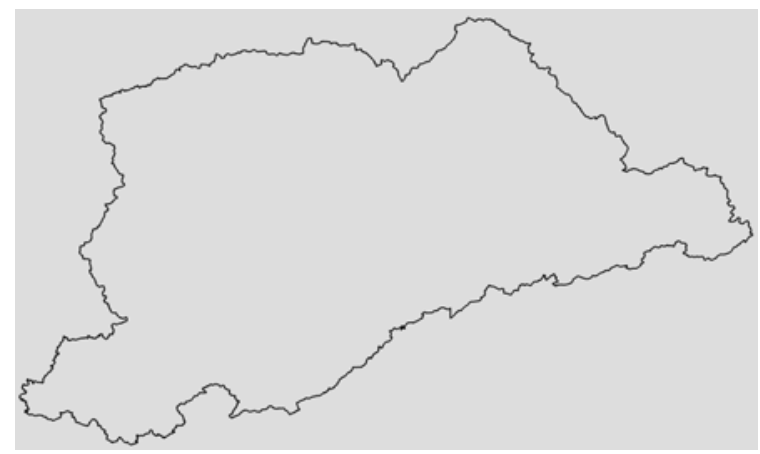

Fundo de mapa sem generalização

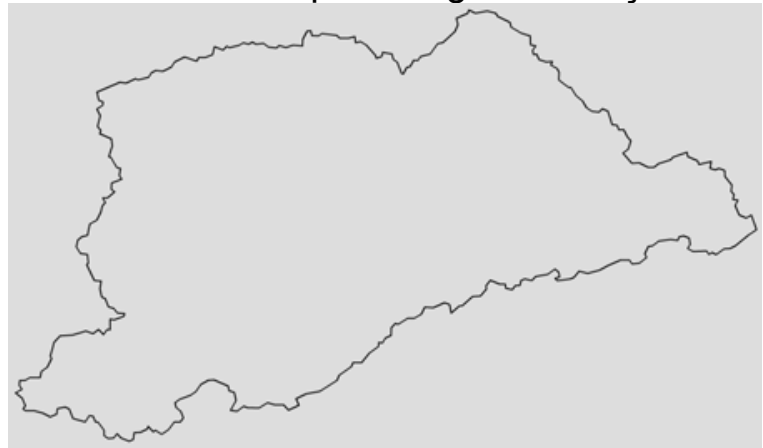

$50 \%$ de generalização

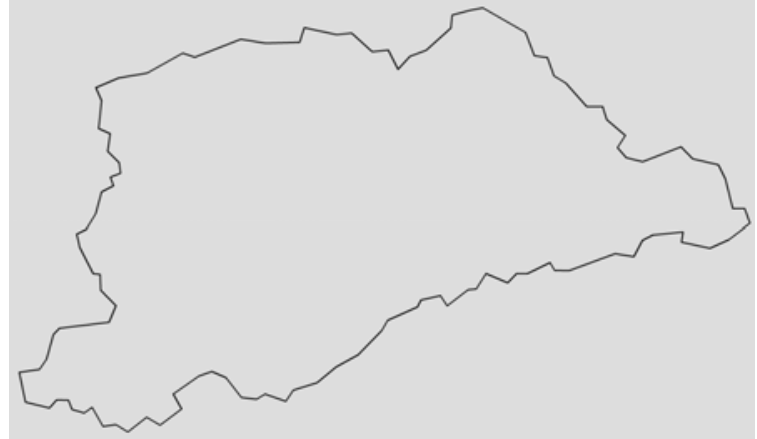

$80 \%$ de generalização

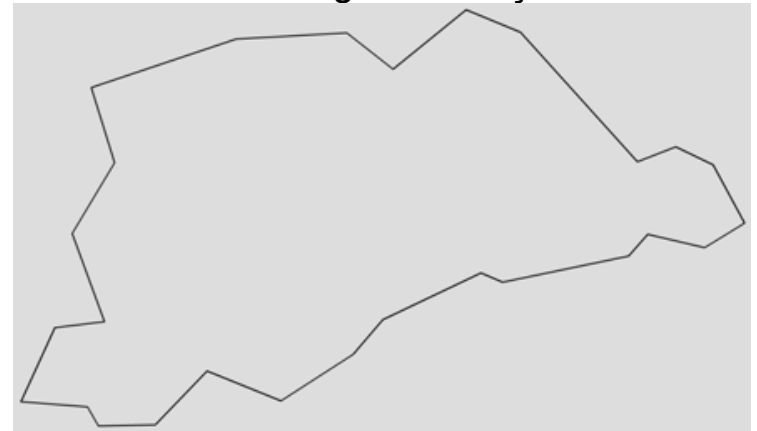

90\% de generalização 


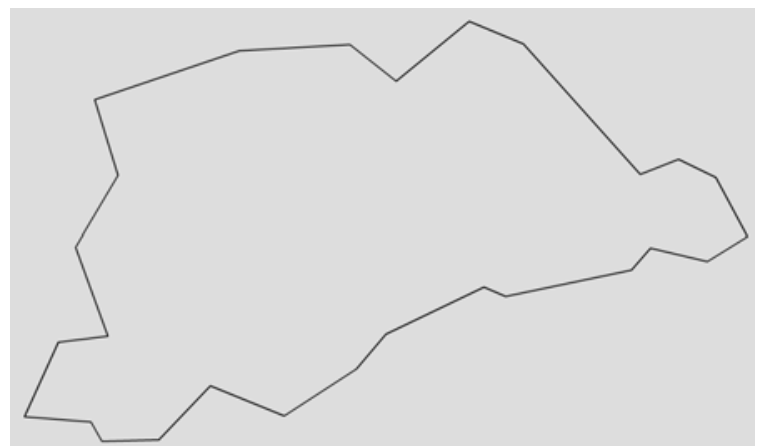

95\% de generalização

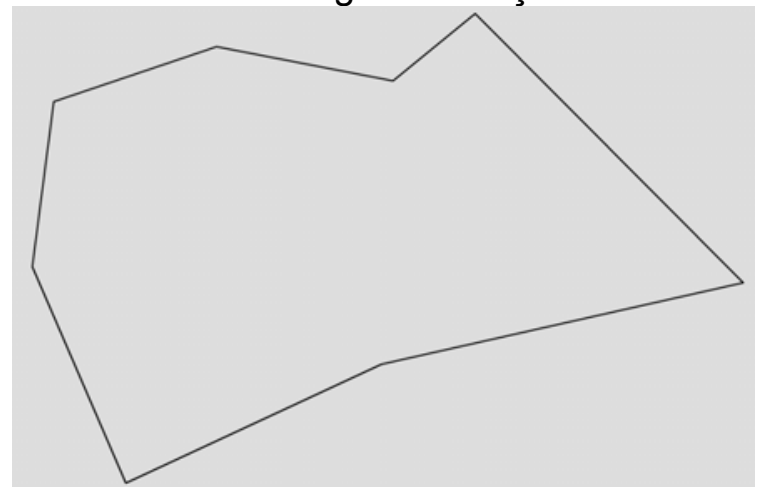

99\% de generalização

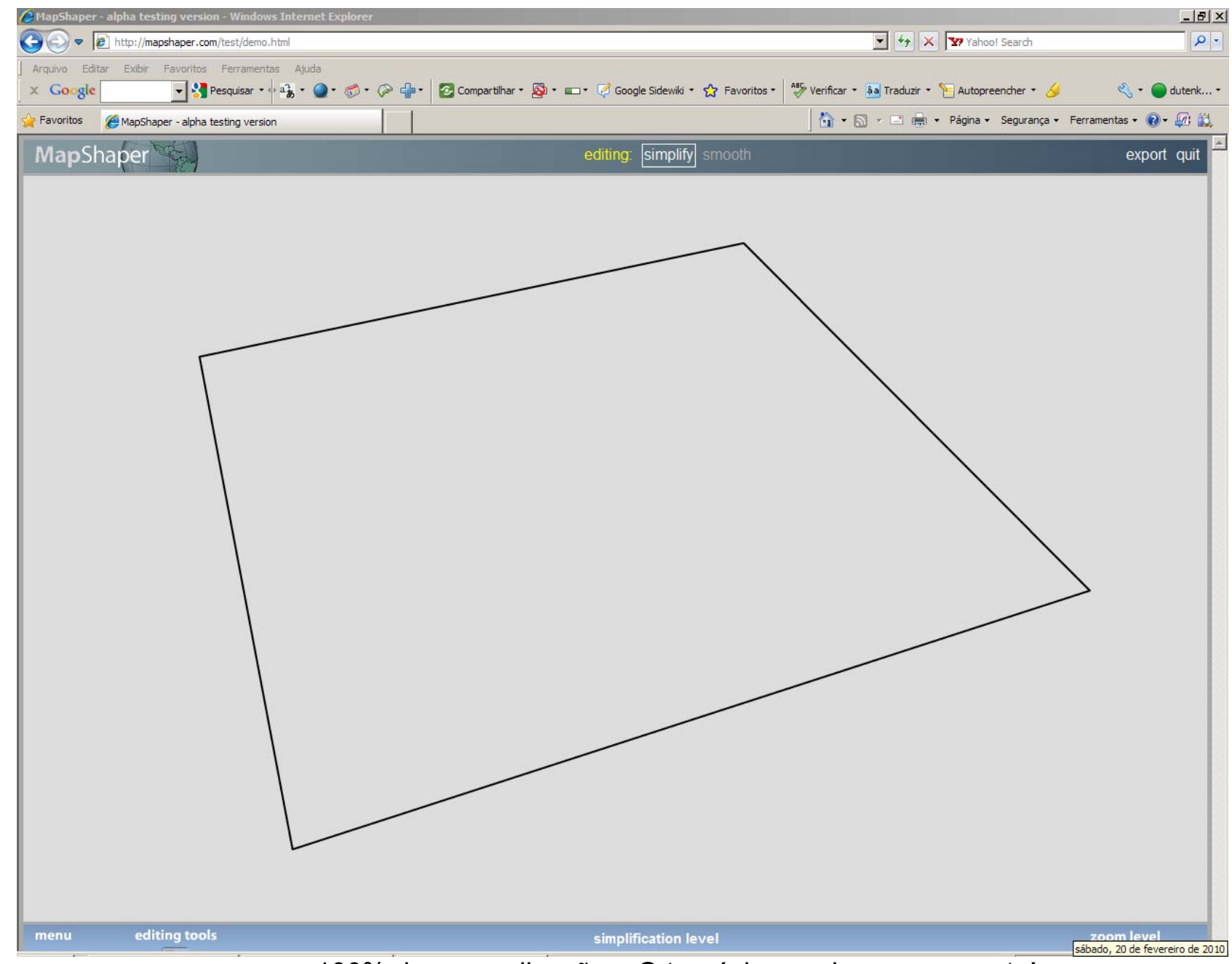

$100 \%$ de generalização - O trapézio escaleno novamente!

Figura 28 - Sequência de generalização pelo aplicativo "MapShaper" 


\subsection{1 - A primeira síntese: - Os modelos elementares}

Uma apreensão interna das principais estruturas da metrópole.

Figura 29 - Modelo elementar 1 - Nosso "Maillage" - O limite metropolitano

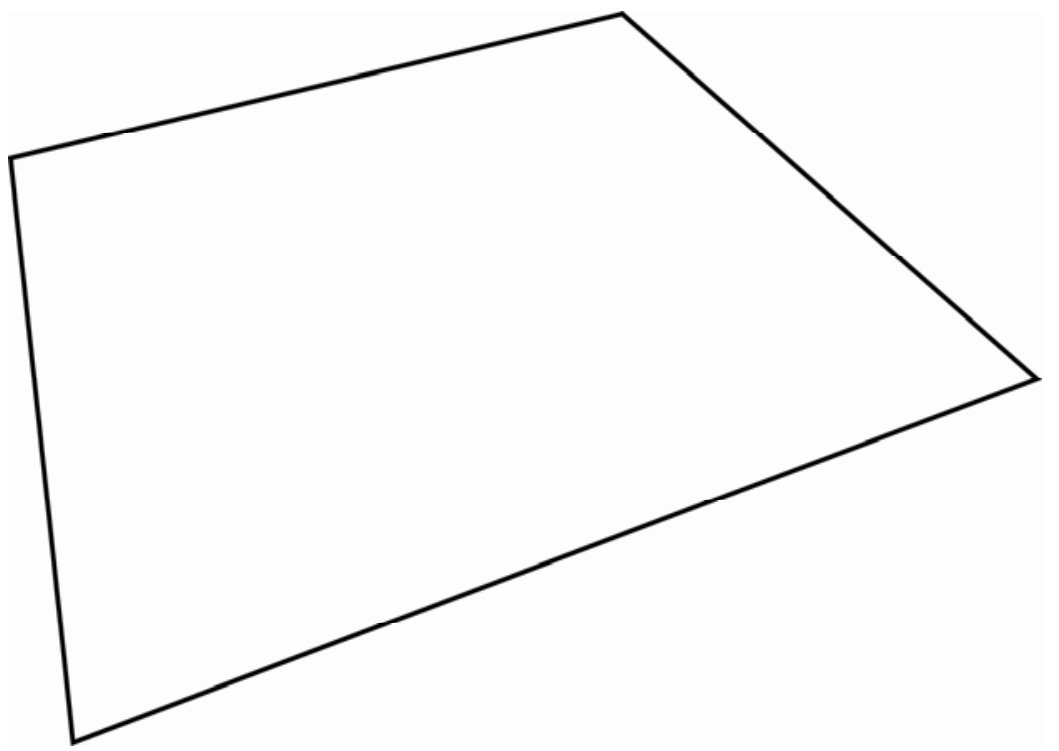

Figura 30 - Modelo elementar 2 - O centro histórico da metrópole

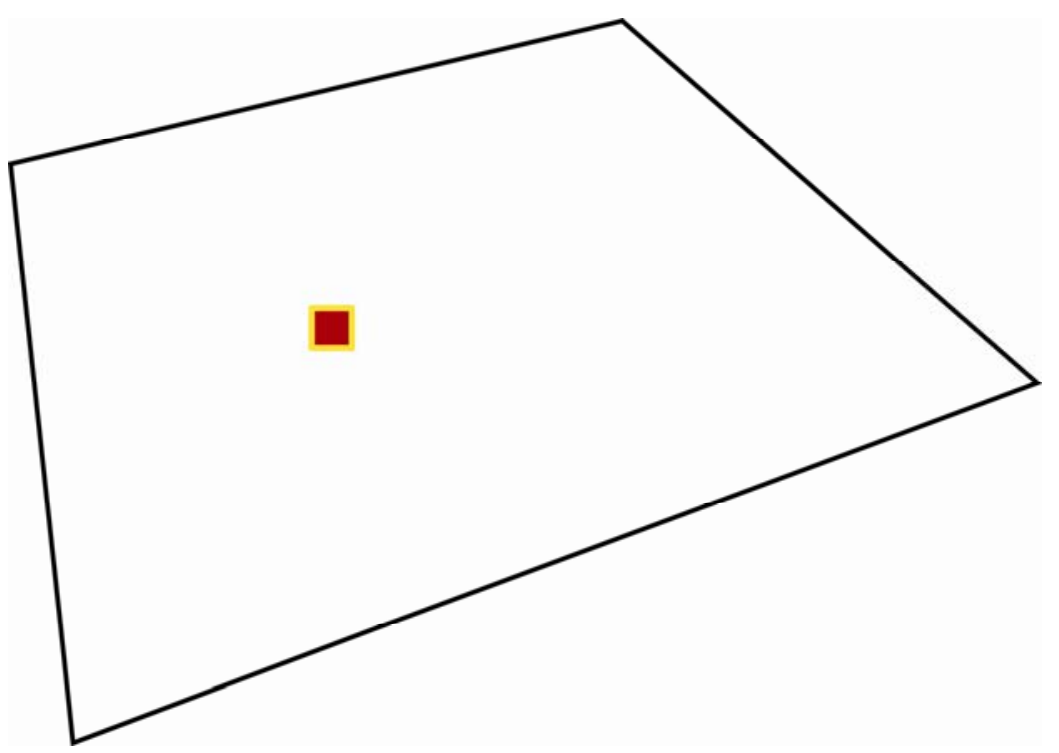


Figura 31 - Modelo elementar 3 - Treillage $=>$ a densidade de rede de comunicação

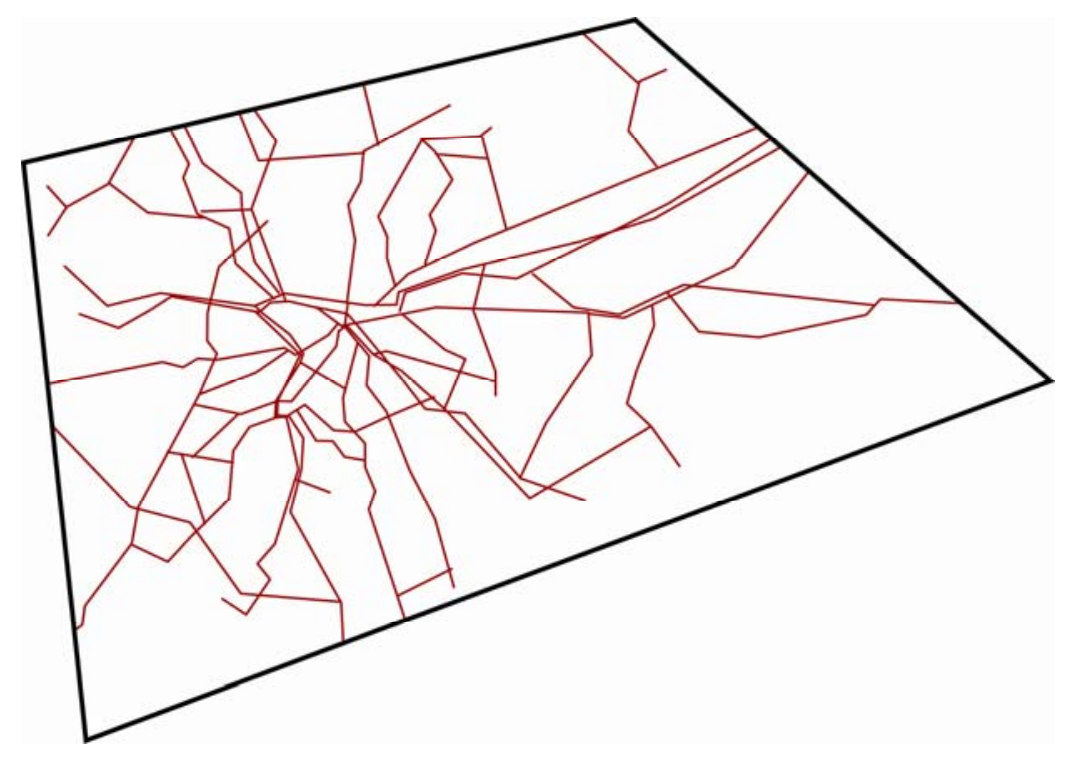

Figura 32 - Modelo elementar 4 - Área de serviço de água e drenagem

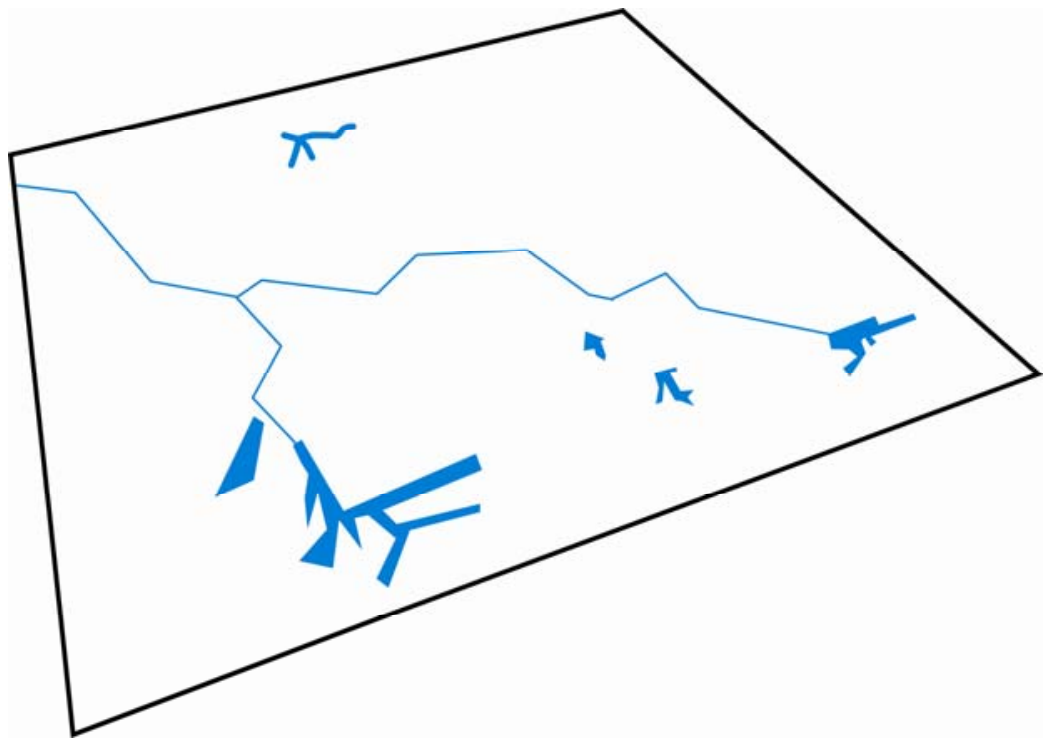


Figura 33 - Modelo elementar 5 - Áreas de indústria

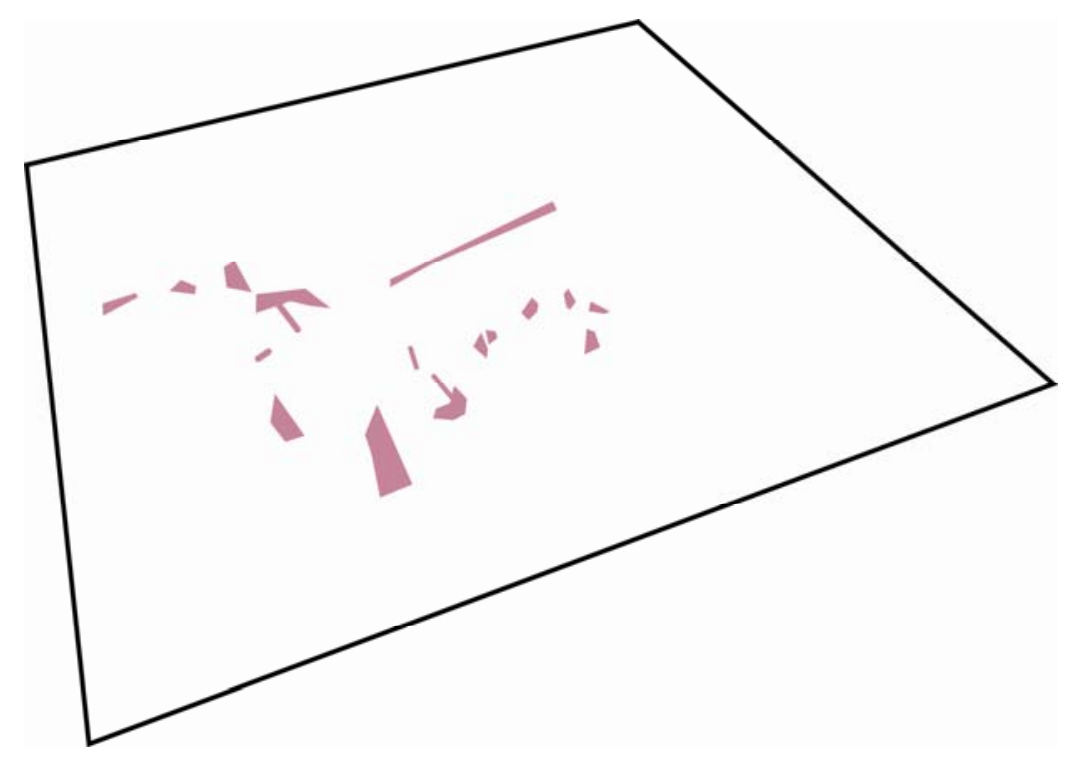

Figura 34 - Modelo elementar 6 - Centros de população residente - a densidade populacional

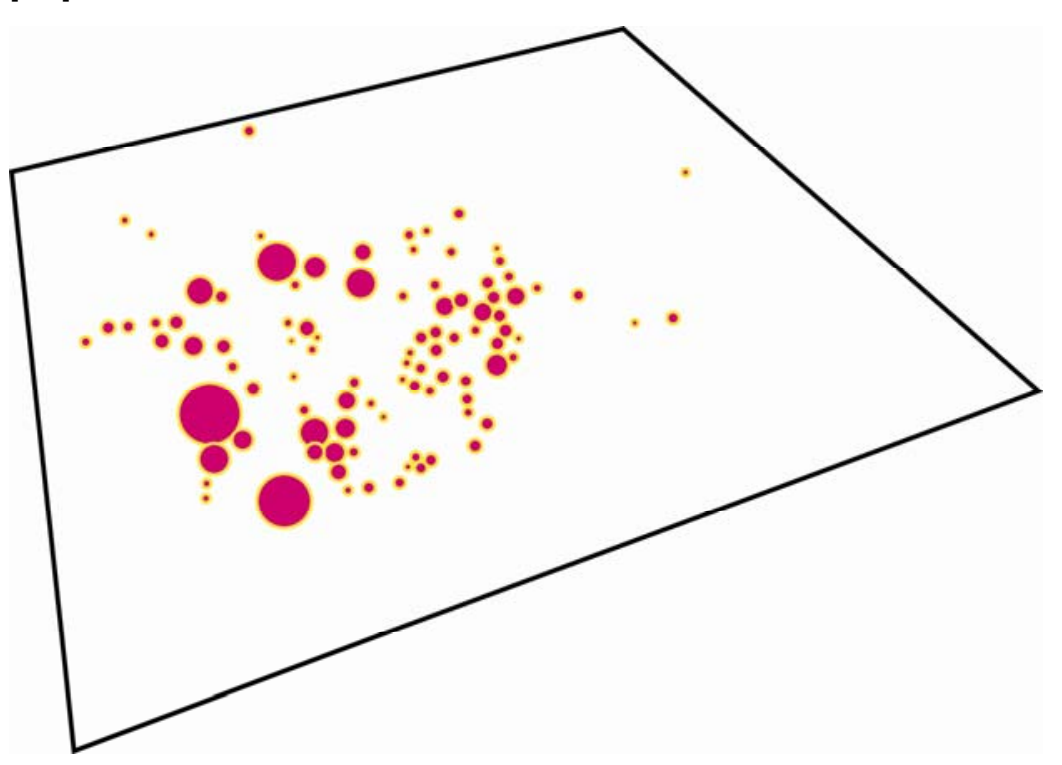


Figura 35 - Modelo elementar 7 - Densidade de equipamentos urbanos

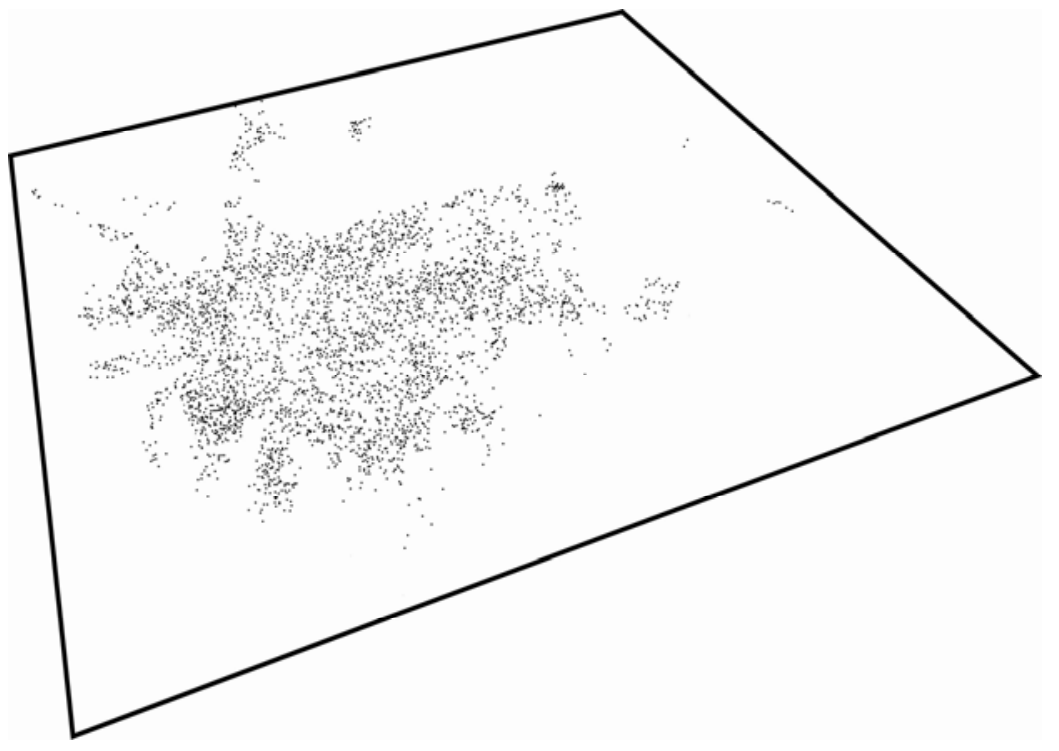

Figura 36 - Modelo elementar 8 - A extensão urbana

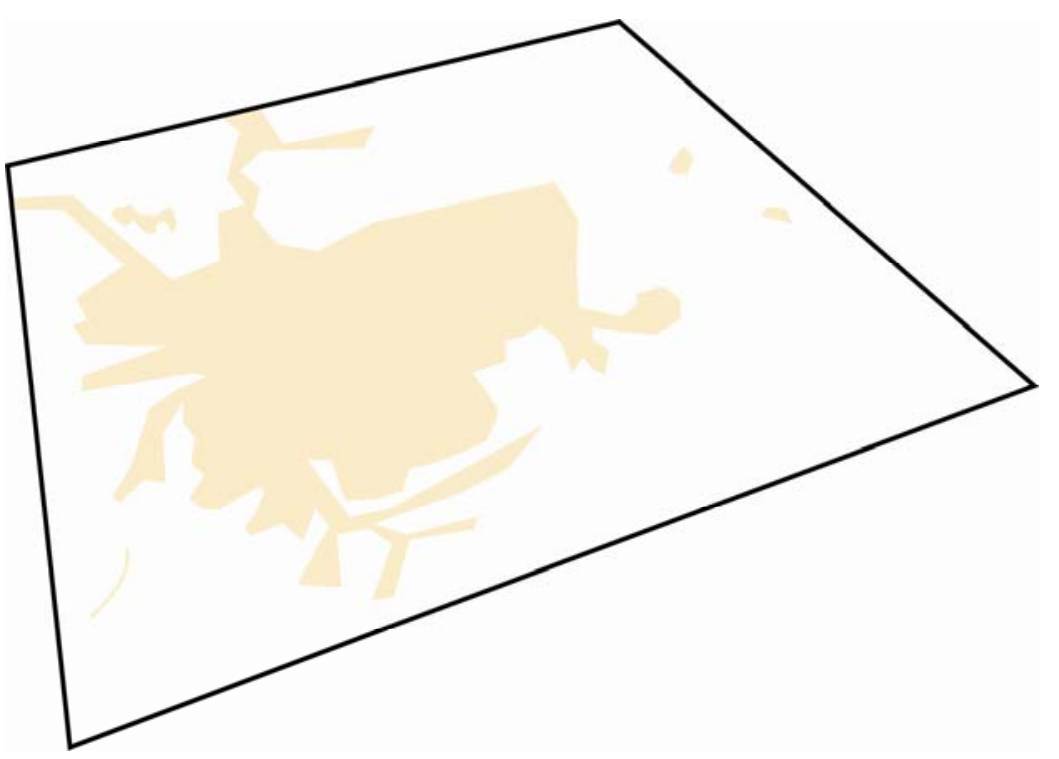


Figura 37 - Modelo elementar 9 - A extensão hortifrutigranngeiro

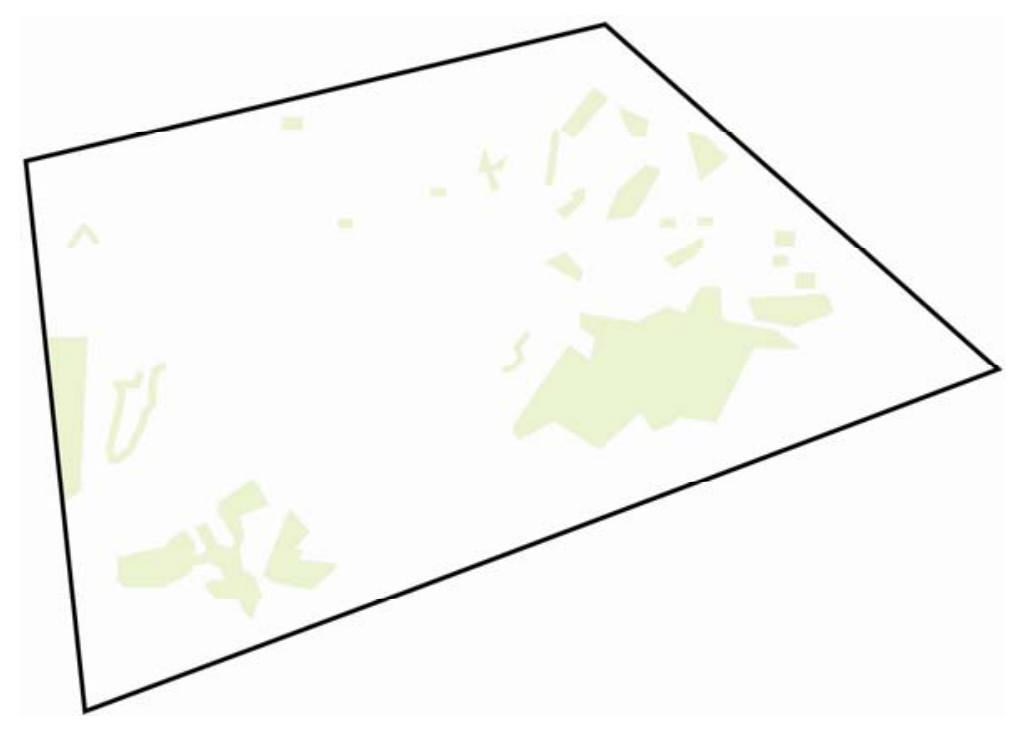

Figura 38 - Modelo elementar 10 - A extensão de chácaras para lazer/moradia

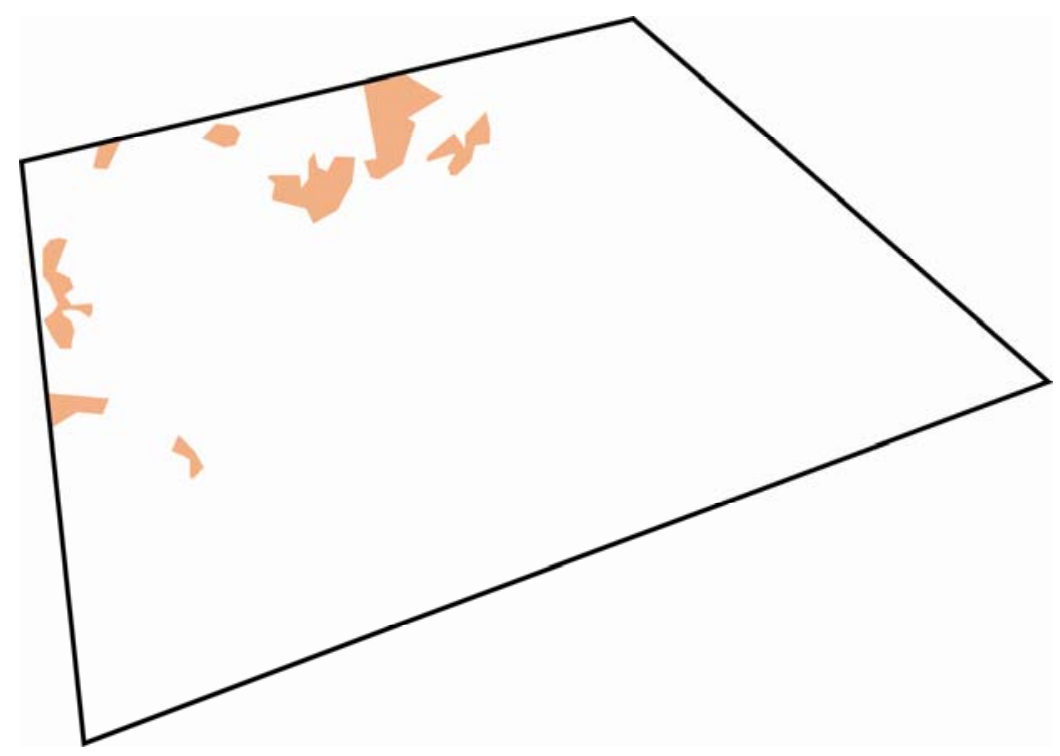

120 
Figura 39 - Modelo elementar 11 - A extensão da vegetação

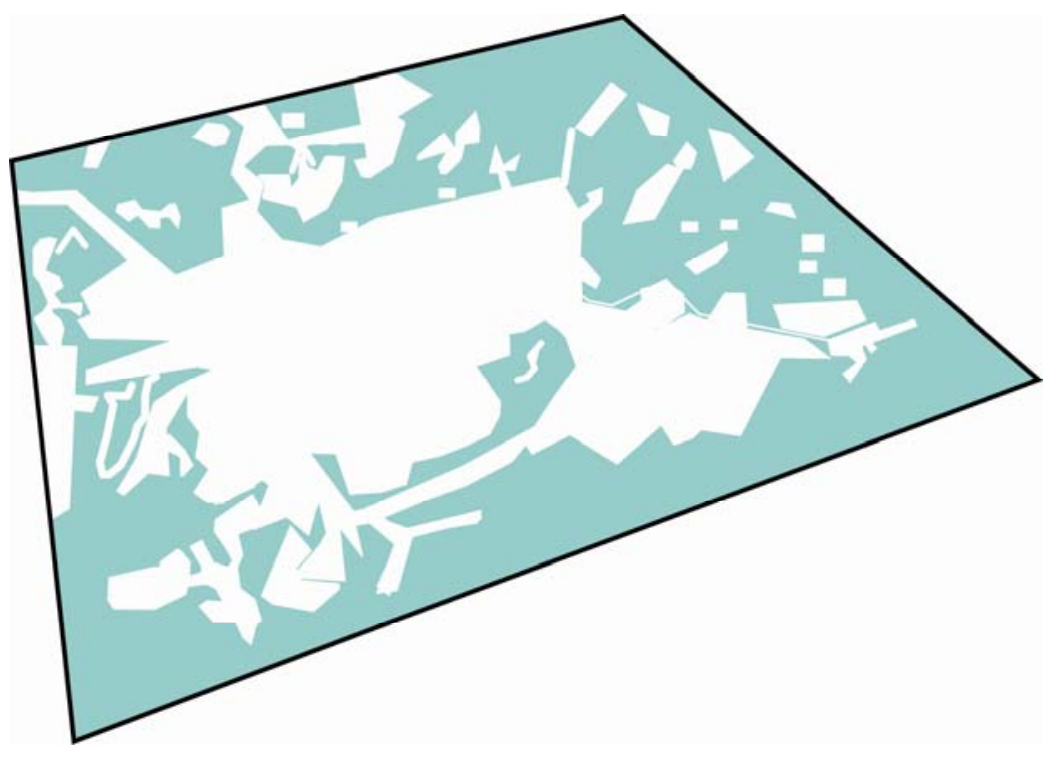

Figura 40 - A síntese 1- a modelização gráfica da metrópole

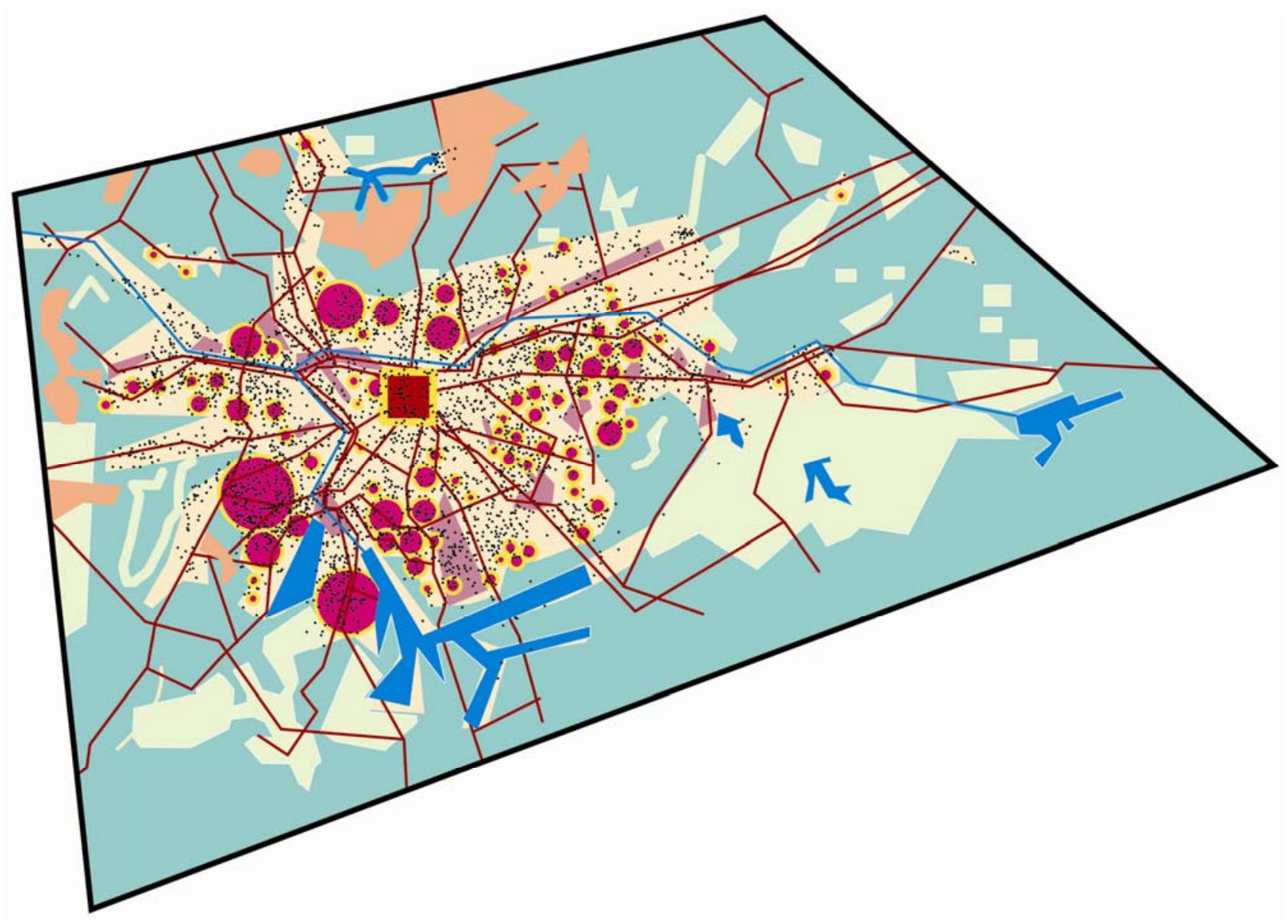


Mapa em anamorfose - PIB municipal 2000

Cartogramas anamorfose PIB municipal e IDHM 2000

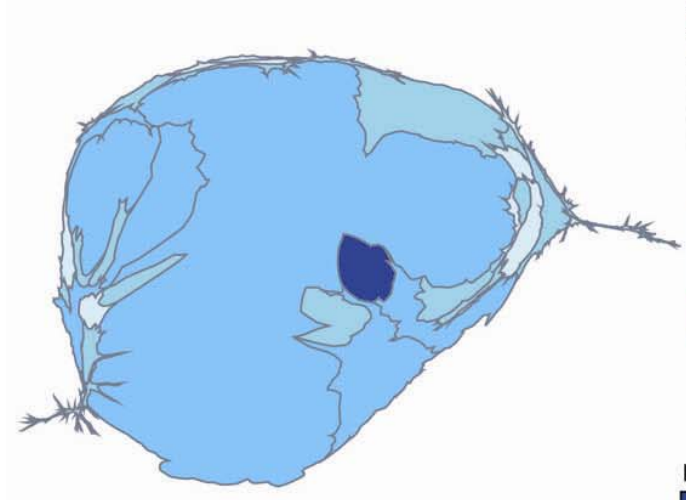

[Jenks] IDHMLON0O $\square=0.0039$ $\square, \mathrm{N}=16 \mathrm{M}=0,77 \mathrm{~S}=0,01$ $\square=0,75 \mathrm{~S}=0,0$

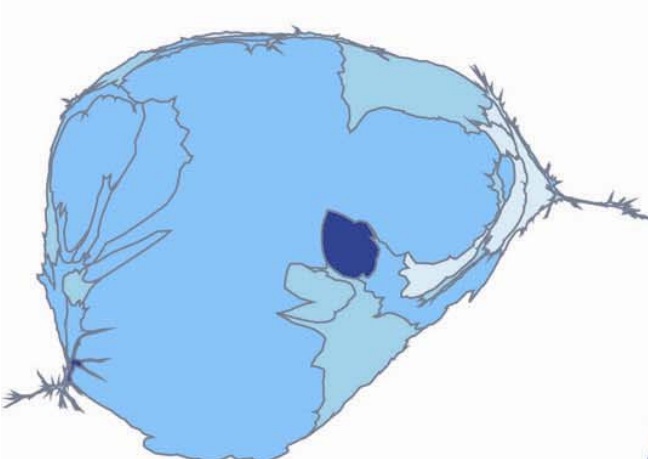

IDHMLLONOO
máximo $=16$ para a classe $n^{*} 3$
[Jenks] IDHM2000

$\square^{0.92} \mathrm{~N}=1 \mathrm{M}=0,92 \mathrm{~S}=0,00$

$\square=0,83 \mathrm{~S}=0.01$

$\square=0,0,0=0.01$

$\square_{0,74}^{0,78} \begin{aligned} & \mathrm{N}=14 \\ & \mathrm{M}=0,76 \mathrm{~S}=0,01\end{aligned}$

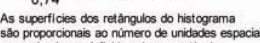

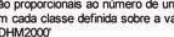

no $=17$ para a classe $n^{*} 2$

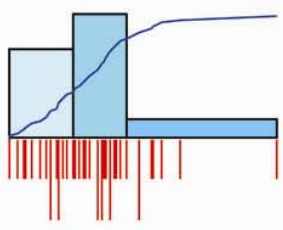

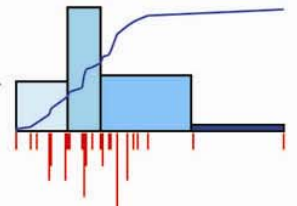

IDHM - renda

[Jenks] IDHMR2000

$\square=0,0,9003 \quad M=0,87 \mathrm{~S}=0,02$

$\square \mathrm{N}=7 \mathrm{M}=0,79 \mathrm{~S}=0,02$

$\square=0,0,17 \mathrm{M}=0,73 \mathrm{~S}=0,02$

$\square_{0,64}^{0,71}=12 \mathrm{M}=0,67 \mathrm{~s}=0,02$

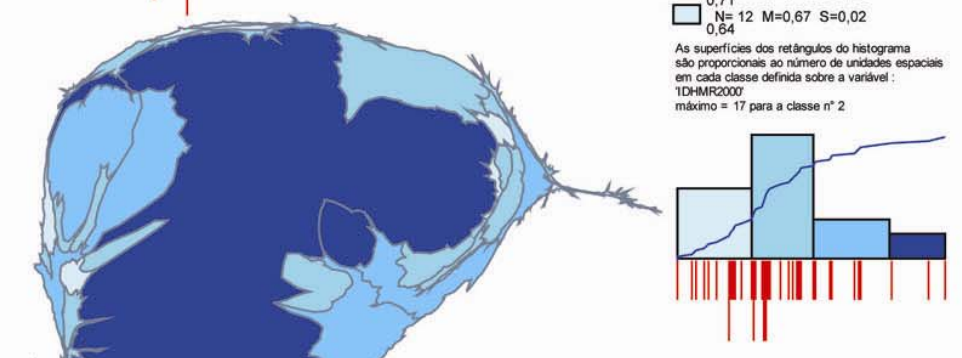

[Jenks] IDHMEDU0O

$\square \mathrm{N=3} M=0,95 \mathrm{~S}=0,02$

$\square=0,01 \mathrm{~S}=0,01$

$\mathrm{N}=15 \mathrm{M}=0,88 \mathrm{~S}=0,01$
0.86

$\square_{0,82}^{0,86} \mathrm{~N}=0.84 \mathrm{~S}=0,01$

IDHM - educação

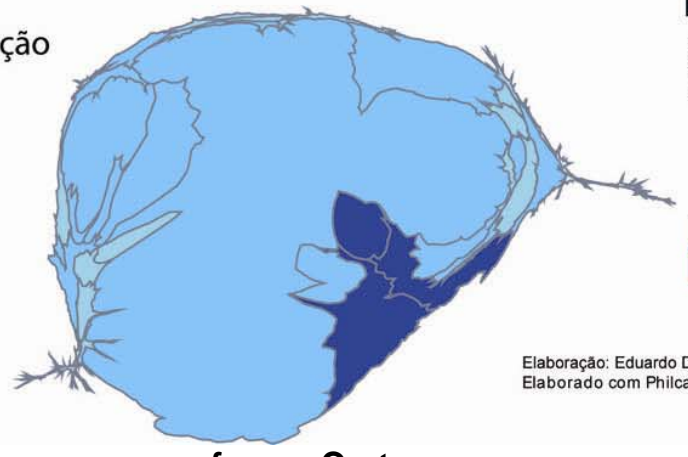

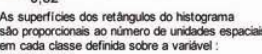
Em cada classe definida sobre a v
IDHMEDUOO iximo $=16$ para a classe $n^{*} 3$

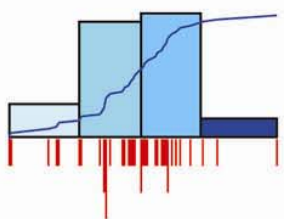

Eduardo Dutenkefer - geógrafo - 7/2010

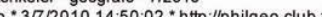

Mapa 18 - Mapa em anamorfose e Cartograma em anamorfose - PIB e IDHM 2000 
6.2.3 - A segunda síntese - baseado em anamorfoses:

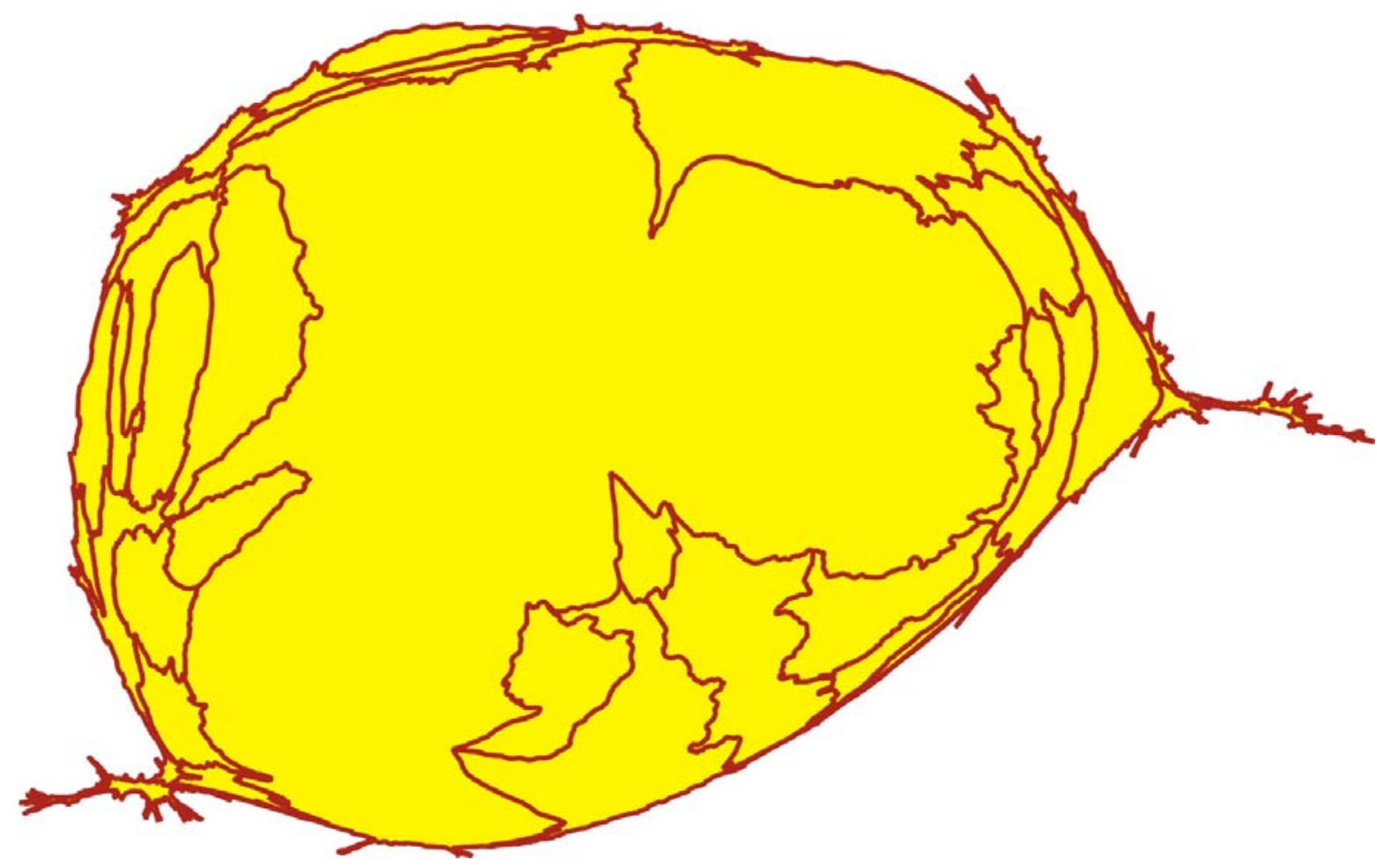

Mapa 19 - Fundo de mapa não euclidiano: Mapa em anamorfose - População do ano de 2.000

Figura 41 - A geometrização da síntese 2

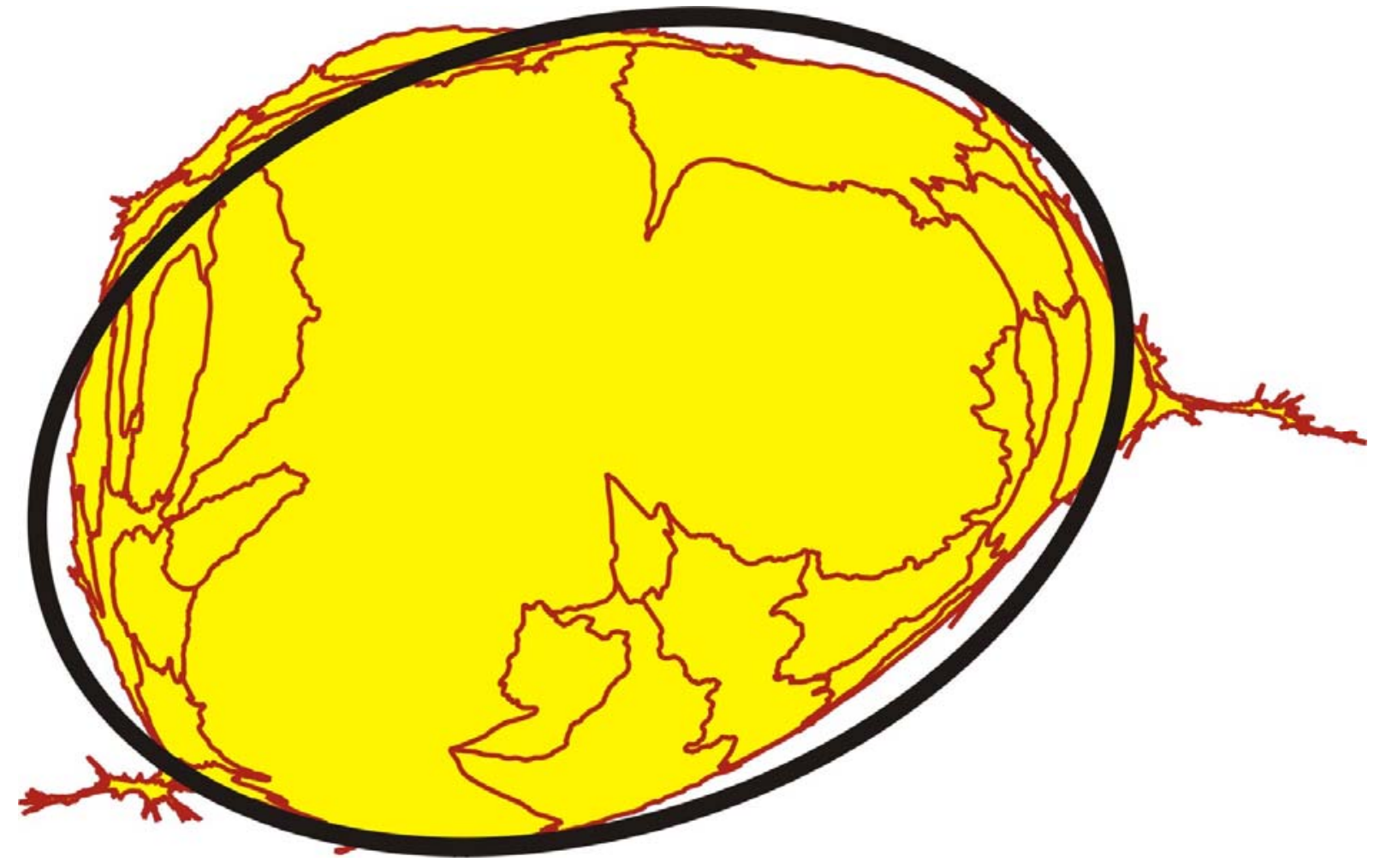




\section{Um "novo fundo"}

Figura 42 - Modelo elementar 12 - Nosso "Maillage" - O limite metropolitano

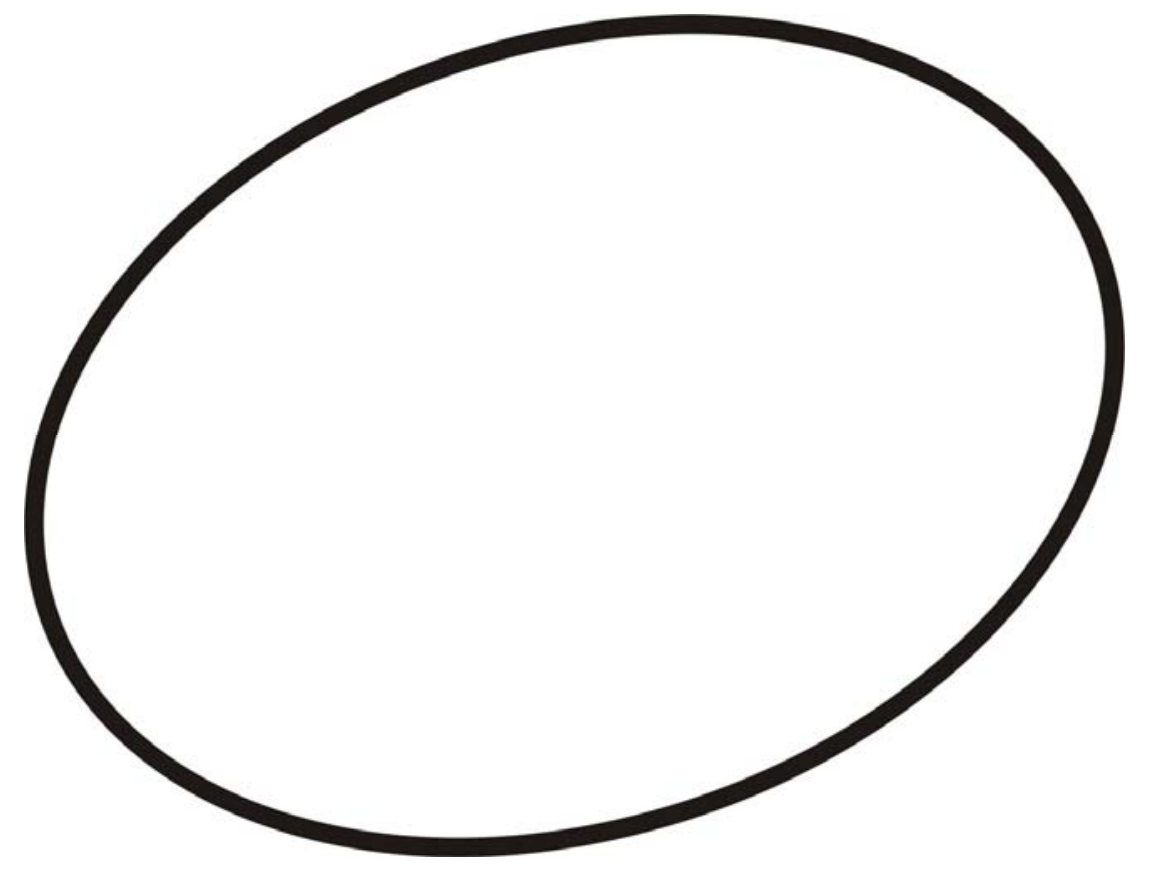

Figura 43 - Modelo elementar 13 - "Gravitation" - [gravitação]: A força de atração do centro da metrópole

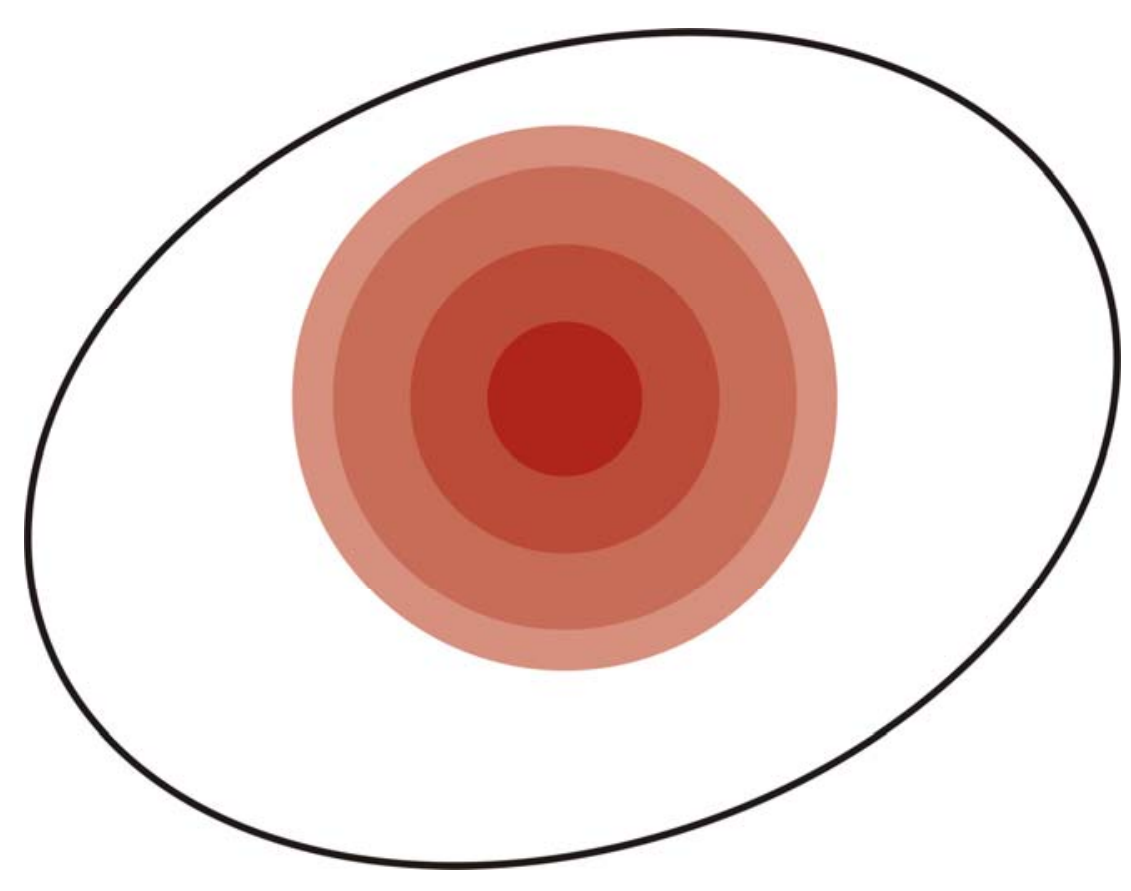


Figura 44 - Modelo elementar 14 - "Hiérarquie" - [hierarquia]: Centros secundários da metrópole

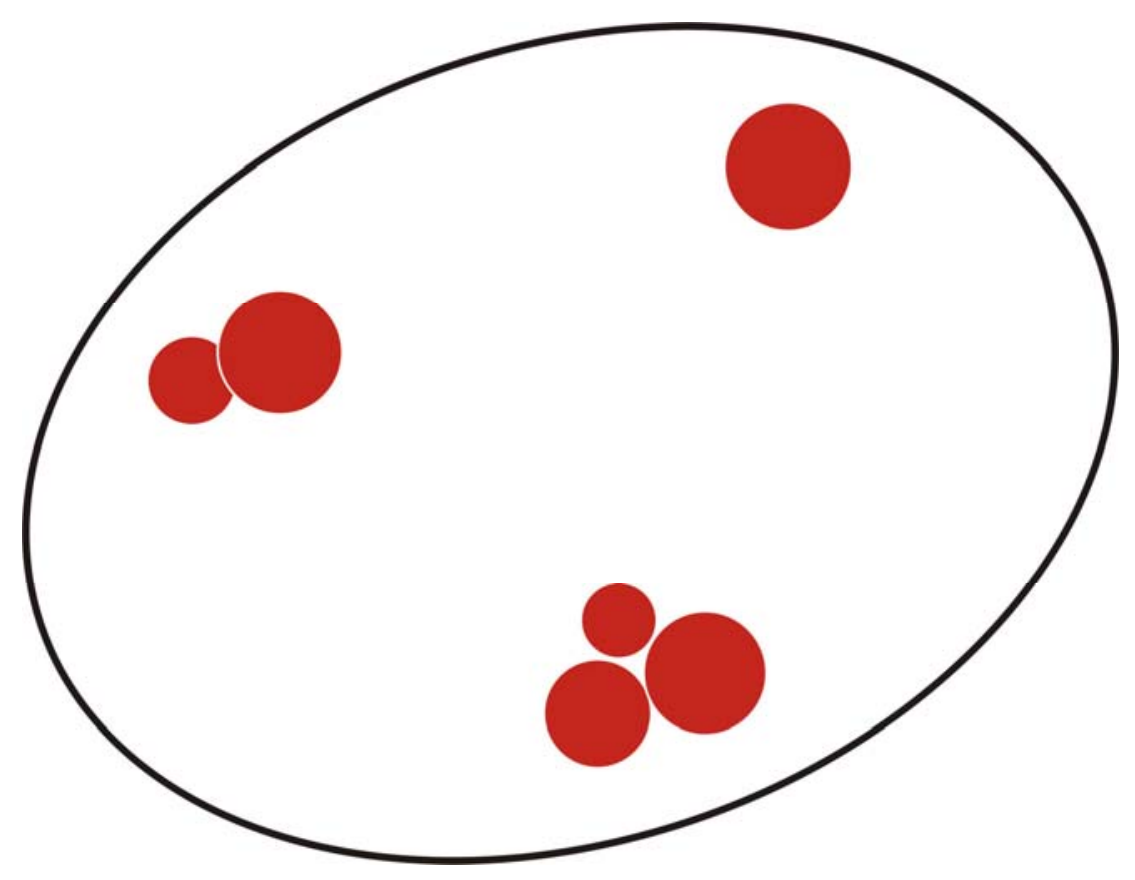

Figura 45 - Modelo elementar 15 - "Hiérarquie" e "Dynamique territoriale"[hierarquia, dinâmica territorial]: área do centro principal e secundário da metrópole => o "file"; área de extensão, expansão.

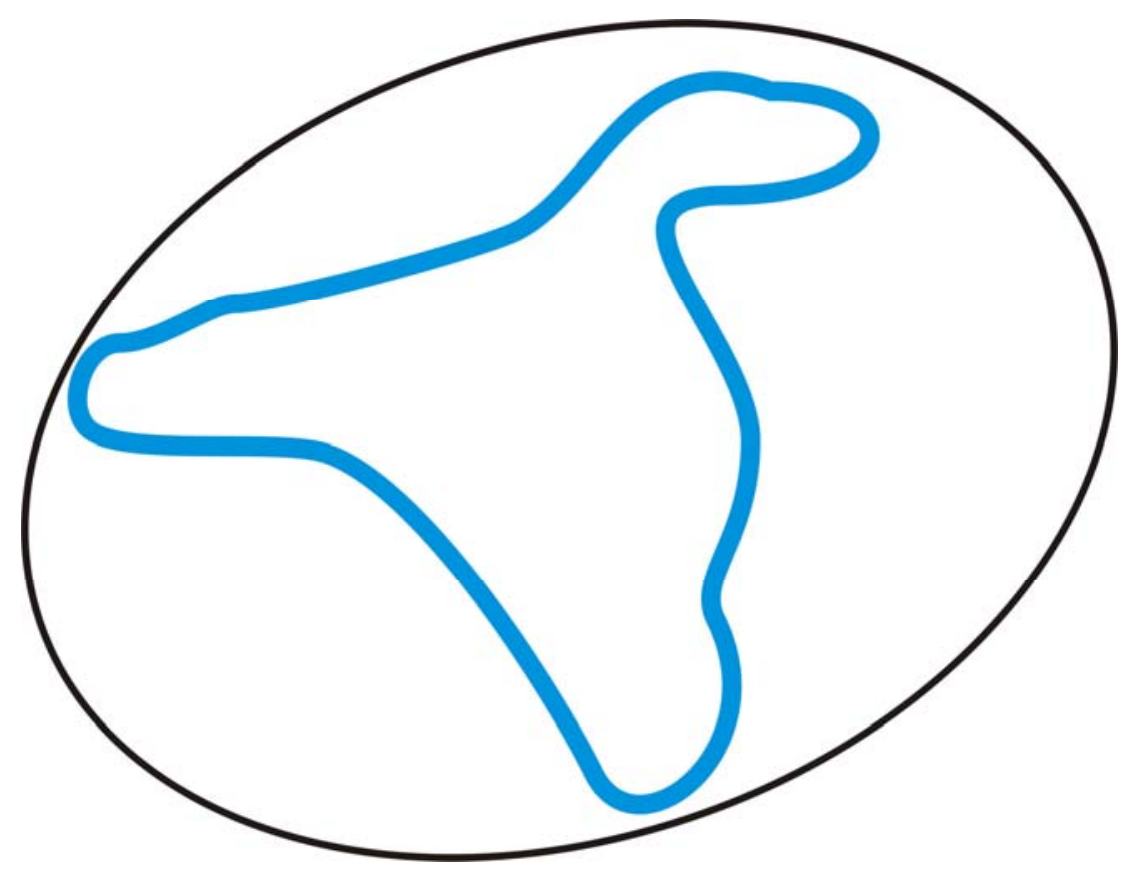

125 
Figura 46 - Modelo elementar 16 - "Treillage" - [ligação]: rede principal de vias de comunicação - as rodovias -[baseado na rede viária do Mapa 10]

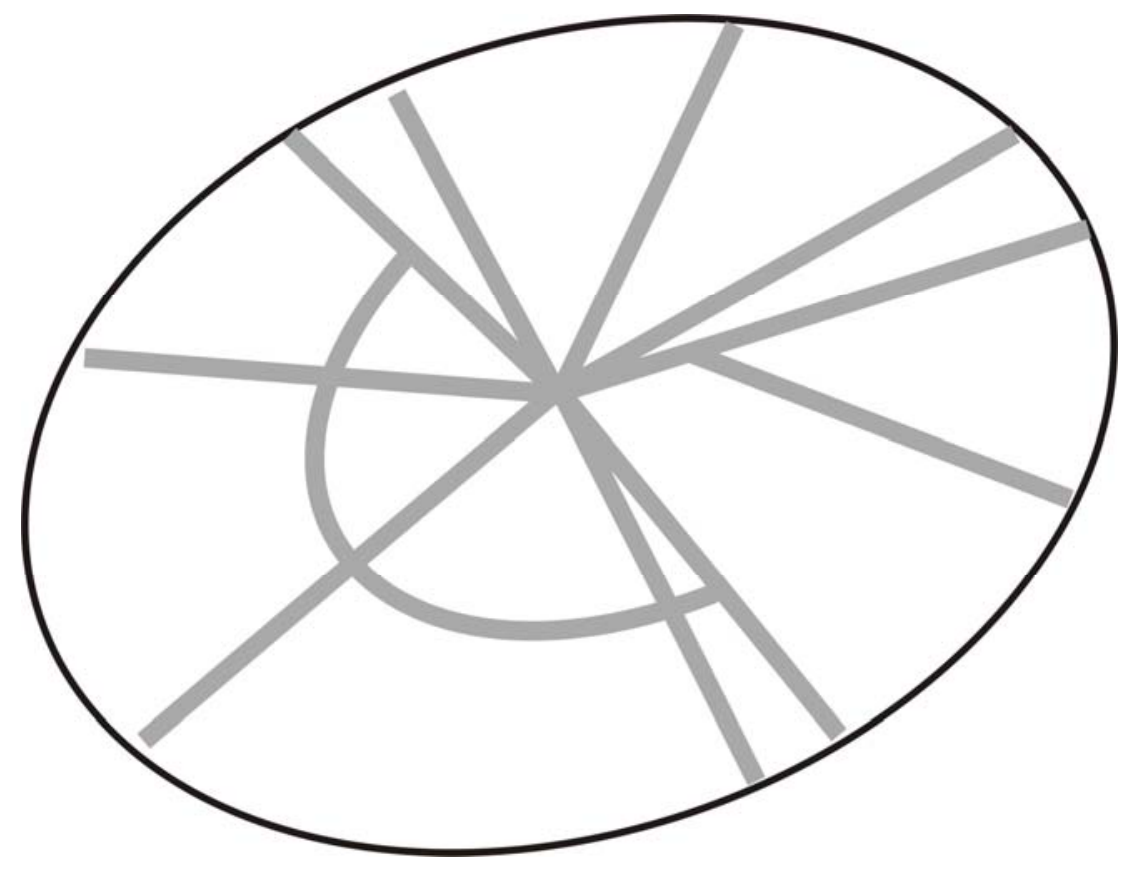

Figura 47 - Modelo elementar 17 - "contact" - [contato]: interface urbano e áreas de proteção ambiental - limites da expansão urbana. [modelo baseado nos mapas da EMPLASA]

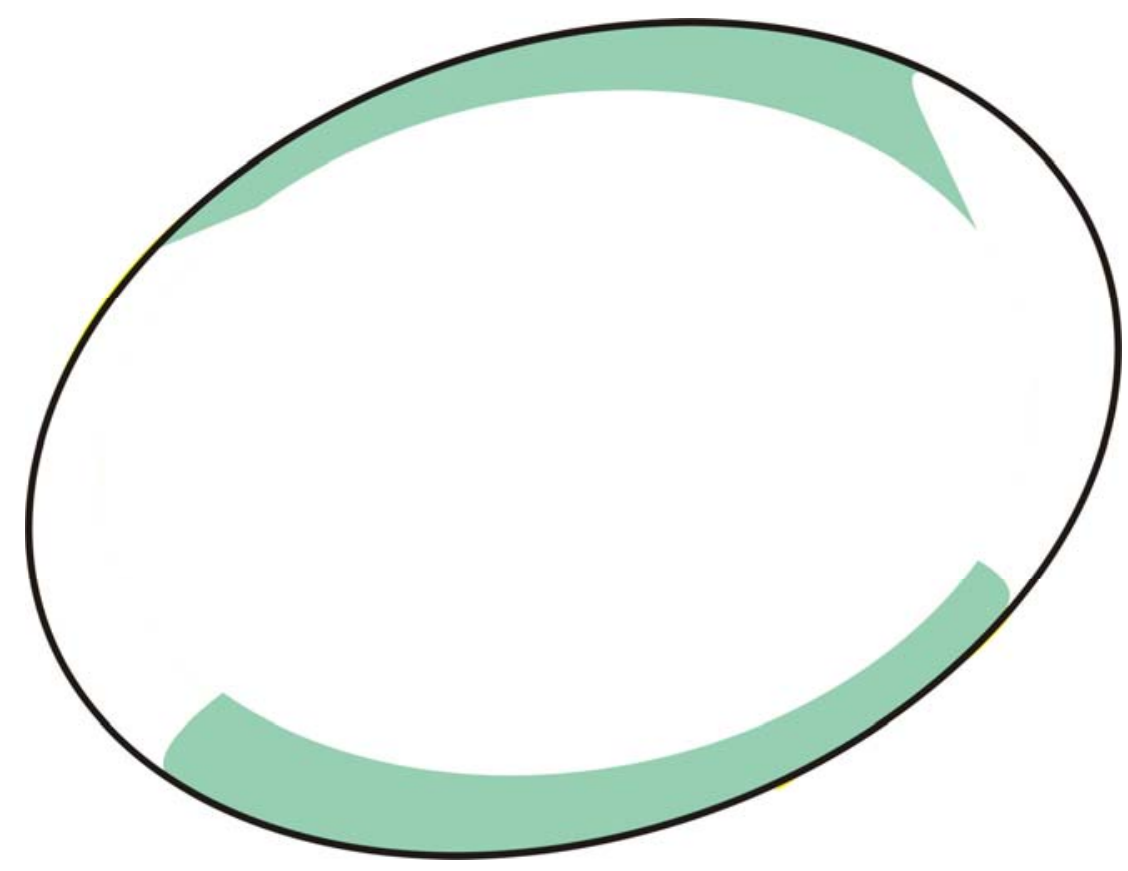


Figura 48 - Modelo elementar 18 - "Dynamique territoriale"- área de "regressão" => área "problema"

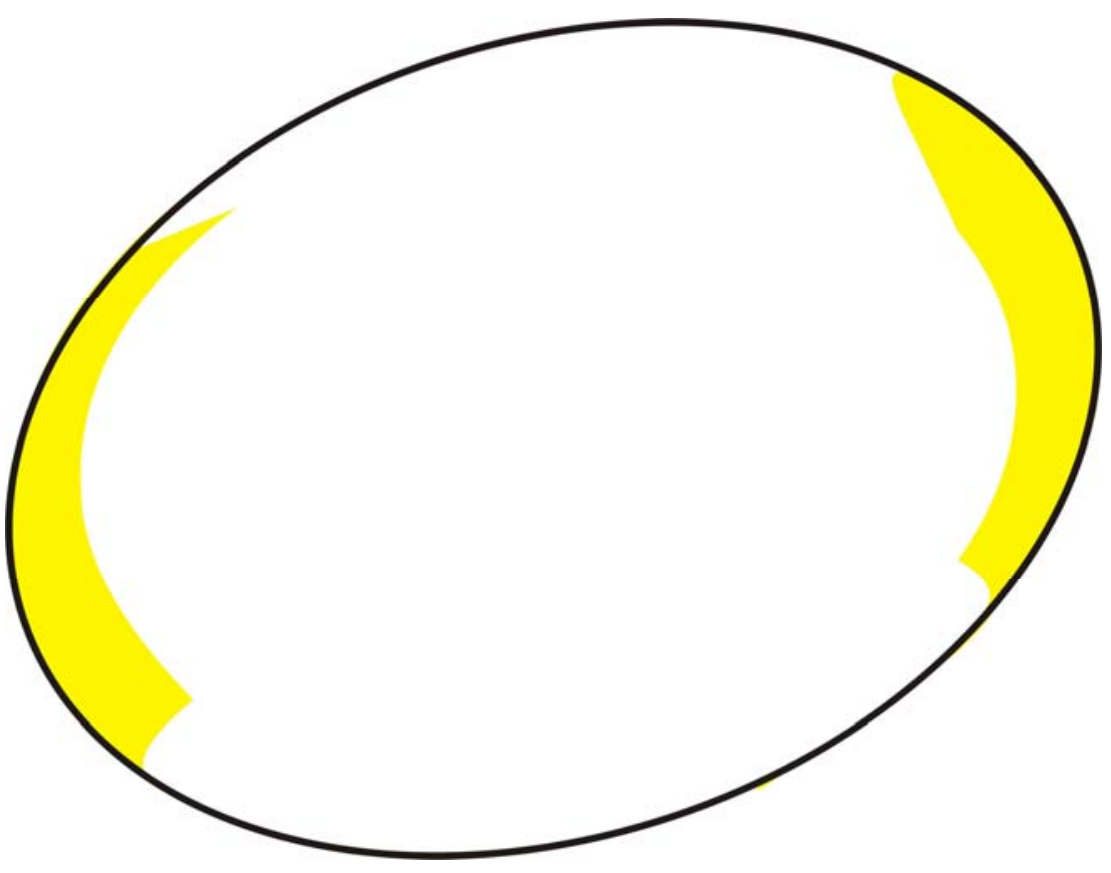

Figura 49 - A segunda síntese

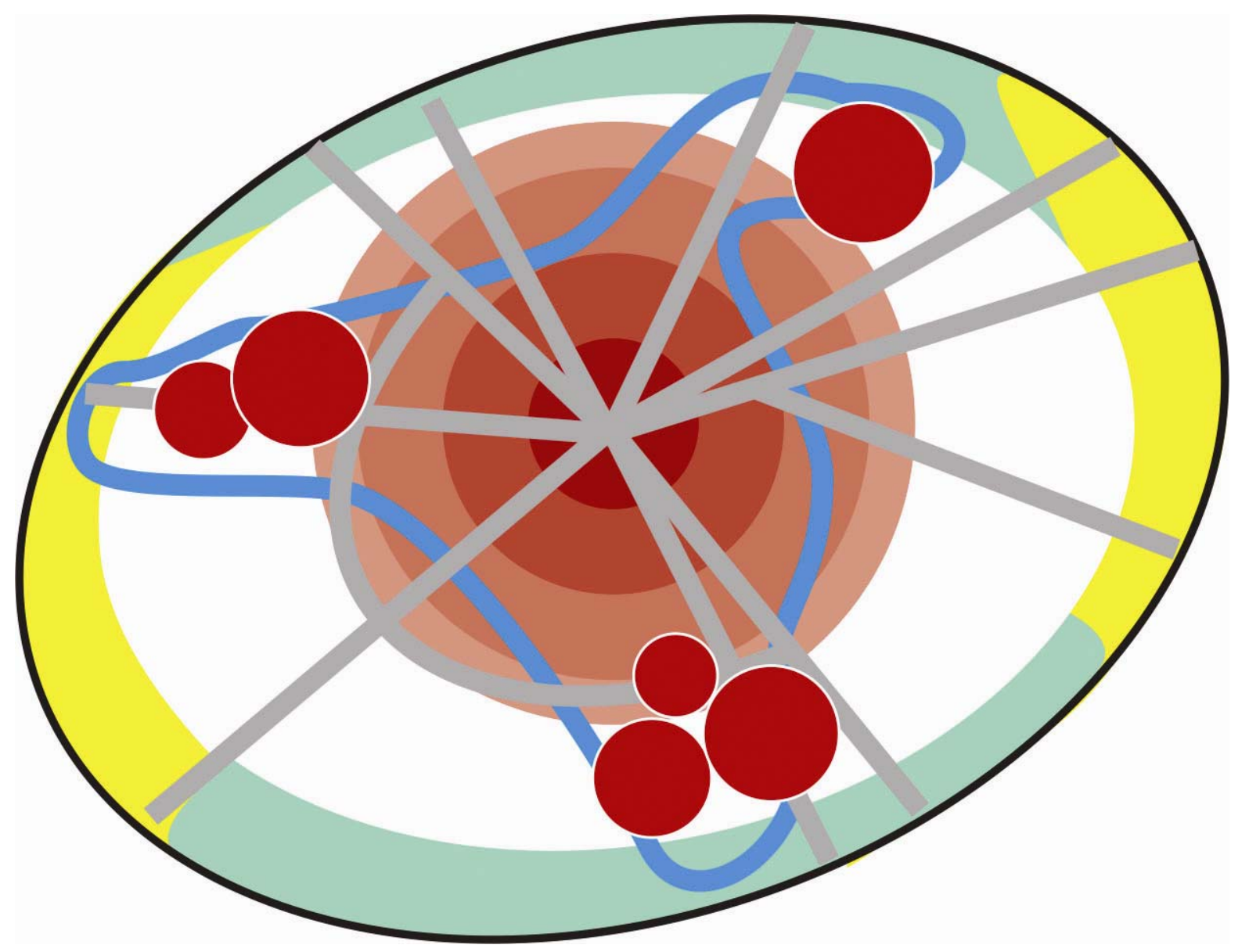




\section{3 - Análises e avaliações}

A duas sínteses testadas nos revelam imagens não comuns para o espaço urbano da metrópole paulistana. É aplicável nosso método de análise proposto no capítulo 3 ? Vamos tentar.

O espaço de referência continua sendo a metrópole paulista. Mas foi metamorfoseada, com uma mudança radical de sua aparência visual tradicional - 0 fundo euclidiano - para um modelo em trapézio escaleno e/ou uma elipse.

A escala cartográfica não é aplicável. Não tem sentido medir em metros ou quilômetros. Contudo, a síntese 1 foi fruto fundamentalmente dos mapas do capítulo 4 - que possuem escalas cartográficas explicitas. Escalas de detalhe que refletiram e influenciaram na modelização.

Qual o princípio que norteou a transposição analógica do espaço referente para o espaço no mapa? O nosso referente sofreu diversas transformações cartográficas até culminarem em um produto, o mapa. A modelização começa a partir deste "final". Sofre uma espécie de desconstrução, é a partir do que o[s] mapa[s] revela[m] que são elaborados os modelos elementares [coremas].

Métricas: Para Lévy (2007d) a métrica é a forma com que medimos distâncias sociais e para Brunet (2001) a distância é fundamental para relacionar estruturas. Os dois autores não possuem a mesma visão de espaço geográfico: Lévy estaria mais para um espaço geográfico do tipo Leibniziano, isto é, de simultaneidade, "ordem de coexistência" do tipo "relativo e relacional... relacional como razão de realidades sociais" (LÉVY, 2007f, p. 550, tradução nossa) e Brunet mais no sentido absoluto/relativo, em configurações espaciais, em estruturas diferenciadas no espaço. Esta diferença não impede de utilizarmos o conceito de métrica como fundamental para relacionar distâncias. É um avanço significativo que, na modelização gráfica, a métrica não é euclidiana. Em nossas sínteses não são possíveis de quantificá-las como num mapa em anamorfose que oferece uma "escala" do tipo número de habitantes, valor de PIB, etc, mas estão "embutidas" na modelização, mesmo a euclidiana, nos modelos de estruturas de indústria, "vegetação", etc. No modelo elementar 6 - Centros de população residente expressam a densidade populacional oriunda do mapa em anamorfose do dasimétrico, que é a métrica do número de habitantes. 
"Temas", substâncias contempladas. Diversos: homens, mulheres, crianças que nomeamos como número de habitantes; $O$ produto interno bruto municipal - que é o total de "riqueza" econômica produzida pela sociedade; emprego em setores econômicos diversos, índices de desenvolvimento, que por sua vez expressam níveis de longevidade humana, educação e novamente a riqueza econômica, enfim, "componentes não espaciais de configurações espaciais". Substâncias que oferecem os modelos de estruturas elementares de hierarquia urbana, atração - a pujança do seu centro, áreas "file" e "problemas", etc.

Semiologia: A modelização gráfica segue as bases da semiologia gráfica de Bertin, contudo, as duas sínteses apresentadas são bastante abstratas para a compreensão em uma única apreensão visual do tipo de mapas "para ver" de Bertin (1988). É necessário primeiro "ler" a sequência dos modelos para, posteriormente, 'enxergar' o todo expresso na síntese e relacioná-los.

Quanto ao tipo de transformação cartográfica, já comentamos acima que a modelização é uma pós-transformação. Ela começa quando o produto mapa está finalizado. Neste sentido é uma pós-cartografia.

À questão de tratar a modelização como mapas "à leitura espacial" ou não, somos tentados a classificá-los como "mapas-modelos" "à leitura espacial", com a ressalva de que seria um "mapa-modelo' a "ler" e não "para ver". Com um fundo nada convencional seriam do tipo de "mapas auto-extensivos" . 


\section{Conclusões finais}

Com o final desta jornada é necessário voltar ao início de nossas indagações e verificar se foram razoavelmente saciadas.

Nos finais dos capítulos 4, 5 e 6 encontramos detalhes mais específicos de nossas conclusões e avaliações, dos três modos de representação que escolhemos para o espaço geográfico.

De um modo geral acreditamos que os objetivos gerais foram cumpridos, isto é, produzimos os mapas de densidade urbana [em particular a densidade de população] da metrópole de São Paulo aplicando as técnicas coroplética e dasimétrica. Analisamos e comparamos os resultados das duas técnicas e concluímos que o dasimétrico apresentou e transmitiu informações de localizações e distribuições de densidades populacionais mais relevantes que o coroplético. Apresentamos e elaboramos, com as anamorfoses, alternativas significativas que focam nosso olhar em imagens que expressam densidades. Na modelização gráfica fizemos um exercício com duas sínteses finais revelando imagens incomuns para o espaço geográfico, em particular para o espaço da metrópole paulista.

Cada representação testada por nós apresentou suas virtudes e insuficiências. O mapa dasimétrico é um representante de uma concepção de espaço absoluto, mas que contribuiu para avaliar o espaço urbano revelando os seus espaços densos, significativos, mesmo dentro da lógica de fundo de mapa euclidiano.

Os mapas em anamorfose e cartograma em anamorfose são candidatos a se enquadrarem na concepção de espaço relativo/relacional, devido principalmente à possibilidade de estabelecer outras métricas além da euclidiana. Não significa que é a solução, pois estamos caminhando ainda para ter um representante à altura, que mostre a simultaneidade, a "ordem de coexistência" das relações sociais. É este o desafio da Cartografia-Geográfica.

A modelização gráfica, por sua vez, repousa em uma concepção de espaço absoluto/relativo, como já escrevemos no final do capítulo 6. Contudo, usamos os dois tipos de mapas anteriores e, portanto, com duas concepções de espaço geográfico diferentes como orientadores na elaboração dos modelos elementares. É 
também um caminho válido e necessário. Devemos continuar desenvolvendo novas reflexões.

Além dos objetivos cumpridos, conseguimos avançar um pouco mais e sugerir alguns eixos ou métodos que orientaram as nossas análises, avaliações e classificações para com as três formas de representação espacial. É um início de criação de procedimentos que auxiliem avaliações fundamentadas em reflexões teóricas da Geografia e Cartografia em direção a uma Cartografia-Geográfica. 


\section{Referências Bibliográficas}

ABBAGNANO, Nicola. Dicionário de Filosofia. São Paulo: Martins Fontes, 1998. $1014 \mathrm{p}$.

ACIOLY, C. DAVIDSON, F. Densidade urbana: um instrumento de planejamento e gestão urbana. Tradução de Cláudio Acioly. Rio de Janeiro: Mauad, 1998. Título original: Density in urban development.

ALMEIDA, Cláudia Maria de; O Diálogo entre as dimensões real e virtual do urbano In: CÂMARA, Gilberto; MONTEIRO, Antonio Miguel V. (org.). Geoinformação em urbanismo: cidade real x cidade virtual. São Paulo: Oficina de Textos, 2007. 368 p. ARCHELA, R. S. Análise da cartografia brasileira: bibliografia da cartografia na geografia no período de 1935-1997. São Paulo: Universidade de São Paulo, 2000. Disponível em:< http://www.uel.br/projeto/cartografia> Acesso: 21/09/2006.

AURIAC, Franck. Modèle. In : BRUNET, Roger. FERRAS, Robert. THÉRY, Hervé. Les mots de la géographie, dictionnaire critique. Montpellier-Paris: RECLUS / La Documentation française, 1993. 520 p.

BEAUDE, Boris. Éléments pour une géographie du lieu réticulaire. Thèse de doctorat, Université Paris 1, juin, p. 99-164, 2008. Disponível em:<http://sciencespo.macrocosme.net/lectures/BeaudeTheseAvoirlieu99-164.pdf >Acesso: 12/11/2009.

BERTIN, Jacques. Ver ou ler. Seleção de Textos (AGB), São Paulo, n.18, p. 45-62, maio 1988.

BIELECKA, Elzbieta. A Dasymetric population density map of Poland. Disponível em:<http://www.cartesia.org/geodoc/icc2005/pdf/oral/TEMA5/Session\%209/ELZBIET A\%20BIELECKA.pdf>. Acesso: 21/07/2006.

BÓGUS, Lúcia Maria Machado, PASTERNAK, Suzana (orgs). Como anda São Paulo. Rio de Janeiro: Letra Capital: Observatório das Metrópoles, 2009.

BORTOLUZZI, S. D. e HOCHHEIM, N. O Geoprocessamento para caracterização dos padrões de densidade populacional do centro de Florianópolis (SC). COBRAC 2004. Congresso Brasileiro de Cadastro Técnico Multifinalitário. UFSC Florianópolis. 10 a 14 de outubro de 2004. Disponível em: <geodesia.ufsc.br/Geodesia-online/arquivo/cobrac_2004/119.pdf> Acesso: 23/01/2007. 
BRUNET, Roger. La carte, mode de emploi. Paris: Fayard/Reclus, 1987.

BRUNET, Roger. Des modèles en géographie? Sens d'une recherche. Bulletin de la Société de Géographie de Liège, 2000, n², p. 21-30. Disponível em :

<http://www.mgm.fr/ARECLUS/page_auteurs/Brunet3.html> Acesso: 16/02/2010

BRUNET, Roger, Le déchiffrement du monde, théorie et pratique de la géographie. Paris: Belin, 2001, 402 p.

BRUNET, R. Roger Brunet. In: Sylvain Allemand (dir.), Comment je suis devenu géographe. Paris : Le Cavalier Bleu, 2007.

CÂMARA, Gilberto; MONTEIRO, Antônio Miguel Vieira; RAMOS. R. F. Territórios Digitais Urbanos In: CÂMARA, Gilberto; MONTEIRO, Antonio Miguel V. (org.).

Geoinformação em urbanismo: cidade real x cidade virtual. São Paulo: Oficina de Textos, 2007. 368 p.

CÂMARA, Gilberto. Representação computacional de dados geográficos. São José dos Campos: INPE, 2005. Disponível em:

<www.dpi.inpe.br/livros/bdados/cap1.pdf> acesso: 21/02/2006

CASTI, Emanuela. Cartographie. In: LÉVY: Jacques; LUSSAULT, Michel (Org).

Dicitonnaire de la Géographie et de I' espace des sociétes. Paris: Belin, 2003,

p. 134-135. Tradução de trabalho de Fernanda Padovesi Fonseca e Jaime Oliva.

CAUVIN, Colette. Transformações cartográficas espaciais e anamorfoses. In: DIAS, Maria Helena (coord). Os mapas em Portugal: da tradição aos novos rumos da Cartografia. Lisboa: Cosmos. 1995. p. 269-310.

CAUVIN, Colette. ESCOBAR, F. ,SERRADJ, A. Cartographie Thématique 1. Paris : Lavoisier, 2007.

CAUVIN, Colette. ESCOBAR, F. ,SERRADJ, A. Cartographie Thématique 1. Paris : Lavoisier, 2008.

CHAUÍ, Marilena de Souza. Leibniz. Vida e Obra. in Os Pensadores - Newton e Leibniz. São Paulo: Abril Cultural, 1979.

CLAVAL, Paul. A revolução pós-funcionalista e as convenções atuais da geografia. In: MENDONÇA, Francisco. KOZEL, Salete (orgs). Elementos de Epistemologia da Geografia Contemporânea. Curitiba: Ed. da UFPR, 2002. 
CORRÊA, Roberto Lobato. Região e organização espacial. 7. ed. São Paulo: Ática, 2002.

CRISTOFOLETTI, Antonio. As Perpectivas dos estudos Geográficos.

Disponível em:http:// sites.uol.com.br/ivair/index.html. Acesso em 21/08/2002

CHRISTOFOLETTI, Antonio; TEIXEIRA, Amandio Luís de Almeida. Sistemas de Informação Geográfica: Dicionário llustrado. São Paulo: HUCITEC, 1997.

DIAS, Maria Helena. Carto-grafias ou a reflexão sobre o impacto dos computadores na concepção cartográfica. Finisterra - Volume XXVI, número 52, Lisboa: 1991. Disponível em: <http://www.ceg.ul.pt/finisterra/numeros/1991-52/52_06.pdf>. Acesso: 05/01/2009

DEBARBIEUX, Bernard. Représentation. In: Lévy, Jacques; Lussault Michel (Org.). Dicitionnaire De La Géographie Et De L’Espace Des Sociétés. Paris: Belin, 2003, p.791.

DEBARBIEUX, Bernard. Representación. Disponível em: <www. Hypergeo.eu> Acesso: 07/09/2009

DOUGENIK, James. A. CHRISMAN, Nicholas, R. NIEMEYER, Duane, R. An algorithm to construct continuous area cartograms. Professional Geographer, 37 (1): 75-81.1985.

EMPRESA PAULISTA DE PLANEJAMENTO METROPOLITANO - EMPLASA. Mapa de Uso e Ocupação do Solo da Região Metropolitana de São Paulo. São Paulo: Empresa Paulista de Planejamento Metropolitano S/A, 3 CD-ROM - versão 2, 2005.

ENVIRONMENTAL SYSTEMS RESEARCH INSTITUTE (ESRI) - ARCGIS 9.1 1999-2005.

FABRIKANT, S. I. Commentary on 'A History of Twentieth-Century American Academic Cartography' by Robert McMaster and Susanna McMaster. Cartography and Geographic Information Science 30: 81-4. 2003.

FONSECA, F.P. OLIVA, J.T. A Geografia e suas linguagens: o caso da cartografia. In: CARLOS, A. F. A. A Geografia em sala de aula. São Paulo: Contexto, 2001. 
FONSECA, F.P. A inflexibilidade do espaço cartográfico, uma questão para a Geografia: análise das discussões sobre o papel da Cartografia. São Paulo, Tese (Doutorado em Geografia), FFLCH/USP, 2004.

FUNKHOUSER ,H. Gray. Historical Development of the Graphical Representation of Statistical Data. Osiris, Vol. 3, 269-404 p. 1937.

GEER, Sten de. A Population Density Map of European Rússia. Reviewed work(s): Dazimetricheskaya Karta Evropeiskoi Rossii (Carte dasymetrique de la Russie d'Europe) by Benjamin Semenov-Tian-Shansky. Geographical Review, Vol. 16, No. 2 (Apr., 1926), p. 341-343 GOMES, Paulo César da Costa. O Conceito de Região e sua discussão. in: CASTRO, Iná Elias e outros. Geografia: conceitos e temas. Rio de Janeiro: Bertrand Brasil, 1995, páginas 49-73.

GRATALOUP, Christian. Chorème. In: LÉVY, Jacques; LUSSAULT, Michel (Org.). Dicitionnaire de la Géographie et de l’espace des sociétés. Paris: Belin, 2003a. p. 154-155.

GRATALOUP, Christian. Modélisation graphique. In: LÉVY, Jacques; LUSSAULT, Michel (Org.). Dicitionnaire de la Géographie et de l'espace des sociétés. Paris: Belin, 2003b. p. 629-631.

HARLEY, J. Brian. A nova história da cartografia. O Correio da UNESCO (Mapas e cartógrafos), Brasil, ano 19, n. 8, ago. 1991, p. 4-9.

HARLEY, John Brian. Textos y contextos em la interpretación de los primeros mapas. In: La nueva naturaleza de los mapas. Ensayos sobre La historia de La cartografia. México: FCE, 2005.

HARTHSHORNE, R. Propósitos e natureza da Geografia. São Paulo: Hucitec, 1978.

INSTITUTO BRASILEIRO DE GEOGRAFIA E ESTATÍSTICA - IBGE. Metodologia do Censo Demográfico 2000. Rio de Janeiro: IBGE, 2003.

JAMMER, Max. Conceitos de espaço: a história das teorias do espaço na física. Rio de Janeiro: Contraponto: Ed. PUC-Rio, 2010.

LEIBNIZ, G.W. Correspondência com Clarke. in Os Pensadores - Newton e Leibniz. São Paulo: Abril Cultural, 1979. 
LÉVY, Jacques. Anamorphose. In: Lévy, Jacques; Lussault Michel (Org.).

Dicitionnaire De La Géographie Et De L’Espace Des Sociétés. Paris: Belin, 2003a. P. 74. Tradução de trabalho de Fernanda Padovesi Fonseca e Jaime Tadeu Oliva.

.Carte. In: LÉVY, Jacques ; LUSSAULT, Michel (Org.). Dictionnaire de la Géographie et de l'espace des sociétes. Paris: Belin, 2003b. p. 128-132. Tradução de trabalho de Fernanda Padovesi Fonseca e Jaime Tadeu Oliva.

.Densité. In: Lévy, Jacques; Lussault Michel (Org.). (Org.).

Dicitionnaire de la Géographie et de l'espace des sociétés. Paris: Belin, 2003c,p. 237-238.

.Espace. In: LÉVY, Jacques; LUSSAULT Michel (Org.).

Dicitionnaire de la Géographie et de l'espace des sociétés. Paris: Belin, 2003d.

p. 325. Tradução de Mônica Balestrin Nunes.

.Euclidien (Espace). In: LÉVY, Jacques; LUSSAULT, Michel (Org.).

Dictionnaire de la Géographie et de l'espace des sociétés. Paris: Belin, 2003e. p. 351. Tradução de trabalho de Fernanda Padovesi Fonseca e Jaime Tadeu Oliva. .Leibnizien (Espace). In: Lévy, Jacques; Lussault Michel (Org.)..).

Dicitionnaire de la Géographie et de l'espace des sociétés. Paris: Belin, 2003f, p. 550.

.Métrique. In: Lévy, Jacques; Lussault Michel (Org.)..). Dicitionnaire de la Géographie et de l'espace des sociétés. Paris: Belin, 2003g, p. 607.

Substance. In: Lévy, Jacques; Lussault Michel (Org.). Dicitionnaire de la Géographie et de l'espace des sociétés. Paris: Belin, 2003h, p. 880.

LÉVY, Jacques. La carte, un espace à construire. In: LÉVY, Jacques; PONCET, Patrick; TRICOIRE, Emmanuelle. La carte, enjeu contemporain. Documentation photographique $n^{\circ}$ 8036. Paris: La Documentation Française, 2004. p. 1-14

LÉVY, Jacques. Uma virada cartográfica? In: ACSELRAD, Henri (org.). Cartografias sociais e território. Rio de Janeiro: UFRJ/IPPUR, 2008. p. 153-167.

MacEACHREN, Alan M. The Evolution of thematic Cartography. A Research Metthodology and Historical Review. The Canadian Cartographer 16/1: 17-33. 1979. 
MAANTAY, Juliana Astrud, MAROKO, Andrew R e HERRMANN, Christopher. Mapping Population Distribution in the Urban Environment: The Cadastral-based Expert Dasymetric System (CEDS). Cartography and Geographic Information Science, Vol. 34, No. 2, 77-102 p., 2007

MARTINELLI, M. Curso de Cartografia Temática. São Paulo: Contexto, 1991.

MENNIS, J. and HULTGREN, T. Intelligent dasymetric mapping and its application to areal interpolation. Cartography and Geographic Information Science, 33(3): 179194.2006. Disponível em:< http://astro.temple.edu/ jmennis> Acesso: 14/09/2006 MORAES, Antonio Carlos Robert. Capitalismo, Geografia e Meio Ambiente. São Paulo: Tese (Livre Docente em Geografia), FFLCH/USP, 2000. Geografia - Pequena História Crítica. 18a. ed.

São Paulo: Hucitec, 2002.

MONBEIG, Pierre. Novos Estudos de Geografia Humana Brasileira. São Paulo: Difusão Européia do Livro, 1957.

NEWTON, I. Princípios Matemáticos. In: Os Pensadores - Newton e Leibniz. São Paulo: Abril Cultural, 1979.

OLIVA, J. \& GIANSANTI, R. Espaço e Modernidade: temas de Geografia do Brasil. São Paulo: Atual, 1.999.

OLIVA, Jaime. A cidade como ator social - a força da urbanidade. In: CARLOS, Ana Fani Alessandri; LEMOS, Amália Inês Geraiges. Dilemas Urbanos: novas abordagens sobre a cidade. São Paulo: Contexto, 2003. p.73 - 80 OLIVEIRA, C. 1993: Cartograma. In Dicionário Cartográfico. Rio de Janeiro: IBGE. p.86.

PALSKY, Gilles. Origines et évolution de la cartographie Thématique (XVII_XIX siècles). Revista da Faculdade de Letras - Geografia I série, vol. XIV, Porto, p. 3960, 1998. Disponível em: <http://ler.letras.up.pt/uploads/ficheiros/1607.pdf> Acesso:1/06/2007

. Carta. Disponível em: <www.hypergeo.eu> Acesso: 07/09/2009 
PETROV, Andrey N. On the Russian origins of dasymetric mapping. Cartographica - The International Journal for Geographic Information and Geovisualization volume 43, issue 2, 133-136 p., 2008.

POVEDA, Miguel-Angel Bernabé. AGUIRRE, Teresa Iturrioz. Elementos del Diseño Cartográfico (Capítulo 7. Mapas dasimétricos). Universidade Politécnica de Madri. Deparamento de Ingenieria Topográfica y Cartografia. 1994. Disponível em: <http://nivel.topografia.upm.es/ mab/apuntesalumnos/2.7_dasimet.pdf> Acesso: $6 / 06 / 2006$

RAISZ, Erwin. The Rectangular Statistical Cartogram. Geographical Review, Vol. 24, No. 2, 292-296.p. Apr., 1934.

RAISZ, Erwin. Cartografia Geral. Rio de Janeiro: Científica, 1969.

ROBINSON, Arthur. H. The thematic maps of Charles Joseph Minard. Imago Mundi, Vol. 21, 95-108 p., 1967.

ROBINSON, Arthur. H. The 1837 Maps of Henry Drury Harness. The Geographical Journal 121: 440-50 p., 1955.

SANTOS, Milton. Por uma Geografia Nova. São Paulo: EDUSP, 2002a. . A Natureza do Espaço: Técnica e Tempo, Razão e Emoção. São Paulo: EDUSP, 2002b. Espaço e método. São Paulo: EDUSP, 2008.

SCHENBERG, Mário. Pensando a Física. São Paulo: Brasiliense, 1984.

THÉRY, Hervé. Modelização gráfica para a análise regional: um método, Geousp Espaço e Tempo n`15, pp. 179-188, 2004.

. Chaves para a leitura do território paulista. In: Atlas Seade da economia paulista. Disponível em:

$<$ http://www.seade.gov.br/produtos/atlasecon/index.php?texto=mapa\&cap_cod=11> Acesso: 30/09/2008

TOBLER, Waldo. Map transformations of geographic space. Ph.D. Thesis, University of Washington, Seattle (University Microfilm \#61-4011).1961. Disponível em: <http://www.geog.ucsb.edu/ tobler/index.html> Acesso: 24/09/2007. 
. Interactive construction of contiguous cartograms. Computer

Graphics, 13-17. Anaheim, CA: National Computer Graphics Association

Conference.1984. Disponível em: <http://www.geog.ucsb.edu/ tobler/index.html> Acesso: 24/09/2007.

. Thirty-Five Years of Computer Cartograms. Annals of the Association of American Geographers, 94(1), 58-73 p. 2004.

SEMENOV-TIAN-SHANSKY, Benjamin. Territory and Population: A Perspective on the 1926 Census. Geographical Review, Vol. 18, No. 4 (Oct., 1928), p. 616-640. WOLF, Eric, B. Creating Contiguos Cartograms in ArcGIS9. Disponível em: <http://gis.esri.com/library/userconf/proc05/papers/pap1155.pdf> acesso: 09/04/2007 WRIGHT, J.K. A method of mapping densities of population with Cape Cod as an example. Geographical Review, 26, 103-110. 1936. 


\section{ANEXOS}

[Mapas em formato A3] 


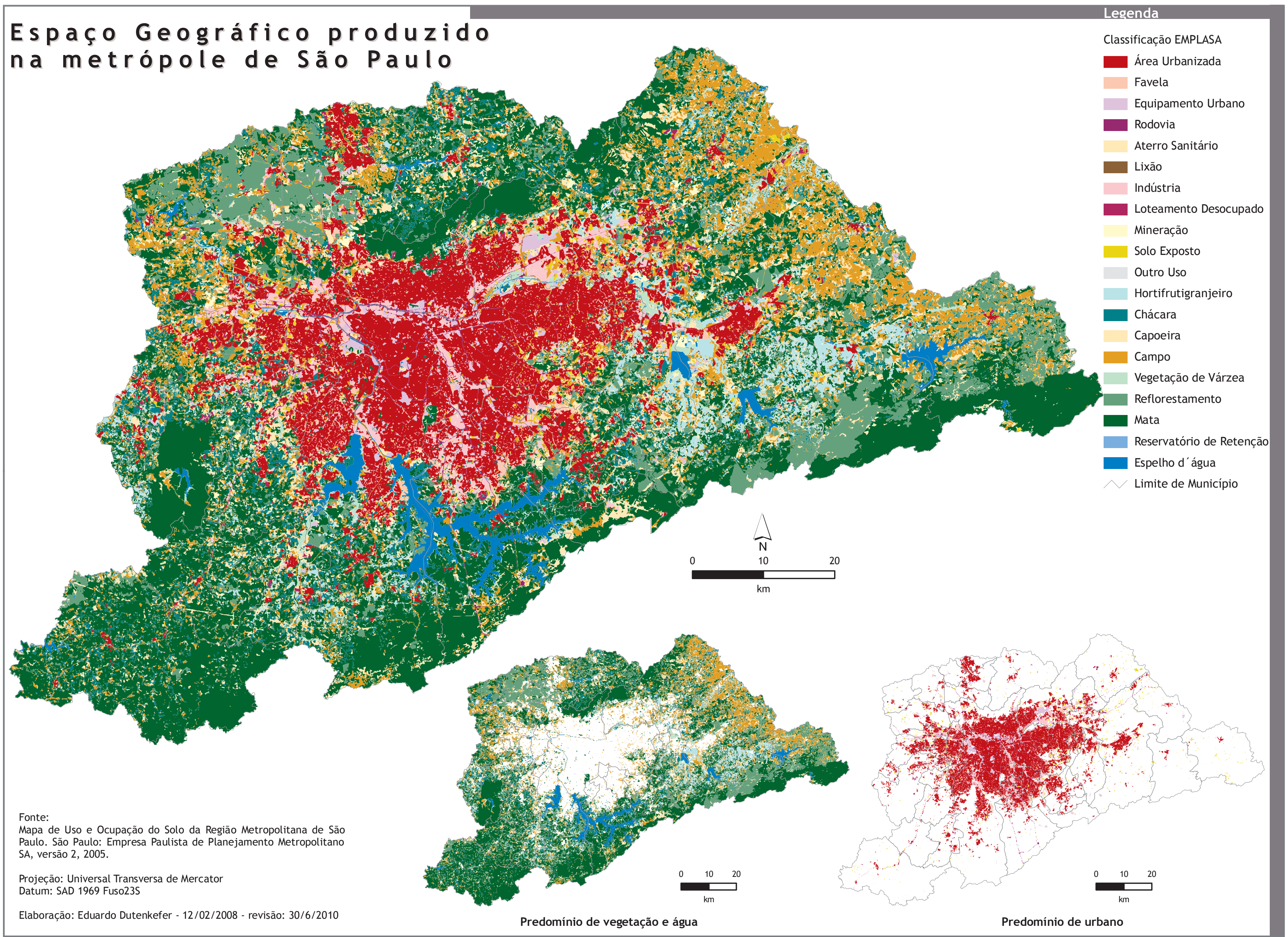




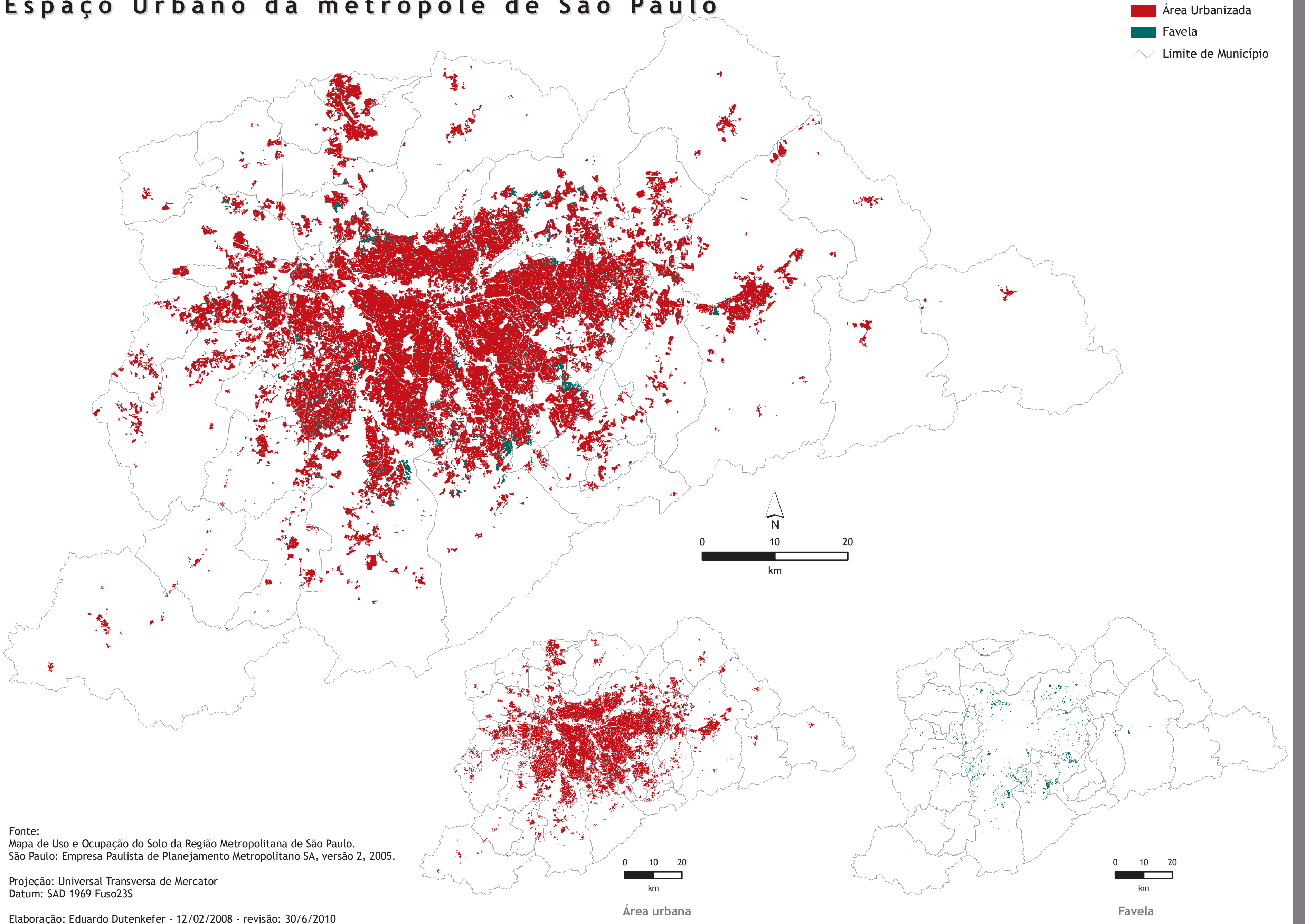




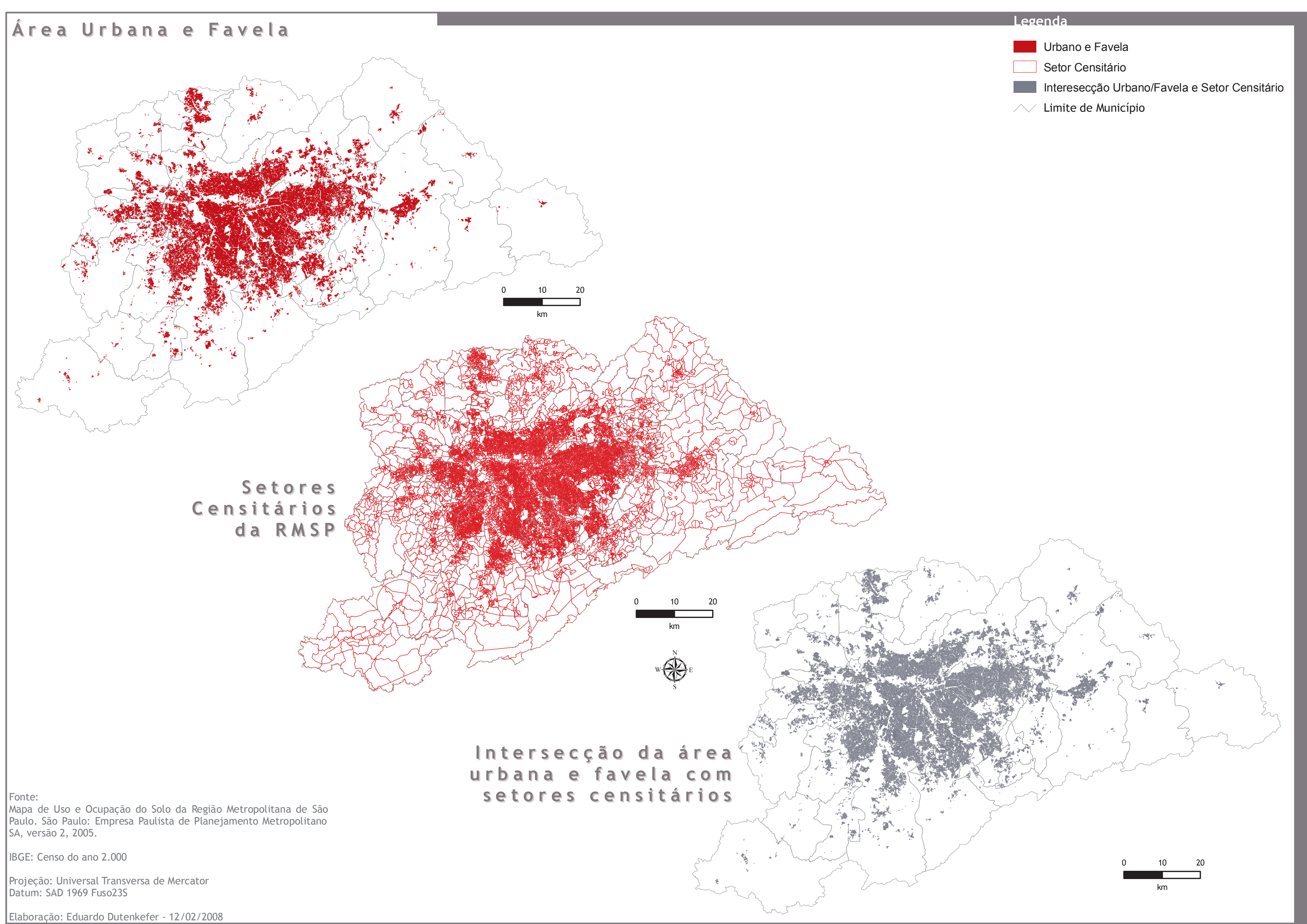




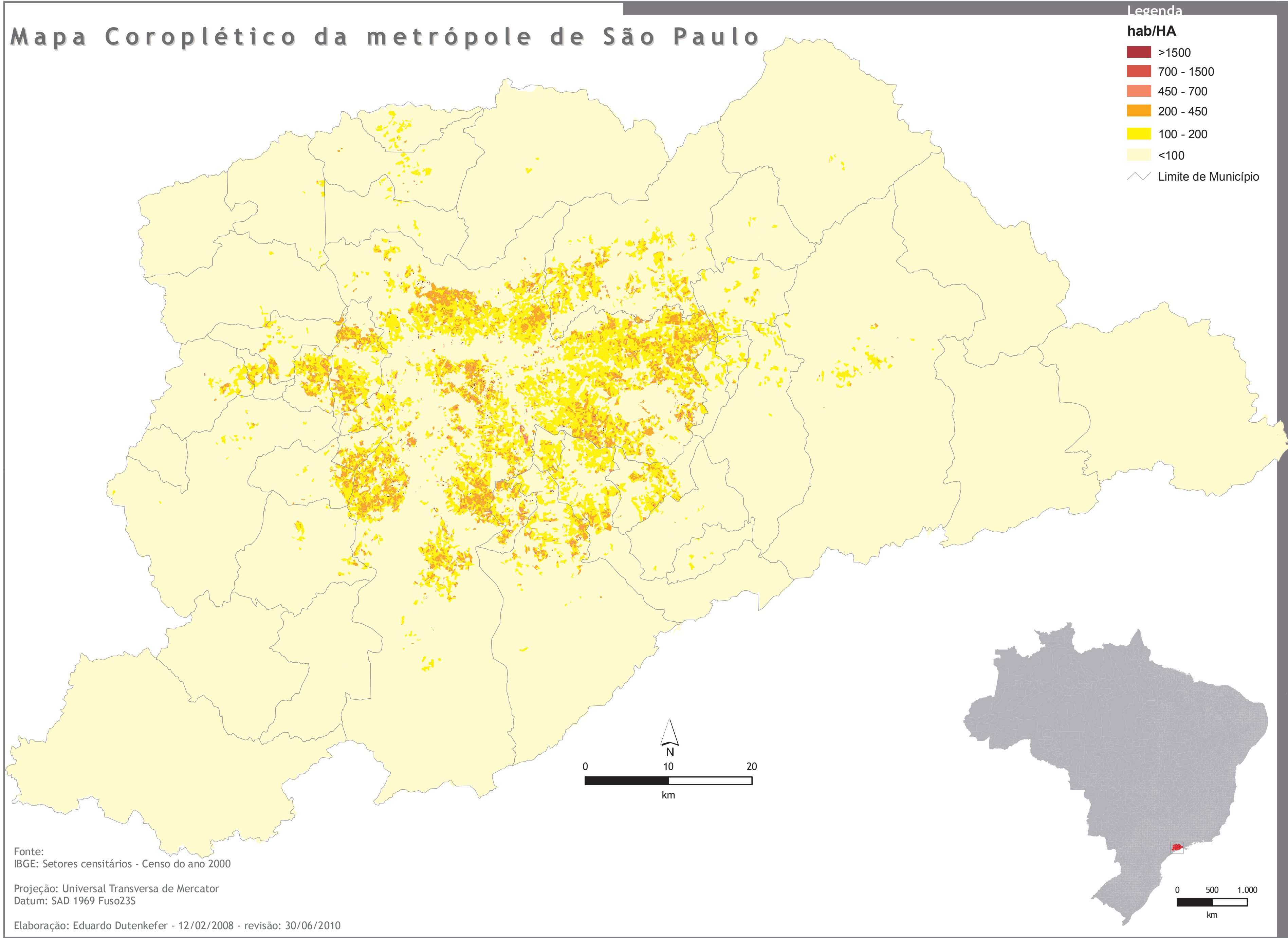




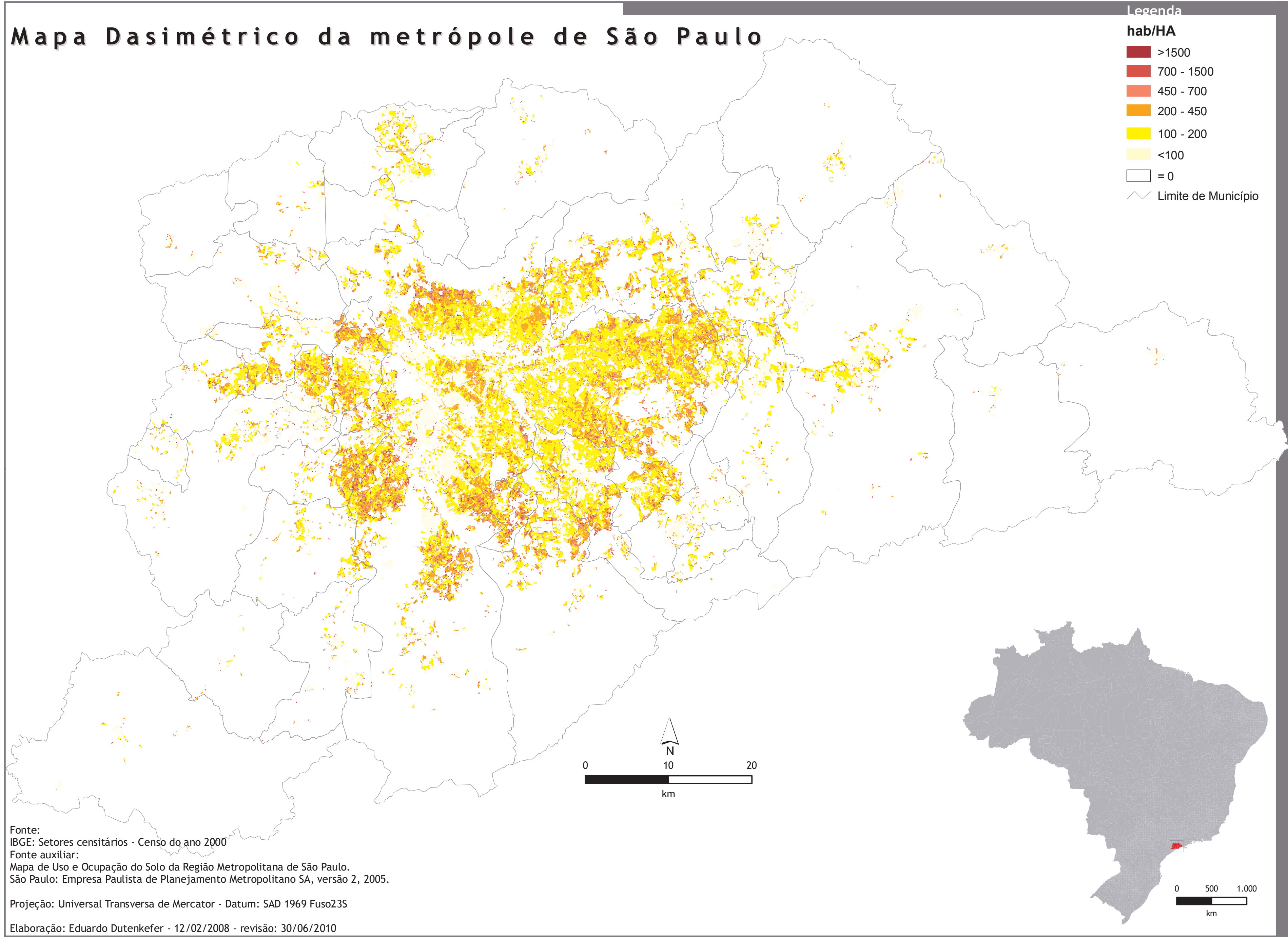




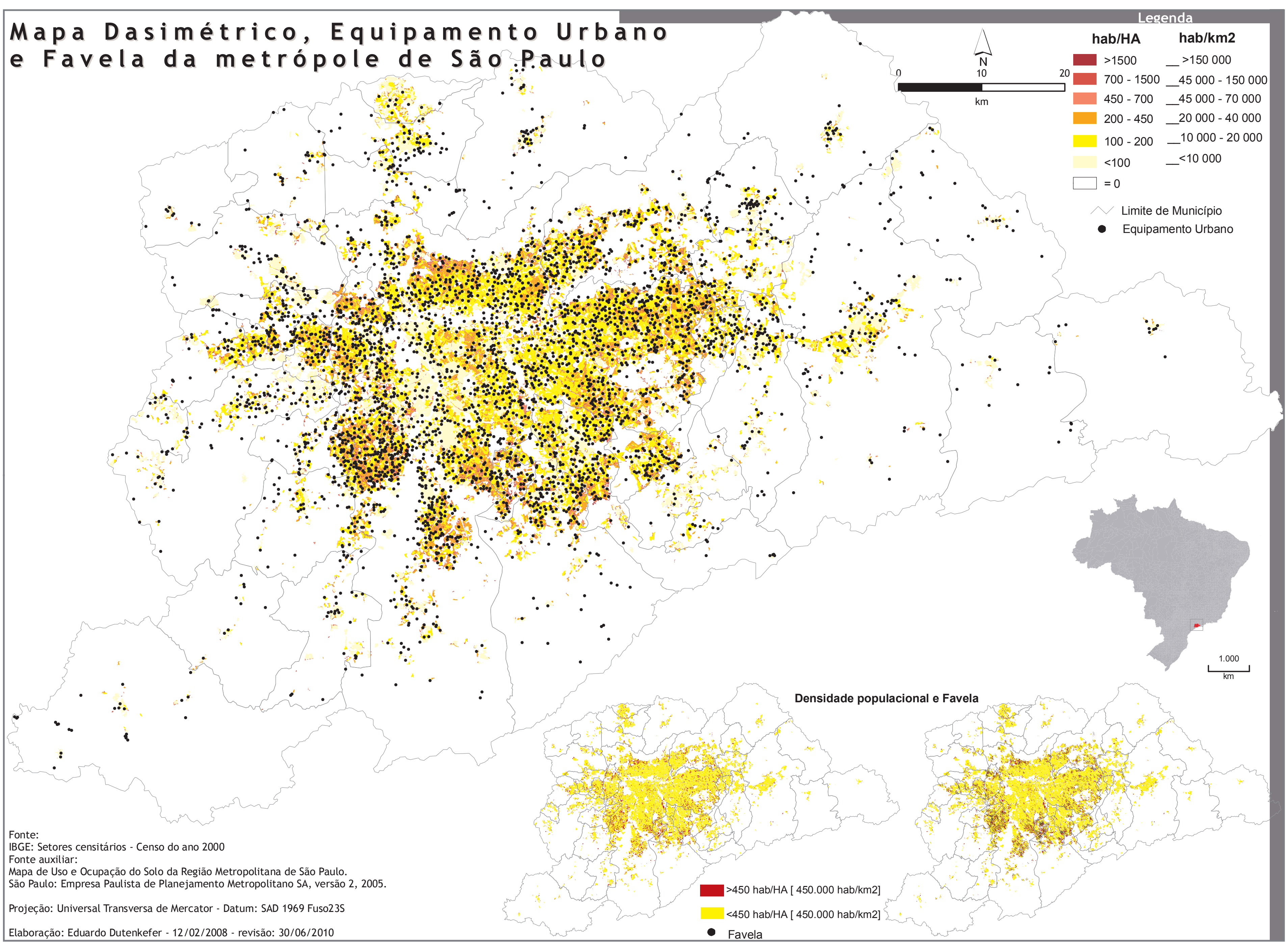




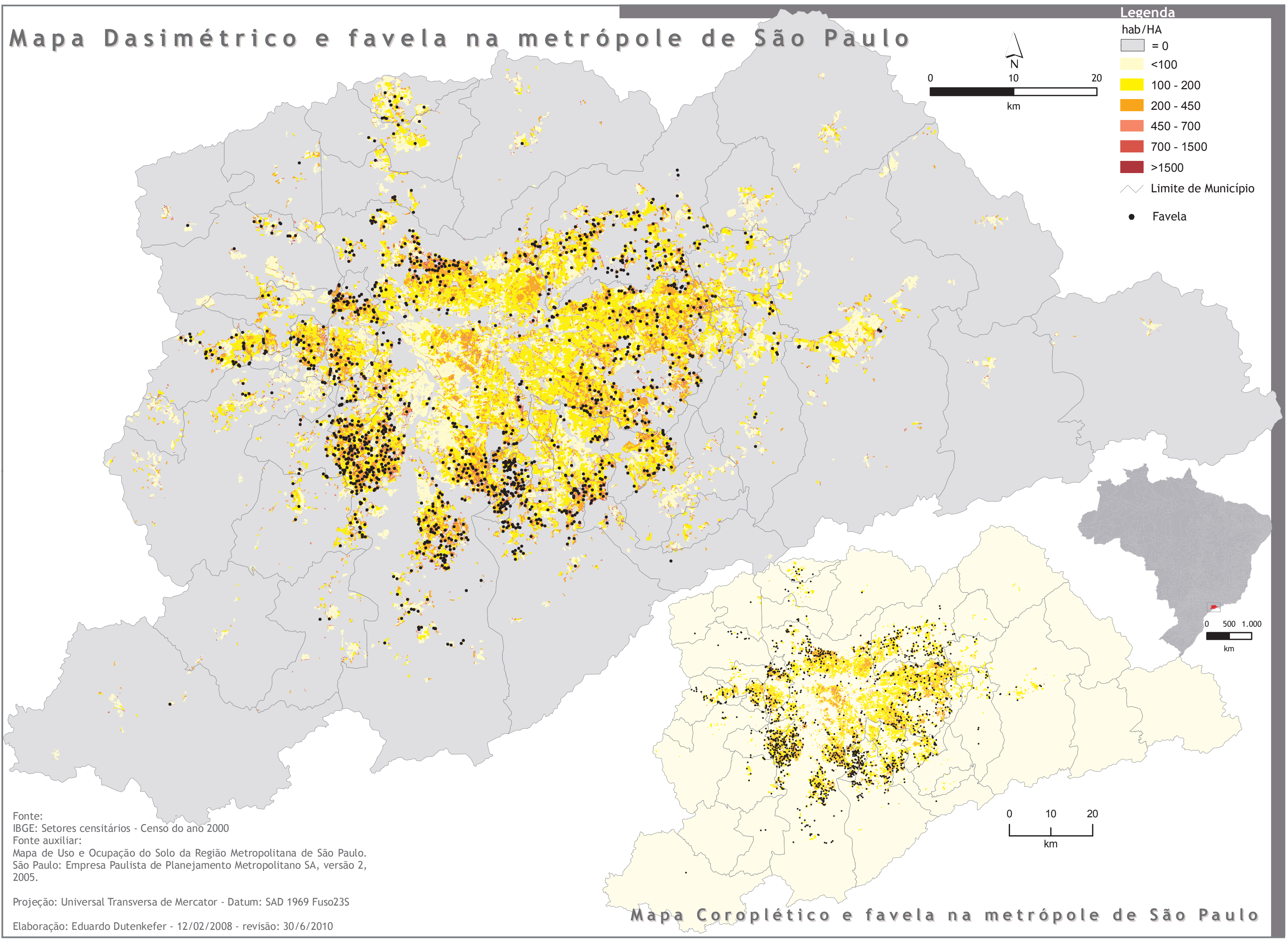




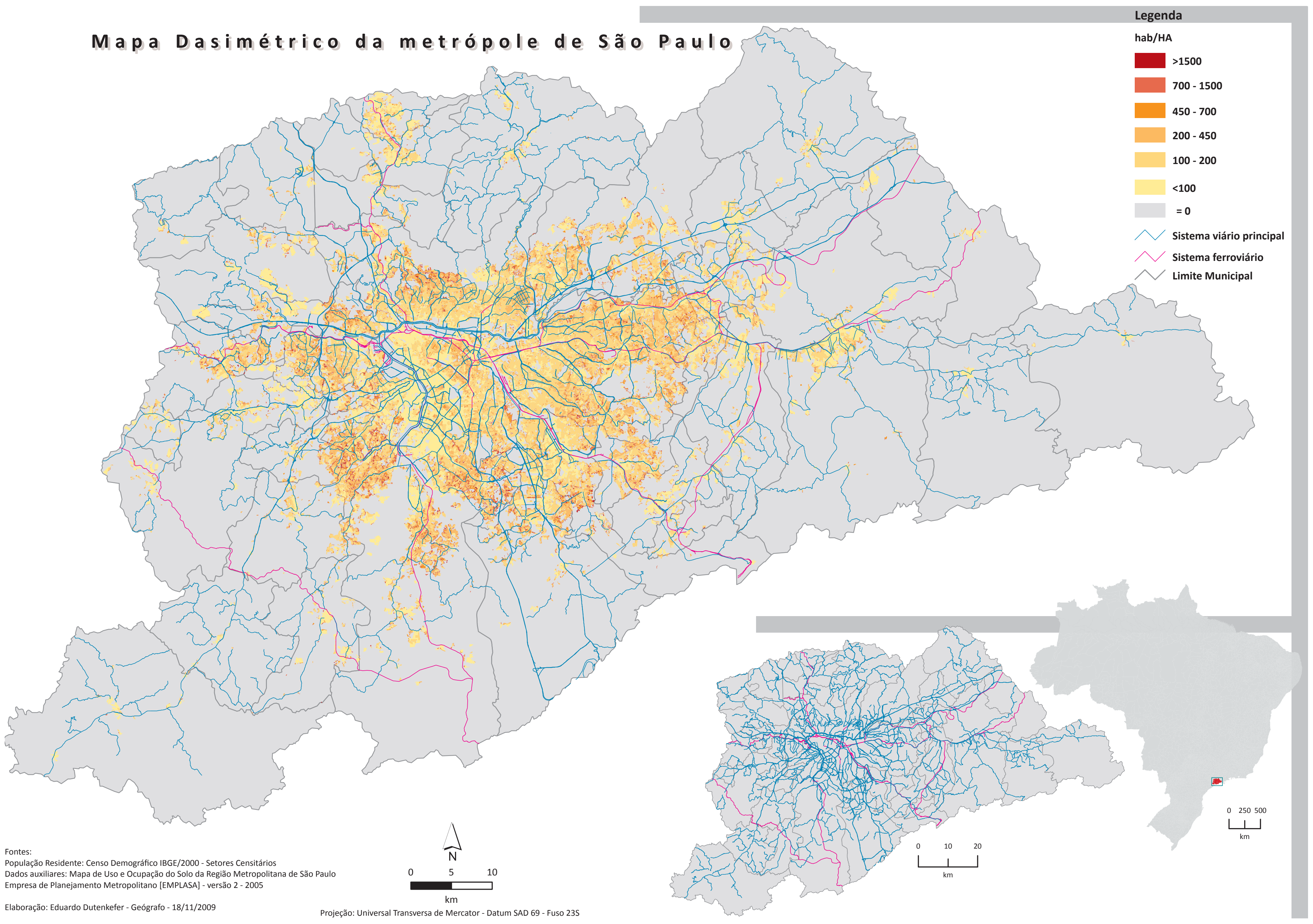




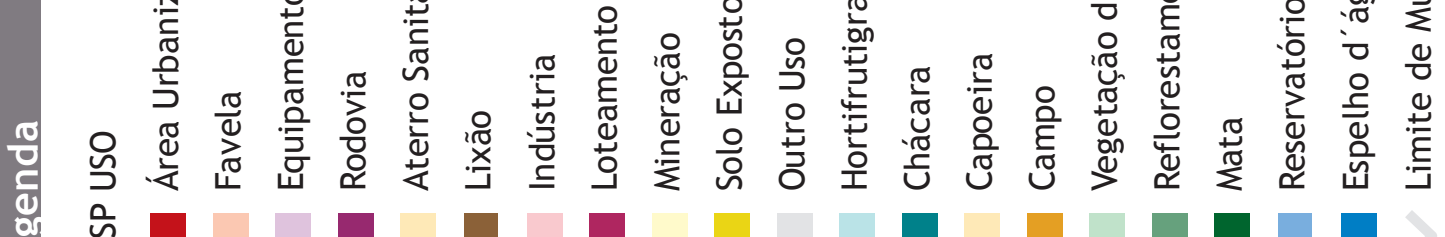

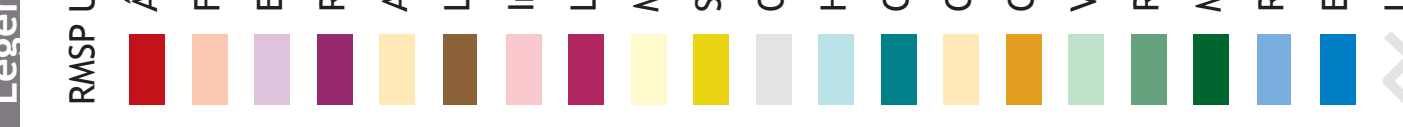

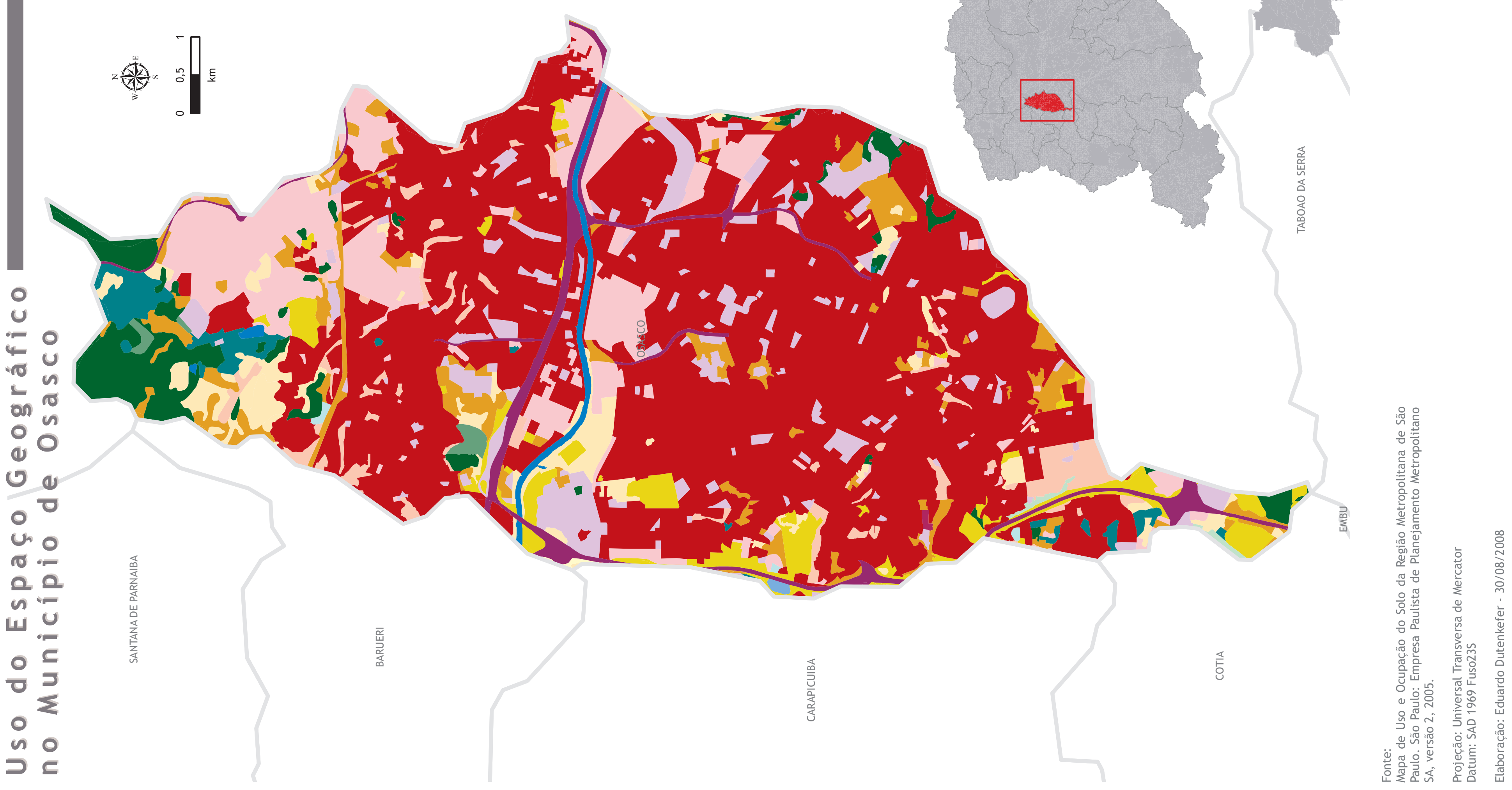




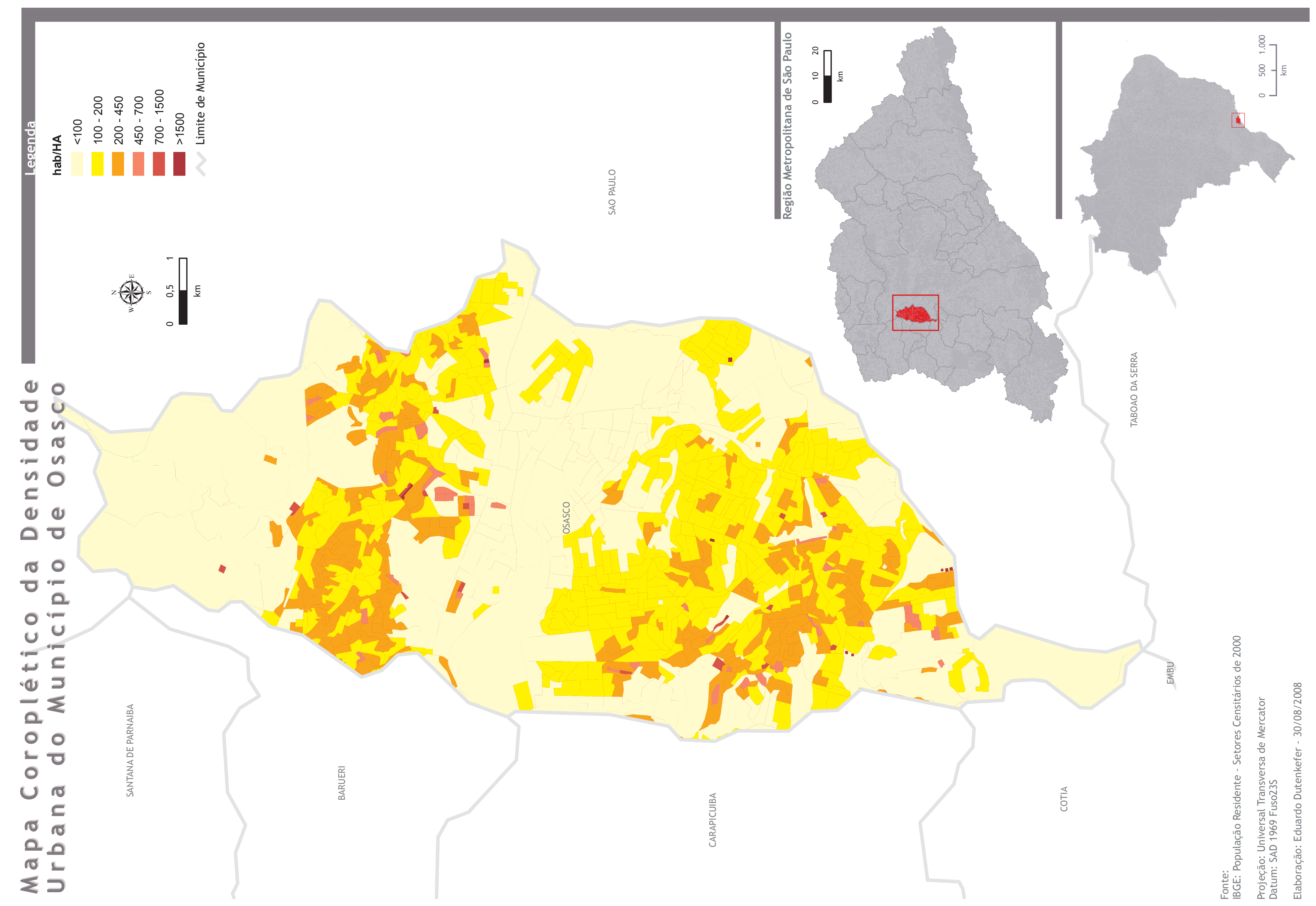




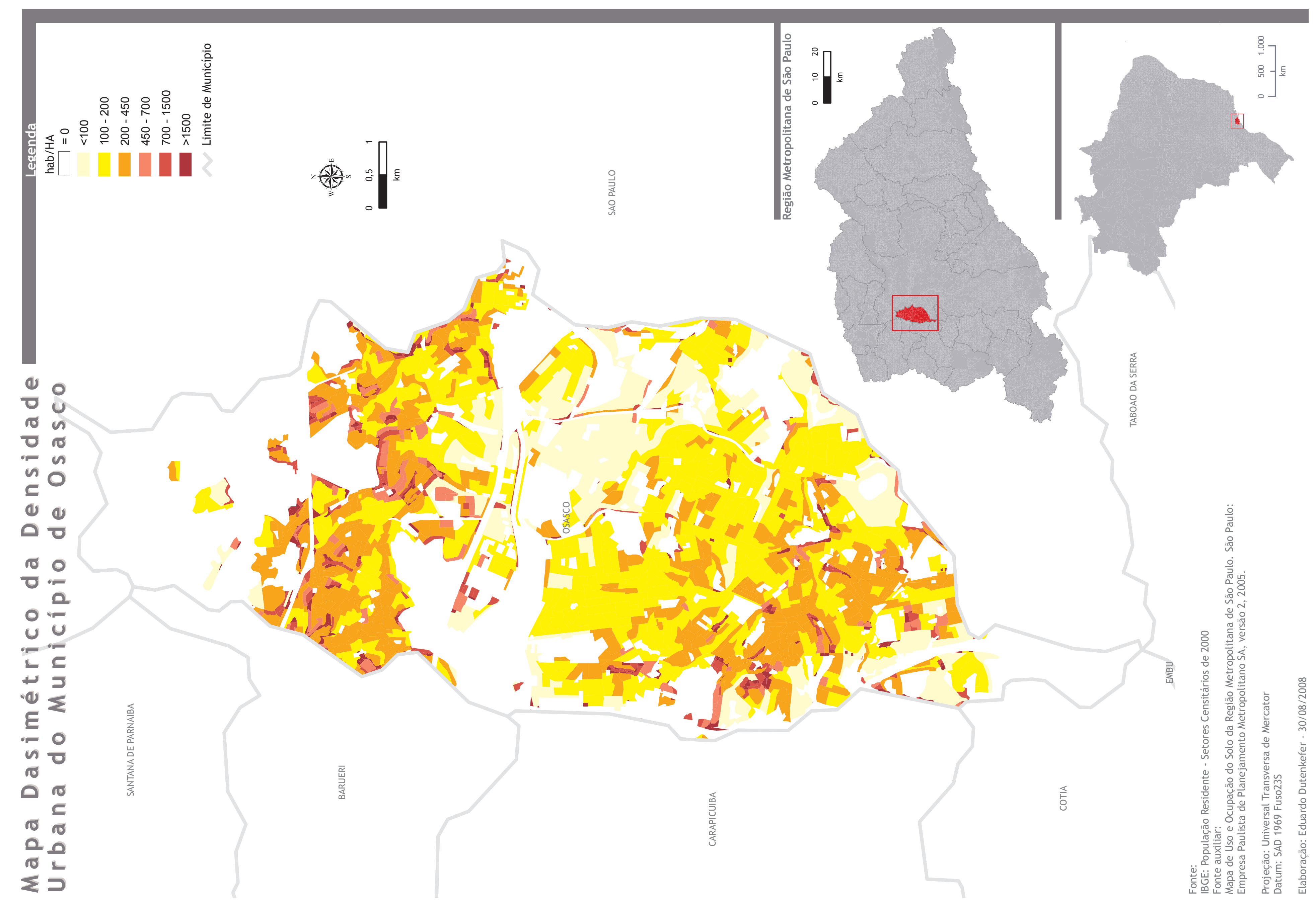




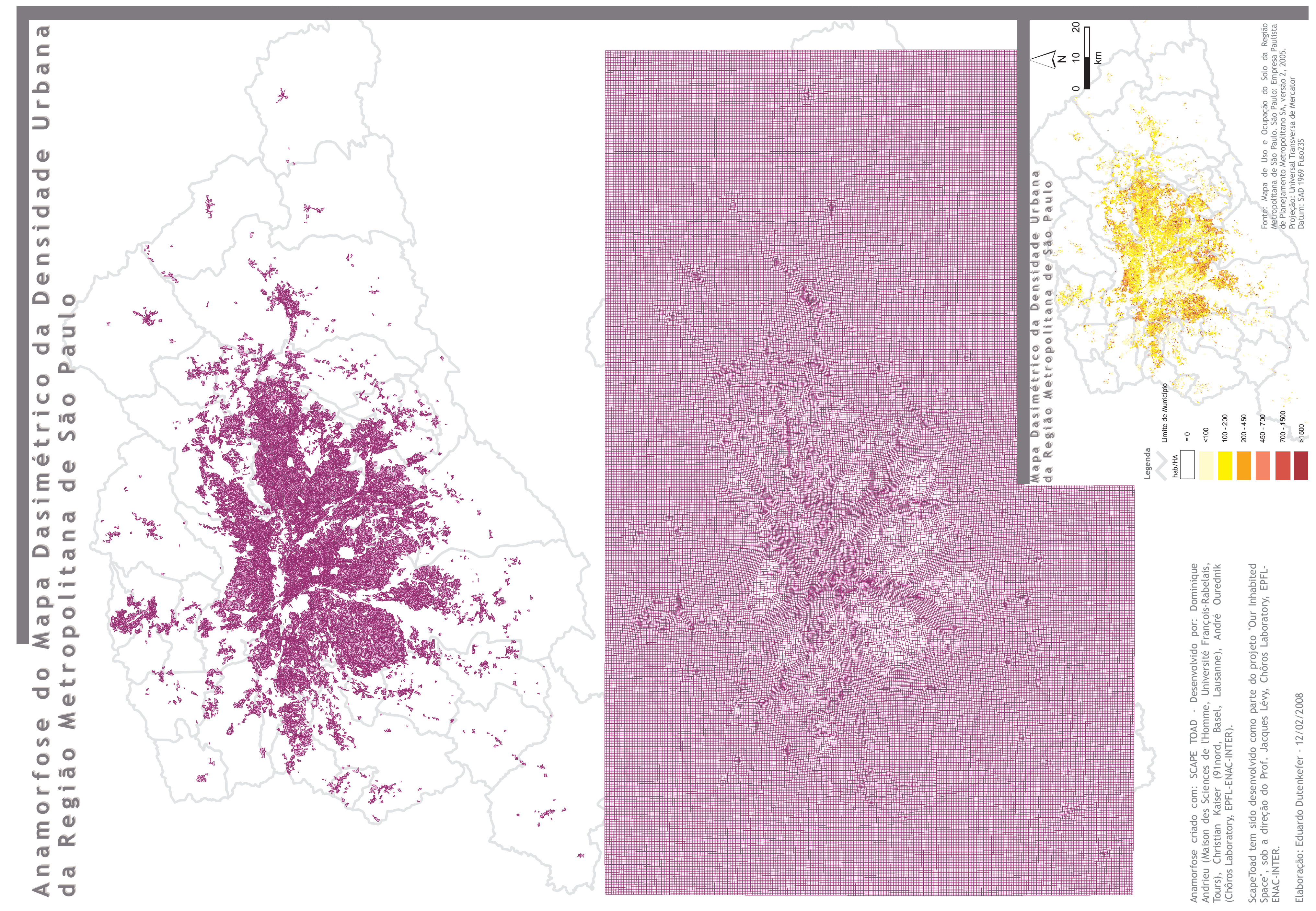




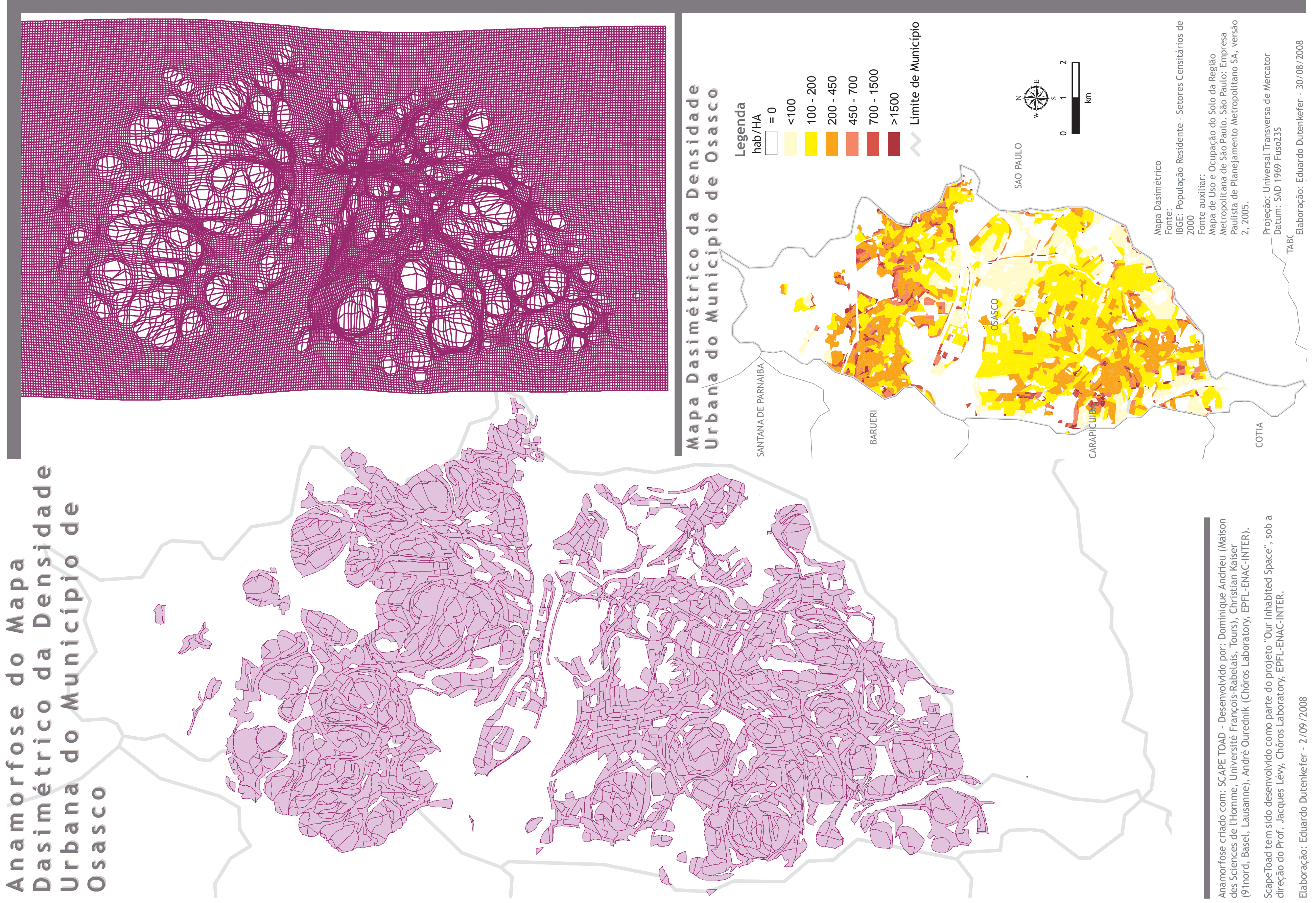

